D'OE/NASA/0291-1

NASA CR-168203

ADL 88036

\title{
New Applications for Phosphoric Acid Fuel Cells
}

R. Peter Stickles and C. Thomas Breuer

Arthur D. Little, Inc.

November 1983

Prepared for

NATIONAL AERONAUTICS AND SPACE ADMINISTRATION

Lewis Research Center

Under Contract DEN 3-291

for

U.S. DEPARTMENT OF ENERGY

Fossil Energy

Office of Coal Utilization and Extraction 


\section{DISCLAIMER}

This report was prepared as an account of work sponsored by an agency of the United States Government. Neither the United States Government nor any agency thereof, nor any of their employees, makes any warranty, express or implied, or assumes any legal liability or responsibility for the accuracy, completeness, or usefulness of any information, apparatus, product, or process disclosed, or represents that its use would not infringe privately owned rights. Reference herein to any specific commercial product, process, or service by trade name, trademark, manufacturer, or otherwise, does not necessarily constitute or imply its endorsement, recommendation, or favoring by the United States Government or any agency thereof. The views and opınions of authors expressed herein do not necessarily state or reflect those of the United States Government or any agency thereof:

Printed in the United States of America

Available from

National Technical Information Service

U.S. Department of Commerce

5285 Port Royal Road

Springfield, VA 22161

NTIS price codes 1

Printed copy: A10

Microfiche copy: A01

1Codes are used for pricing all publications. The code is determined by the number of pages in the publication. Information pertaining to the pricing codes can be found in the current issues of the following publications, which are generally available in most libraries: Energy Research Abstracts (ERA), Government Reports Announcements and Index (GRA and I); Scientific and Technical Abstract Reports (STAR), and publication, NTIS-PR-360 available from NTIS at the above address. 
DOE/NASA/0291-1

NASA CR-168203

ADL 88036

\section{New Applications for Phosphoric Acid Fuel Cells}

R. Peter Stickles and C. Thomas Breuer

Arthur D. Little, Inc.

Cambridge, Massachusetts 02140

November 1983

Prepared for

National Aeronautics and Space Administration

Lewis Research Center

Cleveland, Ohio 44135

Under Contract DEN 3-291

for

U.S. DEPARTMENT OF ENERGY

Fossil Energy

Office of Coal Utilization and Extraction

Washington, D.C. 20545

Under Interagency Agreement DE-Al21-80ET17088 
$\underline{\text { Page }}$

1.0 EXECUTIVE SUMMARY

$1-1$

1.1 INTRODUCTION

$1-1$

1.2 HARDWARE DATA BASE DEVELOPMENT

$1-1$

1.3 IDENTIFICATION OF POTENTIAL PAFC APPLICATIONS

$1-2$

1.4 TECHNICAL EVALUATION

1.5 ECONOMIC EVALUATION

$1-4$

$1-6$

1.5.1 Application Selection

$1-6$

1.5.2 Market Evaluations

1.5.3 Capital Costs

1.5.4 Annualized Life-Cycle Costs

$1-6$

$1-7$

$1-11$

1.6 CONCLUSIONS

$1-11$

1.6.1 Merits \& Shortcomings of Phosphoric Acid Cells 1-13

1.6.2 Specific Applications

$1-13$

2.0 INTRODUCTION

$2-1$

3.0 COMPARATIVE POWER SYSTEM HARDWARE DATA BASE 3- 1

3.1 INTRODUCTION

3- 1

3.2 PHOSPHORIC ACID FUEL CELL DATA

3- 1

3.2.1 Organization

3- 1

3.2.2 Technical Premises

3.2.3 Results and Discussion

$3-3$

3- 4

3.2.3.1 Fúels

3.2.3.2 Fuel Storage

3- 4

3.2.3.3 Oxidant Storage

$3-10$

$3-10$

3.2.3.4 Fuel Processors

$3-17$

3.2.3.5 Power Section

$3-22$

3.2.3.6 Power Processor/Motor

$3-23$

3.2.3.7 Heat Recovery

$3-25$

3.2.4 Assembly of Complete Fuel Cell Power System 3-29

3.3 CONVENTIONAL POWER SYSTEMS 3-29

3.3.1 Systems Considered 3-29

3.3.2 Premises of Data Development 3-32

3.3.3 Results 3-32 
TABLE OF CONTENTS Continued

3.4 COMPARISON OF PAFC AND CONVENTIONAL POWER SYSTEMS 3-34

3.4.1 Use of the Hardware Data Base 3-34

3.4.2 Fuel Use and Fuel Efficiency 3-35

3.4.3 Other Potential Advantages 3-38

CHAPTER 3 REFERENCES R- I

4.0 APPLICATION IDENTIFICATION AND CLASSIFICATION 4- 1

4.1 APPLICATION CLASSES CONSIDERED 4- 1

4.2 APPLICATIONS LIST GENERATION . . . 4- 1

4.2.1 Brainstorming Meetings 4- 3

4.2.1.1 Remote Power Applications 4- 3

4.2.1.2 Other Oil and Gas Industry and
Related Applications

4.2.1.3 Food and Agribusiness 4- 5

4.2.1.4 Transportation 4- 5

4.2.1.5 Mining 4-8

4.2.2 Literature Search 4-8

4.2 .3 Other Sources 4-10

4.3 APPLICATIONS LIST $\quad 4-10$

4.4 APPLICATION CLASSIFICATION $\quad 4-1.0$

5.0 TECHNICAL ANALYSIS OF APPLICATIONS $5-1$

5.1 SELECTION OF CANDIDATE APPLICATIONS $5-1$

5.1.1 Comparative Analysis $5-1$

5.1.2 Application Selection $5-4$

5.2 THIRD WORLD ETHANOL PLANT POWER . 5- 8

5.3 LONG HAUL TRUCK TRACTOR POWER SYSTEM $5-12$

$\begin{array}{ll}5.4 & \text { URBAN TRANSIT COACH } \\ 5-15\end{array}$

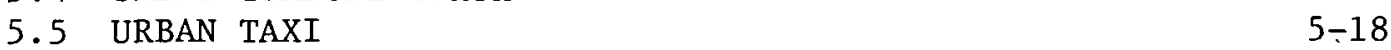

5.6 POWER FOR MOBILE REFRIGERATION $5-21$

5.7 ARCTIC VILLAGE POWER SYSTEM . $5-23$

5.8 RAILROAD LOCOMOTIVE

5.9 TOWBOAT . 5-28

5.10 MINE LOCOMOTIVE $3-30$

5.11 FORKLIFT TRUCK $\quad 5-34$

5.12 ROBOTIC SUBMERSIBLE 5-36 
TABLE OF CONTENTS Continued

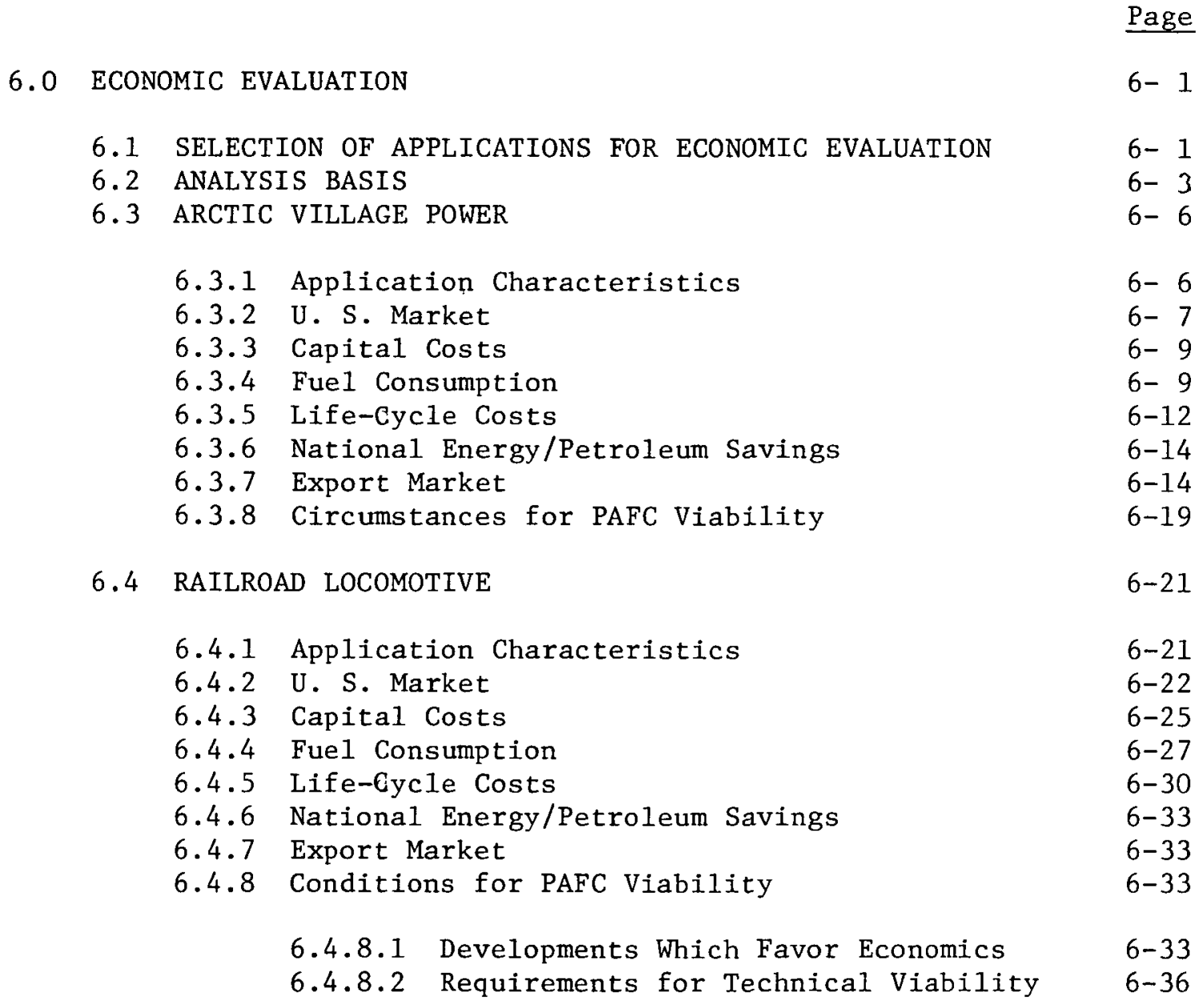

$\begin{array}{ll}6.5 & \text { MINE LOCOMOTIVE }\end{array}$

6.5.1 Application Characteristics 6-37

6.5.2 U. S. Market 6-39

6.5.3 Capital Costs 6-40

6.5.4 Fue1/Energy Consumption 6-40

6.5.5 Life-Cycle Costs 6-43

6.5.6 National Energy/Petroleum Savings 6-46

6.5.7 Export Market 6-46

6.5.8 Circumstances for PAFC Viability 6-46

6.5.8.1 Developments Which Favor Economics 6-46

6.5.8.2 Requirements for Technical Viability 6-49 
6.6 ROBOTIC SUBMERSIBLE POWER 6-49

6.6.1 App1ication Characteristics 6-49

6.6.2 U. S. and Export Market 6-51

6.6.3 Capital Costs 6-51

6.6.4 Fuel Consumption 6-53

6.6.5 Life-Cycle Costs 6-55

6.6.6 National Energy/Petroleum Savings 6-59

6.6.7 Circumstances for PAFC Viability 6-59

6.6.7.1 Developments Which Favor Economics 6-59

6.6.7.2 Requirements for Technical Viability 6-59

CHAPTER 6 REFERENCES

R- 1

APPENDICES 


\subsection{EXECUTIVE SUMMARY}

\subsection{INTRODUCTION}

Arthur D. Little undertook a study of phosphoric acid fuel cell applications for the NASA Lewis Research Center. The purpose of this study is to survey all other possible applications, identifying the most promising, and begin analysis of those most promising applications. This report presents our findings.

In the past numerous studies have been conducted analyzing specific preselected applications for phosphoric acid fuel cells (PAFC). Phosphoric acid fuel cell (PAFC) applications of interest here include all possibilities except:

- Large, grid connected electric utility applications;

- On-site residential/commercial/small industrial total energy system applications, such as those being evaluated in the ongoing $40 \mathrm{~kW}$ program;

- Industrial cogeneration applications in the industrialized world;

- Applications which opportunistically use available waste hydrogen;

- Space and military applications;

- Applications with power requirements small than $10 \mathrm{~kW}$.

An extensive list was developed of potential PAFC applications which fall within this study's scope. They were classified, screened for suitability of PAFC use, and the resulting list of eleven applications subjected to further technical evaluation. The best four of these were then evaluated for economic feasibility.

\subsection{HARDWARE DATA BASE DEVELOPMENT}

A data base was developed which could be used to characterize a wide variety of potentially interesting PAFC power systems. This was accomplished by dividing the overall PAFC system into four subsystems which can be decoupled one from another for purposes of analysis, with each subsystem readily characterizable in terms of one input and one output. The subsystems are:

- Fuel storage. This system stores fuel for feed to the fuel processor (or to the power section itself if pure hydrogen is used). 
- A fuel processor. This section takes a hydrocarbon or alcohol fuel and processes it into a hydrogen rich gas for use by the power section.

- The power section. This consists of the fuel cells themselves, the air circulation system, and limited additional auxiliaries.

- The power processor. This system takes the raw power produced by the fuel cell and converts it into three-phase $A C$, regulated $D C$, or shaft power via electric motor, as required.

A fuel cell power system is defined as a coupling of a power processor (if needed), a power section, a fuel processor (if needed), a fuel storage system, and a choice of fuel. It is sized in terms of the net power output. On this basis, total system weight, volume, capital costs, and efficiency are calculated.

For purposes of comparison, analogous data were developed on complete conventional power systems. Systems characterized included:

- Diesel engines, with and without generators;

- Gasoline engines without generators;

- Gas turbines, with and without generators;

- Lead acid batteries.

Table 1.1 provides example Hardware Data Base output for three possible power systems for generation of $1,000 \mathrm{~kW}$ of three-phase AC power. These data are appropriate to long-lived, stationary applications. Weights, volumes, and capital costs include skid mounting and custom engineered installation into the user's facility. Thus, the absolute estimates of weights, volumes, and capital costs may be inappropriate to other classes of applications, such as vehicular applications. In all classes of applications, however, it is expected that the numeric differences between the weights, volumes, and capital costs projected for the conventional systems and for the fuel cells are valid.

\subsection{IDENTIFICATION OF POTENTIAL PAFC APPLICATIONS}

Investigation of new applications began with a two-step process:

- Unrestricted identification of possible applications;

- Classification of the identified applications to yield a workable number of application classes for further analysis. 


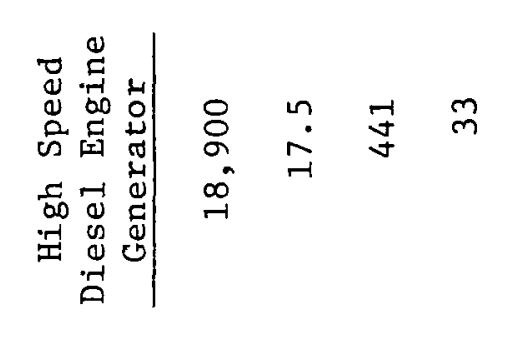

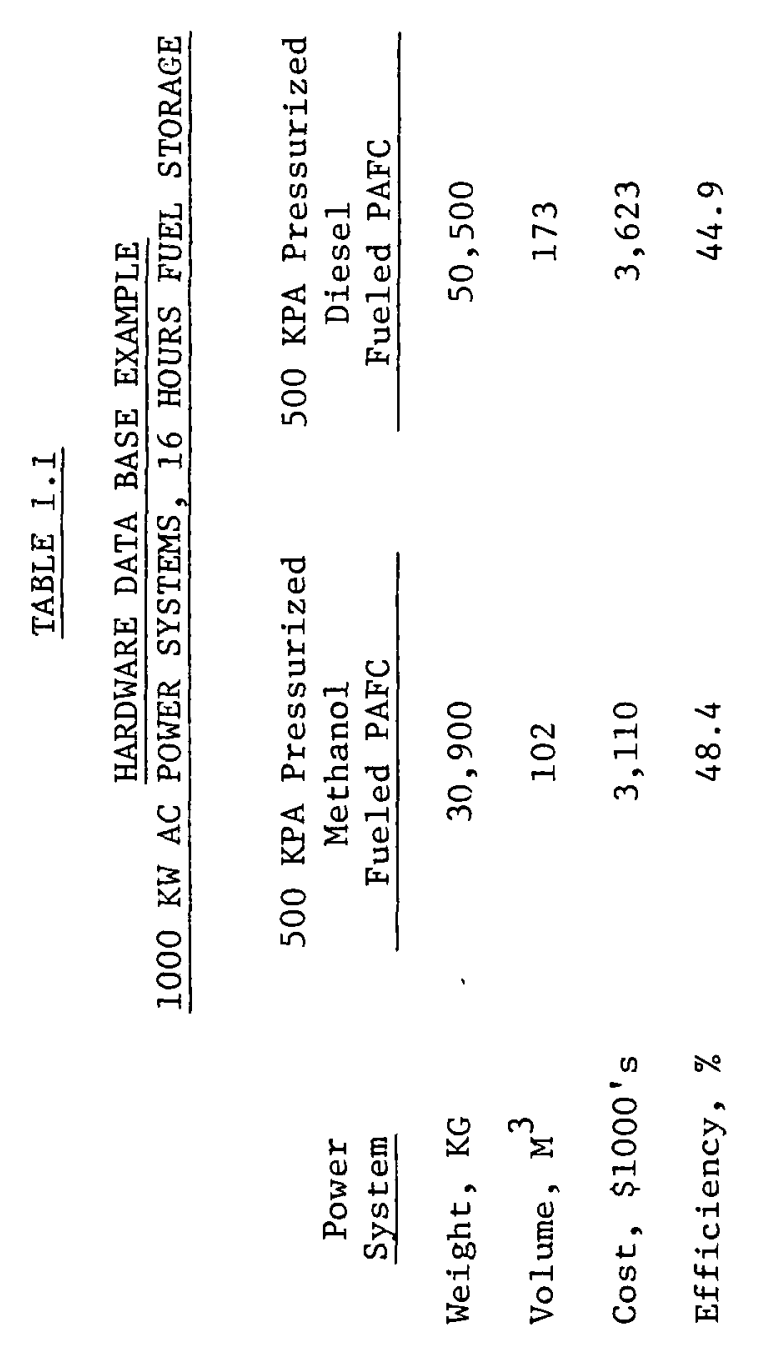


The former was essentially a brainstorming activity, limited only by the study scope previously mentioned. Application list generation was accomplished through four activities:

- Application conceptualization meetings;

- Literature search;

- Review of Arthur D. Little's study of potential stirling engine application;

- Direct contacts with equipment vendors.

As a result of these activities, a list of 64 applications in eight broad areas of commerce was produced.

As a preliminary to evaluation of possible use of PAFC in these applications, it was necessary to classify them, grouping them according to similarity in power system requirements. Then PAFC applicability could be evaluated for conformity to this set of requirements for each class, rather than for conformity to specific requirements of each individual application.

The criteria used for classification were:

- System operating life;

- System power requirement;

- Form of power needed (electrical or mechanical);

- Special needs for unattended operation or low maintenance requirements;

- Relative importance of five characteristics: 1. restriction on size or weight; 2 . high fuel efficiency; 3 . low emissions; 4. opportunities to use a solid or dirty liquid fuel; and 5 . high reliability.

\subsection{TECHNICAL EVALUATION}

The evaluation began with selection of 11 specific applications for further evaluation. Applications were selected by first comparing the relative merits of PAFC and its conventional competition in each application class. A list of classes was chosen for further evaluation based on this comparison and on a desire to evaluate a diverse list of applications. Then for each application class so chosen, a specific power system application was selected for further evaluation. The resulting list of 11 applications is shown in Table 1.2. 


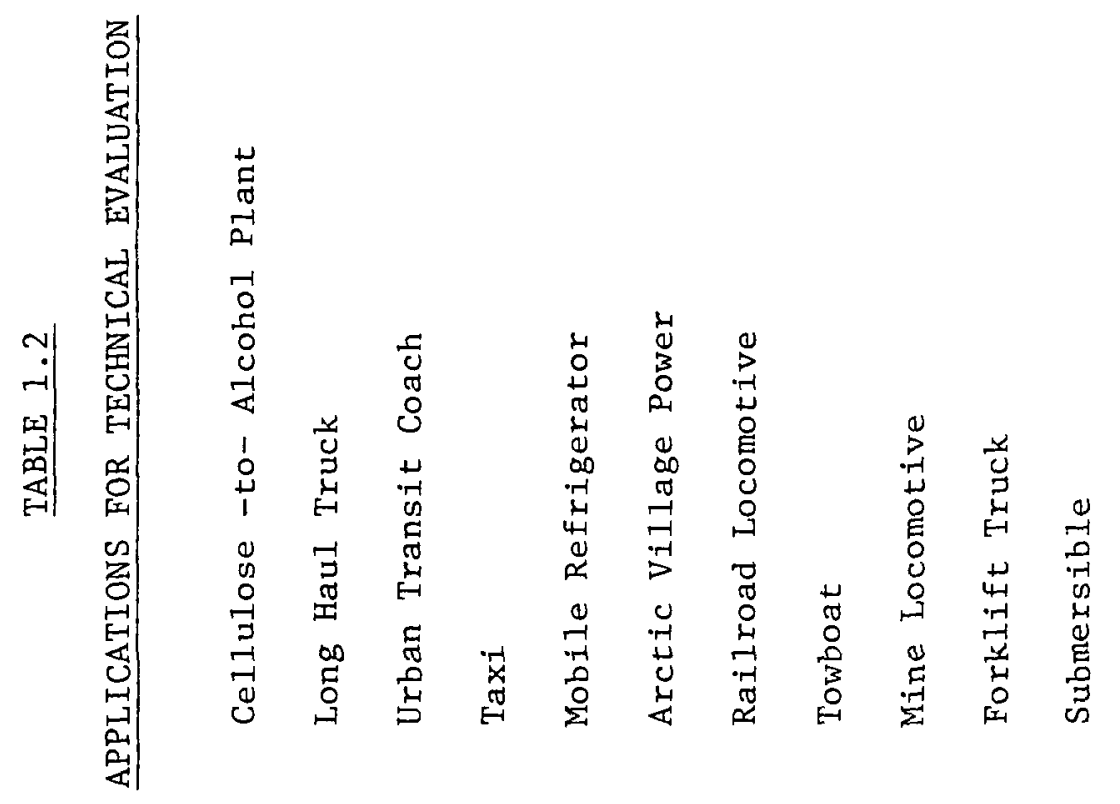

$1-5$ 
A more detailed comparative evaluation was then conducted of the conventionally used system in each of these applications and the candidate PAFC system which might be used to replace it. Criteria of principal importance were power system weight, volume, efficiency, and special advantages or disadvantages anticipated for operation in the environment of the application.

Analysis of the comparative performance of PAFC and the conventional systems in these applications indicated that the phosphoric acid fuel cell appeared to offer no meaningful technical advantage in five of the applications:

- Alcohol plant power

- Long haul trucks

- Urban transit coach

- Taxi

- Mobile refrigerator

For each of the other applications listed in Table 1.3, PAFC appeared to offer some definite technical advantage.

\subsection{ECONOMIC EVALUATION}

\subsubsection{Application Selection}

The remaining six applications were reviewed to see if any bore a strong similarity to any others in terms of the prospects for PAFC use. It was determined that such similarities were exhibited by the railroad locomotive and the tow boat and also by the mine locomotive and forklift truck. It was judged that PAFC probably enjoys a greater advantage over its conventional competition in the railroad locomotive and mine locomotive cases. Therefore, they and the Arctic village and submersible applications were chosen for economic evaluation.

\subsubsection{Market Evaluations}

Thorough economic evaluation necessarily involved the development of additional information characterizing each application and the likely power systems employed. Evaluation of learning curve related PAFC capital cost reduction, national energy savings potential, etc., required further information concerning the market for PAFC systems in each application. This information included:

- The range of operating hours experienced by units sold, with identification of a significant segment of the unit 
population which is dedicated to high duty operation, incurring attractively large numbers of operating hours each year

- Characterization of this high duty operation, i.e., operating hours per year, load factor while operating, etc.

- Number of annual unit sales which would be dedicated to such high duty operation

- A representative unit size for high duty application

- Resulting megawatts of PAFC capacity accountable annually to sale for high duty application.

This information is summarized in Tables 1.3 and 1.4 .

\subsubsection{Capital Costs}

Capital costs for candidate power systems for each application were estimated according to a two-step process:

- Develop costs from the Hardware Data Base;

- Adjust phosphoric acid fuel cell system costs for learning curve effects.

The first step involved simple use of the Hardware Data Base as described above to project the capital costs of the candidate power systems based on the required quantity and form of power output. The appropriate degree of PAFC system cost reduction was estimated for each application considered. In each case, learning curve cost reduction effects were projected based on the assumption that that application constitutes the only market for phosphoric acid fuel cells.

Table 1.5 presents the resulting system capital costs. The four applications studied in detail display the full range of capital cost reduction effects. Reductions are insignificant for the submersible with its tiny market, while they exceed $50 \%$ for the railroad locomotive with its large market and attendant high production rates. 


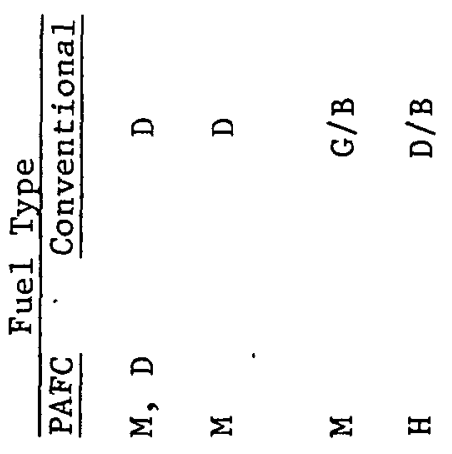

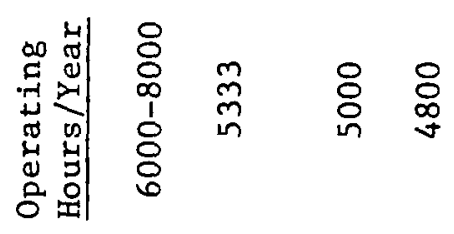

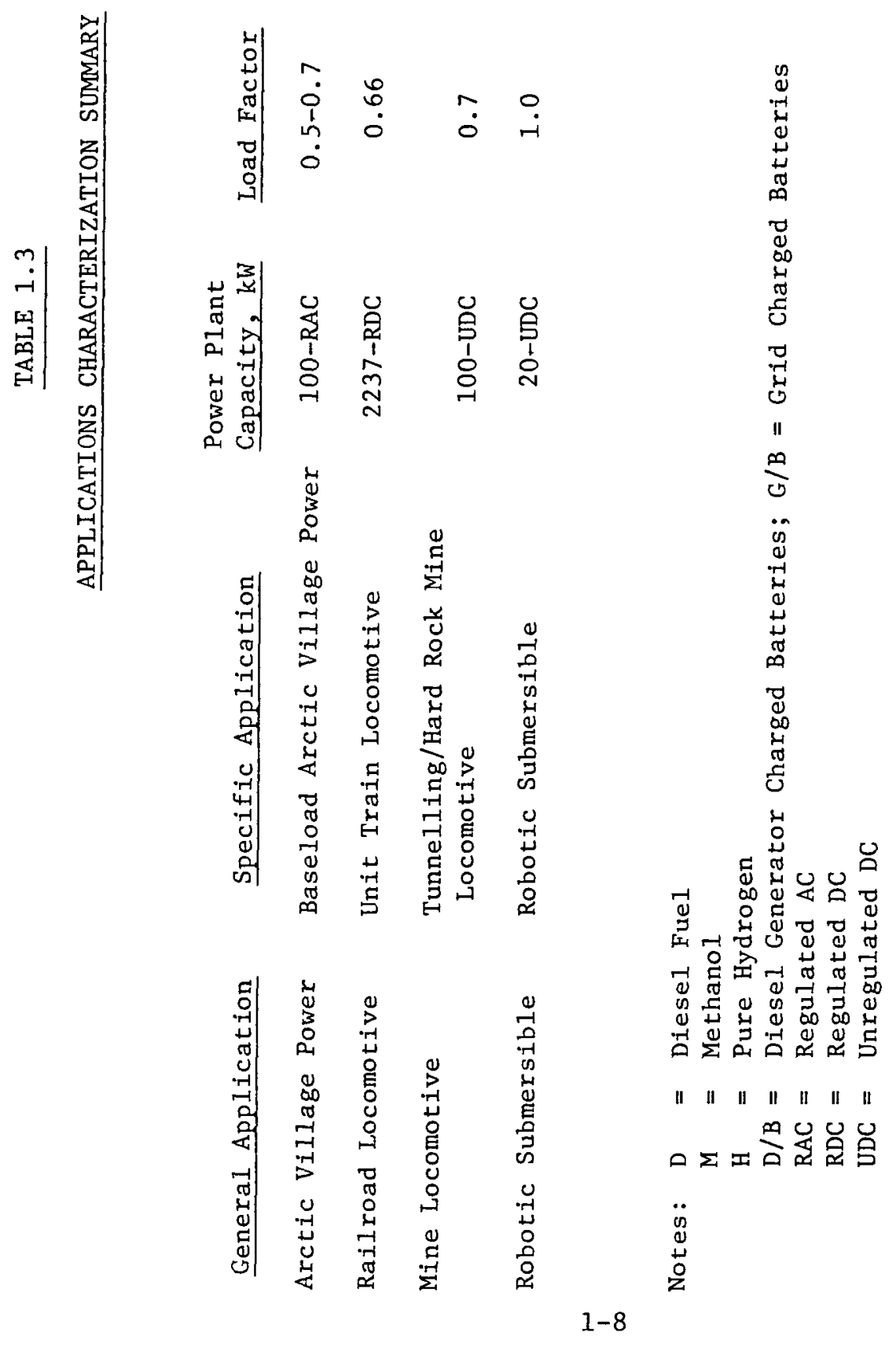




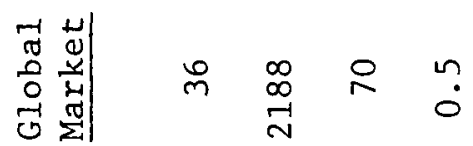

$$
\begin{aligned}
& \text { r. }
\end{aligned}
$$




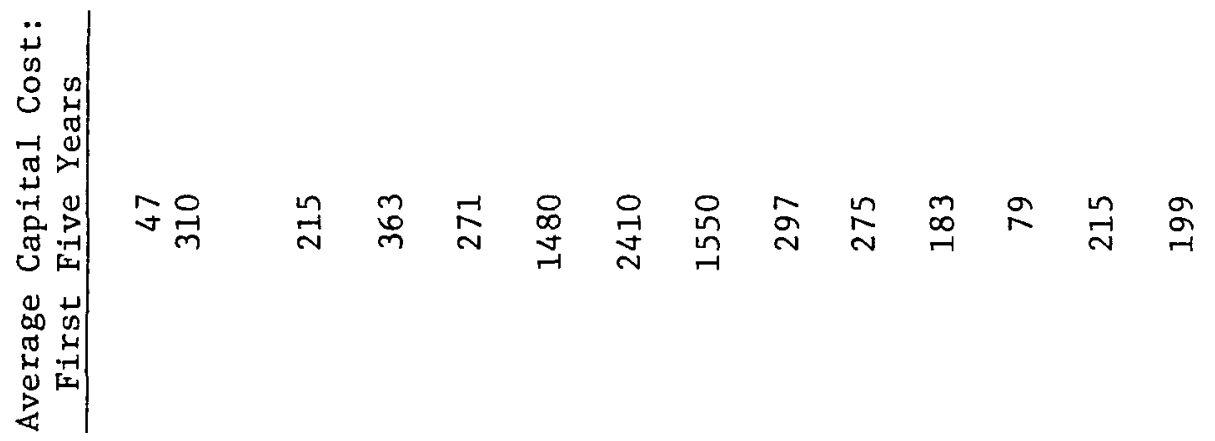

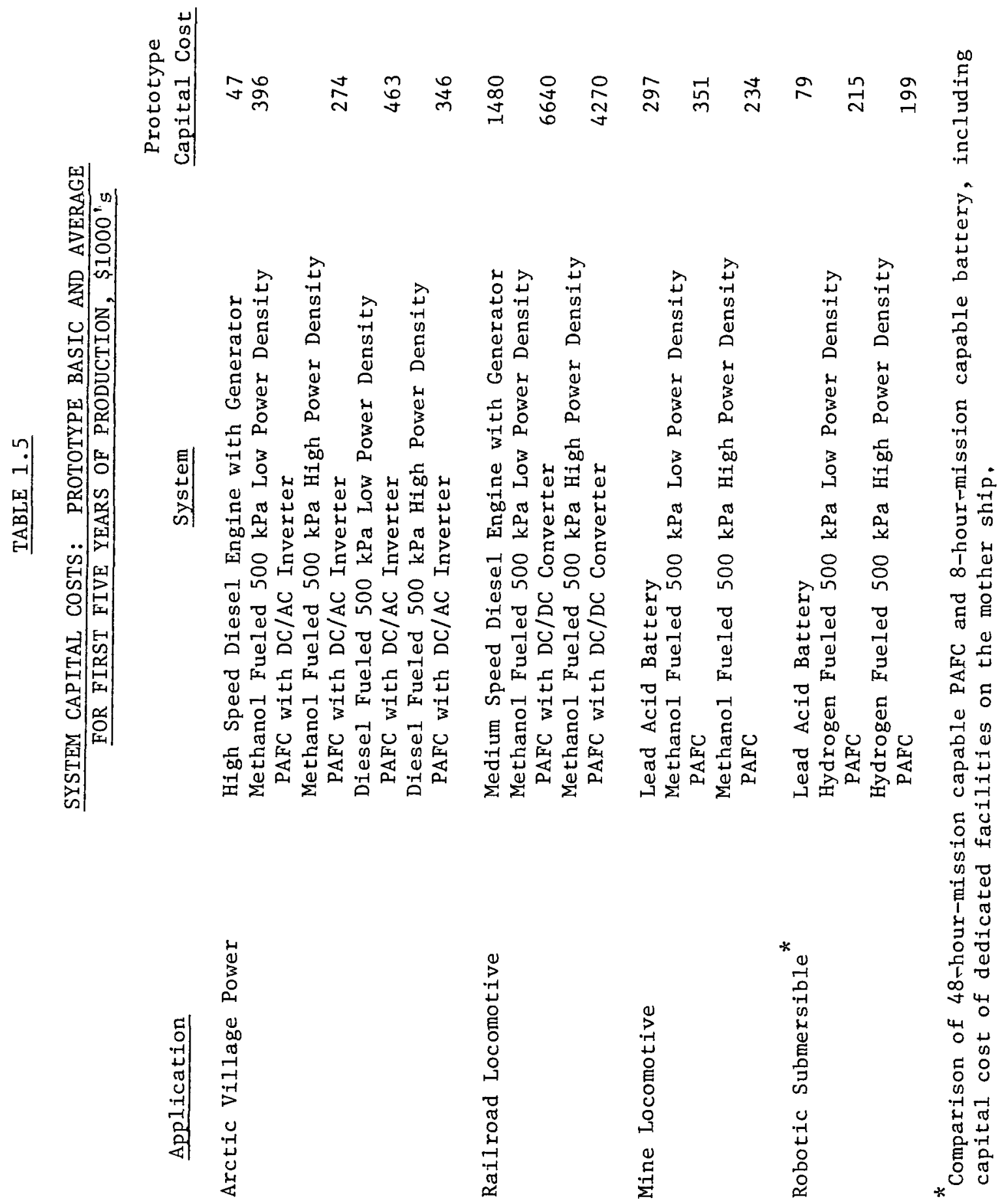

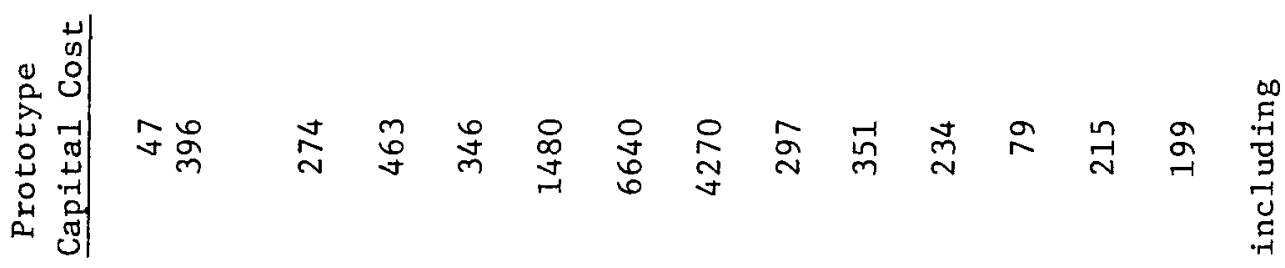




\subsubsection{Annualized Life-Cycle Costs}

Development of annualized Iife-cycle costs was necessarily application-specific, including accounting of energy costs as would be incurred in the application, costs of general system operation and maintenance, cost of replacement cell stacks where needed, and assessment of capital charges. The resulting annualized life-cycle costs are displayed for each application in Table 1.6.

The annualized life-cycle cost comparisons of fuel cells and diesel systems for Arctic villages show a small advantage for the diesel system. However, this apparent margin falls within the error margins inevitable in this analysis, as do margins displayed in favor of PAFC for the other applications listed.

Comparison of life-cycle costs for the railroad locomotive appear to show a total cost advantage for PAFC. This results from the very substantial reductions in capital costs expected to follow from the large scale production of PAFC to serve this large market and from large annual fuel savings.

Comparison of life-cycle costs of the PAFC and rechargeable battery systems for the mine locomotive also shows a cost edge for PAFC. The apparent cost advantage displayed in this application is particularly interesting, because it does not depend on large learning curve related capital cost reduction or large fuel cost savings such as is required in the locomotive case; near parity exists in every cost category. Most important in this application it is likely that PAFC offers substantial additional advantages related to utility of operation which are not quantified in this simple life-cycle cost comparison. These are expected to accrue by reducing loss of work time connected with battery recharge and in-operation battery failure.

On the robotic submersible, PAFC again appears to offer an economic advantage over the rechargeable battery, despite higher annualized life-cycle costs. This advantage results entirely from increased utility of operation, with the fuel cell based system providing more useful hours of work on the ocean floor per unit time spent at sea by the submersible, its mother ship, and support crew.

\subsection{CONCLUSIONS}

Two sets of general conclusions can be drawn from this study. The first set concerns the relative merits and deficiencies of the phosphoric acid fuel cell vis-a-vis alternate power systems. The second concerns the particular suitability or unsuitability of PAFC to general classes of applications. 


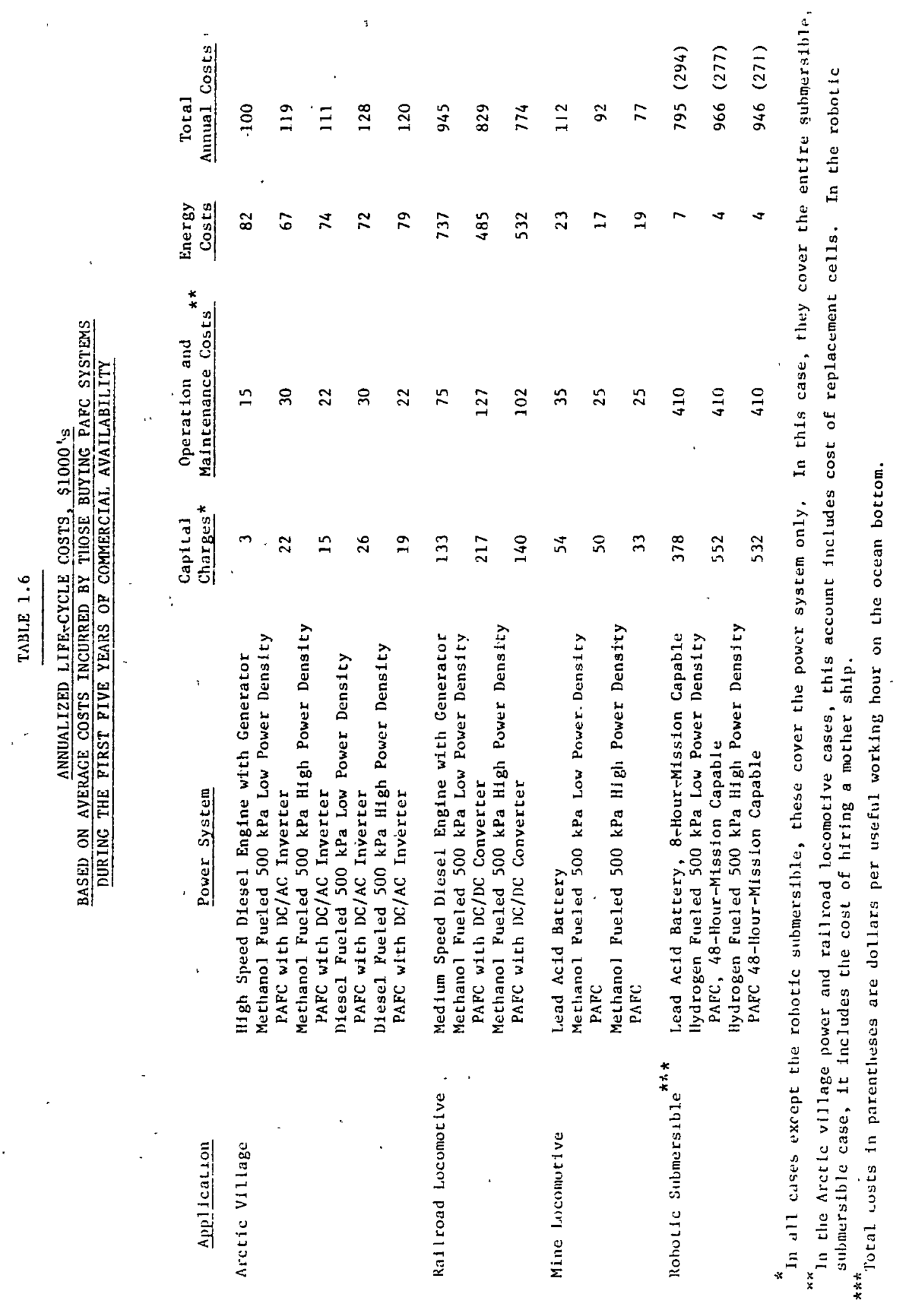




\subsubsection{Merits \& Shortcomings of Phosphoric Acid Cells}

Five conclusions are developed on the comparative advantages and disadvantages of PAFC vis-a-vis conventional alternatives:

- In situations where it is feasible to provide the necessary power via a steam cycle, based on a solid fuel fired boiler, this is likely to be the preferred system. Under these circumstances, the modest energy efficiency advantage of the fuel cell can seldom overcome the capability of the steam system to use a much less expensive fuel.

- In most other applications of concern in this study, the principal obstacle to fuel cell use is capital cost. PAFC capital costs are higher than those of conventional systems, and must be reduced substantially for the fuel cell to be competitive in most applications. Careful investigation can, however, identify applications which might be economically served by fuel cell systems whose capital costs do substantially exceed those of the conventionally used systems.

- Current phosphoric acid fuel cell systems probably cannot compete with internal combustion engines in applications where weight and volume are of substantial importance. This includes most light duty vehicles, whose overall fuel efficiency will be reduced significantly by the fuel cell's added weight.

- The fuel cell's key advantage over internal combustion engines is fuel efficiency. This can yield substantial savings in applications where high load factors are achieved for large numbers of operating hours per year.

- Industrial practice is to substitute batteries for internal combustion engines in applications where the fuel cell's cleanliness was expected to offer a large advantage over these engines. Essentially all of these applications are vehicular. The fuel cell can offer substantial advantages over the battery in weight, utility of use, and possibly even in capital costs in situations where the vehicle in question must be capable of performance of lengthy missions without battery pack charge or recharge.

\subsubsection{Specific Applications}

The principal conclusion concerning use of PAFC in remote applications is that economics will probably be attractive in Arctic applications before they compete in other environments. Outside the Arctic PAFC must compete with photovoltaic power as well as diesel generators. This competitor, which eliminates the need for costly remote-delivered fuel altogether, probably has an overwhelming 
long-term advantage in this market, particularly as its capital costs decline.

Concerning vehicular applications, fuel cells appear to be well suited for use in traction vehicles in which fuel cell weight can be tolerated. Examples of such traction vehicles which have

attractively high load factors and large numbers of annual operating hours include railroad locomotives and some underground mine locomotives (such as those used in tunnelling and some hardrock mines). Farm and construction traction vehicles are not good applications since they exhibit limited annual operating hours.

For use in vehicles which operate in environments where ventilation is limited, the fuel cell is likely to be in competition with lead acid batteries. Here, the fuel cell can enjoy substantial advantages in applications which daily consume energy equivalent to that required for full power operation for 8 to 12 hours. While most indoor industrial utility vehicles and underground mining vehicles receive far less use than this, some few high duty vehicles can be identified in which PAFC looks quite attractive. The best example is probably the underground mine locomotive and some forklift truck applications.

For the robotic submersible PAFC offers substantial opportunities for improving utilization. This may prove of great importance to the full development of the robotic submersible, which will swim untethered for many hours, performing simple tasks. For the foreseeable future, however, the phosphoric acid fuel cell must be considered to offer an opportunity to the submersible designer, rather than the submersible be considered an opportunity for PAFC. The size of the PAFC market which would be created by full development of the submersible is insignificant in terms of producing capital cost reduction via learning curve effects. 
A fuel cell is a device which reacts a fuel with an oxidant electrochemically, directly generating DC power. Several clasises of fuel cells are being developed for application using oxygen from the air as the oxidant and a hydrogen-rich gas as the fuel. Among these is the phosphoric acid fuel cell. It takes its name, as do most other fuel cell systems, from its electrolyte: phosphoric acid.

The phosphoric acid fuel cell has several advantages over most conventionally used fuel-based systems for generating electricity or shaft power. Perhaps most important, it offers high fuel efficiency. Even allowing for the inefficiency involved in processing a light hydrocarbon or alcohol fuel into a hydrogen-rich gas, it can offer efficiencies of power generation between 40 and $48 \%$.

The phosphoric acid fuel cell is a very clean power source. It can be operated with essentially negligible emissions of carbon monoxide, oxides of nitrogen, unburned hydrocarbons, and sulfur dioxide, with no discharge of polluted water. In addition to being much cleaner than any currently commercial internal combustion engine it is also much quieter. Furthermore, being based on a continuously conducted electrochemical process, with moving parts limited to a few pumps and valves, it might be expected that technologically mature fuel cell systems would display higher reliability than internal combustion engines with all their moving parts.

Given these attractions, it is not surprising that the phosphoric acid fuel cell is being actively evaluated for several classes of applications. Most notable are large, grid connected electric utility applications, residential/commercial total energy system applications, and small military power sources. The U. S. Department of Energy and the National Aeronautics and Space Administration concluded that it would be advantageous to commission a multi-disciplinary study to identify and begin evaluation of additional classes of applications, with the hope of finding highly promising but heretofore overlooked uses for the phosphoric acid fuel cell. The study was meant to consider:

- Major market segments. An example would be the railroad locomotive application evaluated here.

- Market entry application. Examples of these potentially high value applications would include the mine locomotive and Arctic village systems evaluated here.

- Specialty applications. An example of such an attractive but small market application would be the robotic submersible. 
- Export applications. It is expected that the railroad locomotive, mine locomotive, and Arctic village systems would all exhibit substantial export potential.

In the quest for such applications, consideration was given to any and all possibilities except for the three (utility, on-site, military) enumerated above and:

- Space applications

- Industrial cogeneration in the developed world;

- Opportunistic use of industrial waste hydrogen;

- Applications smaller than 10 kilowatts.

The study was conceived to proceed in four steps:

- Development of a Hardware Data Base describing competing power systems;

- Identification and classification of a large number of PAFC applications;

- Preliminary screening of the above-identified applications and technical evaluation of those selected;

- Further screening of applications and economic evaluation of those chosen.

The first two tasks were conducted in parallel. Task 3 began after the completion of tasks 1 and 2 , with task 4 following task 3 .

It was necessary to develop a Hardware Data Base in order to have a means of easily comparing candidate power systems for a large number of varied applications. The data base was developed so as to allow for estimation of system weight, volume, energy efficiency, and capital cost. Its development is described in Chapter 3; the Hardware Data Base itself is presented in Appendix A.

Contemporary with the development of the Hardware Data Base, a host of possible PAFC applications was identified. They were then classified so as to group together applications which have similar power system requirements. Application identification and classification are described in Chapter 4.

Applications so identified and classified were then screened for apparent suitability of PAFC use. A list of applications was chosen for further evaluation based on apparent PAFC suitability and on the 
desire to have a diverse list of applications for technical evaluation. The phosphoric acid fuel cell has been evaluated in competition with the conventionally used system in each of these applications. Factors considered included such technical criteria as weight, volume, and efficiency. This technical evaluation is described in Chapter 5.

Finally, the systems were further screened based on the results of technical evaluation and four selected for economic evaluation. This economic evaluation is described in Chapter 6. 


\subsection{COMPARATIVE POWER SYSTEM HARDWARE DATA BASE}

\subsection{INTRODUCTION}

In order to evaluate the possible merits of a phosphoric acid fuel cell (PAFC) system in a given application, it is necessary to develop information describing the PAFC power system and comparing it with the conventional power system used in that application. To facilitate such comparison in a wide variety of applications, a generalized data base has been developed to characterize PAFC power systems. This data base is structured to allow prediction of weight, volume, efficiency, and cost (design characteristics) of a wide variety of such fuel cell power systems designed to meet electrical or mechanical shaft power needs ranging from $10 \mathrm{~kW}$ to approximately $20 \mathrm{MW}$, the full capacity range of interest in this study.

In parallel, data has been developed on diesel engines (with and without generators), gasoline engines (without generators only), and industrial gas turbines (with and without generators), and lead acid batteries. Together with PAFC data this constitutes the hardware data base (HDB).

HDB development is described below, with sample data illustrated graphically. General guidelines for data base application and general conclusions to be drawn from the data base on phosphoric acid fuel cell applicability are also discussed. Complete tables of the data and instructions on its use in power system characterization are presented in Appendix A.

\subsection{PHOSPHORIC ACID FUEL CELL DATA}

\subsubsection{Organization}

A PAFC system may be analyzed as if constituted of a number of subsystems. Typically, the subsystems are identified as:

- Fuel storage

- Fuel processor

- Power section

- Power processor

- Power section cooling

- Heat rejection 
As needed, two more subsystems may be added:

- Oxidant storage

- Waste heat utilization

By properly defining the boundaries of these subsystems, including combining of certain subsystems, such as heat rejection with the fuel processor and power section cooling with the rest of the power section, it is possible to define a series of modules which collectively constitute a fuel cell power system. Proper module definition will allow substitution of, for example, one fuel processor module for another or one power processor module for another, all to be linked to the same power section module.

Design characteristics of each module are developed, based on the module's output. By characterizing each module as a function of its output, it is possible to develop estimates of total PAFC system design characteristics as a function of the magnitude and type of system output, type of fuel input, and a few choices related to system design (principally the choice of power section operating pressure and power density). This can be done for hundreds of possible phosphoric acid fuel cell power system configurations based on data developed on 29 modules.

The generic module types considered here are:

- Fue1 - one chosen for each system.

- Fuel storage - required for most fuels/applications.

- Oxidant storage - required in a few applications.

- Fuel processor - required for all systems using hydrocarbon or alcohol fuels, processing them into hydrogen-rich gases and managing and disposing of waste heat in such systems.

- Power section - for hydrocarbion or alcohol fueled systems, this module includes the fuel cells themselves, their immediate connected fuel, air, and coolant lines, the cell containment vessel, and the circulation system for the oxidizing air; for hydrogen-based systems, it also includes waste heat management and rejection (included in the power section as an accounting convenience since hydrogen-based fuel cell systems have no fuel processor).

- Power processor - transforms unregulated DC into required power form (i.e., regulated DC, three-phase AC, or shaft power).

- Heat utilization - required only in those applications which can use system waste heat; in most applications, a separate complete heat rejection system is also needed. 
Note that in addition to the hardware modules, it is convenient to consider the fuel itself as a module, since its choice determines fuel processor and storage options and since its inventory contributes significantly to fuel cell weight and volume. A module-by-module analysis is presented below.

This decoupled module approach is taken recognizing the fact that any actual PAFC system would be designed for close integration of the fuel processor/heat management system and the power section. For example, it is likely, as a result of this close coupling of system design, that the power section for a $20 \mathrm{~kW}$ power plant based on methanol will differ in very minor ways from the power section of a $20 \mathrm{~kW}$ fuel cell power system based on methane. Given the uncertainty of data available on this developmental technology, such minor details of design are not considered to introduce significant errors into the comparative analysis conducted here.

\subsubsection{Technical Premises}

The PAFC power system is a technology undergoing intense development. Work continues on improving the efficiency, and reducing the weight, volume, and cost of fuel processors, particularly for methanol and diesel fuel processing. More importantly, work continues on improving the performance and lowering the cost of the PAFC power section itself. Conduct of application analysis for this changing technology requires that some level of performance/technical development must be specified as the basis for the PAFC power system data. The basis chosen is the level of technology development reflected in the $40 \mathrm{~kW}$ natural gas-fueled fuel cell power plants now being deployed for on-site use and the 4.5 MW (AC) system now undergoing testing at Consolidated Edison (References A, B). It is these systems which serve as the model for estimating power section performance, volume, and weight. They also serve as the basis for evaluation of fuel processor volumes and weights for systems which would utilize conventional steam reforming (in this study, those which would utilize methane, ethanol, and LPG).

The level of technology development reflected in these systems is used as the basis for developing consistent estimates of design characteristics for power section modules fueled with essentially pure hydrogen and for power section modules operated at pressures up to $500 \mathrm{kPa}$ (Reference $\mathrm{C}$ ). In addition, an alternate high power density concept of stack design is characterized. It is based on operation of cell plates essentially identical to those found in the $40 \mathrm{~kW}$ on-site power system at much higher current densities than contemplated in that system, with lower attendant individual cell voltage and power section efficiency (Reference D).

Component costs are estimated based on prototype production of units for commercial rather than experimental/demonstration use (i.e., stripped down of extra instrumentation). This approach is taken in order to investigate whether any applications can be found which are economical at these prices and/or to determine what magnitude of cost 
reduction will be required to make the fuel cell competitive in each application. Opportunities for cost reduction via mass production will be considered in Task 4.

Finally, it should be noted that design characteristics of all systems considered here are projected for installed, stationary systems. of particular importance, weight and volume include steel chassis suitable for lifting the mounted components. Costs include labor, materials, and engineering for installation (only a few percent of prototype costs). Thus, these figures should not be applied out of context to vehicular applications. See Section 3.4.

\subsubsection{Results and Discussion}

\subsubsection{Fue1s}

Table 3.1 lists six potential PAFC fuels and their current and (if different) prospective future sources. These six fuels were selected for two reasons. First, all of the fuels are commercially available today and are expected to be available in the future, possibly produced from feedstocks other than petroleum. Second, they can either be used directly by fuel cell (pure hydrogen), or can be readily converted to hydrogen at a modest scale.

Table 3.2 lists the physical state in which the fuels are most likely to be encountered as a fuel. In addition, it lists many of the physical properties of these fuels. Vapor pressure vs. temperature data may be found in Table 3.3 .

Figure 3.1 displays current and recent past price trends for the fuels considered here. These prices are based on large-scale purchase as an industrial commodity. They are based on production from the current sources 1isted in Table 3.1 .

Future trends in prices of petroleum, coal, and natural gas can be expected to change the relative pricing relationships and may actually reorder the pricing hierarchy shown in Figure 3.1. This expectation is based on the following premises:

- The price of diesel fuel, representative here of prices of refined petroleum products, will experience some real price escalation during the next 35 years, the period of interest in this study.

- Prices of natural gas (methane) and LPG will rise to the level of refined petroleum products, but not exceed it due to opportunities to substitute oil for LPG or natural gas.

- Optimistically, it is assumed here that the price of methanol will decline to parity with that of refined petroleum products 


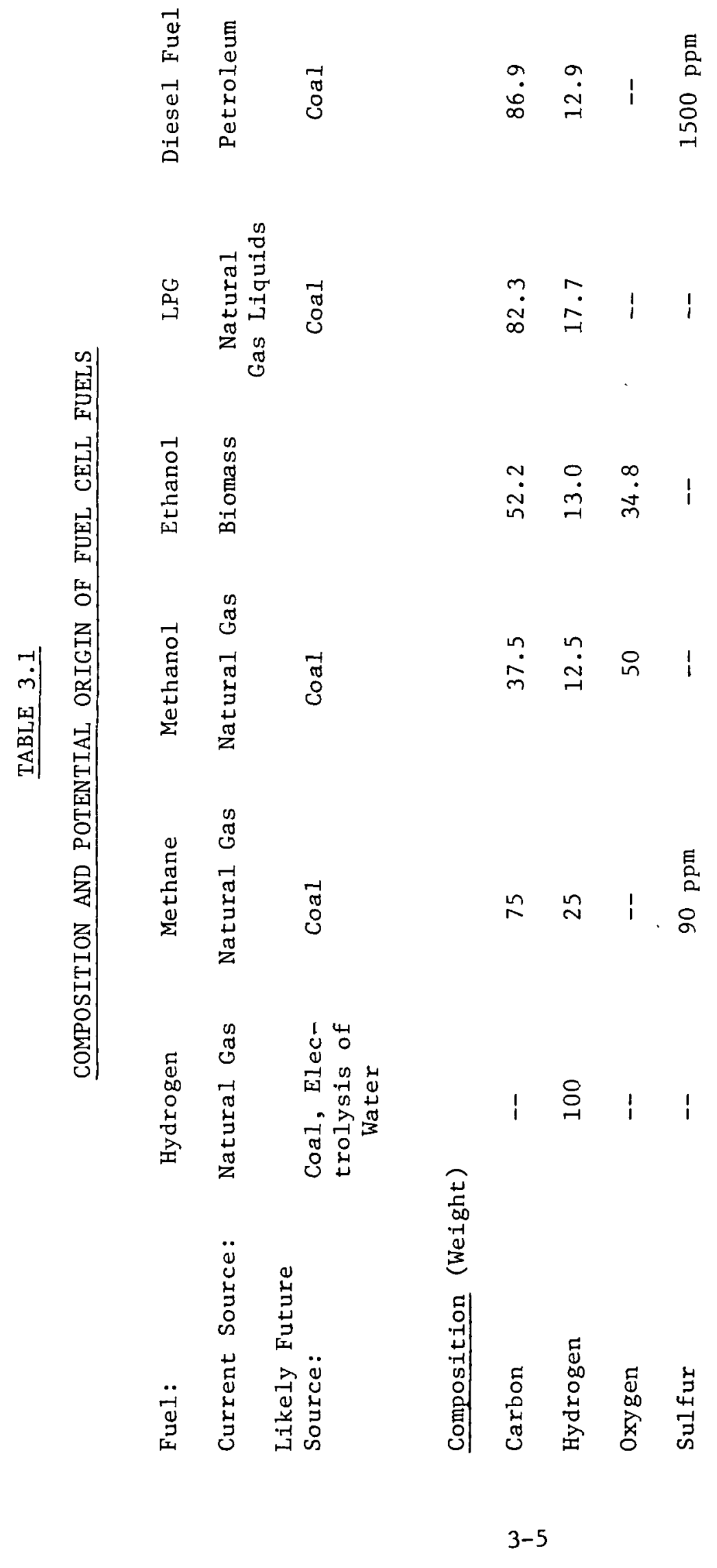




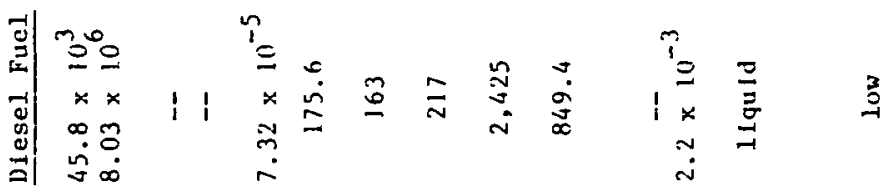

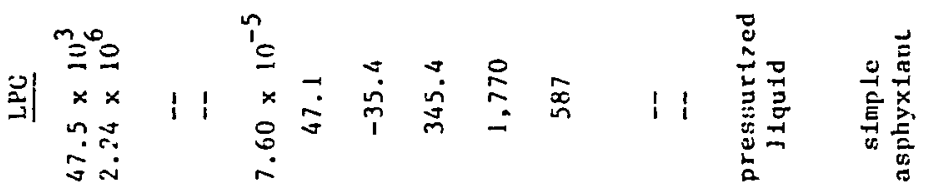

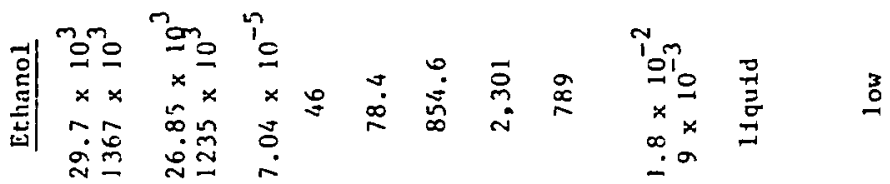

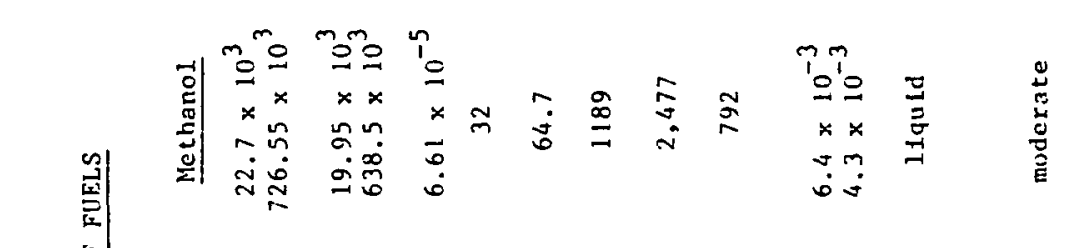

ty

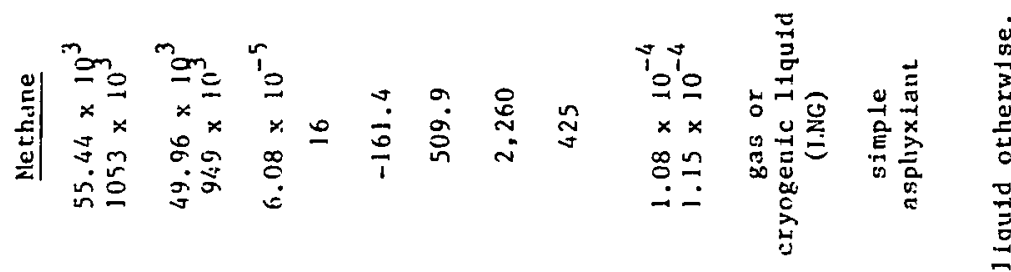

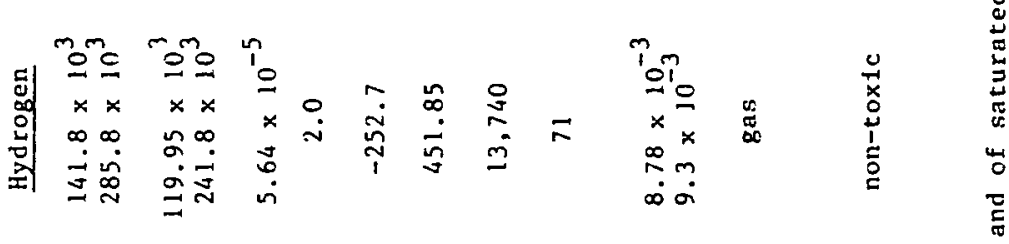

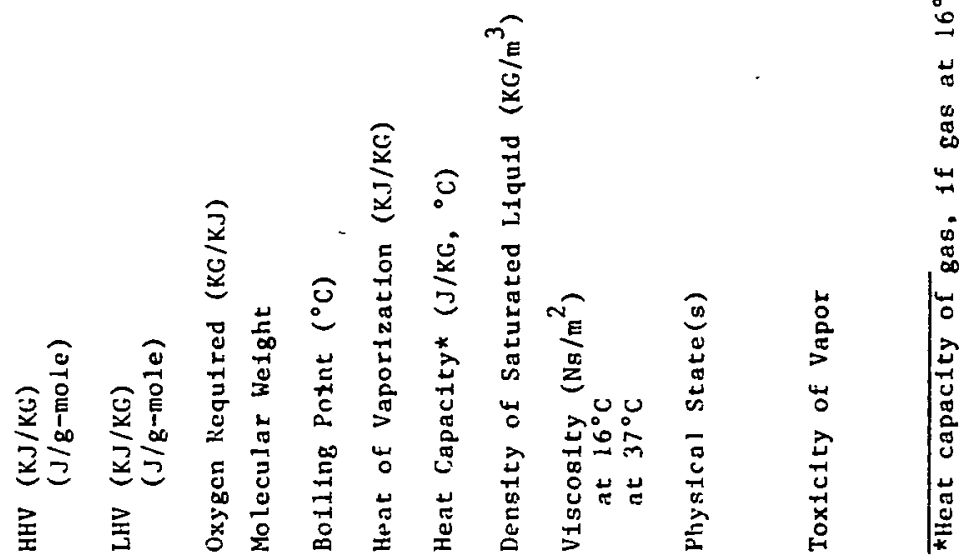


$\underline{\text { TABLE } 3.3}$

VAPOR PRESSURE VERSUS TEMPERATURE DATA

An equation which may be used to relate vapor pressure and temperature is:

$$
\log _{10} P=-\frac{0.05223 a}{T}+b
$$

where: $\quad P$ is in $\mathrm{MM} \mathrm{Hg}$

$\mathrm{T}$ is in ${ }^{\circ} \mathrm{K}$

The constants to be used in this relationship are:

\begin{tabular}{|c|c|c|c|}
\hline & $a$ & b & $\begin{array}{l}\text { Temperature } \\
\text { Range, }{ }^{\circ} \mathrm{C} \\
\end{array}$ \\
\hline Butane & 23,450 & 7.395 & -100 to +12 \\
\hline \multirow[t]{2}{*}{ Ethanol } & 45,240 & 9.705 & -12 to 115 \\
\hline & 35,640 & 8.406 & 115 to 230 \\
\hline Methane & $8,516.9$ & 6.8626 & -174 to -163 \\
\hline Methanol & 38,324 & 8.8017 & -10 to +80 \\
\hline Propane & 19,037 & 7.217 & -136 to -40 \\
\hline
\end{tabular}




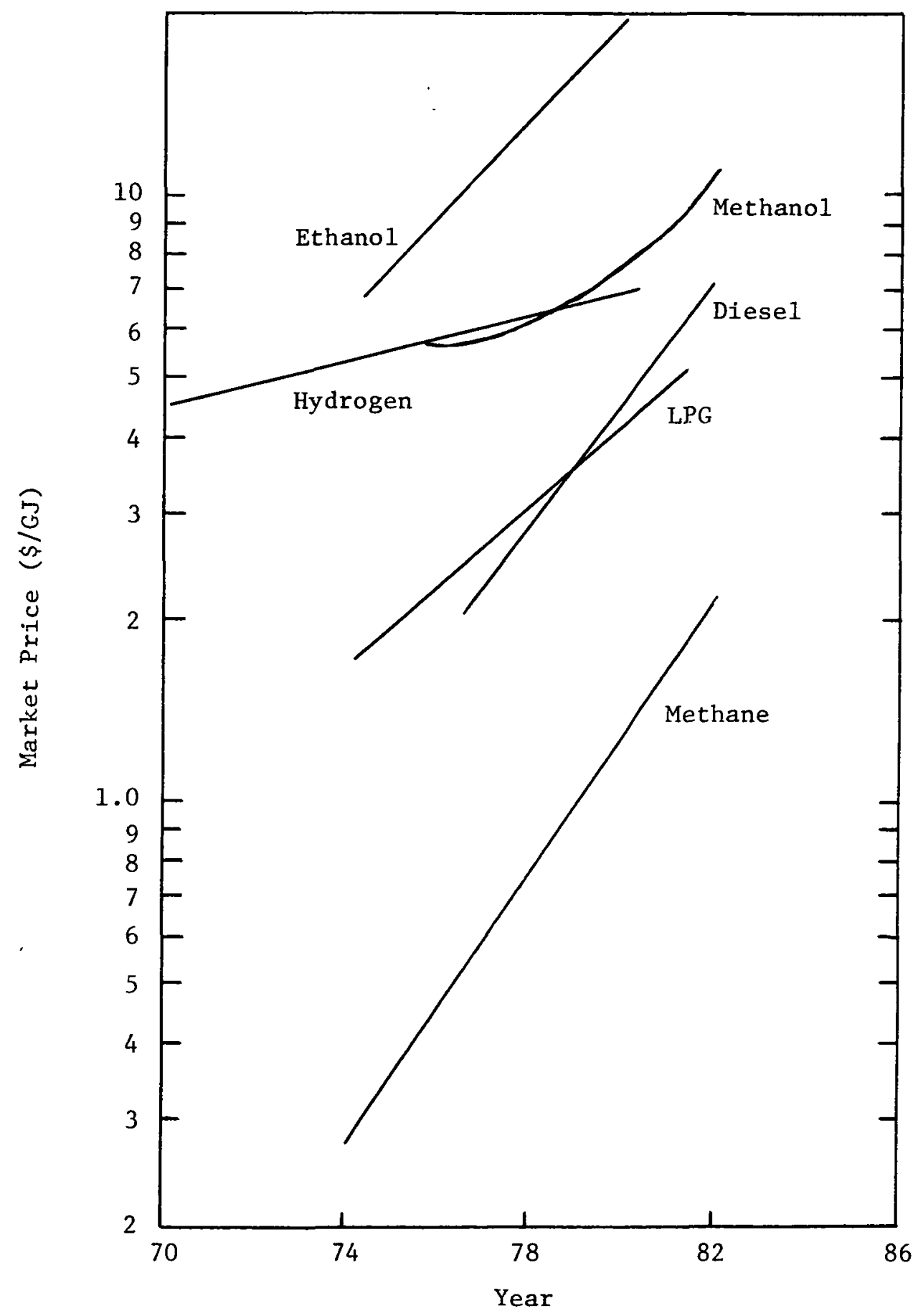

FIGURE 3.1 - FUEL PRICES 
but not fall below it, due to the very large motor fuel demand to be served at that price.

- The price of ethanol will remain high, due to the high cost of producing it from grain.

- The price of hydrogen, produced in relatively small quantities to recharge systems such as those considered here, is based on production from methanol in equipment similar to the methanol fuel processor described below.

The relative decline in methanol prices is expected to occur in the near term on the basis of production from foreign natural gas and to be sustained in the long term based on production from coal. In the near term, substantial increases in methanol production are projected worldwide. This increased production will be based primarily on low production cost natural gas deposits, many of which are geographically isolated from large energy demand centers where the gas might be used as fuel. This gas may be expected to be available to a methanol producer at prices substantially below that of petroleum. With substantial production expected from such sources, methanol prices are projected to increase more slowly in the near term than the prices of any other fuel considered here.

Concerning the long-term outlook, most analysts foresee petroleum prices rising at a rate faster than that of general inflation over the next 35 years, although there may be periods of temporary declines. Such price rises would be driven by depletion of this resource. Coal, by contrast, can be expected to rise in price at a rate comparable to that of general inflation, with no significant depletion effects. It may be expected that there will come a time when coal-based production of methanol will yield a liquid fuel at a cost per million Btu lower than the petroleum-based cost of any portable liquid fuel considered here. Farther in the future, coal- and/or oil shale-based production of diesel fuel, LPG and possibly coal-based production of methane may directly displace petroleum and natural gas-based production of these commodities, but at higher costs per giga joule than for coal-based production of methanol.

Rather than projecting future petroleum-based fuel prices year by year, a single price will be used to reflect future real price escalation discounted to the present, as it might be viewed by a potential fuel cell user. These single lifetime levelized constant dollar prices (LLP) are calculated as follows:

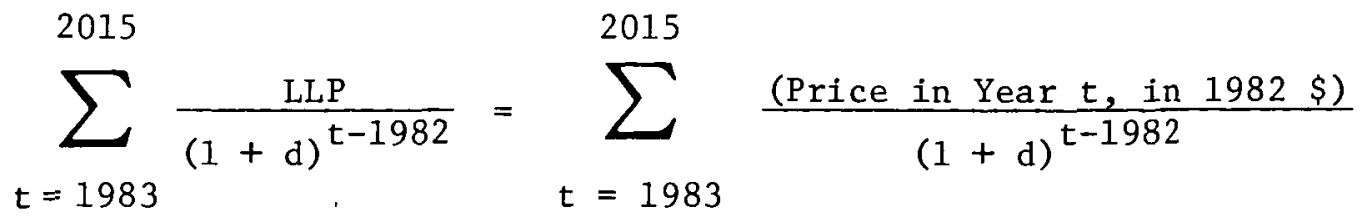


Where $\mathrm{d}$ is the discount rate. Solving for LLP yields:

$$
L L P=\frac{\sum_{t=1983}^{2015} \frac{(\text { Price in Year } t \text {, in 1982 \$) }}{(1+d)^{t-1982}}}{\sum_{t=1983}^{2015} \frac{1}{(1+d)^{t-1982}}}
$$

This device for representing fuel prices has the following advantages:

- It allows a single annual operating cost calculation to represent operating costs which might be experienced throughout system life.

- It eliminates details of future fuel price escalation patterns from consideration in evaluation of individual applications. Exact details of future year-by-year price escalation are purely speculative, and should not play a direct role in this analysis.

- It allows consideration of all fuel pricing uncertainties in one parameter, which can be subjected easily to sensitivity analysis.

An average annual real price escalation rate of $0.94 \%$ is used together with a real discount rate of $3.5 \%$ and a 1982 petroleum products (diesel fuel) price of $\$ 7 / G j$ to project a LLP for diesel fuel of $\$ 8 / G j$, again in 1982 dollars. This and other fuel price projections are shown in Table 3.4 .

\subsubsection{Fue1 Storage}

The five most likely modes of fuel storage and the fuels for which each mode is most appropriate are listed in Table 3.5. Storage vesse1 cost, volume, and weight data were developed as functions of energy content (higher heating value) of fuel stored, the functional form applicable in the data base. Complete data is supplied in Appendix A. Sample weight, volume, and cost data are presented in Figures 3.2, 3.3, and 3.4. Note that cost does not include the contribution of stored fuel itself, but weight does.

\subsubsection{Oxidant Storage}

Fuel cells for unusual applications might obtain oxygen from liquid storage. Table 3.6 lists the physical properties of liquid oxygen, along with data on liquid oxygen storage system weight, volume, and cost developed on the basis of weight of oxygen stored. This is used 
TABLE 3.4

LIFETIME LEVELIZED FUEL PRICES USED IN THIS STUDY

(Constant 1982 Dollars)

Fuel:

Hydrogen

Methane

LPG

Methanol

Ethano1

Diesel

Fue1

Delivered Cost,

$\$ / G j$

19.00

8.00

8.00

8.00

19.00

8.00 
TABLE 3.5

FUEL STORAGE MODES

Storage Mode

Conventional Liquid

Compressed Gas

Cryogenic Liquid

Hydride

Pressurized Liquid
Fuels

Methanol

Ethano1

Diese1 Fuel

Hydrogen

Methane

LNG

Hydrogen

LPG 


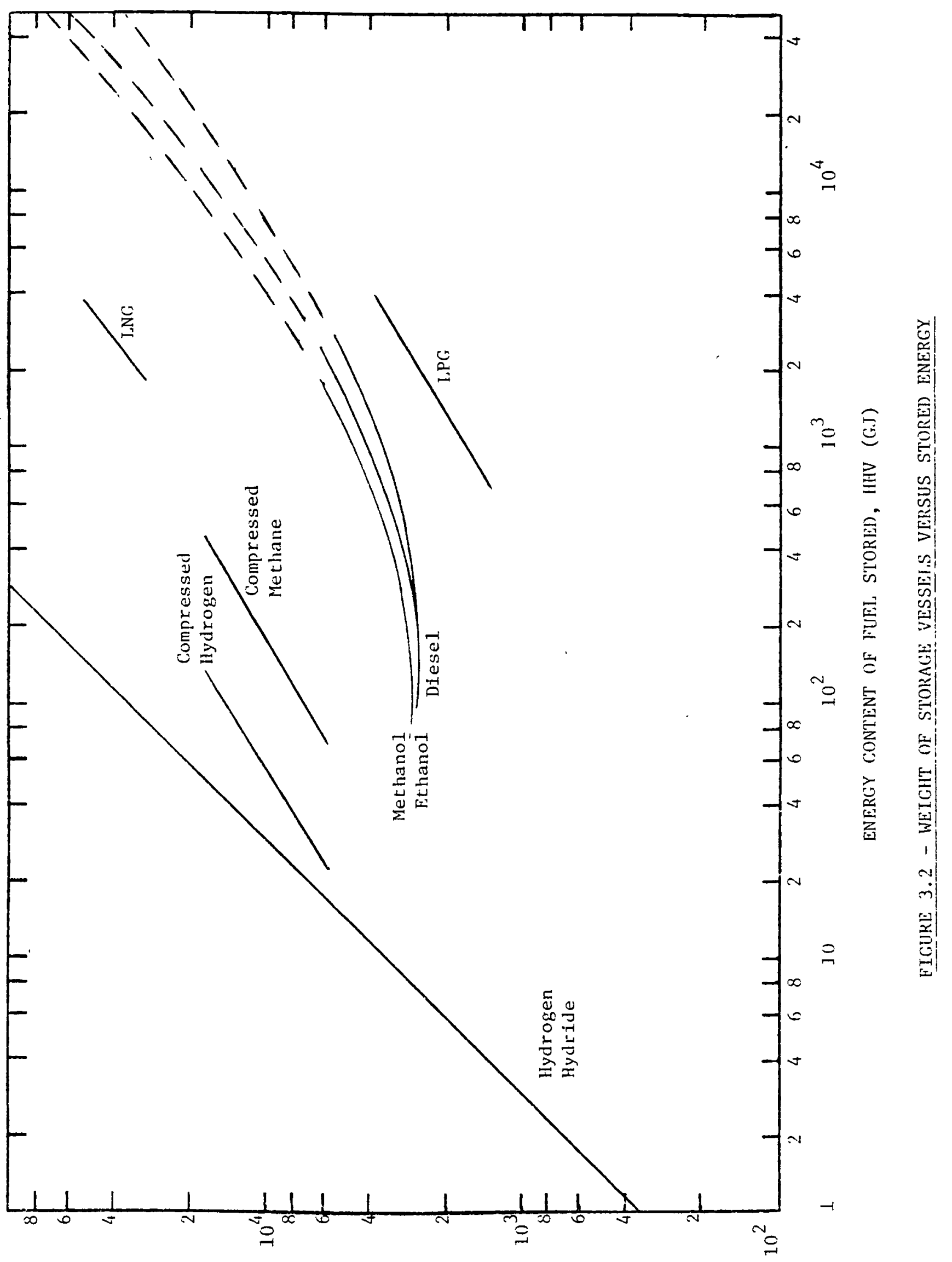

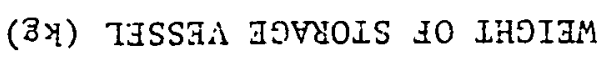




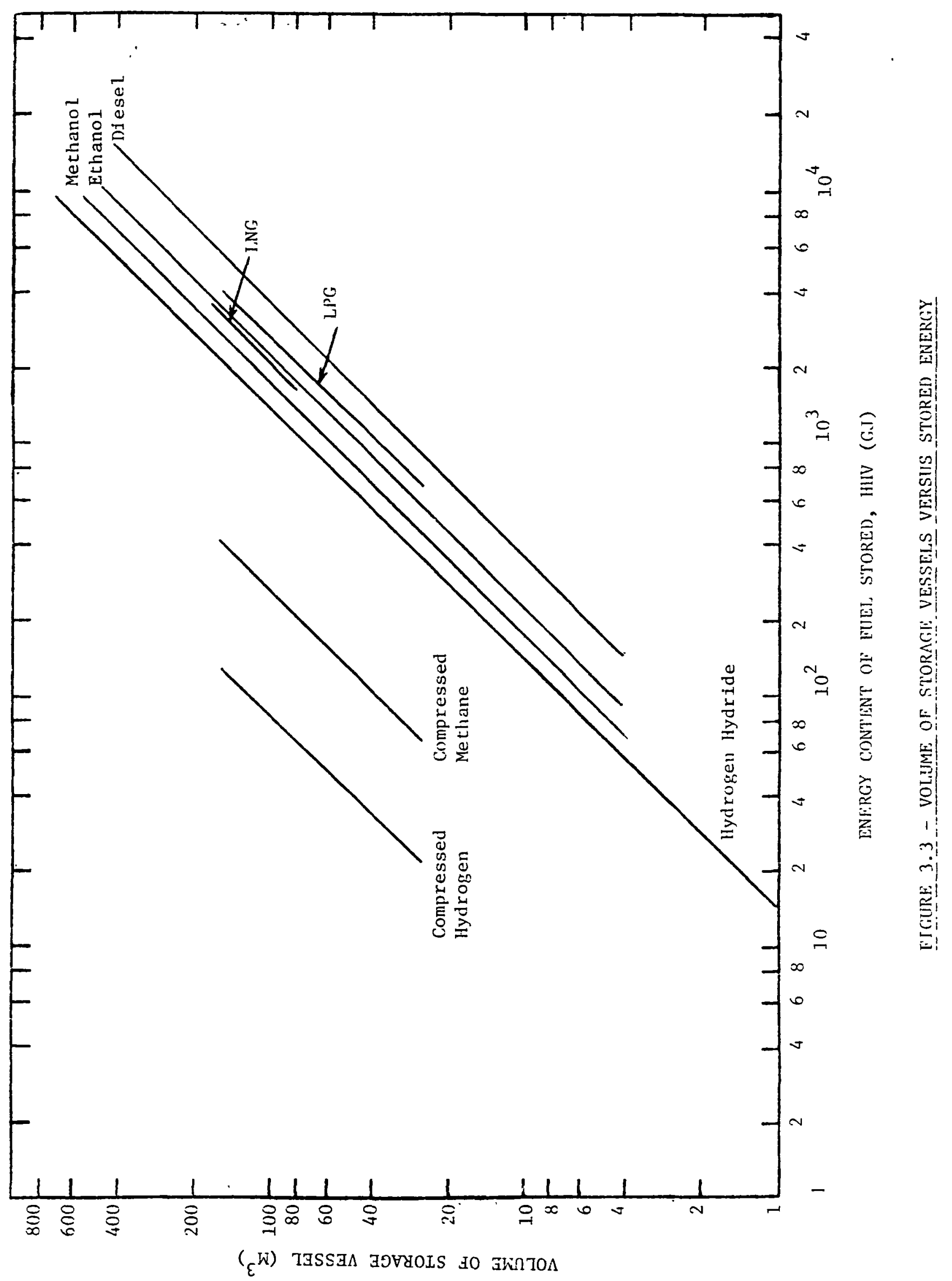




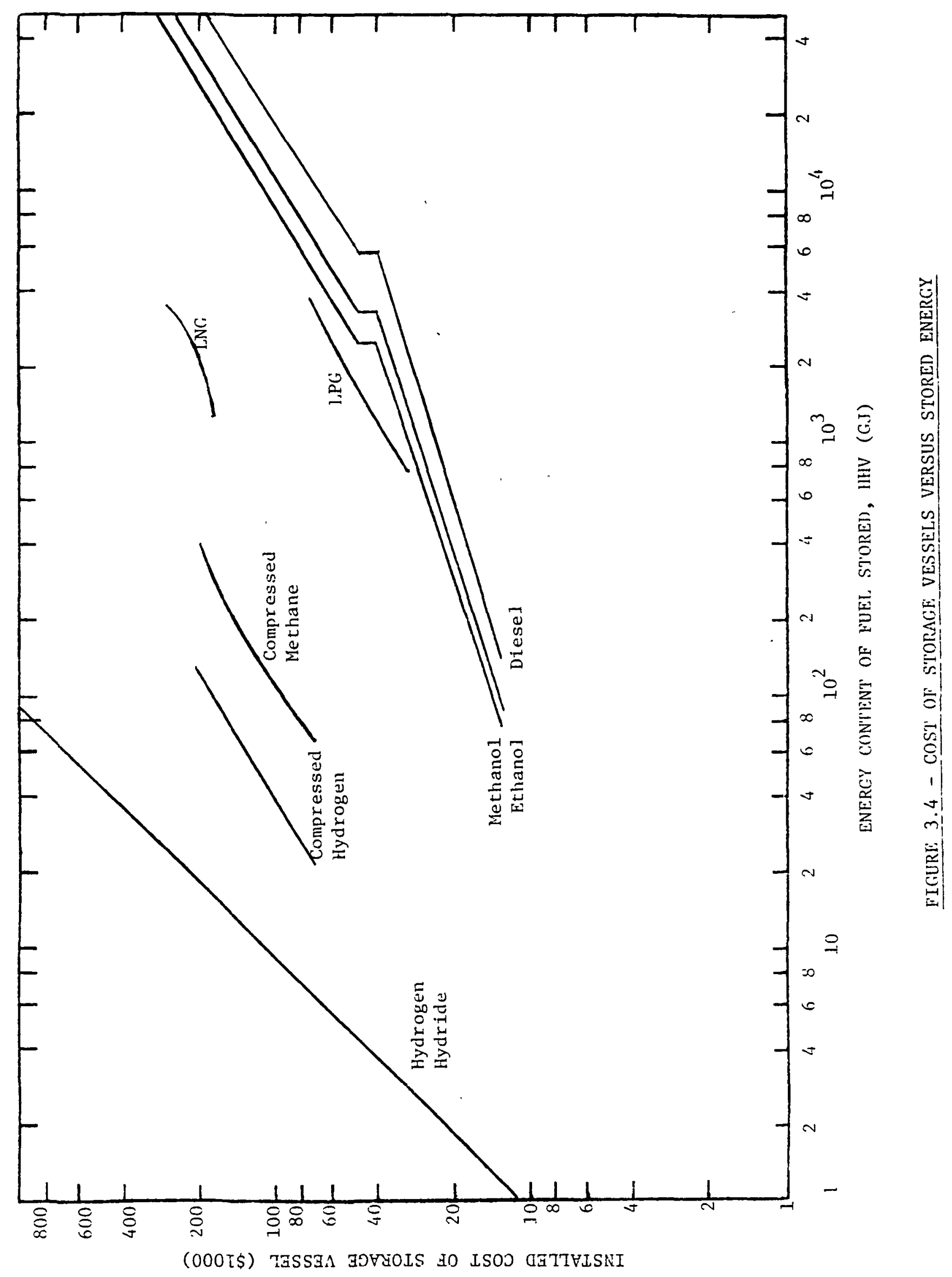


TABLE 3.6

\section{PROPERTIES OF LIQUID OXYGEN}

Molecular Weight

Boiling Point $\left({ }^{\circ} \mathrm{C}\right)$

Heat of Vaporization (KJ/KG)

Heat Capacity of Gas $\left(\mathrm{J} / \mathrm{KG} \cdot{ }^{\circ} \mathrm{C}\right.$ )

Density of Saturated Liquid $\left(\mathrm{KG} / \mathrm{M}^{3}\right)$

Weight of X KG Liquid $\mathrm{O}_{2}$ Storage, KG

Volume of $X$ KG Liquid $\mathrm{O}_{2}$ Storage, $\mathrm{M}^{3}$

Cost of X KG Liquid $\mathrm{O}_{2}$ Storage, $\$ 1000^{\prime} \mathrm{s}$

\section{3}

1665

1150

$2.2(\mathrm{x})^{0.83}+\mathrm{x}$

$0.0012(x)^{0.98}$

$0.27(x)^{0.57}$ 
on a case-by-case basis to describe oxygen storage needed in certain specialized applications.

\subsubsection{Fue1 Processors}

Module Scope. The fuel processor portion of the fuel cell power system takes a hydrocarbon or alcohol fuel such as natural gas and processes it into a hydrogen-rich gas which can be utilized by the fuel cell power section. In order to maximize overall power system thermal efficiency, the fuel processor typically includes extensive thermal management equipment to make the greatest possible use of waste heat and to condense water from the cathode exhaust. Since fuel processing and thermal management are so intimately linked, the two are considered together in this analysis, within the fuel processor systems. Reasons for combining these functions within one module include:

- As noted, thermal management is a part of fuel processing; any division between the two operations is somewhat artificial.

- Al1 components of this subsystem may be considered to fall within conventional engineering practice; thus, their performance may be characterized with relatively high and uniform levels of accuracy. Such an accounting divides the active fuel cell power system components so as to separate the relatively conventional fuel processor/ thermal management functions from the more developmental fuel cell power section.

- Limiting power section scope principally to the cell stack itself simplifies accounting of replacement cell costs.

This method of accounting fuel processing/thermal management functions was judged to offer the most utility for the analysis to be conducted here. However, like any other simplification of reality, it introduces accounting difficulties and error. Principal difficulties are listed below, together with remedies taken and/or estimates of errors:

- Heat rejection. Only one fuel processor design concept is characterized for each fuel. No distinction is drawn between a fuel processor coupled to a power section which is operated at ambient pressure or to a power section operated at $500 \mathrm{kPa}$; neither is one made between low and high power density operation. Such treatment accurately portrays fuel processing itself, since fuel processing always occurs at pressures greater than any power section pressure contemplated here (all fuels are introduced as liquids except methane, which is allowed to be delivered at high pressure); no compression is required to deliver processed fuel to the power section. However, it overlooks the fact that the ambient pressure 
power section will generate more waste heat per unit fuel consumed than will its $500 \mathrm{kPa}$ counterpart. For a given pressure, a high power density power section will produce more waste heat than a low power density system. Thus, a heat rejection system designed for use with an ambient pressure high power density power section will be significantly larger than required for use with a low power density pressurized power section. To minimize resultant errors, fuel processor/thermal management modules are characterized based on the requirements of ambient pressure, low power density operation at $40 \mathrm{~kW}$ of generating capacity and based on the requirements of pressurized low power density operation of 4.5 MW of generating capacity. Since no pressurized systems are expected to be used in sizes smaller than $100 \mathrm{~kW}$ (exception: see below) this should provide appropriate ambient condition-based estimates for low power density systems in the small size range. Similarly, all megawatt sized systems are expected to be pressurized and will be accurately modeled by this method. Maximum errors will occur in estimating weights, volumes, and costs of systems sized for approximately $100 \mathrm{~kW}$ of electricity generation based on pressurized power section. Here, the single-pressure fuel

processor model will overestimate fuel processor weight by $1.5 \%$, volume by $5 \%$, and cost by less than $0.5 \%$. Since all of these errors are much smaller than the $+30 \%$ error which must be ascribed to all fuel processor analyses, they are neglected.

- Heat rejection requirements of low power density systems are used in fuel processor design as noted above since this is the base case power section concept. Again, errors introduced by this simplification are much smaller than the $\pm 30 \%$ which must be ascribed to all fuel processor anâlyses.

- Hydrogen fueled system heat rejection. A system based on pure hydrogen $\left(99.9+\% \mathrm{H}_{2}\right)$ requires no fuel processor, but it does require waste heat management. A very small amount of stack waste heat will be used for regenerating hydride-stored hydrogen, but most must be rejected to the environment. This is the fuel processor function which is most intimately coupled to the power section. As will be noted below, a separate analysis must be conducted of hydrogen-based power sections to account for the higher cell voltages achieved and the lower parasitic power consumption associated with hydrogen use. Since such a separate analysis must be conducted anyway, weight, volume, and cost of heat rejection are accounted in the power sections of hydrogen based systems. No separate fuel processor is considered. 
- Exceptional cases. This simplified approach provides substantial utility in analyzing most applications. It does not lend itself to modular description of applications such as submersibles, which use pure oxygen as a reactant and accomplish heat rejection via once-through cooling. Such a system is analyzed as a special case.

Processing 0ptions. The heart of any fuel processor is the reformer. PAFCs can only use hydrogen as a fuel, and the overall function of the fuel processor is to convert more readily available fuels into hydrogen. The reformer performs the key function in this process: reacting a gas phase hydrocarbon or alcohol with steam to form a mix of hydrogen, steam, carbon monoxide, and carbon dioxide.

The choice of reformer technology is dictated by the nature of the fuel or fuels to be utilized. Methanol is by far the most easily reformed of the fuels considered here. It is reformed with steam in the presence of a copper-based catalyst at temperatures as low as $250^{\circ} \mathrm{C}$.

Reforming methane, ethanol, or LPG is more difficult. Much higher reformer temperatures are required, typically $900^{\circ} \mathrm{C}$, using a nickel-based catalyst.

Diesel fuel is the most difficult to reform of the primary fuels considered here. If a steam reforming reaction analogous to that conducted with methane is attempted at high temperatures with a sufficiently long residence time to provide for high rates of conversion of diesel fuel, some coking will occur within the reformer, reducing catalyst activity and interfering with heat transfer. In order to avoid this problem, diesel fuel is reformed in two steps. First, it is subjected to temperatures of approximately $950^{\circ} \mathrm{C}$ over calcium aluminate catalyst in the presence of steam to yield a partially reformed gas containing a high percentage of methane. Next, this gas is mixed with air and partially oxidized, raising its temperature to about $1000^{\circ} \mathrm{C}$. The hot gases are passed over a sulfur tolerant nickel catalyst changing their composition to yield additional hydrogen from the methane.

All newly reformed gases must be subjected to shift conversion, producing carbon dioxide and additional hydrogen from carbon monoxide and water vapor. Depending on the fuel feed and reformer type, desulfurization (before or after reforming) and preoxidation (before reforming) may also be required.

Table 3.7 lists characteristics of four classes of fuel processors analyzed. As can be seen, systems for processing methanol are by far the simplest, smallest, most efficient, and least expensive of the fuel processors. The low temperature reformer acts as a shift converter as well. No sulfur control is required on this inherently low sulfur fuel. Fuel preoxidation is not required. However, this fuel processor is designed around a single fuel and cannot operate on any others. Two variations 
TABLE 3.7

SALIENT FEATURES OF FUEL PROCESSORS

Fuel(s)

Reformer

Shift Conversion

Required

Fuel Desulfurization

Requirement

Configuration

Preoxidizer Required

Cathode Exhaust Water Recovery

System to Support 1000

KWAC Generation

$$
\begin{aligned}
& \text { Weight, Kg } \\
& \text { Volume, } \mathrm{M}^{3} \\
& \text { Cost, } \$ 1000^{\prime} \mathrm{s}
\end{aligned}
$$

System Therma1

Efficiency
Methanol

Low

Temperature

Steam

Reformer

In LTSR

None

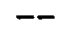

No

Yes

11,000

48

394

$93.9 \%$
No

No

Methanol/

Water Mix

Low
Temperature
Steam
Reformer

In LTSR

None

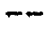

10,000

37

376

$93.9 \%$
Ethanol, Methane

$$
\text { LPG }
$$

\section{Conventional High Tempera- Steam \\ Reformer ture Steam/ Autotherma 1 Reformer}

Separate

Separate

$$
\begin{aligned}
& \text { Minor } \\
& \text { Before } \\
& \text { Reformer }
\end{aligned}
$$

\section{Significant}

Between Reformer and Shift Converter

No

Yes

Yes

33,000

123

123

908

908

$89.3 \%$

$87 \%$ 
are considered: a system utilizing internally recovered water for reforming and a system using a methanol/water mix as fuel, eliminating water recovery and thereby minimizing system weight and volume (important in some vehicular applications) (References $D$ and E).

Information was developed describing one fuel processor based on a conventional steam reformer (CSR) capable of producing hydrogen from methane, ethanol, or LPG (References A, B, and F). As much as possible, this module was characterized using information available on the $40 \mathrm{~kW}$ on-site units and Consolidated Edison's $4.5 \mathrm{MW}$ unit. While it is recognized that subtle differences will exist among processors designed for these fuels (notably, the ability to use stack waste heat to evaporate liquid fuels), these differences will have little effect on system weight, volume, cost, or efficiency and will be much smaller than the error margins associated with this data; therefore, no such distinctions are made.

Two fuel processor concepts were originally considered for processing diesel fuel (Reference $G$ ). The first, based on a simple autothermal reformer (ATR), was rejected because its efficiency was too low. When combined with appropriate power section and power processor modules, simple ATR produced fuel cell power systems which were less efficient than diesel generators. Since it resulted in power systems which lacked the fuel cell's vital advantage of efficiency, it was not expected to play a useful role in the analysis conducted here.

The concept chosen is based on a two-stage reformer (TSR), similar to that being developed by Toyo Engineering Corporation. This choice was made because of the high thermal efficiency achievable with this system, in spite of the relatively primitive state of development of the TSR. Use of such a reformer was judged to be desirable if diesel fueled fuel cell systems are to be of commercial interest.

Due to its primitive state of development, it was necessary to project system weight, volume, and cost by analogy with those developed for the CSR-based system considered above. Comparison of system schematic flow diagrams (References $F$ and $G$ ) indicated that weight, volume, and cost of the TSR module would all be very similar to the CSR-based module. Given the developmental nature of this process and the associated process and hardware uncertainties, the two modules are assumed to be of equal weight, volume, and cost for a given rate of usable hydrogen output.

Thermal Efficiency. Fuel processor efficiencies are calculated according to the formula:

Higher Heating Value of Hydrogen Consumed in the Power Section Higher Heating Value of Fuel Fed to the Fuel Processor 
Use of this simple formula together with the formulations adopted for the power section of the power processor allow calculation of overall system thermal efficiency simply by multiplication of subsystem thermal efficiencies. Thus, the methanol fuel processors are expected to achieve thermal efficiencies of approximately $94 \%$. All fuel processors based on conventional steam reforming are expected to achieve thermal efficiencies of approximately $89 \%$, for any of the three fuels considered. Diese1 fue1 processor thermal efficiency should be limited to $87 \%$.

Note that this formulation takes no account of availability of waste heat. Such an account will be made on an as-needed basis for evaluation of fuel cell systems and specific applications.

\subsubsection{Power Section}

An array of possible power section modules was considered. They are summarized as follows:

- Power sections with three operating pressures were analyzed. These were ambient pressure, $300 \mathrm{kPa}$ and $500 \mathrm{kPa}$. These pressures were chosen because they span the range of pressures considered for phosphoric acid fuel cells based on current technology.

- Cell stacks based on two types of fuel feed were evaluated-hydrogen-rich gas based on steam reforming and shift conversion of a hydrocarbon or alcohol fuel, and $99.9+\%$ pure hydrogen. It was necessary to draw this distinction in considering possible stack designs, performance, and cost because an individual cell operated on high purity hydrogen will operate more efficiently (i.e., at higher cell voltage) at any given current density than its hydrocarbon or alcohol counterpart, while utilizing $99+\%$ of the hydrogen fed to it (Reference C). In addition, a hydrogen-based system will have significantly lower parasitic power requirements. Although these savings would actually be realized elsewhere in the system, they must be accounted in the stacks since this is where all parasitic power consumption is reported. Also, as noted above, these power section modules must include accounting of waste heat rejection, included in fuel processors of hydrocarbon or alcohol fueled systems.

- Consistent with system design principles incorporated in the 40 kilowatt on-site fuel cell power systems being deployed today and the 4.5 megawatt systems being tested in New York City, primary design and performance-data were developed based on relatively high efficiency/low current density operation. Corresponding power density in the ambient pressure system is approximately $120 \mathrm{milliwatts} / \mathrm{sq}$ centimeter. As an alternative, a more compact, lower weight concept was 
also analyzed. For this alternate case, power section design/performance parameters were developed based on moderately lower efficiency/much higher current density operation corresponding to $200 \mathrm{milliwatts} / \mathrm{sq}$ centimeter of cell in the ambient pressure system.

All power section concepts considered here are liquid cooled. It is recognized that air-cooled power sections are under development; however, available data was inadequate to draw meaningful distinctions between the two classes of power sections. Accordingly, no comparative data is presented. All subsequent analysis will be based on these liquid-cooled concepts.

Power section efficiency is defined as:

(Gross Power Generated, $\mathrm{kW}$ ) - (Approximate Parasitic Power Consumption of Entire PAFC Power Plant, $\mathrm{kW}$ )

Higher Heating Value of Hydrogen Consumed, $\mathrm{Kj} / \mathrm{Sec}$.

Estimates of parasitic power consumption are based on methane fueled systems. They are approximately correct for LPG, ethanol, and diese1 fueled systems. They overstate parasitic power requirements in methanol fueled systems; hence, they slightly underestimate the overall efficiency of these power plants (error less than $0.5 \%$ ). Variations in pressurized fuel cell efficiency with system capacity result from variations in parasitic power requirements.

Table 3.8 lists all fuel cell stack concepts incorporated into the data base, and thermal efficiencies and capital costs for power section modules sized for a $1000 \mathrm{~kW} \mathrm{AC} \mathrm{plant.} \mathrm{Complete} \mathrm{data} \mathrm{describing} \mathrm{these}$ systems is provided in Appendix A. Limited analysis of additional systems not listed in Table 3.8 or Appendir A was conducted as needed for evaluation of certain specialized applications.

\subsubsection{Power Processor/Motor}

The fuel cell stack generates unregulated direct current output. In some applications this may offer an acceptable substitute for the conventional system as is. In most electrical power type applications, however, three-phase alternating current is required. In applications in which the conventional system produced shaft power, the electricity used to run a motor must be conditioned prior to feed to that motor. Thus, in general, the DC output of the fuel cell must be processed further before use.

Power processor efficiencies are defined as:

Regulated/Inverted Power Out, kW Unregulated DC Power In, kW

Motor efficiency is defined as:

Shaft Power Out, kW

Regulated DC Power In, $\mathrm{kW}$ 

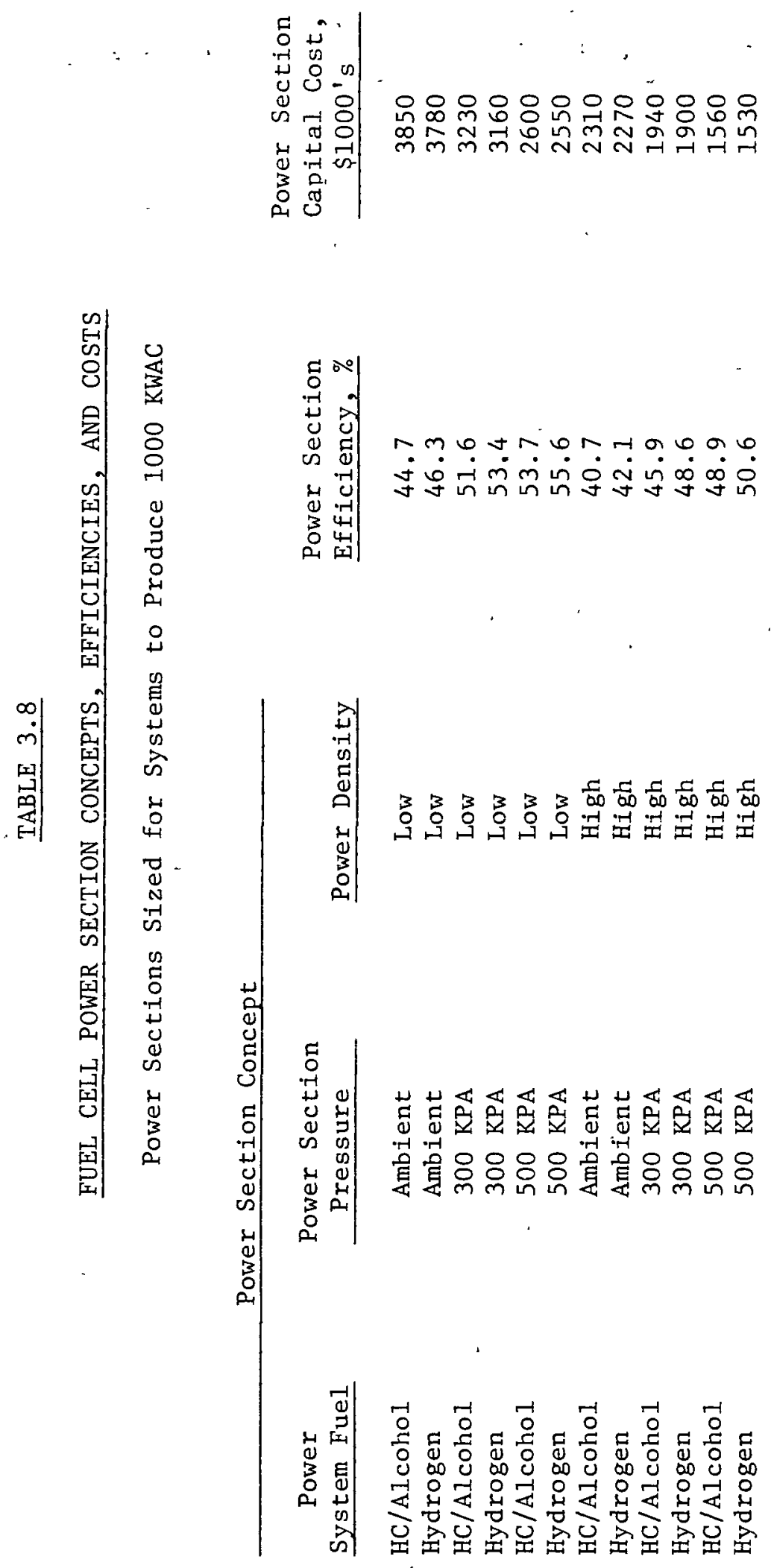
The efficiencies of these components are expected to be approximately (References $\mathrm{H}, \mathrm{I}$, and $\mathrm{J}$ ):

- $\mathrm{DC} / \mathrm{AC}$ inverter, $96 \%$.

- DC/DC converter, $93 \%$.

- DC motor, $92 \%$.

Figures 3.5 through 3.7 display the weight, volume, and cost of $\mathrm{DC} / \mathrm{AC}$ inversion and DC/DC conversion systems. Complete tabular weight, volume, and cost data for power conversion, including DC motors, is presented in Appendix A.1.

\subsubsection{Heat Recovery}

Some applications present opportunities to make economical use of waste heat generated by the fuel cell. In these applications, this heat must be recovered from the fuel cell cooling system and possibly from the cathode exhaust. When this heat is recovered, the heat rejection systems, which are part of the fuel processor in the hydrocarbon/alcohol fueled systems or of the power section in the hydrogen fueled systems, will not be used. In general, however, it would not be prudent to delete these heat rejection systems, since there will almost certainly be times when the fuel cell's power will be required but not its heat and heat will have to be rejected in order to sustain operation. Thus, only some applications will require a heat recovery module, but all will require heat rejection, as previously accounted in fuel processor and power section modules. Exceptions to this rule are analyzed as special cases.

When choosing a heat exchanger, the design parameters which must be considered are volume, weight, and cost. These three parameters are directly related to heat exchange area through the basic heat transfer equation:

$$
\mathrm{Q}=\mathrm{UA} \Delta \mathrm{T}
$$

where: $Q=$ heat duty

$$
\begin{aligned}
U= & \text { heat transfer coefficient } \\
\mathrm{A}= & \text { heat exchange area } \\
\Delta \mathrm{T}= & \text { temperature difference between process and } \\
& \text { utility fluids }
\end{aligned}
$$

Rearranging this equation yields:

$$
\mathrm{A}=\frac{\mathrm{Q}}{\mathrm{U} \Delta \mathrm{T}}
$$

Over essentially all of the size range considered here, the weight, volume, and cost of the heat exchange can be expected to be a function of area. 


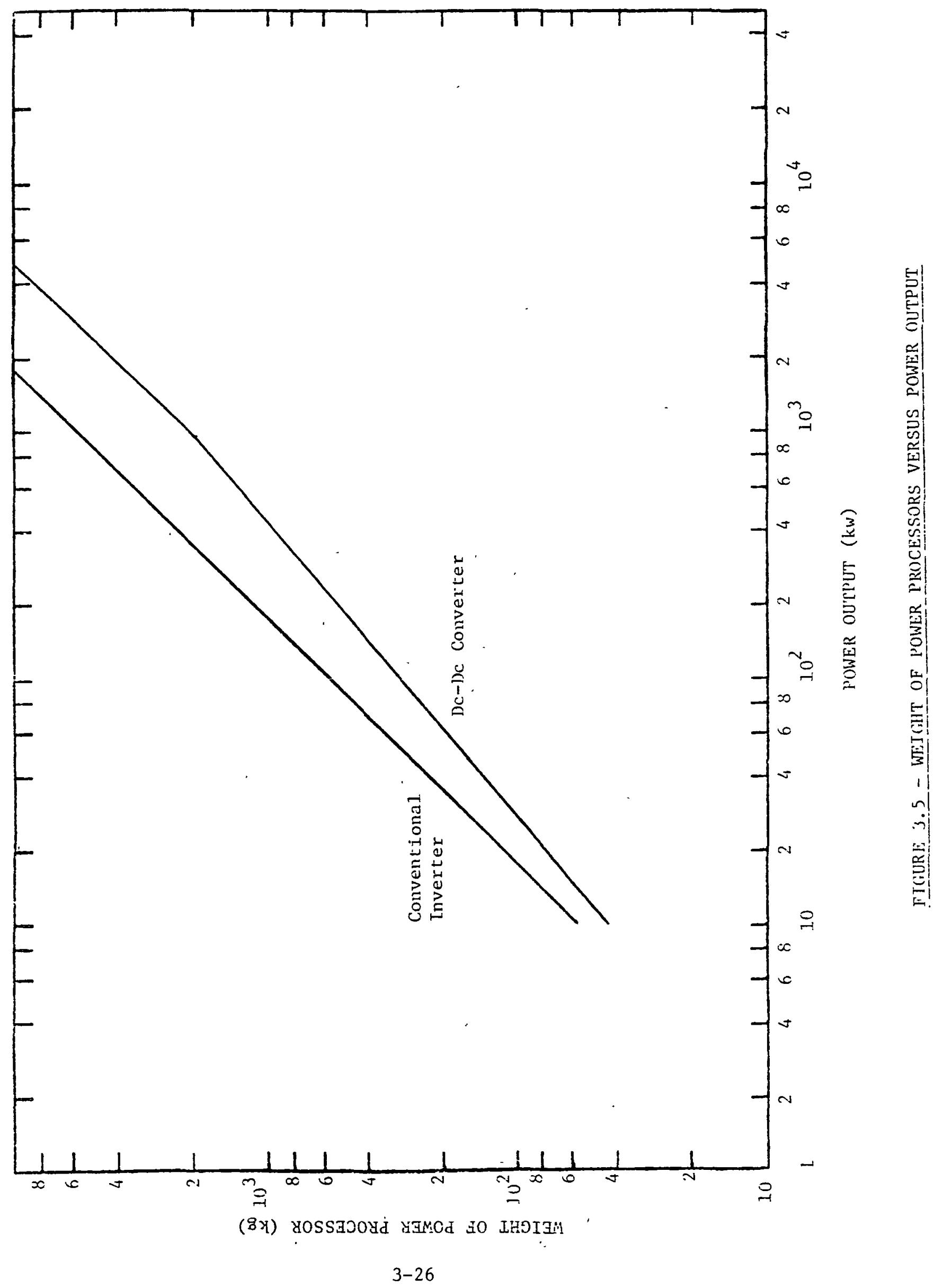




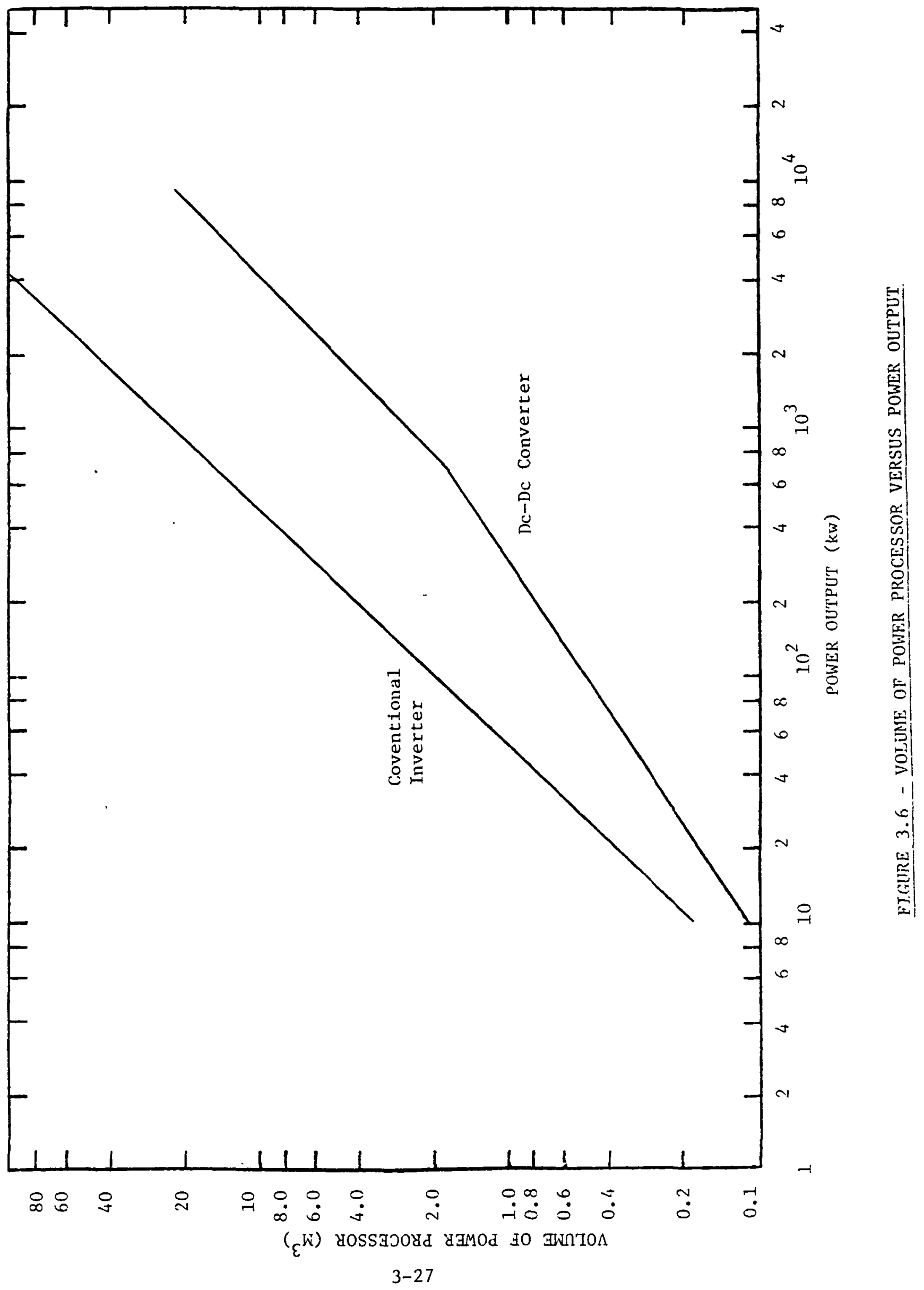




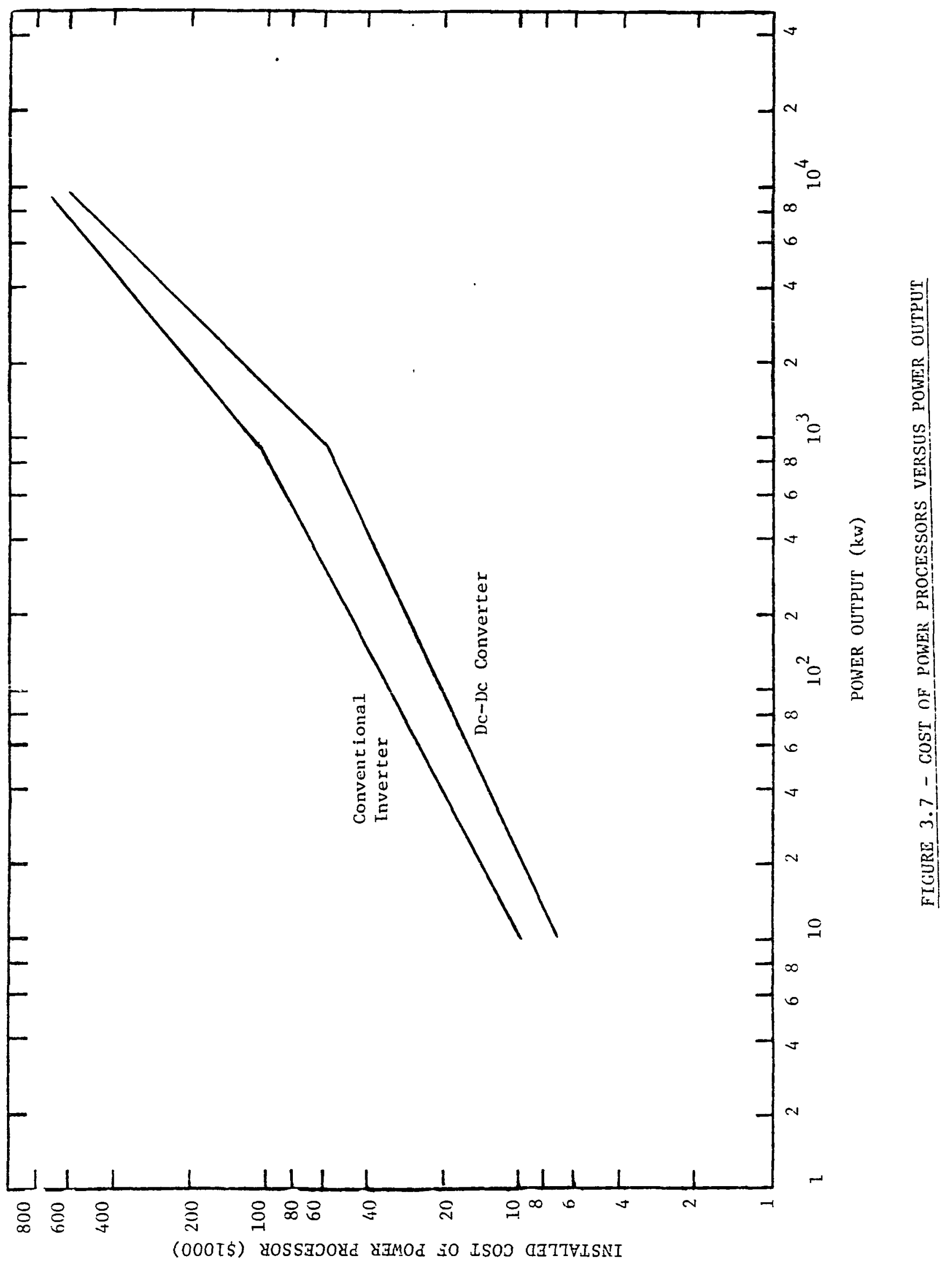


Since two variables are involved, the heat flow to be transferred $(Q)$ and the temperature differential $(\Delta \mathrm{T})$ across which that heat is to flow, it is not possible to characterize heat recovery heat exchanger design characteristics as a simple function of system output. Accordingly, the heat recovery heat exchanger system is not modelled in the same functional form as the other system considered above. Rather, basic data is developed for estimating the weight, volume, and cost of such heat exchangers on a case-by-case basis. The key parameters used and some example values of those parameters are found in Table 3.9 (Reference $\mathrm{K}$ ).

\subsubsection{Assembly of Complete Fuel Cell Power System}

In order to generate data describing the weight, volume, efficiency, and capital cost of a complete fuel cell system using the data base described above, it is necessary to specify three properties of that fuel cell system:

- The modules of which it is to be constituted.

- Power output capacity in $\mathrm{kW}$.

- The number of full-power equivalent hours of fuel storage required.

Details of fuel cell system characterization using this data base are provided in Appendix A.

\subsection{CONVENTIONAL POWER SYSTEMS}

\subsubsection{Systems Considered}

Weight, volume, efficiency, and cost of the following conventional power systems were evaluated for comparison with data developed on fuel cell power systems:

- Diesel engines, with and without generators,

- Gasoline engines, without generators,

- Gas turbines, with and without generators,

- Batteries (to be used in conjunction with $D C / D C$ converters and electric motors to product shaft power).

Steam-based power systems, the dominant conventional power system in some very large applications (notably oceangoing ship propulsion), were not characterized. They were omitted because it was judged that the fuel cell with its premium fuel requirement would not be able to compete in any application where a solid fuel-or residual oil-based steam power system might be used (see Section 5). 

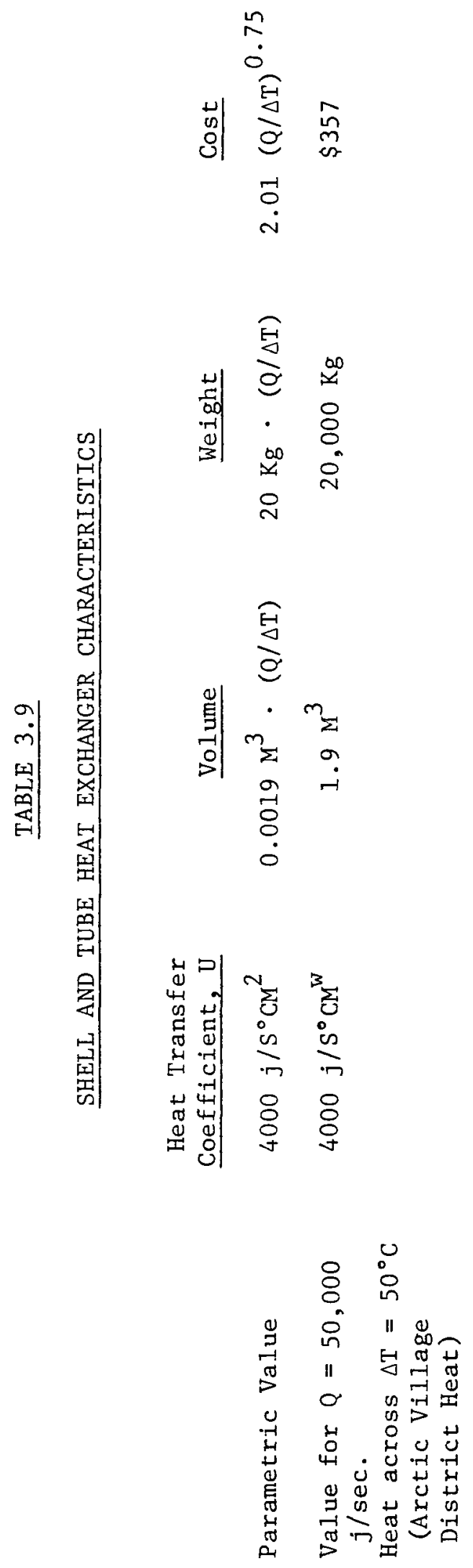
Weight, volume, efficiency, and cost data were developed for two classes of diesel engines (References $\mathrm{L}, \mathrm{M}$, and $\mathrm{N}$ ):

- High speed diesels, such as those typically found in sizes of a few hundred kilowatts or less operating at $1,800-3,600$ rpm, burning DF-1 or DF-2, depending on climate and season.

- Medium speed diesels, such as found in locomotives, available in capacities up to approximately $6 \mathrm{MW}$, burning railroad diesel fuel (a heavy, relatively low-quality diesel fuel).

So-called low-speed diesels were not characterized, since they are not the conventionally used system in any of the applications considered here. As noted previously, it was necessary to characterize all diesel systems with and without electric power generators, since some applications using each diesel system require generators and others do not.

Two gasoline engines were characterized (Reference P):

- A so-called low-efficiency gasoline engine with an efficiency of $15 \%$.

- A so-called high efficiency gasoline engine with an efficiency of $21 \%$.

No data were developed for gasoline engines with generators. Preliminary review based on system data excluding generators indicated that a dieselbased system would be preferred to a gasoline engine system in any application in which the fuel cell might be considered to be viable technically; thus, gasoline-electric systems were never characterized. This is not surprising, since the diesel engine enjoys the same eiconomic advantage over the gasoline engine that the fuel cell enjoys over both, namely fuel efficiency. However, the gasoline engine's advantages over the diesel engine--lower weight, volume, and cost--must be relatively unimportant in an application in order for the heavy, bulky, expensive fuel cell to be viable in that application.

Design characteristics of industrial gas turbines (without generators) were also evaluated, since they are the conventional systems used in some applications identified in Task 2 (References $\mathrm{N}$ and Q). Preliminary evaluation of applications for phosphoric acid fuel cells eliminated all of these applications from consideration. This is not surprising, since the advantages offered by the gas turbine are all deficiencies of the phosphoric acid fuel cell:

- Low volume,

- Low weight,

- Low capital cost, and

- Waste heat availability at or above $550^{\circ} \mathrm{C}$. 
By contrast, the fuel cell's principal advantages, fuel-to-electricity efficiency and cleanliness, are notable deficiencies of the gas turbine systems.

Several applications identified in Task 2 and studied further in Tasks 3 and 4 utilize batteries in conventional systems. Accordingly, lead acid batter-powered system design characteristics were developed (References $R$ and $S$ ).

\subsubsection{Premises of Data Development}

The energy conversion systems were characterized based on publicly available information. Weight, volume, and efficiency were taken from information supplied by the vendors themselves (for all system components except fuel storage). This data reflected characteristics of long-lived (approximately $10^{5}$ hours) stationary skid-mounted systems.

System costs (exclusive of storage) were taken from the literature. These costs reflect those of a complete installed long-lived stationary system.

Each system (except the battery, which acts as its own energy storage) will require energy storage, just as will the fuel cell systems. In order to assure consistency, weight, volume, and cost of conventional storage systems are estimated from the same basic data as for PAFC fuel storage systems.

\section{3 .3 Results}

Table 3.10 provides efficiencies, weights, volumes, and costs of some example conventional systems for production of $1000 \mathrm{~kW}$ of AC power with eight full power hours of energy storage. Note that high speed diesels and gasoline engines are not included, since they are not generally applied at this scale. Complete data on all conventional systems considered here is found in Appendix A.1.

Note the efficiency listed for the battery system. It'is a complete cycle efficiency defined as:

$$
\text { Efficiency }=\frac{\text { AC Power Discharged }}{A C \text { Power Consumed in Charging }}
$$

Al1 other system efficiencies are defined as:

$$
\text { Efficiency }=\frac{\mathrm{AC} \text { Power Generated, } \mathrm{kW}}{\text { Higher Heating Value of Fuel Consumed, } \mathrm{Kj} / \mathrm{Sec}}
$$


TABLE 3.10

CONVENTIONAL POWER SYSTEM SAMPLE DATA

$1000 \mathrm{~kW} \mathrm{AC} \mathrm{Plant,} \mathrm{Eight} \mathrm{Hours} \mathrm{Energy} \mathrm{Storage}$

\begin{tabular}{ccc} 
System & $\begin{array}{c}\text { Medium Speed } \\
\text { Diese1 }\end{array}$ & $\begin{array}{c}\text { Industrial Gas } \\
\text { Turbine }\end{array}$ \\
\cline { 2 - 3 } Weight, Kg & 20,400 & 9,100 \\
Volume, M & 66 & 20 \\
Cost, $\$ 1000$ & 840 & 570 \\
Efficiency, \% & 33 & 26
\end{tabular}




\subsection{COMPARISON OF PAFC AND CONVENTIONAL POWER SYSTEMS}

\subsubsection{Use of the Hardware Data Base}

The Hardware Data Base described here was developed for a specific purpose: comparative evaluation of PAFC and conventional systems for specific applications. Some additional guidance is required to ensure appropriate use for this purpose. Furthermore, data should not be taken out of the context of this analysis for general use in estimation of design characteristics of conventional systems in absolute terms.

First, it must be noted that design characteristic data developed here are for fully engineered, installed, permanent stationary systems. Data deyeloped here was in all cases for longrliyed systems which could be expected to operate at least as long as the life of a cell stack: 40,000 hours. In actual practice, most of these systems exhibit lifetimes exceeding 100,000 hours. The weights and volumes considered here include allowance for packaging and a chassis for supporting the system as it might be placed on a concrete slab, railroad ties, etc. Such weights, volumes, and costs do not in general reflect characteristics of components which would be selected for installation in vehicular systems. Weights and volumes typically quoted in the literature for vehicular systems are for bare engine components.

Similarly, costs considered here include allowance for a completely engineered installation, including controls, construction labor, indirect construction costs, etc. Such costs do not reflect those which are common1y attributed to components chosen for installation in a vehicle. Development of performance characteristic data for such long-lived, stationary systems includes allowance for elements such as chassis and packaging weight, volume, and cost, and installation engineering and labor costs, which should be quite similar in absolute terms for all systems considered here. By subtracting the weight, volume, or cost of one from the other, their impact is cancelled with the resulting weight, volume, or cost differential accurately reflecting the difference between the two bare component systems. These differentials are then used in evaluation of use of a phosphoric acid fuel cell system.

For example, in evaluating whether or not a PAFC system will conform to allowable weight or volume in a vehicular application, it is necessary to compare the difference between phosphoric acid fuel cell and conven r tional system weight or volume determined from the Hardware Data Base with what is considered to be the allowable increment in weight or volume over that currently accounted to conventional system in actual practice. Thus, it is estimated that a locomotive using a $2237 \mathrm{~kW}$ diesel generator could carry an additional 18 tonnes of weight without inhibiting locomotive performance. From the Hardware Data Base, it can be calculated that the difference between the conventional diesel electric system and a $500 \mathrm{kPa}$ PAFC system based on methanol would be 12.6 tonnes, which is within this weight allowance. It is not meaningful, however, to compare 
directly the weight projected for the PAFC system in the Hardware Data Base ( 52.7 tonnes) with the actual weight of the diesel electric system installed in such a locomotive ( 34.5 tonnes), since the PAFC system weight was developed for a stationary system while the diesel was for a vehicular system.

Second, it should be noted that the fuel cell system costs projected in the data base are inappropriate for mass produced systems. They reflect current prototype costs using current technology. Prototype costs are projected in order to determine whether or not any application can be identified which could bear such costs, or to estimate the degree of cost reduction required for economic viability in a given application. In Chapter 6, estimations will be made of learning curve effects which might be manifested in manufacturing operations associated with each application evaluated. Cost reductions will, of course, vary among possible applications depending upon the production rate which might be expected to be associated with such applications.

\subsubsection{Fuel Use and Fuel Efficiency}

The principal advantage that fuel cells offer over conventional fuel based alternatives is greater fuel efficiency. As a more efficient means of producing electricity or shaft power, the fuel cell will generally use less fuel, thus saving on fuel costs in comparison with diesel or other conventional systems.

Table 3.11 lists efficiencies of several representative candidate $1000 \mathrm{~kW}$ fuel cell and conventional systems on three bases:

- Efficiency of energy utilization at the point of end-use.

- Efficiency of energy utilization taking account of process steps continuously or periodically conducted to service the end-use in the immediate vicinity of the end-use (production of hydrogen from methanol, recharging of batteries) i.e., the "site efficiency."

- Efficiency of energy utilization based on primary energy resources consumed; two values shown in each case based on the current fuel source and on perspective future fuel sources.

Table 3.12 lists the fuel-to-fuel conversion efficiencies used in this analysis to evaluate resource utilization efficiency. 


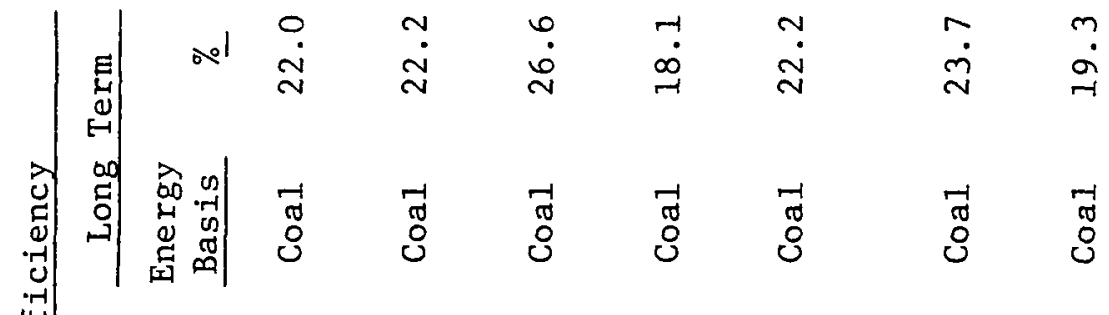

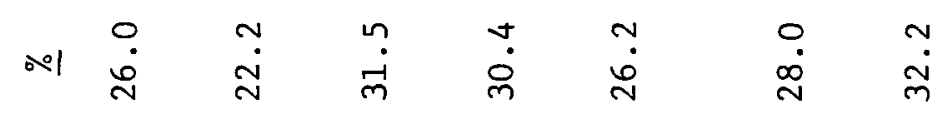

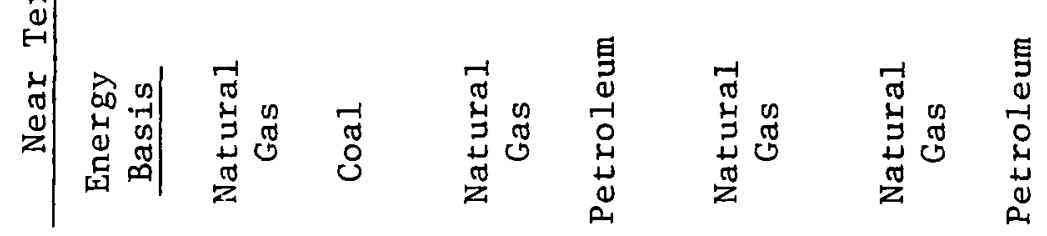

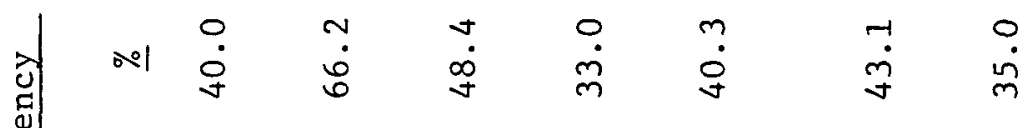

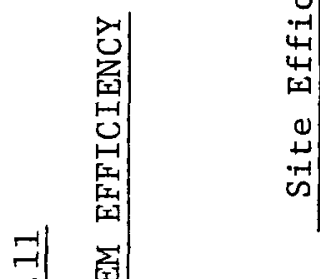

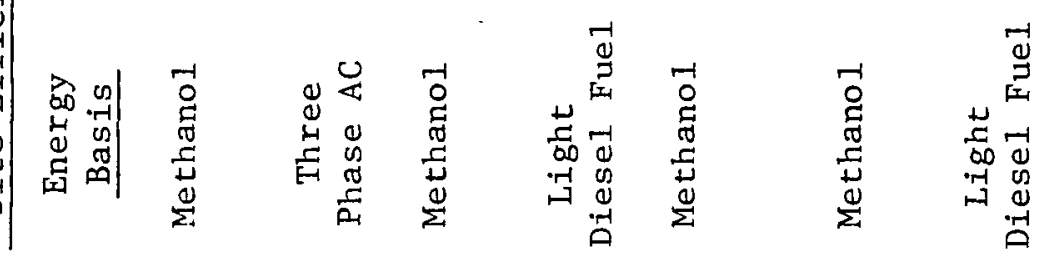

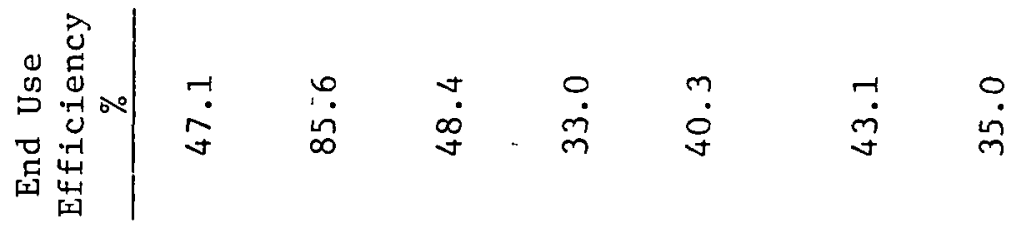

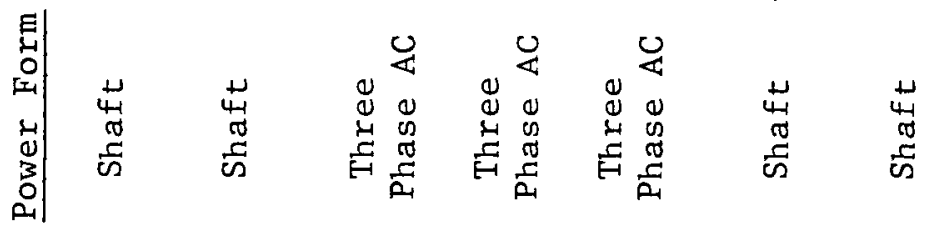

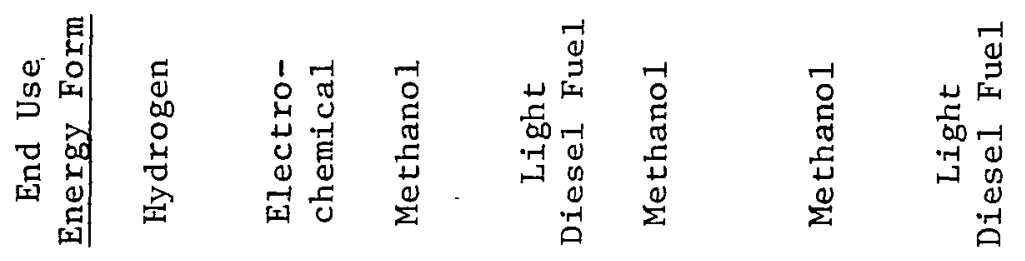

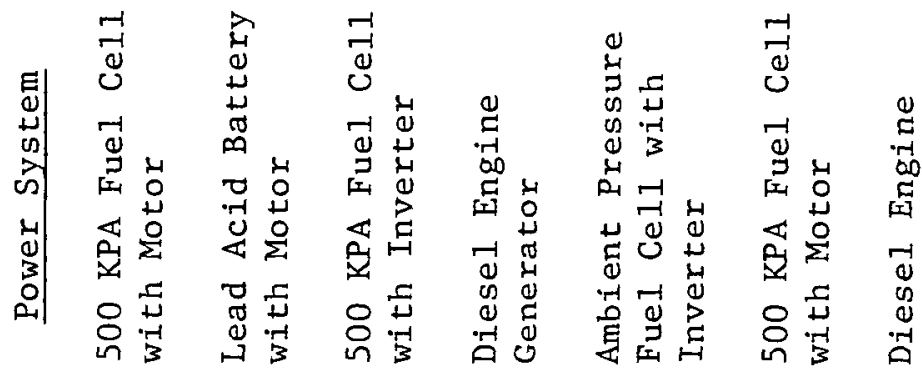


TABLE 3.12

ENERGY-TO- ENERGY CONVERSION EFFICIENCIES

\begin{tabular}{|c|c|c|}
\hline $\begin{array}{c}\text { Inititial } \\
\text { Energy Form }\end{array}$ & $\begin{array}{c}\text { Fina1 } \\
\text { Energy Form }\end{array}$ & $\begin{array}{c}\text { Conversion } \\
\text { Efficiency, } \%\end{array}$ \\
\hline Petroleum & Light Diese1 Fuel & 92 \\
\hline Petroleum & Electricity & 32 \\
\hline Methanol & Hydrogen & 85 \\
\hline Natural Gas & Methane & 100 \\
\hline Natura1 Gas & LPG & 100 \\
\hline Natural Gas & Methanol & 65 \\
\hline Biomass & Ethanol & 26 \\
\hline Coal & Methanol & 55 \\
\hline Coa1 & Methane & 60 \\
\hline Coal & LPG & 55 \\
\hline Coal & Light Diesel Fuel & 55 \\
\hline Coal & Electricity & 33 \\
\hline
\end{tabular}


As can be seen, battery systems are the most efficient systems at the point of end-use (site-efficiency), followed by fuel cells, then by diesels. Taking account of resource utilization, both based on current and future resource bases, it can be seen that the fuel cell system offers comparable or greater efficiency of resource utilization than any of the other systems, including batteries.

Another implication of efficiency comparison is readily apparent. Fuel cells compare much more favorably with conventional systems as a source of electricity than as a source of shaft power. A diesel engine naturally generates shaft power. In order to generate electricity, a generator must be added to the diesel engine, which generator is not itself perfectly efficient. Thus, efficiency of electric power generation via diesel is less efficient than shaft power generation. With the fuel cell, by contrast, the natural product is electricity. To produce shaft power, it is necessary to add an electric motor, which is not perfectly efficient. Thus, the fuel cell can be expected to look more favorable in applications in which the required energy form is electricity. This may be in utility type applications, such as remote village power or in applications where dynamic breaking necessitates use of traction motors to provide shaft power as in a railroad locomotive.

\subsubsection{Other Potential Advantages}

The phosphoric acid fuel cell also offers other advantages which may be important in specific applications. These include:

- Very low levels of air pollutant emissions.

- Very low noise levels.

- Probable high reliability and low maintenance requirements.

- Potential for safe, cool operation.

Comparison with other means of achieving these ends shows that some of these advantages are more significant than others.

The PAFC is capable of limiting emissions of oxides of nitrogen, particulate matter, sulfur dioxide, and carbon monoxide to extremely low levels. For many purposes, however, the extremely low rates of emissions are of relatively little interest. They could be $1-4$ orders of magnitude greater and still be less than or equal to those of conventional fuel burning engines. It cannot be expected that emission limits will be mandated for any large-scale terrestrial application which would require such livels of cleanliness.

The significance of the cleanliness is expected to be manifested in applications in which emissions of pollutants result in direct, economically quantifiable consequences. This suggests a class of 
applications: replacement of conventional power systems operated in environments which require ventilation. In such situations (i.e., mines), they could command a premium price, vis-a-vis diesels or compete directly with heavy, bulky, expensive battery systems.

The quiet operation of the fuel cell is not expected to be a significant factor in its commercial future. While it is true that the fuel cell is a quiet system, it is not silent. A complete fuel cell system necessarily includes a blower, pumps, etc. If noise is a concern, this can readily be limited with a diesel using existing, inexpensive techniques. If total silence is required, a fuel cell cannot compete with a battery as an essentially silent supply of power.

The PAFC may exhibit higher reliability and require less maintenance (in particular much less unscheduled maintenance) than diesels due to the much less demanding operating conditions prevalent in fuel cell systems. Such patterns of high reliability/lower maintenance requirements can be expected to develop as fuel cell systems mature. They can be expected to be of great importance in remote power applications.

It should be possible to design a fuel cell which reliably exposes its environment (exclusive of oxidant air intake) to no temperature greater than approximately $80^{\circ} \mathrm{C}$. This capability may make the fuel cell acceptable for use in an important environment in which diesel engines cannot generally be used (i.e., underground coal mines). 
A. United Technologies Corporation, "40-KW Field Test Power Plant Modification and Development, Phase I," South Windsor, Connecticut, July 1979, prepared for DOE, NASA, and GRI under contract DE-AC03-77 ET11302.

B. Energy Research and Development Administration, "Request for Proposal No. EC-77-R-01-5018," Washington, DC, February 1977.

C. Benjamin, Thomas G., et al., Handbook of Fuel Cel1 Performance, Institute of Gas Technology, Chicago, Illinois, May 1982, prepared for DOE under contract EC-77-C-03-1595.

D. Huff, J. R., et al., "Fuel Cells for Transportation Applications, Progress Report, January 1 - December 31, 1981," Los Alamos Nationa1 Laboratory, Los Alamos, New Mexico, June 1982, LA-9387-PR.

E. Meyer, A. P., et al., "Parametric Analyses of $1.5 \mathrm{KW}$ Methanol Fuel Cell Power Plant Designs," United Technologies Corporation, South Windsor, Connecticut, May 1978, prepared for U.S. Army Mobility Equipment Research and Development Command under contract DAAK7077-C-0195.

F. Buggy, J. J., et a1., "Effect of Alternate Fuels on the Performance and Economics of Dispersed Fuel Cells," EPRI EM-1936, Westinghouse Electric Corporation, Large, Pennsylvania, January 1982.

G. Pouchot, W. D., et al., "U.S. Air Force Fuel Cell Applications Analysis," AFWAL-TR-82-2004, Westinghouse Electric Corporation, Pittsburgh, Pennsylvania, January 1982.

H. Draft of Final Oral Report Notes, "Investigation of a Family of Power Conditioners Integrated into the Utility Grid," United Technologies Corporation, 1981, for DOE under contract DE-AC02-79ET29355.

I. Private communication.

J. Reliance Electric Company, private communication.

K. Process P1ant Construction Estimating Standards, Volume 4, Richardson Rapid System, 1980.

L. Detroit Diesel Engines, Electric Set Mode1s, General Motors Corporation, Detroit, Michigan.

M. Electro-Motive Division, Electro-Motive Power Specifications: Model 999 System, General Motors Corporation, LaGrange, Illinois. 
N. Knightly, W. F., "Cogeneration Technologies Alternatives Study (CTAS)," Volume VI, Part 1, Section B, NASA CR-159770, General Electric Company, Schenectady, New York, 1980.

P. Kidd, R., "Potential for Spark Ignition and Diesel Engines, Engine Catalog and Performance Analysis," DOT-TSC-NHTSA-79-39, U.S. Dept. of Transportation.

Q. General Electric Company, private communication.

R. O'Conne11, L. G., et al., "Energy Storage Systems for Automobile Propulsion: Final Report," UCRL-53053-80, Lawrence Livermore National Laboratory, December 1980.

S. Electric Power Research Institute, "Technical Assessment Guide," EPRI P-2410-SR, 1982. 


\subsection{APPLICATION IDENTIFICATION AND CLASSIFICATION}

\subsection{APPLICATION CLASSES CONSIDERED}

The purpose of this task is to identify applications for PAFC which DOE and NASA consider have not yet been or are not currently being pursued with an adequate level of effort. To serve this purpose, application identification was pursued based on the proposition that all applications should receive consideration except:

- Large electric utility applications analogous to the $4.5 \mathrm{MW}$ unit now installed on the Consolidated Edison system;

- On-site total energy applications similar to those to be served by the $40 \mathrm{KW}$ units being sponsored by DOE and others;

- Developed world industrial cogeneration applications;

- Opportunistic use of industrial waste hydrogen;

- Military and space applications;

- Applications which would be served by fuel cells smaller than $10 \mathrm{KW}$.

\subsection{APPLICATIONS LIST GENERATION}

Application identification began as part of proposal preparation. The preliminary list of applications developed at that time is shown in Table 4.1; as can be seen, it included applications such as numbers 19 (fuel considered outside the scope) and 26 (too small) which were eventually excluded based on fully developed study guidelines enumerated in Section 4.1. Subsequent work served to identify new applications and to break down classes of applications shown in Table 4.1 into appropriate subclasses for separate evaluation.

Additional applications were identified and data on application characteristics gathered through four activities:

- Brainstorming meetings;

- Literature search;

- Review of Arthur D. Little's study of potential stirling engine applications;

- Direct contacts with equipment vendors.

Applications are reported in this section as they were identified, with one exception: potential applications which were determined to have 
Application Number
Industrial

Application Class

Transportation

Mining/Construction

Food and Agribusiness

Other Remote Power Applications
Petroleum Products Tankers

Crude 011, LNG, and LPG Tankers*

Submersible Tankers

Submersible Research Vessels*

Urban Buses*

Urban Trucks and Vans

Rail road Locomotives*

Above Ground Rail Rapid Transit

Tow Boats

Mobile Atr Compressors*

Remote Stationary Power Gereration*

Underground Stationary Power Generation*

Shut tle Cars*

Personnel and Supply Transport

Diesel-powered Trackless Loading, Haulage, and Drilling Equipment*

Welding Power Supplies*

Oil and Gas Production Platforms*

Pipeline Puroping and Compressor Stations*

Process Plants with Byproduct $\mathrm{H}_{2}$

Portable Process Plants*

Irrigation Pumping*

Remote Food Processing (especially year-

round operations such as milk and livestock processing, oflseed milling, and fish processing) *

Total Energy Systen for Ethanol Production*

Total Energy System for Water Desalination Plants*

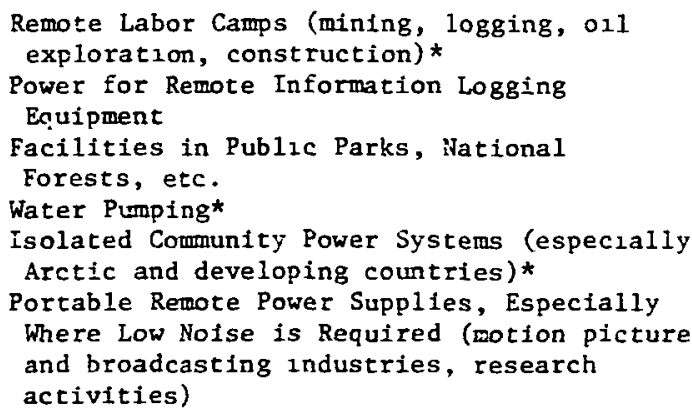

*Significant export potential. 
power requirements too small for consideration in this study are deleted from all lists presented in this report. The final consolidated application list is presented in Section 4.3 below.

\subsubsection{Brainstorming Meetings}

Fuel cell applications were identified in a series of meetings with members of Arthur D. Little, Inc.'s professional staff engaged in work in potential fuel cell application areas. A typical meeting began with recitation of possible applications in this area which had already been identified, together with qualitative information developed in Task 1 characterizing the benefits, disadvantages, and general characteristics of fuel cells and an explanation of how the fuel cell was expected to offer advantages in each such application. The discussions that followed served to clarify understanding of previously identified applications, develop information on closely related applications, and identify entirely new potential applications. The findings of each session are presented in the following sections.

\subsubsection{Remote Power Applications}

Systems in this category provide electric power in remote areas where conventional line service is not available. Examples are off-shore rigs, construction sites, outposts (such as arctic stations and small islands), and remote villages. Two new applications identified in this meeting which were not shown in Table 4.1 are lighthouse power and power for above ground mineral processing plants. The fuel cell power plant would compete against conventional diesel generators or new power systems such as photovoltaic or wind. Factors that will determine the overall attractiveness of the fuel cell system are fuel type and availability, duty cycle, efficiency, cost, and environmental issues.

\subsubsection{Other Oil and Gas Industry and Related Applications}

Review of remote power application indiciated that activities related to extraction and transport of oil and gas might yield additional PAFC applications. Discussions with research engineers of a major U.S. oil company did serve to identify additional applications. These applications are listed in Table 4.2.

Though undertaken as a brainstorming session, this meeting provided useful insights into possible limits on the applicability of PAFC systems. These included:

- Very large systems which allow for use of a large, relatively low temperature heat sink will allow power generation via a steam cycle. These applications will allow the use of an inexpensive, dirty fuel, such as residual fuel oil (possibly with coal or petroleum coke slurried in it), coal, wood, etc. It will be extremely difficult for a fuel cell, however efficient, to compete in such applications unless extreme cleanliness is required. 
TABLE 4.2

POTENTIAL FUEL CELL APPLICATIONS - OIL AND

GAS EXPLORATION, PRODUCTION, TRANSPORT, AND RELATED APPLICATIONS

Offshore Drilling Rig

Submersible Equipment (Various Sorts)

Coal Slurry Pipeline Pumping Stations

Undersea Mining Equipment

Methanol Tankers 
- The critical factor in competition between fuel cell and battery systems is mission length. In many cases where the battery is the only currently feasible power source, commercial use of the equipment powered by the battery may be well adapted to mission length constraints imposed by the battery; utility advantages offered by the fuel cell, though substantial, may be difficult to quantify.

An additional insight generally applicable to the remote power field is that the fuel cells supposed advantages of high fuel efficiency and very high reliability suggest investigation of the same sorts of applications which are targeted for early use of photovoltaic power. This naturally suggests review of such applications for use in the Arctic, where photovoltaic power is not a viable alternative year round. Such investigation led to identification of substantial numbers of new potential applications; however, all except arctic village power fell below the minimum size (10 KW) specified for this study.

\subsubsection{Food and Agribusiness}

Irrigation pumping and water distribution is the largest energy user in agriculture. Domestic systems use natural gas or diesel power. In developing countries, diesels are used for irrigation. Since fuel cost is high, efficiency is important and the fuel cell could provide some benefit.

Food processing in remote locations (land and sea) offers real potential for fuel cell power. Electricity is required for refrigerating or freezing and heat is needed for cooking, pasturizing, etc. Specific applications mentioned in the meeting were fish processing, poultry, and dairy. A concept that appears very attractive is integration of the fuel-cell-powered processing plant in remote agricultural areas with a biomass plant to produce fuel for the cell. An advantage of the fuel cell over other power sources may be its adaptability for use of poor quality gases and alcohols.

A variation on the above application is the use of a fuel cell to supply electric power to irradiate grain for insect control. This would be especially useful in developing countries.

Another variation would be to use a fuel cell as the major power source in large operations such as sugar refining in countries where conventional fuels are expensive and a biomass/fuel cell system would have cost advantages.

Table 4.3 lists the applications generated in this meeting.

\section{$\underline{4.2 .1 .4}$ Transportation}

As shown in Table 4.4, several applications were identified for phosphoric acid fuel cells in the transportation sector. However, it was concluded that further analysis will probably reveal that fuel cell 
TABLE 4.3

POTENTIAL FUEL CELL APPLICATIONS -

AGRICULTURAL AND FOOD PROCESSING

Grain Drying

Lumber Mills

Tractors

Farm Machines

Logging Machines 
TABLE 4.4

POTENTIAL FUEL CELL APPLICATIONS - TRANSPORTATION

\author{
Passenger Cars \\ Highway Trucks and Buses \\ Long Haul Railroad Locomotives \\ Switching Locomotives \\ Taxis \\ Yachts \\ Rail Maintenance Vehicles \\ Construction Vehicles \\ Cruise Ships \\ Mobile Refrigeration Equipment
}


use in vehicles is not a realistic possiblity except in certain applications, such as vehicles used in hazardous environments and railroad locomotives. The major technical disadvantages of fuel cells is weight, which is estimated to far exceed competing vehicular power sources. Also, higher capital costs expected for PAFC, even with mass production, can only be recouped economically over long lives, at least 40,000 operating hours. In many vehicular applications, this substantially exceeds vehicle life.

Fuel cell use in aircraft was eliminated from consideration because of the low power density of fuel cells compared to gas turbines, problems related to the development of lightweight, high power electric motors, and the requirement for a high quality fuel for an air-worthy fuel cell.

\subsubsection{Mining}

The general consensus at this meeting was that there is a real potential market for fuel cells in the mining industry. According to industry experts, the rock mining industry is looking for technology that would eliminate diesel-powered vehicles in mines. A basic problem is that the carbon monoxide and hydrocarbons emitted by diesels requires that mines be highly ventilated. Use of a cleaner power plant would greatly reduce the ventilation required. The consensus was that the fuel cell should be on-board the equipment.

A potentially interesting application in surface mining is to power large (approximately 90 tonne) trucks. These vehicles currently use diesel generators combined with individual wheel traction motors. A fuel cell using diesel fuel could replace the diesel/generator combination in this application.

The use of fuel cells in underground coal mines poses a minor technical problem. The power system could not be allowed to expose the coal dust-laden air to a temperature higher than approximately $120^{\circ} \mathrm{C}$. Design of such a system poses no fundamental problems, and would allow PAFC use in competition with batteries and cable power systems.

Surface processing of run-of-the-mine minerals generally requires significant electric power for milling, pumping, drying, etc. A PAFC may be attractive as a power source for such plants located at sites remote from the power grid.

Table 4.5 lists the applications identified.

\subsubsection{Literature Search}

Arthur D. Little, Inc, reviewed available literature in order to expand the list of fuel cell applications and collect any available information on these and other applications identified in Task 2. The literature search included thorough manual review of various scientific and technical indices and accessed several computerized retrieval systems. No additional applications were found from the literature search; however, 
TABLE 4.5

POTENTIAL FUEL CELL APPLICATIONS - MINING

Underground Rock Mines

Load Haul Dumps (LHDs)

Digging Equipment

Locomotives

Surface Mining

Smal1 Hauling Equipment

Large Hauling Equipment

Smal1 Digging Equipment

Large Digging Equipment

Underground Coal Mining

Personnel Carriers

Continuous Mining Equipment

LHDs

Long-Wall Equipment

Locomotives 
information was gathered for subsequent use in the screening of applications in Task 3 and in the more detailed economic evaluations conducted in Task 4 .

Appendix $B$ is the listing of articles with abstracts which contain reference to fuel cell systems and fuel cell applications in this project's area of interest. These articles were then procured and reviewed. Appendix $C$ summarizes the findings from the review of key articles.

\subsubsection{Other Sources}

In addition to the idea generation meetings and the literature search, other sources used to expand the list of applications were a study of stirling engine applications done for NASA Lewis by Arthur D. Little, Inc., and discussions with industry and government contacts. This list of additional applications identified is shown in Table 4.6 below.

\section{TABLE 4.6}

POTENTIAL FUEL CELL APPLICATIONS - MISCELLANEOUS

Recreational Vehicles

Indoor Forklift Trucks

Emergency Industriai Power

\subsection{APPLICATIONS LIST}

The complete list of applications for phosphoric acid fuel cells identified in Task 2 is presented as Table 4.7. The applications are grouped into broad categories based on a particular industry or general function. This list represents all applications listed in Section 4.2. All applications separately listed there do not appear explicity, owing to some consolidation of applications which are expected to have substantially. the same operating requirements, economic contexts of use, etc.

\subsection{APPLICATION CLASSIFICATION}

To facilitate evaluation of this rather lengthy list of applications, an application classification system was developed. This system classified applications according to those power system characteristics which are of primary importance in evaluating PAFC applicability. A11 systems sharing the same power system characteristics are grouped together in a class, allowing subsequent evaluation of fuel cell use class by class, rather than application by application. Data was developed on each application which would be adequate to classify it; no more exact or detailed information on each application was developed at this point. 
FUEL CELL APPLICATIONS

\section{Electrical Power Generation}

a. Quiet electrical power generation for recreation vehicles, mobile homes, etc.

b. Lighthouse applications (propane powered).

c. Short-term underwater power plants.

d. Emergency and standby electric power (hospital, industry).

e. Offshore oil/gas drilling rig.

f. Offshore oil production platform.

g. Remote power for entertainment industry.

2. Non-Conventiona1 Applications (Remote/Third Wor1d)

a. Rural water pumps.

b. Third world power generation (indigenous fuels).

c. Arctic village power generation.

d. Power generation for food processing - Third World.

e. Power for remote mineral processing plants.

\section{Agriculture}
a. Tractors.
b. Farm machines (self-powered).
c. Logging machines.
d. Grain drying.
e. Lumber mills.
- f. Water desalination plant power.

\section{Mining}

Underground Rock Mines
a. Load haul dumps (LHDs).
b. Digging equipment.
c. Locomotives.

\section{Surface Mining}

d. Small hauling equipment.

e. Large hauling equipment.

f. Small digging equipment.

g. Large digging equipment.

\section{Underground Coal Mining}

h. Auxiliary vehicles inside mines.

i. Continuous mining equipment.

j. Large-wàll equipment.

k. LHDs.

1. Locomotives. 


\section{FUEL CELL APPLICATIONS}

\section{Transportation}

a. Passenger cars.

b. Highway trucks and buses.

c. Distribution van.

d. Mail car.

e. Long haul locomotives.

f. Switching locomotives.

g. Taxi.

h. Total energy system for pleasure boats.

i. Delivery trucks.

j. City buses.

k. Rail maintenance equipment.

1. Above ground rail rapid transit.

\section{Construction}
a. Construction vehicles.
b. Portable welders.
c. On-site power.
d. Portable air compressors.
e. Concrete pumps.

\section{Industrial Applications}

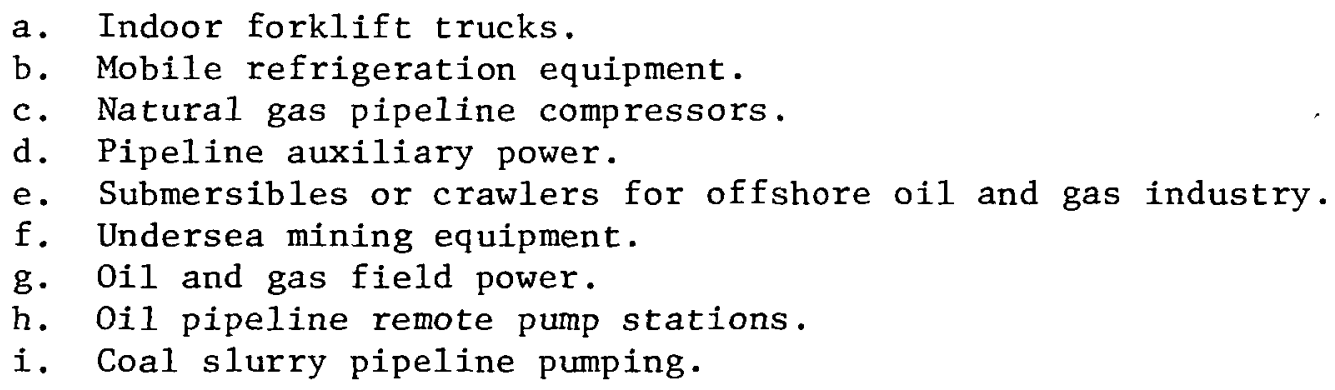

8. Marine Applications (Commercial)
a. LNG/LPG tanker.
b. VLCCs.
c. Petroleum product tankers.
d. Methano1 tankers.
e. Other merchant vessels.
f. Cruise ships.
g. Coastal and inland waterways diesel vessels.
h. Submersible tankers. 
Table 4.8 lists the power system characteristics considered in system classification. This brief list of system characteristics was chosen and other possible classifiers rejected because the classification system which it produces does in fact tend to group applications which are substantially similar into identifiable classes. Furthermore, each such grouping shares characteristics which are critical to evaluation of the applicability of a PAFC power system; to facilitate subsequent eva1uation, quantitative class boundaries are generally selected to correspond to points of transition in fuel cell/conventional system competition, as will 1 be noted below.

The first basis of classification is the operating life expected from the power system. Operating lives are considered to be short if they do not approach the expected 40,000 hour life of a PAFC power section. They are considered long if they equal or exceed this 40,000 hour life. Typical examples of short-lived power systems would be engines used in long haul diesel trucks, taxis, passenger cars, etc. Typical long-lived systems would include most industrial cogeneration systems, utility systems, ship propulsion systems, railroad locomotives, etc. Note that it is unnecessary, for example, to assign a lifetime to long haul trucks of 3,000 hours or 12,000 hours (roughly the extremes encountered in the industry). All that is necessary is to note that tractor life is significantly shorter than 40,000 hours.

A distinction is drawn according to power system capacity, with the division between small and large systems being a capacity of $100 \mathrm{KW}$. This distinction is drawn because systems smaller than $100 \mathrm{KW}$ cannot be expected to utilize a pressurized fuel cell system efficiently and must use an ambient pressure system instead. Larger systems may use the less expensive (and in very large sizes, more efficient) pressurized PAFC. Thus, all other things being equal, PAFC will be more competitive in the larger size class.

The form of power output actually needed in an application is an important consideration in evaluating fuel cell use. Since the fuel cell naturally produces electricity, while most of its conventional competitors (diesels, gas turbines, gasoline engines, etc.) naturally produce shaft power, the comparative advantage of the fuel cell will be relatively greater in those applications where electricity is required than in those applications in which mechanical shaft power is required.

A few applications require either that the power system operate unattended, that it have very low maintenance requirements, or both. Where this is the case, it tends to be a critical consideration in evaluation of power systems. This is accounted in the classification system, to segregate applications where this is critical from otherwise similar applications which place no such requirements on the power system.

Finally, each application is characterized by identification from a list of characteristics which one is the most important for the candidate power system to have. For example, restricted size and weight may 
TABLE 4.8

\section{CLASSIFICATION SYSTEM}

1. Operating Life

- Short: $\ll 40,000$ Hours

- Long: $\geq 40,000$ Hours

2. Capacity (Size)

- Sma11: < $100 \mathrm{KW}$

- Large: > $100 \mathrm{KW}$

3. Form of Power Output

- Electricity

- Mechanical Shaft

4. Low Maintenance/Unattended Operation

- Yes/No

5. Most Important Requirement

- Restricted Size/Weight

- High Fuel Efficiency

- Low Emissions/Noise

- Dirty Fuel Capability

- High Reliability 
be important in light duty vehicular applications, where adding to vehicle weight may offset any efficiency advantage achieved by a more efficient but heavier power system. Simple comparison of power system efficiencies will be the most important factor in power system selection in many applications in which none of the other listed characteristics are of compelling importance, and where annual capacity factors are high. Low emissions of air pollutants and/or noise will be most important only in a very few applications; however, in those in which it is important, it may play a vital role in establishing the viability of a very clean, quiet system such as a fuel cell. By contrast, the amenability of an application to use of a low quality fuel in a steam electric generating system probably indicates that $\mathrm{PAFC}$, with its premium fuel requirement, will not be competitive at all. Finally, a few applications are characterized by the need for a power system with a very long mean time between failures; in such applications, the perceived reliability of PAFC contributes importantly to its commercial viability.

Table 4.9 presents the results of application classification. Table 4.10 displays the characteristics manifested by the applications listed in each class. 
TABLE 4.9

\section{APPLICATION CLASSES}

\begin{tabular}{|c|c|c|}
\hline Class & Application Codes & Description \\
\hline 1 & $1 a$ & RV/Mobile Home Power \\
\hline 2 & $4 h, 7 a$ & Fork Lift/Mine Shuttle Car \\
\hline 3 & $4 a, b$ & Short Lived U/G Rock Mining Equipment \\
\hline 4 & $4 e, 1$ & Long Lived U/G Mining Equipment \\
\hline 5 & $1 f$ & Mobile Generation - Entertainment Industry \\
\hline 6 & $4 i, k$ & U/G Coal Mining Equipment \\
\hline 7 & $5 a, c, d, g$ & Smal1 Private/Commercial Vehicles \\
\hline 8 & $\begin{array}{c}3 a, b, c, 4 d, 5 b, h, \\
i, j, k, 1,6 a, d, e\end{array}$ & Medium/Large Commercial Vehicles \\
\hline 9 & $6 b$ & Portable Welders \\
\hline 10 & $2 e, 3 d, e, f, 4 g$ & Remote Electricity Mining/Agriculture \\
\hline 11 & $4 f, 8 g$ & Coastal/Inland Water Vessels \\
\hline 12 & $4 e$ & Large A/G Mining Trucks \\
\hline 13 & $1 b, 7 d$ & Small, Remote Electric Power \\
\hline 14 & $2 a$ & Small Remote Mechanical Power \\
\hline 15 & $2 b, c, d$ & Medium/Large Remote Electric Power \\
\hline 16 & $7 c, h, i$ & Medium/Large Remote Mechanical Power \\
\hline 17 & $1 e, f, 5 e, f, 6 c$ & Medium/Large Electric Power, Size Restriction \\
\hline 18 & $8 a, b, c, d, e$ & Large Commercial Ships \\
\hline 19 & $1 c, 7 e$ & Small Submersibles \\
\hline 20 & $8 \mathrm{~h}$ & Submersible LNG Tanker \\
\hline 21 & $7 f$ & Undersea Mining Equipment \\
\hline 22 & $7 b$ & Mobile Refrigerators \\
\hline 23 & $7 \mathrm{~g}$ & Oil and Gas Field Electricity \\
\hline 24 & $8 f$ & Cruise Ship \\
\hline 25 & $4 j$ & Long Wall Mining Machine \\
\hline 26 & $1 \mathrm{~d}$ & Emergency Standby Power \\
\hline
\end{tabular}




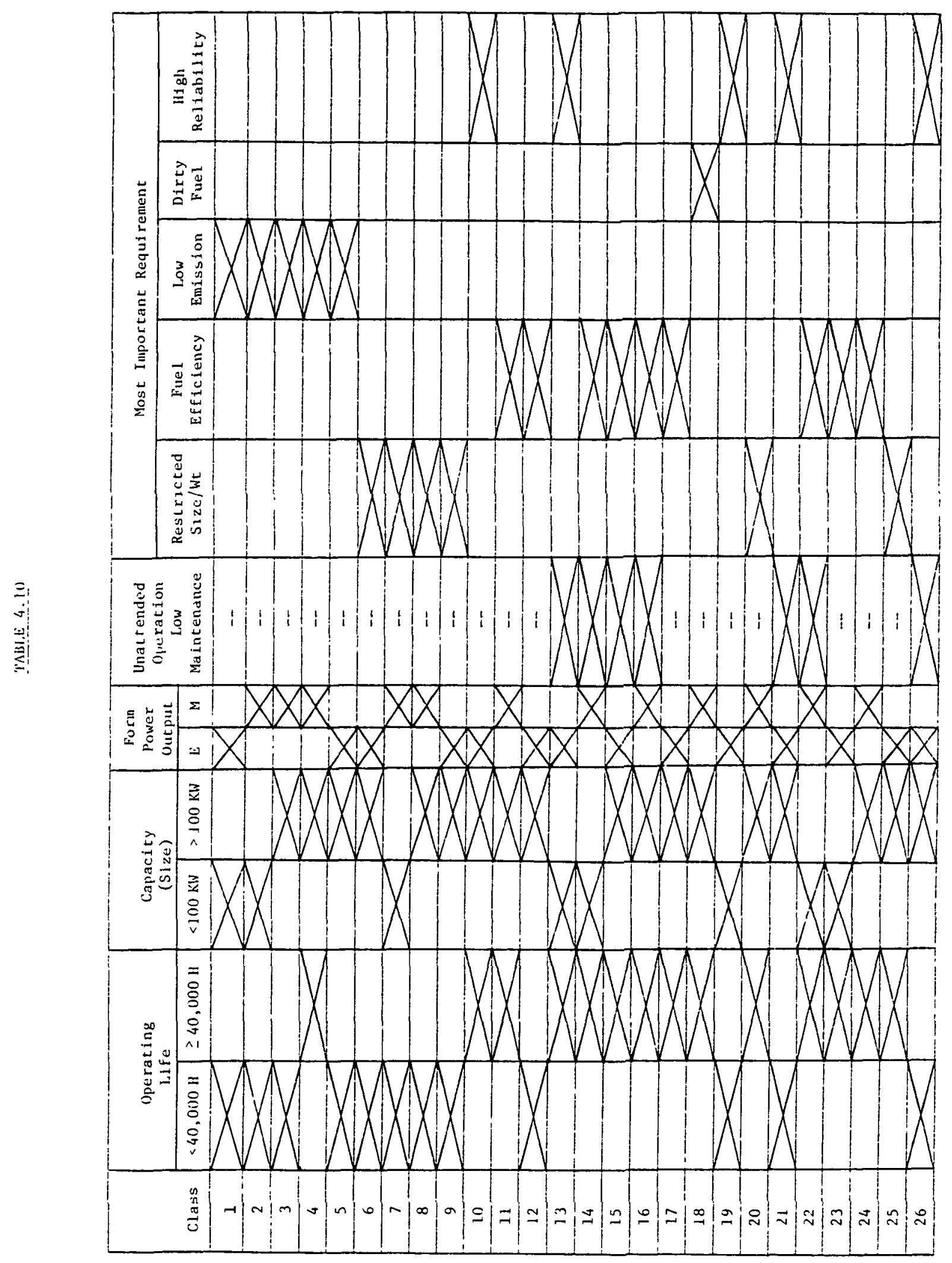




\subsection{TECHNICAL ANALYSIS OF APPLICATIONS}

\subsection{SELECTION OF CANDIDATE APPLICATIONS}

\subsubsection{Comparative Analysis}

Technical analysis of possible candidate applications for use of PAFC began with a rough screening of the application classes identified in Chapter 4. This process was conducted in six steps:

- Elimination of any classes of applications for which phosphoric acid fuel cells are technically unsuitable or for which strong generic economic arguments can be made indicating that another class of system would be preferred;

- Development of a list of power system characteristics which collectively describe a PAFC system and the conventional system of importance here, which characteristics reflect the degree of qualifications of PAFC for use in the applications considered;

- Comparative numerical rating of PAFC vis-a-vis the conventional alternatives based on the power system characteristics, on a scale of 1 to 4 :

- Returning to the application classes, weighting the importance of each power system characteristic for the applications in that class, on a scale of 1 to 4 ;

- Production of a weighted average rating factor for PAFC compared to their conventional competition using the above described weighting and rating factors for application in each class; and

- Review of the weighted rating factors achieved by PAFC in the various application classes, giving consideration to other factors of importance in this study, to offer a candidate list for applications for further study.

The process began with elimination of classes of applications wholly unsuitable for PAFC because of certain fuel cell system characteristics. This was done because the unsuitability would not be adequately reflected in the comparative rating system. The criteria used for elimination were presence of a critical need for fast system startup and capability to make use of a steam power cycle using, a dirty fuel (coal, petroleum coke, wood, residual fuel, etc.). The former consideration eliminated classes 1 and 26 listed in Table 4.9; the latter consideration eliminated class 18 . These classes were not considered further in this study. 
In Chapter 4, applications were classified according to characteristics of the application which bear on the comparative economics of use of various power systems. This process grouped applications into classes within which power system needs are similar. These characteristics do not, however, explicitly describe the power systems themselves. For example, application lifetime refers to desired power system lifetime. Most remote power demands have a lifetime on the order of 100,000 hours. By contrast, a long-haul truck engine with life much longer than 10,000 hours is of little interest, since the tractor upon which the engine is mounted will have reached the end of its useful life during this period. It was necessary to develop a list of characteristics which descrihed a power plant itself but which also characterized the suitability of that power plant for use in an application. The criteria chosen were fuel efficiency, reliability, maintenance requirements, air pollutant emissions, noise emissions, startup rate, volume, weight, and capital cost. These criteria were chosen because collectively they describe the system's technical capability to function in a specific application and address those aspects of the system which will determine the economics of the application.

Next, the remaining classes were reviewed to identify what conventional systems are currently in use. These systems use a variety of internal combustion engines (mostly diesel) producing mechanical power in some cases and electrical power in others, batteries, and a variety of power cable systems. The fuel cell is rated in comparison to each of these four systems (IC engines for electric power output, IC engines for mechanical power output, batteries and power cables) on a scale of 1 to 5 for each criteria identified above. The ratings range from situations in which the fuel cell is much less suitable than the conventional system (rating 1) to situations in which the fuel cell is essentially the same as the conventional system (rating 3) to situations in which the fuel cell is far superior to the conventional system (rating 5). Thus, the fuel cell is rated 5 on efficiency when compared to IC engines for electric power output, but a 4 on efficiency when compared to IC engines for mechanical power output. Similarly, PAFC are rated 5 on size and weight compared to batteries, but 1 on size and weight compared to IC engines for mechanical or electric power output. The complete rating system is presented in Table 5,1.

Based on material gathered in Task 2 as reported in Chapter 4, it was then necessary to weigh the importance of each power system characteristic for application to power systems within each class. Weighting factors range from 1 to 4 as follows:

- 4 - critical

- 3 - very important

- 2 - somewhat important

- 1 - unimportant 


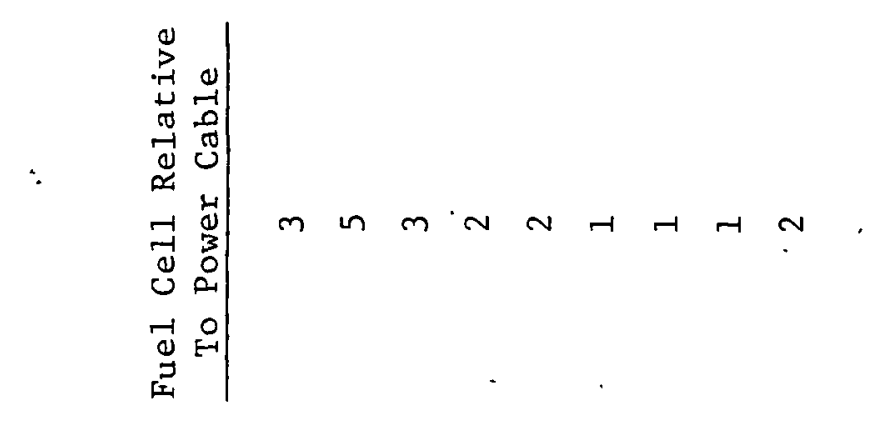

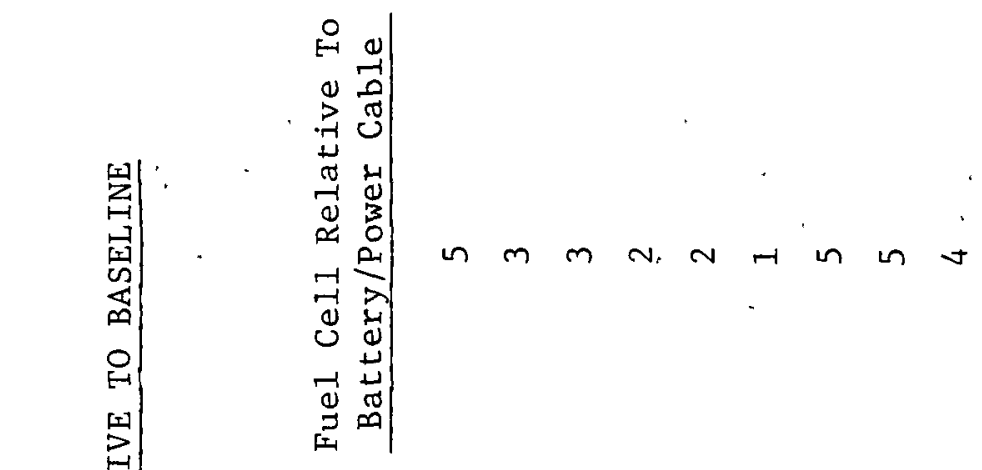

年

勻
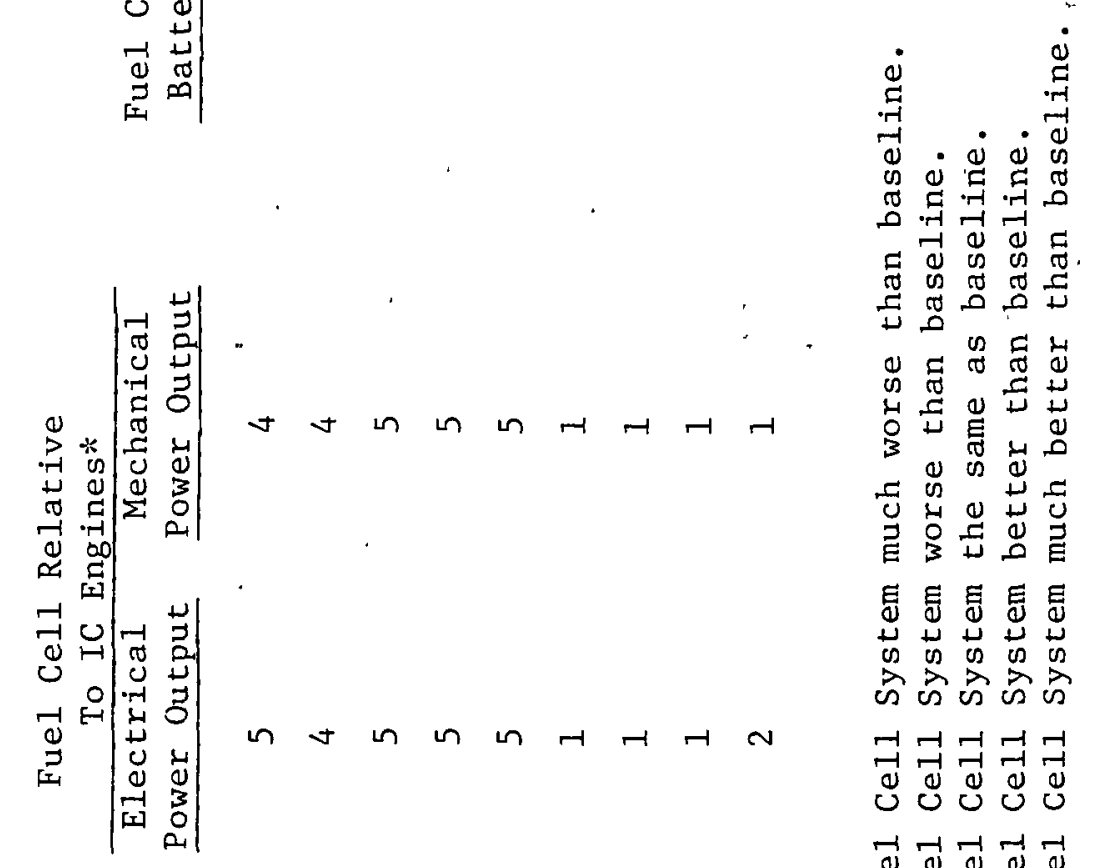

क $0.5 \%$

0 开

त व क क

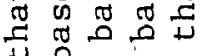

a

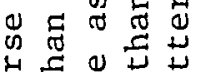

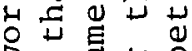

व क क व

의

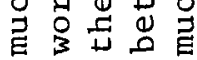

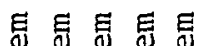

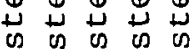

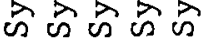

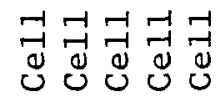

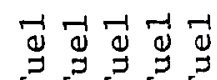

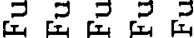

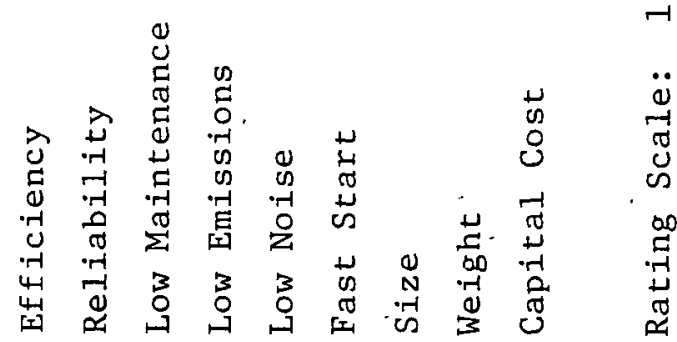


At this point, it was then possible to produce a weighted average rating factor for each application class to serve as a measure of the utility of using PAFC in this application by displacing the conventional system. This was accomplished by taking the rating factors, comparing the PAFC and relevant conventional system from Table 5,1, and multiplying them by the respective weighting factors for a specific application class as displayed in Table 5.2. Examples are shown in Table 5.2. A complete list of the results of such calculations is shown in Table 5.3.

\subsubsection{Application Selection}

Application classes which received the most favorable ratings in the analysis displayed in Table 5.3 are listed in Table 5.4. Seven application classes with overall ratings of 3.2 or greater were selected and a specific application from each such class chosen for further evaluation. In addition, four lower rank classes were selected and an application from each of those classes chosen for further evaluation in order to improve the diversity of the applications considered for further study.

All applications which achieve ratings higher than 3.5 are cases of remote electric power generation. An Arctic village or Third World village power system was chosen to represent large remote electric power generation, and multipurpose oil and gas field power supply was chosen to represent that industry. The sma11 remote electric power class was dropped from consideration because the specific applications which had been identified for inclusion in that class all proved to be too small for consideration in this study (less than $10 \mathrm{~kW}$ ).

Review of applications with ratings between 3.2 and 3.5 also includes several remote power cases. Of these, the class of power for remote mining and agribusiness operation was accepted, with power for a remote ethanol plant chosen as a specific application for consideration. Also selected was small remote mechanical power, with the specific application chosen being that of rural well and irrigation pumps. Rejected were medium to large remote mechanical power and remote power for the entertainment industry. The former was rejected because attractive applications within this class were basically similar to those covered in oil and gas field power. The latter was rejected because the market was considered to be too small.

Other application of classes accepted for further evaluation include: long-lived underground mine equipment, with the mine locomotive being a specific application chosen for further evaluation; coastal and in-land water vessels, with the tow boat being the specific application chosen; and medium to large electric power generation subject to volume restriction, with the railroad locomotive being chosen as the application for further evaluation. Small submersibles and cruise ships were rejected because 

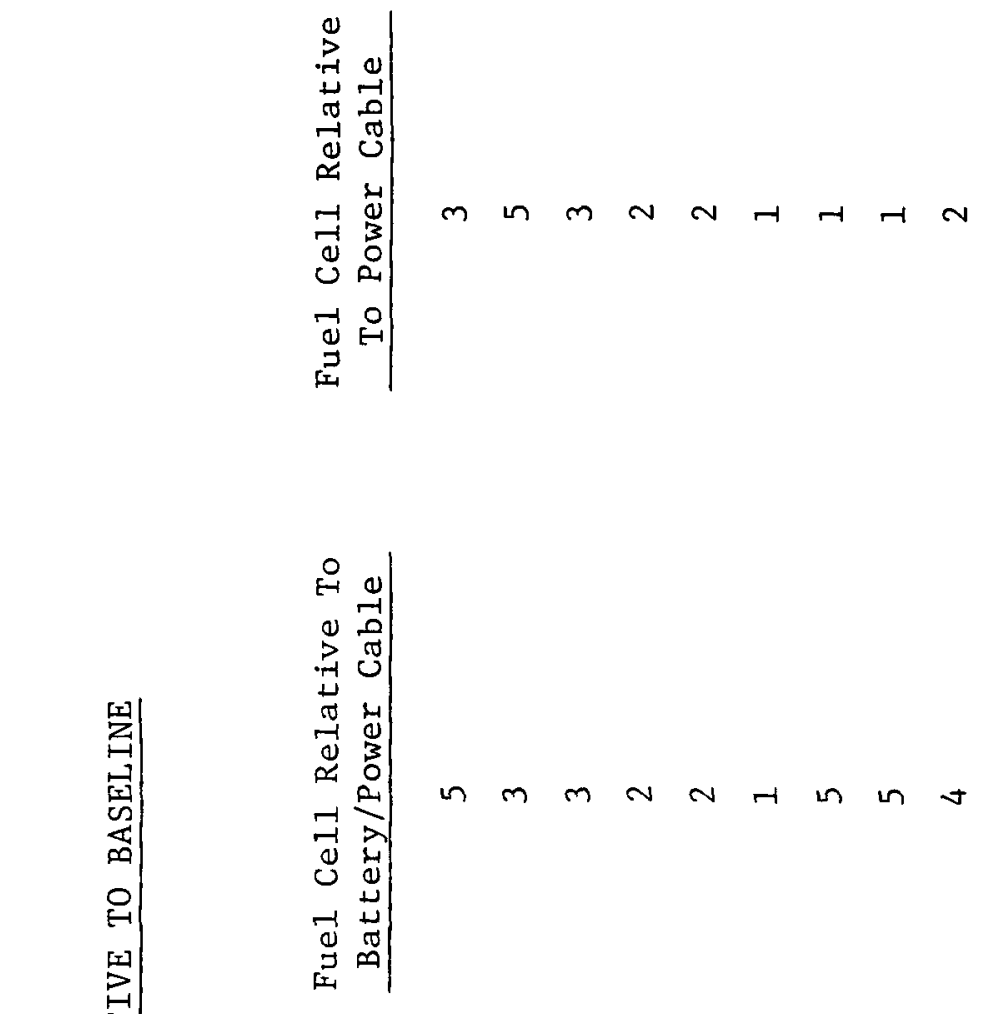

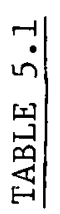

利
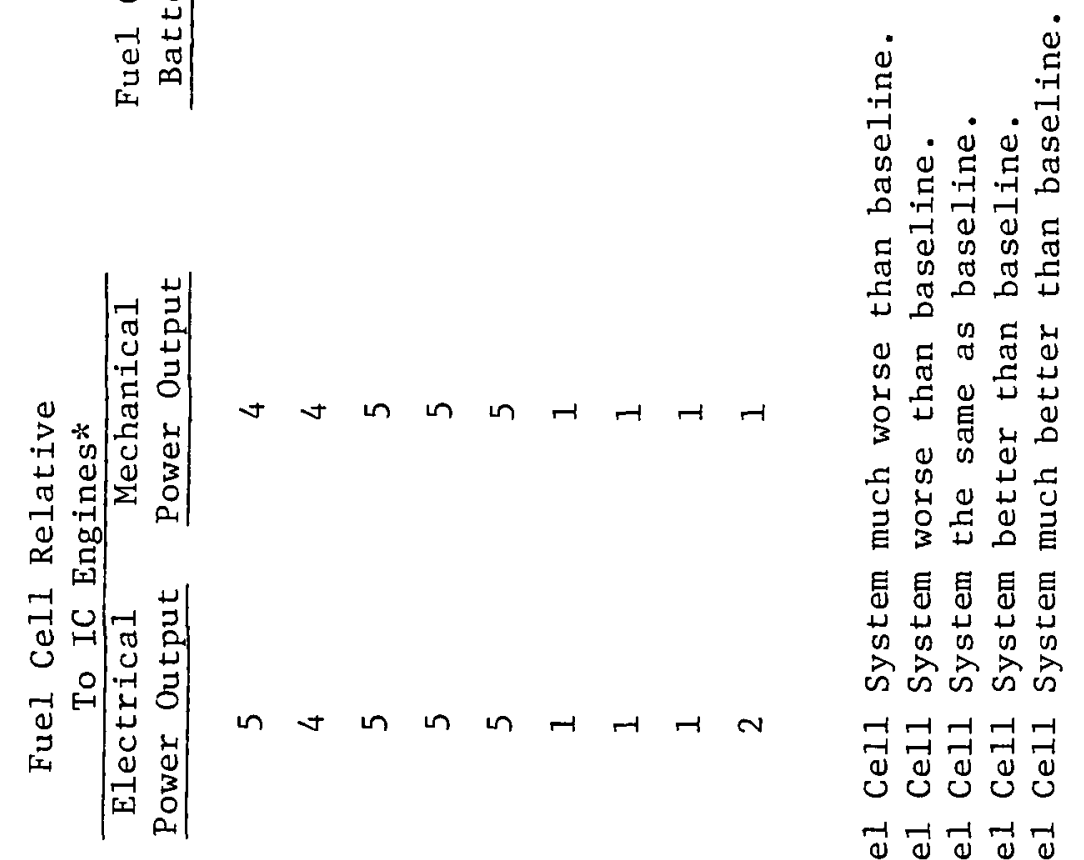

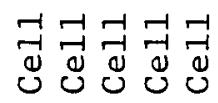

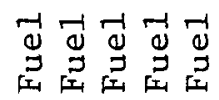

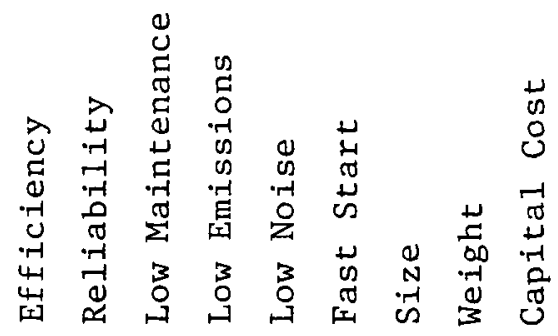


At this point, it was then possible to produce a weighted average rating factor for each application class to serve as a measure of the utility of using PAFC in this application by displacing the conventional system. This was accomplished by taking the rating factors, comparing the PAFC and relevant conventional system from Table 5,1, and multiplying them by the respective weighting factors for a specific application class as displayed in Table 5.2. Examples are shown in Table 5.2. A complete list of the results of such calculations is shown in Table 5.3.

\subsubsection{Application Selection}

Application classes which received the most favorable ratings in the analysis displayed in Table 5.3 are listed in Table 5.4. Seven application classes with overall ratings of 3.2 or greater were selected and a specific application from each such class chosen for further evaluation. In addition, four lower rank classes were selected and an application from each of those classes chosen for further evaluation in order to improve the diversity of the applications considered for further study.

Al1 applications which achieve ratings higher than 3.5 are cases of remote electric power generation. An Arctic village or Third World village power system was chosen to represent large remote electric power generation, and multipurpose oil and gas field power supply was chosen to represent that industry. The small remote electric power class was dropped from consideration because the specific applications which had been identified for inclusion in that class all proved to be too small for consideration in this study (less than $10 \mathrm{~kW}$ ).

Review of applications with ratings between 3.2 and 3.5 also includes several remote power cases. Of these, the class of power for remote mining and agribusiness operation was accepted, with power for a remote ethanol plant chosen as a specific application for consideration. Also selected was small remote mechanical power, with the specific application chosen being that of rural well and irrigation pumps. Rejected were medium to large remote mechanical power and remote power for the entertainment industry. The former was rejected because attractive applications within this class were basically similar to those covered in oil and gas field power. The latter was rejected because the market was considered to be too small.

Other application of classes accepted for further evaluation include: long-lived underground mine equipment, with the mine locomotive being a specific application chosen for further evaluation; coastal and in-land water vessels, with the tow boat being the specific application chosen; and medium to large electric power generation subject to volume restriction, with the railroad locomotive being chosen as the application for further evaluation. Small submersibles and cruise ships were rejected because 


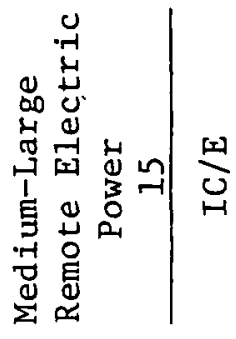

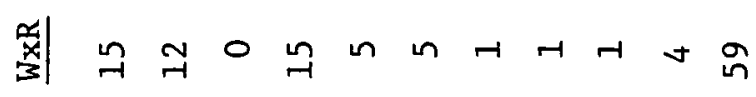

$\underset{g}{g}$

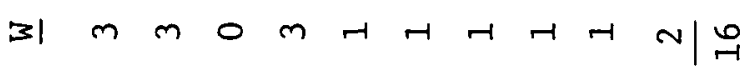

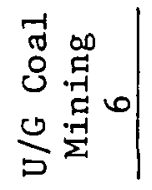

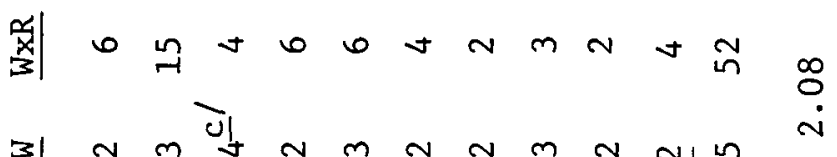

$3 \sim m$ Uु $N M N N M N$

r. 盿

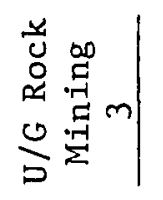

$\underset{\sqcup}{\stackrel{\Xi}{U}}$

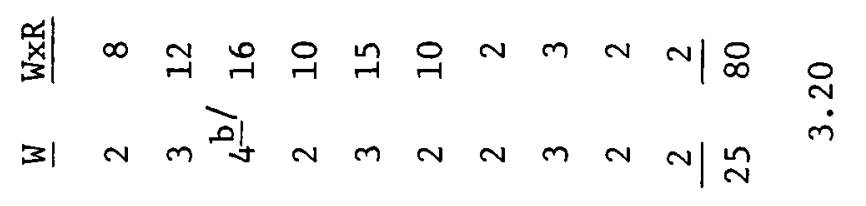




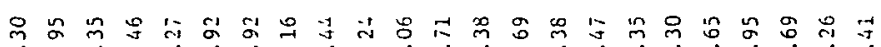

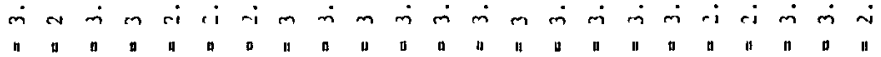

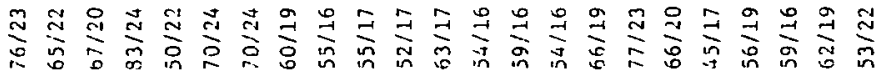

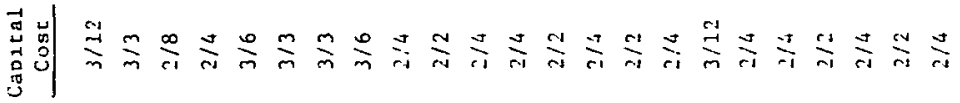

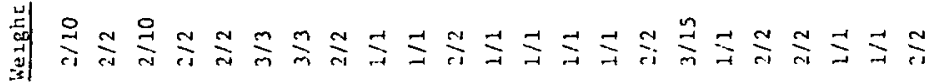

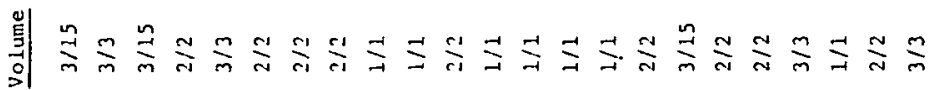

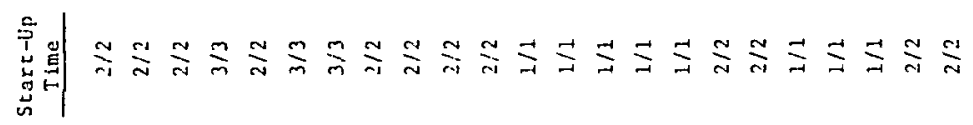

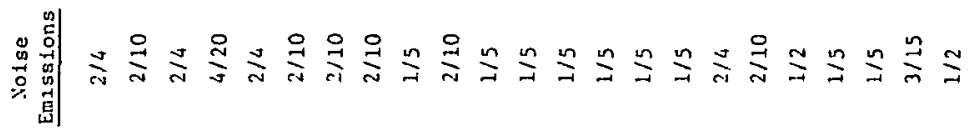

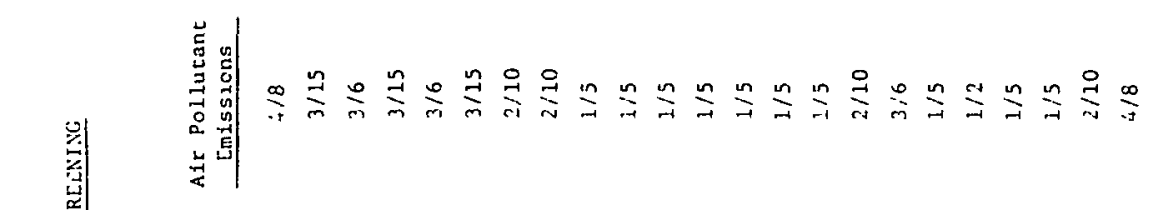

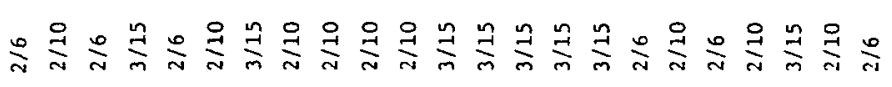

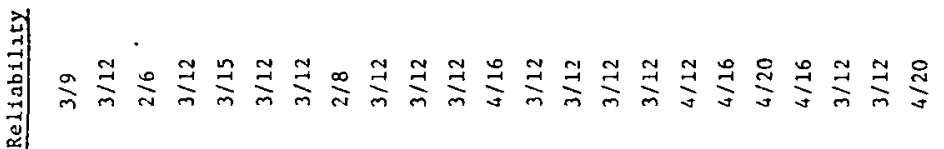

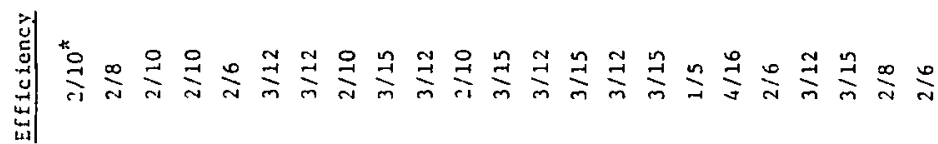

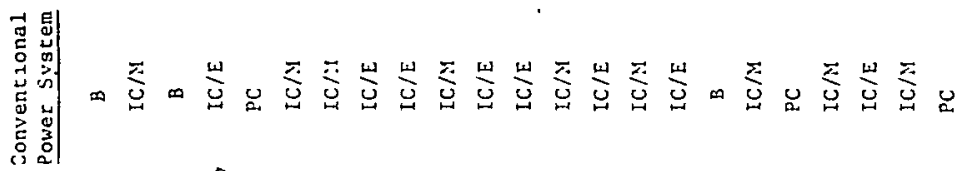

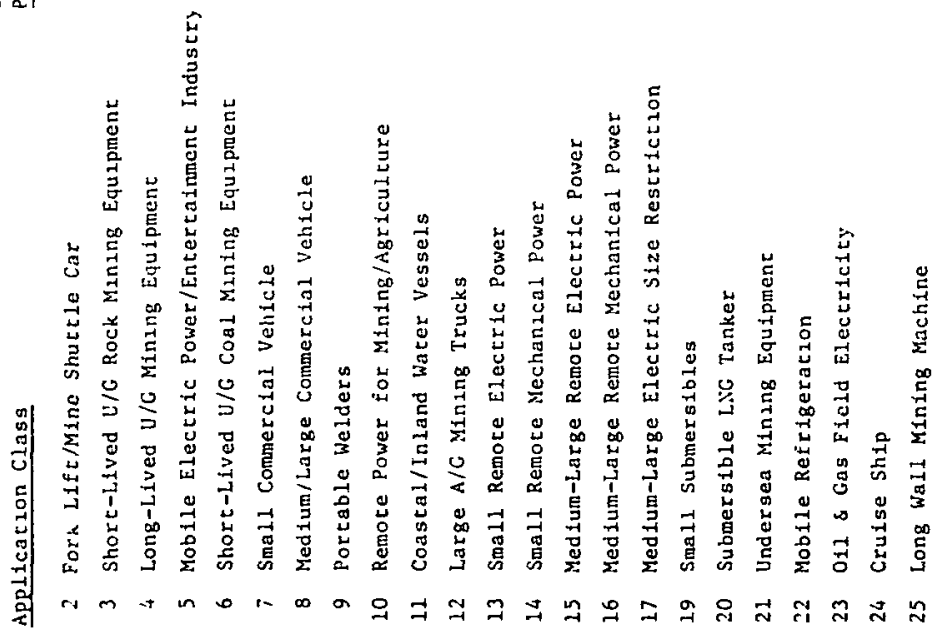


TABLE 5.4

HIGH-RATED APPLICATION CLASSES

Class

No.

Applications Rated over 3.5

13 Smal1 Remote Electric Power No

15 Large " " $"$ Yes

$23 \quad 0 i 1$ and Gas Field Power
Accepted?

Yes/No

Yes
Application to be Studied or

Reason for Rejection

Appropriate Candidates Were Too Sma11

Arctic Village or Third World Power

Oil and Gas Field Power

Applications Rated Between 3.2 and 3.5

2 Forklift Truck, Mine

Shuttle Car

4

5

10

11

11

14

16

17

17

19

20

24

\section{Other Classes/Applications}

7

8
ment Industry

Power for Remote Mining/ Agribusiness

Coastal and Inland Water Vessels

Smal1 Commercial Vehi

8

Medium/Large " "

2 Large A/G Mining Trucks

Long Lived UG Mine Equipment

No

Yes

$$
\text { Similar to Class } 4
$$

Mine Locomotive

Remote Power for Entertain-

No

Market Too Small

Yes

Ethanol Plant Power

Yes

Tow Boat

Yes Rural We11 and Irrigation Pumps

No

Attractive Applications Also Included in Class 23

Yes Railroad Locomotive

No Market Too Small

No Market Too Futuristic

No Market Too Small

Yes

Taxi

Yes

Long Haul Truck

Yes

Large A/G Mining Trucks

Yes

Mobile Refrigeration Units 
their markets were considered to be too small. Submersible tankers were rejected because the market was considered to be too futuristic. Finally, the forklift truck/mine shuttle car class was rejected because it was considered to be similar to but less attractive than the mine locomotive.

This partial list of applications is heavily weighted toward remote power, and essentially devoid of any consumer or light duty commercial vehicular application. To enhance the diversity of the application list, four lower rated classes were chosen for further evaluation. An urban taxi was chosen to represent small commercial vehicles, a long haul truck to represent medium to large commercial vehicles. Large above ground mining trucks and mobile refrigeration units were also chosen for further consideration.

Subsequent discussions with NASA led to minor changes in the list of applications to be evaluated, as shown in Table 5,5. Each of these potential fuel cell systems is discussed in the following sections.

\subsection{THIRD WORLD ETHANOL PLANT POWER}

This application was chosen to incorporate aspects of several possible fuel cell applications:

- An example of PAFC use for large, remote power generation;

- An example of PAFC use for Third World power generation; and

- An example of a PAFC system powered on biomass.

It was expected that such an ethanol plant would be located close to the resource base used for ethanol production, but far from other centers of economic activity. It would therefore have to generate its own Dower.

Existence of such a plant presupposes that this facility would produce ethanol at costs sufficiently below the cost of refined petroleum products that production costs plus costs of transport to a large demand center would not exceed the cost of refined petroleum products.

It was expected that the conventional alternative to the fuel cell

would be a diesel engine modified to use ethanol. With these considerations in mind, a specific plant concept was selected.

This plant concept had to be based on use of a specific resource for production of ethanol. Three possible resources were considered: 
TABLE 5.5

APPLICATIONS FOR TECHNICAL EVALUATION

Ethanol Plant Power

Long Haul Truck

Urban Transit Coach

Taxi

Mobile Refrigerator

Submersible

Arctic Village Power

Mine Locomotive

Forklift Truck

Railroad Locomotive

Towboat 
- Grain;

- Sugar cane; and

- Wood-based cellulose.

Detailed consideration of grain-to-ethanol production technology and economics indicated that PAFC might offer a good thermodynamic fit. However, this technology, which uses edible food grains as a feedstock, has a very questionable economic future without substantial subsidies such as those currently provided in the United States. Furthermore, production from grain can only be expected to be attractive in the temperate zones, where it is likely to be conducted in developed countries with extensive power grids, etc. Thus, if grain-based ethanol production has an unsubsidized future, it is not likely to be in developing Third World countries.

Sugar cane is currently used as the basis for producing large quantities of ethanol fuel in the tropics in developing countries. Under circumstances of high world oil prices, this mode of ethanol production has proved economical. Consideration of the production process, however, reveals that the bagasse residue of sugar cane is more than adequate to provide all process energy, including electric power.

Consideration was next directed to the cellulose-to-ethanol processes now being developed. These processes typically use enzymatic hydrolysis to reduce cellulose to sugars. These sugars are then fermented to produce ethanol. Review of the processes now under development in the United States indicated that most need electricity and some need steam over and above that which can be produced from process wastes and/or waste heat. Based on this information, and the attractive future prospects of cellulose-based ethanol production in rain forest areas of the globe, it was chosen as the basis of the ethanol plant concept to be evaluated for PAFC use. It was expected that economical plant size would lead to a power requirement of approximately $3,000 \mathrm{KW}$.

More detailed consideration of the cellulose-to-ethanol processes led to the conclusion that the conventional system against which it would be appropriate to evaluate PAFC would not be a diesel-electric system. Rather, the most attractive conventional system would be a wood-fired steamrelectric system. This conclusion was reached based upon the finding that the ethanol production process itself is on $1 y$ approximately $26 \%$ efficient based on the higher heating value of wood feed and of ethanol product. Subsequent use of ethanol in a diesel engine generator would yield a compound efficiency which would be much lower than that which could be achieved with use of a simple wood-fired boiler for electric power generation and/or cogeneration of electricity and process steam.

Table 5.6 summarizes the comparison between the conventional steamelectric and prospective PAFC power systems. The efficiency comparison appears to favor PAFC, However, the $46 \%$ efficient, PAFC system is based on use of ethanol, while the conventional systems $22 \%$ 
TABLE 5.6

$3000 \mathrm{KW}$ CELLULOSE BASED ETHANOL PLANT POWER SYSTEM CHARACTERISTICS

Conventional Power System

Steam Electric Power Generation; Wood Fuel

Proposed PAFC Power System

Conventional Steam Reformer, $500 \mathrm{kPa}$ Low Power Density Fuel Cell, DC/AC Inverter; Ethanol Fuel

Operating Hours/Year (Exclusive of Time or Hot Standby): 8,000

Power System/

Characteristic

Conventional

Efficiency, \% 22

46

Weight, $\mathrm{Kg}$ Volume, $\mathrm{M}^{3}$

NA

125
NA

545
Capital

Cost, $\$ 1000$

4500

9400 
efficiency is based on use of wood. The wood-based efficiency of the PAFC system would be equal to $46 \% \times 0.26=12 \%$ efficiency, much lower than that displayed by the conventional steam electric system.

Weight and volume are, of course, unimportant in evaluation of a stationary power system such as this. Capital cost is important and also favors the conventional system. It should be noted that this capital cost for the PAFC system does not make any prorated allowance for the capital investment for the portion of the ethanol plant which would be producing ethanol to feed to the PAFC system. Such an assessment of the total capital cost to convert wood to ethanol to electricity via PAFC would even more strongly favor the conventional system.

Since PAFC.displays substantial disadvantages both in resource utilization efficiency and in capital cost when compared to the steamrelectric system, it is not recommended for further consideration for ethanol plant power.

\subsection{LONG HAUL TRUCK TRACTOR POWER SYSTEM}

The trucking application chosen for PAFC is the long haul truck tractor. It was chosen in order to maximize operating hours per year (with use of a two driver team), maximize operation at high load factors, and thereby maximize savings expected to result from its greater fuel efficiency when compared to its conventional alternative, a high speed diesel engine. Choice of an application which offers a large number of operating hours per year also offers good capital utilization, important in justifying the higher capital cost of PAFC.

Table 5.7 displays the efficiency, weight, volume, and capital cost of a high-speed diesel engine providing $391 \mathrm{~kW}$ of shaft power, as would be required in a large long haul truck tractor. The diesel and fuel cell systems include carrying eight full power hour equivalents of fuel on board. It must be emphasized that these figures come from the Hardware Data Base, and actually describe a very long lived, stationary system. Information found in the literature describing the bare equipment weight, volume, and cost of truck diesel engines will report somewhat lower figures for all parameters, Possible reasons for this discrepancy are given in Chapter 3. In any case, it is expected that the differences between weights, volumes, etc. of diesel and PAFC systems as reported in Table 5.7 accurately reflect the differentials between PAFC and diesel systems designed for truck tractor use.

Two possible fuel cell systens were considered for use in trucl: tractors. They are identical in all respects except that one uses a lower power density fuel cell stack, while the other uses a high power density stack. Both include an electric motor to produce shaft power. Table 5.7 lists the components' efficiency, weight, volume, and cost for each PAFC systein. 
$391 \mathrm{KW}$ LONG HAUL TRUCK TRACTOR POWER SYSTEM CHARACTERISTIC

Conventional Power System

High Speed Diese1 Engine; Diese1 Fuel

Propośed PAFC Power System

(1) Low Temperature Steam Reformer (No $\mathrm{H}_{2} \mathrm{O}$ Recycle), $500 \mathrm{kPa}$ Low Power Density Fuel Cell, DC/DC Converter, DC Motor, Methanol Fuel

(2) Low Temperature Steam Reformer (No $\mathrm{H}_{2} \mathrm{O}$ Recycle), $500 \mathrm{kPa}$ High Power Density Fuel Cel1, DC/DC Converter, DC Motor, Methanol Fuel

Operating Hours/Year (Exclusive of Time or Hot Standby): 2,500

On board fuel storage: 8 Full power-hours equivalent.

Power System/ Characteristic*

Conventional

PAFC (1)

PAFC (2)

$\frac{\text { Efficiency, \% }}{35.0}$

38.8

35.4

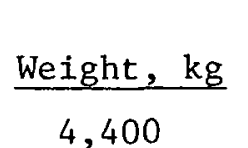

13,500

12,200

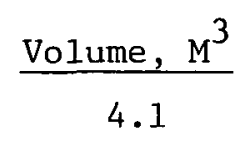

31.4

26.1
Capital Cost, $\$ 1000$ 100

1,420 940

*Characteristics reflect properties of 1ong-lived stationary systems. Absolute values quoted do not describe other types of power systems (especially those for vehicular use) accurately. Arithmetic differences between values quoted for different systems should be valid. 
Meaningful comparison of the efficiencies, weights, and volumes of the candidate power systems requires a consideration of the truck tractor and its duty. In particular, efficiency of shaft power production is not the meaningful measure of truck tractor efficiency; the figure of merit should be Gj of fuel used per T.KM of cargo haulage. Evaluation of this parameter requires simultaneous consideration of power system shaft power efficiency and power system weight. Over the course of its life, the truck tractor will cruise without a trailer, with an empty trailer, and with a trailer carrying payloads varying up to a legal weight limit. When the truck is not fully loaded, a fuel cell power system will add more to the weight of the truck than will the diesel power system, increasing resistance to movement and thereby detracting from system efficiency. At times when the truck operates at its legal weight limit, approximately $35 \mathrm{~T}$, the added weight of the fuel cell displaces cargo weight. As a proxy for comparative efficiency evaluation over the range of possible cargo loads, relative fuel consumption rates per T.KM of useful cargo haulage are computed below for a truck powered by each system considered here, when loaded to the legal limit. These calculations are based on the assumption that operation at engine full load will result in a sustained truck speed of $100 \mathrm{KM} / \mathrm{r}$.

Fuel consumption per T.KM of freight haulage $\left(\mathrm{FC}_{\mathrm{x}}\right)$;

$\mathrm{FC}_{\text {Diese1 }}=\frac{(391 \mathrm{~kW} \text { power })(3.6 \mathrm{Mj} / \mathrm{kWh})}{(100 \mathrm{M} / \mathrm{h})\left(0.35 \frac{\mathrm{Gj} \text { power }}{\mathrm{Gj} \text { fuel }}\right)} \frac{1}{(30.5 \mathrm{~T} \text { payload })}=1.32 \frac{\mathrm{Mj} \text { fuel }}{\mathrm{t} \cdot \mathrm{KM} \text { payload }}$ $\mathrm{FC}_{\text {PAFC 1 }}=\frac{(391 \mathrm{~kW} \text { power })(3.6 \mathrm{Mj} / \mathrm{kWh})}{(100 \mathrm{KM} / \mathrm{h})\left(0.388 \frac{\mathrm{Gj} \text { power }}{\mathrm{Gj} \text { fuel }}\right)} \frac{1}{(21.4 \mathrm{~T} \text { payload })}=1.70 \frac{\mathrm{Mj} \text { fuel }}{\mathrm{t} \cdot \mathrm{KM} \text { payload }}$ $\mathrm{FC}_{\mathrm{PAFC} 2}=\frac{(391 \mathrm{~kW} \text { power })(3.6 \mathrm{Mj} / \mathrm{kWh})}{(100 \mathrm{KM} / \mathrm{h})\left(0.354 \frac{\mathrm{Gj} \text { power }}{\mathrm{Gj} \text { fuel }}\right)} \frac{\mathrm{I}}{(22.9 \mathrm{~T} \text { payload })}=1.74 \frac{\mathrm{Mj} \text { fuel }}{\mathrm{t} \cdot \mathrm{KM} \text { payload }}$

While these fuel expenditures per T.KM of cargo haulage cannot be regarded as strictly accurate in absolute terms, their relative values should be valid. Thus, it can be seen that the heavier fuel cell systems, though producing shaft power more efficiently, will actually result in greater fuel expenditures per T.KM of payload haulage. Consequently, the fuel cell system must be regarded as less efficient than the diesel system. In fact, if strong fuel cost/availability incentives exist to operate trucks on methanol, it is likely that it would be more efficient to use diesel engines modified to burn methanol than to use a fuel cell. 
System volume and capital costs also favor the diesel. The volume differentials, although large, could be expected, however, to pose relatively minor difficulties in truck design compared to those imposed by fuel cell system weight. The capital cost differential might be expected to decline substantially as a result of learning curve effects experienced in mass production for such a high volume application as this. However, it could not be expected to fall below that of the conventional system. This, coupled with the substantially greater rate of fuel consumption per T.KM of payload haulage make fuel cells an unattractive application for long haul trucks and are not recommended for further consideration. However, attractiveness of the PAFC systems would be most strongly enhanced by technological developments which lead to substantial reduction in system weight and capital cost.

\subsection{URBAN TRANSIT COACH}

The urban transit coach was selected for evaluation since it is of vital importance in many urban environments in the United States, It is of particular importance to the U. S. Govermment since purchase and operation of these vehicles frequently are federally subsidized. It was also selected because it might lend itself to very frequent refuelings, thereby allowing the use of hydrogen generated at a transit station.

The conventional power system used in urban transit coaches is a high-speed diesel engine producing shaft power coupled mechanically to the wheels of the bus. No intermediate generation of electricity is required (except for very small auxiliary power requirements). Data on efficiency, weight, volume, and cost for the conventional and fuel cell systems is provided in Table 5.8. As noted previously for the long haul truck case, this data actually describes long-lived stationary systems. The differentials should be valid, however, for mobile power.

Two possible candidate phosphoric acid fuel cell systems were considered for this application. Both would carry essentially pure hydrogen on board the coach stored as a metal hydride. Both would use fuel cell power sections operated at $500 \mathrm{kPa}$, with one designed for low power density and the other for high power density operation. Both systems would require a DC/DC converter and a DC motor.

Hydrogen for the fuel cell systems would be generated at a transit station for recharge onto the coaches. This hydrogen would be generated from methanol, with an estimated $85 \%$ thermal efficiency. This thermal efficiency is based on use of technology consistent with that used in the methanol fuel processors considered for methanol-based fuel cell systems; it differs in requiring product purification, using the waste stream from gas purification to fire the reformer, and in being unable to use power section waste heat. 
TABLE 5.8

$209 \mathrm{KW}$ URBAN TRANSIT COACH POWER SYSTEM CHARACTERISTIC

Conventional Power System

High Speed Diesel Engine; Diesel Fuel

Proposed PAFC Power System

(1) $500 \mathrm{kPa}$ Low Power Density Fuel Ce11, DC/DC Converter, DC Motor, Hydrogen Fuel (Hydride Storage)

(2) $500 \mathrm{kPa}$ High Power Density Fuel Cell, DC/DC Converter, DC Motor, Hydrogen Fuel (Hydride Storage)

Operating Hours/Year (Exclusive of Time or Hot Standby): 3,000 On board fuel storage: 2 Full power hours equivalent.

Power System/ Characteristic*

$\begin{array}{ccccc}\text { Efficiency, } \% & \text { Weight, } \mathrm{kg} & \text { Volume, } \mathrm{M}^{3} & & \begin{array}{c}\text { Capital } \\ \text { Cost, } \$ 1000\end{array} \\ 35.0 & 2,050 & 1.7 & & 53 \\ 40.6 & 5,810 & 4.1 & 750 \\ 37.0 & 4,630 & 7.4 & & 487\end{array}$

*Characteristics reflect properties of long-lived stationary systems. Absolute values quoted do not describe other sorts of power systems (especially those for vehicular use) accurately. Arithmetic differences between values quoted for different systems should be valid. 
The efficiencies quoted are on-board fuel efficiencies, and seem to favor the fuel cell. In order to conduct a meaningful evaluation of fuel cell system efficiency, however, it is necessary to include energy losses in hydrogen production from methanol at the transit station, and the impact on total.coach energy efficiency of the added weight of the fuel cell system. Concerning the former adjustment, it was noted previously that hydrogen generation from methanol is conducted with an efficiency of $85 \%$. Concerning weight, UMTA data indicates that overall coach fuel efficiency declines by $1 \%$ for each $2 \%$ additional weight. A modern coach weighs approximately $12 . \% \mathrm{~T}$; therefore, the $3.7 \mathrm{~T}$ by which the low power density PAFC system exceeds the conventional diesel system weight is equivalent to an addition of approximately $30 \%$ to coach weight. The high power density system would add approximately $20 \%$ to coach weight. This would result in $15 \%$ and $10 \%$ reductions in overall coach efficiency, respectively. The aggregate results of these adjustments are shown below:

\section{Adjustments to Comparative System Efficiencies}

Conventional Diesel Engine Fuel-to-Shaft-Power Efficiency

PAFC $_{1}$ Weight-Adjusted Methano1-to-Shaft-Power Efficiency:

$$
(40.6) \times \quad \begin{gathered}
\mathrm{CH}_{3} \mathrm{OH} \text { to } \mathrm{H}_{2} \quad \begin{array}{c}
\text { Weight } \\
\text { Adjustment } \\
(0.85)
\end{array} \times(0.85) \\
(0.85)
\end{gathered}
$$

PAFC $_{2}$ Weight-Adjusted Methanol-to-Shaft-Power Efficiency:

$$
\begin{gathered}
\mathrm{CH}_{3} \mathrm{OH} \text { to } \mathrm{H}_{2} \quad \begin{array}{c}
\text { Weight } \\
\text { Adjustment }
\end{array} \\
(37.0) \times(0.85) \times(0.90)
\end{gathered}=
$$

These efficiency numbers cannot be regarded as absolute, since neither include adjustment of efficiency for fuel mileage appropriate to the urban transit coach. The conclusion of the comparison is, nevertheless, clear. After adjusting for hydrogen production at the transit station and for the impact on coach fuel consumption of the added weight associated with the fuel cell, the conventional system would enjoy a substantial fuel efficiency advantage.

The weight increment is expected to cause no further problems beyond those included in the calculations involved. The volume differentials are small and are not expected to impact PAFC viability. Capital cost differentials are quite large and would impact PAFC viability adversely, even after substantial learning curve related cost reduction.

The fuel cell does offer one definite advantage compared to the conventional diesel system or urban transit coach application--reduced 
emissions of air pollutants. It seems unlikely, however, that this advantage alone can overcome both a capital cost and a fuel efficiency disadvantage. Furthermore, in applications where cleanliness is of paramount importance, bus route electrification is also an option. With PAFC posing such disadvantages and offering little compensating advantage, this application is not recommended for further consideration.

By far the most important developments in PAFC technology required for viability as a power system for urban transit coaches would be reduction in system weight and in system capital costs. As with the long haul truck, the very substantial additional weight associated with PAFC more than offset any fuel efficiency advantage it might offer. The capital cost of the PAFC system accounted on the prototype basis is roughly ten times that of the conventional system and must be reduced drastically if PAFC are to be given serious consideration as a vehicular power source.

\subsection{URBAN TAXI}

The urban taxi was chosen for evaluation because it is a large identifiable class of use for a small, passenger-carrying vehicle which would experience a very large number of annual operating hours, perhaps as many as 4,000-5,000. It was also selected because it represents a class of fleet vehicle operated in dense urban centers, which in some places has already been subjected to regulation more stringent than that required of the general automobile population for control of air pollutant emissions. Furthermore, like the urban transit coach, it was expected that it would be amenable to design and operation based on frequent refuelings at dedicated facilities, thereby allowing use of hydrogen.

The conventional power system used in urban taxis may be a gasoline engine or a high speed diesel engine. If fuel economy is of concern, which is assumed when the fuel cell is contemplated for use, the engine choice is clearly the diesel. Therefore evaluation of PAFC in comparison to the diesel engine is appropriate for this analysis.

Data on efficiency, weight, volume, and cost of the conventional and candidate fuel cell systems is presented in Table 5.9. Once again, it should be noted that these absolute figures actually describe a long-lived stationary system. They should be considered only in comparison with the PAFC systems and not used for absolute characterization of diesel taxi engines.

Two possible candidate phosphoric acid fuel cell systems were considered for this application. Both carry essentially pure hydrogen on board the taxi, stored as a metal hydride. Both would use fuel cell power sections operated at approximately ambient pressure, with one designed for low power density and the other for high power density operation. Both systems would require a DC/DC converter and a DC motor. 


\section{Conventional Power System}

High Speed Diesel Engine, Diese1 Fuel

\section{Proposed PAFC Power Systems}

(1) Ambient Pressure Low Power Density Fuel Cell, DC/DC Converter, DC Motor, Hydrogen Fuel (Hydride Storage)

(2) Ambient Pressure High Power Density Fuel Ce11, DC/DC Converter, DC Motor, Hydrogen Fuel (Hydride Storage)

Operating Hours/Year (exclusive of time on hot standby): 3,000 On Board Fuel Storage: 2 full power hours equivalent

\begin{tabular}{|c|c|c|c|c|}
\hline Power System/Characteristic** & $\begin{array}{c}\text { Efficiency } \\
(\%)\end{array}$ & $\begin{array}{l}\text { Weight } \\
(\mathrm{kg})\end{array}$ & $\begin{array}{c}\text { Volume } \\
\left(\mathrm{M}^{3}\right)\end{array}$ & $\begin{array}{c}\text { Capital Cost } \\
(\$ 1000)\end{array}$ \\
\hline Conventional & 35.0 & 412 & 1.1 & 38 \\
\hline PAFC 1 & 39.2 & 1570 & 3.3 & 189 \\
\hline PAFC 2 & 35.7 & 1078 & 2.1 & 122 \\
\hline
\end{tabular}

*Characteristics reflect properties of long-lived stationary systems. Absolute values quoted do not describe other sorts of power systems (especially those for vehicular use) accurately. Arithmetic differences between values quoted for different systems should be valid. 
Hydrogen for the fuel cell systems would be generated at a taxi stand for recharge onto the taxis. This hydrogen would be generated from methanol, with an estimated $85 \%$ thermal efficiency, as described for the urban transit coach in Section 5.4 .

Table 5.9 also presents data on efficiency, weight, volume, and cost of the two PAFC systems. The efficiencies quoted are on-board fuel efficiencies and, as with the urban transit coach, seem to favor the fuel cell. Analogous adjustment of these comparative efficiencies to reflect the impact of energy loss in hydrogen generation at the taxi station and impact on vehicle energy efficiency of the added weight contributed by the fuel cell system (a 97\% increase for the low power density PAFC system and a $67 \%$ increase for the high power density system), indicates that appropriate comparative system efficiency numbers would be:

- Conventional, 35\%;

- Low power density PAFC, 23.6\%;

- High power density PAFC, 24.3\%.

As noted previously for the urban transit coach, it must be emphasized that these numbers reflect relative vehicular performance only; these relative values and the resulting conclusions are valid. After adjusting for hydrogen production at the taxi stand and for impact on vehicle fuel consumption of the added weight associated with the fuel cell, the conventional system would enjoy a substantial fuel efficiency advantage.

Unlike the urban transit coach, the weight and volume increments associated with PAFC may also pose technical problems in their own right as attempts are made to accommodate them within an urban taxi. Capital cost differentials are very large, and would likely remain so even after substantial learning curve related cost reduction.

The fuel cell does offer a significant advantage over the diesel system in reducing emissions of air pollutants. It seems unlikely, however, that this advantage alone can overcome both the capital cost and fuel efficiency disadvantages described above. Other somewhat less effective remedies for air pollutant emission problems can be implemented at far lower cost and with much greater energy efficiency. Options include conversion of taxi fleets to use of LPG, as has been done in Alberta. Faced with such PAFC disadvantages, this application is not recommended for further evaluation.

Essentially the same developments in PAFC technology would be required to establish viability of use for urban taxis as for urban transit coaches: substantial reduction in system weight and in system capital costs. Also important, would be developments to reduce system volume. 


\subsection{POWER FOR MOBILE REFRIGERATION}

Refrigerated trucks and railroad cars require an on-board refrigeration system which operates independent of any source of vehicular motive power. Use of a fuel cell was selected for evaluation since such systems operate at relatively high load factors (up to 6,000 hours per year). They were originally perceived to offer an opportunity for the fuel cell's superior efficiency to help offset its capital cost disadvantage. They were also selected because a high premium can be paid in this application for a highly reliable system; a failed refrigeration system may result in lost cargo.

As with the urban taxi, both gasoline engines and diesel engines are conventionally used to power such refrigerator systems. Once again, however, it is considered appropriate to compare the fuel cell with the diesel engine, since for any user concerned with fuel efficiency, this will be the system of choice.

Also like the urban taxi, this power system must produce shaft power for running the refrigerator compressor, in addition to very minor electric power requirements for auxiliaries. Data on efficiency, weight, volume, and cost of this conventional system is provided in Table 5.10. Consistent with the need to operate the system free of attendants for long periods of time, all systems considered would carry an equivalent of 48 full power-hours of fuel on board.

Two possible candidate phosphoric acid fuel cell systems are considered for this application. Both will carry methanol fuel, and use power sections which operate at essentially ambient pressure. One will use a low power density power section while the other will use a high power density power section. Both would require a DC/DC converter and a DC motor.

Table 5.10 also presents data on efficiency, weight, volume, and cost of these two PAFC systems. While it was noted previously that efficiency was expected to be the principal attraction of the fuel cell in this application, only the low power density PAFC system actually offers an efficiency advantage. Analysis of the impact of the greater weight of the fuel cell system on the cargo carrying capability of the long haul truck (analogous to the analysis conducted on PAFC for long haul truck tractor power in Section 5.3) indicates that the PAFC system would actually consume significantly more energy per $\mathrm{T}, \mathrm{KM}$ of cargo haulage than

would the diesel system. Analysis of impact of this added weight produces similar results even in a railroad refrigerator car case. Thus, it can be expected that PAFC offers no net efficiency improvement over conventional. diesel systems.

In the future a technologically mature fuel cell system with its limited number of moving parts might offer more reliable operation than a diesel engine for refrigerator system power. This advantage can be proven to exist only by establishment of a record of high reliability in industrial use. Thus, this advantage is not likely to be perceived as significant in the early years of PAFC use. Since PAFC poses such disadvantages in capital cost and fuel efficiency and will not soon offer offsetting advantages, this application is not recommended for further consideration. 
TABLE 5.10

$10 \mathrm{KW}$ MOBILE REFRIGERATION POWER. SYSTEM CHARACTERISTICS

Conventional Power Systen

High Speed Diesel Engine; Diesel Fuel

Proposed PAFC Power Systems

(1) Low Temperature Steam Reformer $\left(\mathrm{H}_{2} \mathrm{O}\right.$ Recycle), Ambient Pressure Low Power Density Fuel Ce11, DC/DC Converter, DC Motor Methanol Fuel

(2) Low Temperature Steam Reformer ( $\mathrm{H}_{2} \mathrm{O}$ Recycle), Ambient Pressure High Power Density Fuel Ce11, DC/DC Converter, DC Motor, Methanol Fuel

Operating Hours/Year (exclusive of time on hot standby): 6,000

On Board Fuel Storage: 48 Full Power Hours Equivalent

$\begin{array}{lccccc}\text { Power System/Characteristic* } & \begin{array}{c}\text { Efficiency } \\ (\%)\end{array} & \begin{array}{c}\text { Weight } \\ (\mathrm{kg})\end{array} & \begin{array}{c}\text { Volume } \\ \left(\mathrm{M}^{3}\right)\end{array} & \begin{array}{c}\text { Capital Cost } \\ (\$ 1000)\end{array} \\ \text { Conventional } & 35.0 & & 239 & 0.5 & 4.5 \\ \text { PAFC 1 } & 35.9 & 956 & 1.7 & 61.3 \\ \text { PAFC 2 } & 32.7 & & 860 & 1.5 & 44.3\end{array}$

*Characteristics reflect properties of long-lived stationary systems. Absolute values quoted do not describe other sorts of power systems (especially those for vehicular use) accurately. Arithmetic differences between values quoted for different systems should be valid. 
The most important developments in PAFC technology for establishing tts viability for use powering mobile refrigerator systems would be reduction in system weight, reduction in system capital cost, and demonm stration of high system reliability. As with other mobile systems considered previously, the greater weight of the PAFC system more than offsets any efficiency advantage which they might offer in development of shaft power. On a prototype basis (as quoted in Table 5.10), the capital cost disadvantage of the fuel cell is quite large; this also would have to be reduced substantially as a result of technological improvements and/or learning curve cost reduction facts. Finally, reliability at or exceeding the level demonstrated by diesel systems must be demonstrated thorough1y by the candidate PAFC system.

\subsection{ARCTIC VILLAGE POWER SYSTEM}

Arctic village power systems were chosen as a possible application for phosphoric acid fuel cells because they constitute an application in which fuel efficiency is of very high value. Delivered fuel costs in these villages typically are twice the costs prevailing in most of the contiguous lower 48 states. Furthermore, the purchase, operation, maintenance, and fueling of such power systems are typically subsidized by national or state/provincial governments, which are concerned with minimizing overall power costs and which have access to inexpensive capital for financing these capital intensive systems.

The conventional power system used in arctic village power systems is the high-speed diesel engine with generator. A typical village will have three to four such generators, with a total capacity which significantly exceeds twice the peak electric demand of the village. Data on efficiency, weight, volume, and cost of the conventional system is provided in Table 5.11. Of course, weight and volume are inconsequential in this stationary application; they are reported for consistency of presentation only. Fuel storage requirements are not considered; their only input will be on capital costs, and that will be very slight.

Four possible candidate phosphoric acid fuel cell systems were considered for this application. Two would use methano1 as fuel, while two others would use diesel fuel. All four would use power sections which operate at $500 \mathrm{kPa}$. One PAFC system based on each fuel would use a power section designed for high power density operation, and one for low power density operation. All four would use a DC/AC inverter to process their electric power output. A PAFC system introduced into an arctic village power system could be expected to operate for up to 8,000 hours per year since it would be used in preference to the diesel systems whenever it was operable.

Table 5.11 also presents data on efficiency, weight, volume, and cost of the four PAFC systems. A11 four offer efficiency advantages over the conventional system; all four are projected (on a prototype basis) to have much higher capital costs than the diesel system. As is to be expected, the low power density systems offer greater efficiency advantages over the diesel system than do the high power density systems; they also suffer from larger capital cost disadvantages compared to the conventional system. 


\section{Conventional Power System}

High Speed Diesel Engine with Generator; Diesel Fuel

Proposed PAFC Power Systems

(1) Low Temperature Use Steam Reformer $\left(\mathrm{H}_{2} \mathrm{O}\right.$ Recycle), $500 \mathrm{kPa}$ Low Power Density Fuel Cell, DC/AC Inverter; Methanol Fuel

(2) Low Temperature Use Steam Reformer $\left(\mathrm{H}_{2} \mathrm{O}\right.$ Recycle), $500 \mathrm{kPa}$ High Power Density Fuel Cell, DC/AC Inverter; Methanol Fuel

(3) Two Stage Reformer $\left(\mathrm{H}_{2} \mathrm{O}\right.$ Recycle) $500 \mathrm{kPa}$ Low Power Density Fue1 Ce11, DC/AC Inverter; Diese1 Fuel

(4) Two Stage Reformer $\left(\mathrm{H}_{2} \mathrm{O}\right.$ Recycle) $500 \mathrm{kPa}$ High Power Density Fuel Ce11, DC/AC Inverter; Diesel Fuel

Operating Hours/Year (Exclusive of Time or Hot Standby): On board fuel storage: Not Applicable.

Power System/ Characteristic Conventional

PAFC (1)

PAFC (2)

PAFC (3)

PAFC (4)

\begin{tabular}{cr} 
Efficiency, \% & Weight, \\
\hline 33.0 & 1580 \\
40.3 & 3860 \\
36.6 & 3440 \\
37.4 & 7670 \\
34.1 & 7550
\end{tabular}

34.1

7550
Capital

Cost, $\$ 1000$

47

396

274

463

346 
The methanol based systems offer generally higher thermal efficiency and lower capital costs than the diesel fuel-based systems. The diesel fuel based systems are not rejected from the analysis at this point, however, despite this apparent disadvantage, because consideration of possible future fuel cost scenarios must include analysis of cases in which the cost of diesel fuel delivered to a village will be less per gigajoule than the delivered cost of methanol; such circumstances would offer a substantial economic advantage to any system using diesel fuel in comparison to any system using methanol fuel.

No considerations can be made in the Arctic village power system case analogous to those made in Sections 5.2-5.6 which would render PAFC's efficiency advantage insignificant. The Arctic village power systems being considered here are too small for steam electric power generation (possible in the ethanol plant considered in Section 5.2), and no other PAFC system characteristic (such as system weight as was important in vehicular applications) reduces the real PAFC system efficiency for purposes of comparison with diesel system efficiency. Thus, it must be concluded that PAFC does offer a real and important advantage over the conventional system in this case; and that this application should be given further consideration.

The key requirement for establishing commercial viability of PAFC in an Arctic village application will be reduction in capital costs from the prototype levels projected in Table 5.11. Other relatively minor technical developments would have to be pursued to establish PAFC operability in an Arctic environment. These would include operation using coolants with suitably low freezing points and development of a fuel processor which could withstand periodic exposure to Arctic temperatures at times of system failure. The latter is of particular concern since the fuel processor considered here must condense water from the cathode exhaust for recycle for use in steam reforming of the fuel; a fuel processor must, therefore, be designed which will minimize the presence of pure liquid water in the system and/or make parts of the system which contain pure liquid water tolerant of freezing.

\subsection{RAILROAD LOCOMOTIVE}

The railroad locomotive was chosen for evaluation because of its critical importance in the transport of freight in the United States. It is an example of a heavy-duty vehicular application which is expected to be less sensitive to system weight than the vehicular application evaluated above. It is a vehicular application in which all competing power systems must generate electricity to power traction motors; no competing system incorporates a direct mechanical drive.

In defining the railroad locomotive application, it is important to distinguish between two classes of locomotive duty and identify the 
class to be considered. Locomotives can be divided into:

- Road locomotives, used to pull loads long distances, such as between major cities, from coal fields to power plants, etc.;

- Yard locomotives, used to switch cars in the railroad yard and to pick up and deliver small numbers of cars within short distances from the yard.

Road locomotives are larger and are operated more hours per year at generally higher load factors, hence they will be the focus of application analysis.

The conventional power system used in railroad locomotives is a medium speed diesel engine with generator. Data on efficiency, weight, volume, and cost of this conventional system is provided in Table 5.12. All power system descriptions include allowance for carriage of 60 full power hour equivalents of fuel on board. Again, these figures reflect weight, volume, and cost of long-lived, stationary systems, and should not be considered to reflect the absolute values appropriate to the locomotive. The differentials between these figures and the analogous figures estimated for PAFC systems should be valid, however.

Two possible candidate phosphoric acid fuel cell systems were considered for this application. Both would use methanol fuel. Both would use fuel cell power sections operated at $500 \mathrm{kPa}$, with one designed for low power density and the other for high power density operation. Both systems would require a DC/DC converter. A road locomotive could be expected to operate (exclusive of hot stand-by) for 3000-5000 hours per year.

Table 5.12 also presents data on efficiency, weight, volume, and cost of the two PAFC systems. Both of these large, high pressure PAFC systems offer substantial fuel efficiency advantages over the conventional diesel engine generators. They also account for significantly greater weight and volume. The weight differential, however, is expected to be tolerable in a locomotive system; since many diesel locomotives carry ballast weighing as much as this differential. Weight increases up to this level are thus expected to have no impact on locomotive operating efficiency, with increases in rolling resistance being offset by improved traction. This need for substantial operating weight is typical of traction vehicles pulling loads which substantially exceed their own weight. It contrasts importantly with the adverse impact of added weight on the lighter duty vehicles characterized previously.

The added volume attributable to the fuel cell system, approximately 85 cubic meters, may cause difficulties in accommodating the fuel cell within a conventional locomotive envelope. It is expected, however, 
$2237 \mathrm{KW}$ RAILROAD LOCOMOTIVE POWER SYSTEM CHARACTERISTIC

\section{Conventional Power System}

Medium Speed Diesel Engine with Generator; Diesel Fuel

Proposed PAFC Power Systems

(1) Low Temperature Steam Reformer $\left(\mathrm{H}_{2} \mathrm{O}\right.$ Reformer),

$500 \mathrm{kPa}$ Low Power Density Fuel Ce11, DC/DC Converter, Methanol Fuel

(2) Low Temperature Steam Reformer $\left(\mathrm{H}_{2} \mathrm{O}\right.$ Reformer),

$500 \mathrm{kPa}$ High Power Density Fuel Cell, DC/DC Converter, Methanol Fue1

Operating Hours/Year (Exclusive of Time or Hot Standby): 3500-5500

On board fuel storage: $60 \mathrm{Full}$ power hours equivalent.

Power System/ Characteristic*

Conventional

PAFC (1)

PAFC (2)

\section{Efficiency, \%}

33.0

46.9

42.7

Weight, kg
70,000
94,500
93,100

93,100
Volume, $\mathrm{M}^{3}$ 167

250

252
Capital Cost, $\$ 1000$

1480

6640

4270

* Characteristics reflect properties of long lived stationary systems. Absolute values quoted do not describe other sorts of power systems (especially those for vehicular use) accurately. Arithmetic differences between values quoted for different systems should be valid. 
that this accommodation can be made with minor design adaptation, and is not expected to be a major constraint on PAFC use in locomotives.

The conventional system does enjoy a significant capital cost advantage over the prototype PAFC systems. The critical issue in establishing viability of PAFC in the railroad application would be reduction in PAFC system capital costs to such a level that the fuel savings afforded by the higher efficiency of PAFC will justify the remaining capital cost differential between $P A F C$ and conventional sys tems.

Thus, the fuel cell does appear to offer one important technical advantage compared to the conventional system: substantial fuel cost savings. It does so in an application which enjoys a large number of operating hours per year, in which this efficiency advantage will translate into large total fuel savings per year. The fuel cell appears to pose no mitigating technical disadvantages although on a prototype basis it is significantly more expensive than the conventional system. Thus, it appears to be worthy of further consideration.

Three technical/economic developments are necessary to establish PAFC as a viable locomotive power system. Capital cost reduction and volume reduction were mentioned previously. The third is development of a system which is capable of operating essentially in a hot standby condition with negligible fuel consumption and negligible aging of the cell stack for up to 2000 hours per year, during periods analogous to those in which a diesel locomotive throttle is set at idle.

\subsection{TOWBOAT}

The towboat was chosen for evaluation because it is an example of a heavy-duty, mobile system which is expected to be insensitive to power system weight and volume. Operating at high load factors for as much as 6000 hours per year, it is expected to draw substantial economic benefit from improvements in power system efficiency.

The conventional power system used in towboats is a medium-speed diesel engine. Data on efficiency, weight, volume, and cost of this conventional system is provided in Table 5.13. Al1. towboat power systems include allowance for storage of $100 \mathrm{full}$ power hour equivalents of fuel on board. Again, these figures reflect weight, volume, and cost of long-lived, stationary systems, and should not be considered to reflect the absolute values appropriate to the towboat. The differentials between these figures and the analogous figures estimated for PAFC systems should be valid, however. Note that, unlike the locomotive, the towboat can use a diesel engine which develops shaft power, mechanically coupled to the boat's propellers. No large generator is required. 


\section{$4176 \mathrm{~kW}$ TOW BOAT POWER SYSTEM CHARACTERISTIC}

Conventional Power System

Medium Speed Diesel Engine; Diesel Fuel

Proposed PAFC Power Systems

(1) Low Temperature Steam Reformer $\left(\mathrm{H}_{2} \mathrm{O}\right.$ Recycle), $500 \mathrm{kPa}$ Low Power Density Fuel Cel1, DC/DC Converter, DC Motor, Methanol Fuel

(2) Low Temperature Steam Reformer ( $\mathrm{H}_{2} \mathrm{O}$ Recycle), $500 \mathrm{kPa}$ High Power Density Fue1 Ce11, DC/DC Converter, DC Motor, Methanol Fuel

Operating Hours/Year (Exclusive of Time or Hot Standby): On board fuel storage: $100 \mathrm{Full}$ power hours equivalent.

\begin{tabular}{|c|c|c|c|c|}
\hline $\begin{array}{l}\text { Power System/ } \\
\text { Characteristic* }\end{array}$ & Efficiency, \% & Weight, kg & Volume, $\mathrm{M}^{3}$ & $\begin{array}{c}\text { Capital } \\
\text { Cost, } \$ 1000 \\
\end{array}$ \\
\hline Conventional & 35.0 & 147,000 & 304 & 1920 \\
\hline PAFC (1) & 43.1 & 257,000 & 628 & 13500 \\
\hline PAFC (2) & 39.3 & 260,000 & 644 & 8670 \\
\hline
\end{tabular}

* Characteristics reflect properties of long-lived stationary systems. Absolute values quoted do not describe other sorts of power systems (especially those for vehicular use) accurately. Arithmetic differences between values quoted for different systems should be valid. 
Two possible candidate phosphoric acid fuel cell systems were considered for this application. Both would use methanol fuel. Both would use fuel cell power sections operated at $500 \mathrm{kPa}$, with one designed for low power density and the other for high power density operation. Both systems would require a DC/DC converter and a DC motor.

Table 5.13 also presents data on efficiency, weight, volume, and cost of these two PAFC systems. Both offer significant efficiency advantages over the diesel system; efficiency advantages are smaller than those offered in the locomotive case, since there the competition was between electricity-producing systems while in the towboat the comparison is between alternate means of producing shaft power.

Both PAFC systems, including on board fuel storage, will weigh approximately $90 \mathrm{~T}$ more than the conventional system, This differential, although large, is believed to be allowable with proper towboat design. Similarly, the volume differential is not expected to cause significant problems.

The conventional system enjoys a significant capital cost advantage over the prototype PAFC systems. The critical issue in establishing viability of PAFC for use in towboats would be reduction of PAFC capital costs to such a level that the fuel cost savings resulting from the higher efficiency of PAFC will justify the remaining capital cost differential between the conventional PAFC systems. This is the one fuel cell hardware development which will be required to establish its viability in this application.

Thus, the fuel cell appears to offer an important technical advantage compared to the conventional system: higher fuel efficiency. It does so in an application which enjoys a large number of operating hours per year, which will allow this efficiency advantage to translate into large total fuel savings per year. Like the railroad locomotive, there are no mitigating technical disadvantages analogous to those which neutralized PAFC's apparent efficiency edge in trucks, transit coaches, taxis, and mobile refrigerators. Therefore, the fuel cell appears to be worthy of further consideration for use in towboats.

\subsection{MINE LOCOMOTIVE}

A wide variety of machinery is used in underground mines and tunneling operations. In coal mines, practically all equipment is either powered by batteries or power cables. In hardrock mines and tunneling operations, the machinery can be diesel powered. The fuel ce11 clearly offers an advantage over each of these systems:

- Reduced weight, volume, and possible capital cost vis-a-vis batteries;

- Increased flexibility of operation vis-a-vis power cables; 
- Reduction of emissions of pollutants, therefore reduction in ventilation requirements vis-a-vis, diesel engines.

The mine locomotive, a common piece of mining equipment, was chosen for analysis here based on the belief that it would be the piece of equipment most amenable to use of the fuel cell because:

- The mining industry, by purchasing mostly battery and trolley wire powered locomotives, has in effect concluded that the diesel is not an acceptable power system for this application in many operations, thus, the fuel cell can be compared directly to other very clean systems, and estimates need not be developed of the dollar value of the relative cleanliness of the fuel cell, vis-a-vis the diesel.

- The mine locomotive enjoys a relatively long lifetime compared to other underground vehicles; it has a much better chance of achieving an operating lifetime equal to the useful life of a fuel cell stack than does most other underground mining equipment, in particular those vehicles used for working at the ore face.

- The mine locomotive also enjoys relatively high, leve1 load patterns compared to ore face working vehicles, such as the load haul dump, which exhibits short peaks of power demand connected with scooping and lifting rock.

The most common conventional power system in mine locomotives is a rechargeable lead acid battery. Data on weight, volume, efficiency, and cost for this conventional system is provided in Table 5.14. Note that a battery system would actually consist of three battery packs, each with energy storage capability equal to one-half of the expected daily requirement of ten full power operating hours equivalents (including some safety margin). One battery pack would be in operation while the second was recharged and the third was held fully charged on standby. Again, it should be noted that these figures reflect weight, volume, and cost of long-lived, stationary systems, and should not be considered to reflect absolute values appropriate to batteries or fuel cells for vehicular use. The differential between these figures should be valid, however.

Two potential condidate phosphoric acid fuel cell systems are considered for this application. Both would use methanol fuel. Both would use fuel cell power sections operated at $500 \mathrm{kPa}$, with one designed for low power density and the other for high power density operation. Since this system substitutes directly for a battery, it is necessary to consider only the portion of the total power system used to generate unregulated DC. The fuel cell systems are designed to carry ten full power hour equivalents of fuel on board, or enough for heavy operation during a 16 hour work day. A mine locomotive may 
Conventional Power System

Lead Acid Battery

Proposed PAFC Power Systems

(1) Low Temperature Steam Reformer $\left(\mathrm{H}_{2} \mathrm{O}\right.$ Recycle),

$500 \mathrm{kPa}$ Low Power Density Fuel Cell, Methanol Fuel

(2) Low Temperature Steam Reformer $\left(\mathrm{H}_{2} \mathrm{O}\right.$ Recycle),

$500 \mathrm{kPa}$ High Power Density Fuel Cell, Methanol Fuel

Operating Hours/Year (Exclusive of Time or Hot Standby):

On board fuel storage: 10 Full Power Hours equivalent.

Power System/

Characteristic*

\begin{tabular}{crccc} 
Efficiency, \% & Weight, kg & Volume, $\mathrm{M}^{3}$ & & $\begin{array}{c}\text { Capital } \\
\text { Cost, } \$ 1000\end{array}$ \\
\cline { 5 - 5 } 100 & 12470 & 5.3 & 297 \\
42.0 & 1600 & 8.5 & 351 \\
38.3 & 3230 & 7.8 & 234
\end{tabular}

*Characteristics reflect properties of long-lived stationary systems. Absolute values quoted do not describe other sorts of power systems (especially those for vehicular use) accurately. Arithmetic differences between values quoted for different systems should be valid.

**Battery weight and volume are estimated for a single 5-hour battery pack. Cost is for three 5-hour battery packs (one operating, one recharging, one spare). 
experience up to 5,000 hours of operation per year, although their use in some important classes of underground activity (such as underground coal mining) result in their being used far less than this.

Table 5.14 also presents data on efficiency, weight, volume, and cost of the two PAFC systems. This comparison of fuel cell versus battery contrasts markedly with the system comparisons relevant in other cases described above. Efficiency, accounted here at the point of end use, is $100 \%$ for the battery since the battery capacity is defined in terms of the capability to deliver 500 KWh of electricity. It should be noted that this includes no allowance for energy lost in charging of the battery, or in generation of electricty from other fuels at the mine or at some nearby power plant. By contrast, the fuel cell efficiencies are based on production of unregulated DC from methanol. Meaningful comparison of the systems based on efficiency can be made only in terms of implications for total energy costs and/or efficiency accounted in terms of primary energy resources used (natural gas, coal, etc.).

The fuel cell system actually weighs significantly less than the battery system. It is not likely that this will offer much advantage, however, since battery system weight is not a constraint in locomotive design: as a traction vehicle, the locomotive needs essentially all of this weight. The fuel cell system does require somewhat greater volume than does the battery system. It is expected that this would not cause major problems, however, if engineering effort were applied to limit PAFC system volume.

Comparison of PAFC systam prototype costs with battery system costs would seem to indicate that the high power density PAFC would actually be less expensive than the conventional battery system with its three battery packs. It would also indicate that the low power density system is only slightly more expensive. It should be noted, however, that such a large battery system would be required only in those applications where locomotives are used for the greatest number of hours per year, with the highest load factors during use. Nevertheless, the near-capital-costparity displayed here does suggest an important conclusion: fuel cells may offer a very attractive substitute for batteries in situations where heavy loading patterns would require very large amounts of battery energy storage. On this basis, it merits further investigation.

Three principal classes of development would be required to make PAFC technically viable in this application. The first, as previously mentioned, would be modest volume reduction. The second would be capability to maintain a state of hot standby for thousands of hours over life, with minimal fuel consumption and without aging the cell stack. The third would concern minor adaptations to operate in the dust laden environment of an underground mine or tunneling operation. In contrast to applications in which the fuel cell must compete with a diesel, however, it would appear that capital cost reduction from prototype levels is of lesser importance. 


\subsection{FORKLIFT TRUCK}

The forklift truck was chosen for evaluation because it is a common application of a rechargeable battery system to power a vehicle. Such batteries are often used in enclosed environments where air pollutant emissions from internal combustion engines may be unacceptable. In applications where the forklift truck will be operated many hours per day at high load factors, PAFC might be expected to offer the same advantages as displayed in the mine locomotive.

The conventional power system is a rechargeable lead acid battery. As with the mine locomotive, the lead acid battery system would actually consist of three battery packs; one in operation, one recharging, one on standiby, each storing five full power equivalents of electricity. Data on efficiency, weight, volume, and cost of the conventional and fuel cell systems is provided in Table 5.15. Again, these figures reflect weight, volume, and cost of long-lived stationary systems and should not be considered to reflect the absolute yalues appropriate to the locomotive. The differential between conventional and PAFC systems should be valid, however.

Two possible candidate phosphoric acid fuel cell systems are considered for this application. Both would use methanol fuel. Due to the small scale of the PAFC system required here, it is considered impractical to operate at elevated pressures. Therefore, both systems would use ambient pressure power sections, with one designed for low power density and the other for high power density operation. As with the mine locomotive, only the fuel processor and power: sections are required to replace the lead acid battery. Both fuel cell systems include allowance for carriage of ten full power hour equivalents of fuel. Forklift truck use patterns vary widely through industry, with most using 1000 hours per year or less but with very limited applications calling for use of up to 5,000 hours per year.

Table 5.15 also presents data on efficiency, weight, volume, and cost of the two PAFC systems. As noted for the mine vehicle, the end use efficiencies presented here are not comparable, and must be used as a starting point for comparing systems based either on total energy cost or on efficiency of use of primary resources such as coal and natural gas.

The fuel cell offers a weight advantage over the battery system; this is probably not significant, since substantial weight is required on the foklift truck to facilitate its operation. Any weight savings might be made up in ballast.

The slight volume disadvantage attributable to the fuel cell is not expected to preclude its use. It could probably be overcome with application of engineering effort to PAFC volume selection. 


\section{Conventional Power System}

Lead Acid Battery

Proposed PAFC Power Systems

(1) Low Temperature Steam Reformer ( $\mathrm{H}_{2} \mathrm{O}$ Recycle), Ambient Pressure Low Power Density Fuel Ce11, Methano1 Fue1

(2) Low Temperature Steam Reformer $\left(\mathrm{H}_{2} \mathrm{O}\right.$ Recycle), Ambient Pressure High Power Density Fuel Ce1l, Methanol Fuel

Operating Hours/Year (Exclusive of Time or Hot Standby):

On board fuel storage: 10 Full Power-Hours Equivalent.

Power System/ Characteristic*

\begin{tabular}{|c|c|c|c|}
\hline Efficiency, \% & Weight, kg & Volume, $\mathrm{M}^{3}$ & $\begin{array}{c}\text { Capital } \\
\text { Cost, } \$ 1000 \\
\end{array}$ \\
\hline 100 & 1750 & 0.7 & 34 \\
\hline 42.0 & 585 & 1.09 & 46 \\
\hline 38.2 & 501 & 0.89 & 32 \\
\hline
\end{tabular}

*Characteristics reflect properties of long-1ived stationary systems. Absolute values quoted to not describe other sorts of power systems (especially those for vehicular use) accurately. Arithmetic differences between values quoted for different systems should be valid.

**Battery weight and volume are estimated for a single 5-hour battery pack. Cost is for three 5-hour battery packs (one operating, one recharging, one spare). 
The capital cost comparison indicates that the high power density PAFC system may be competitive even at prototype costs in applications which would require the forklift truck to perform duty equivalent to ten full power hours of operation per day. Such applications are rare. Nevertheless, it is encouraging to identify applications in which PAFC capital cost are competitive at PAFC prototype cost levels. On this basis, it is considered to be worthy of further examination.

The forklift truck offers an application in which PAFC might be used with minimal additional technical development. Only modest volume reduction appears to be required. Capital cost reduction would, of course, be desirable, but is much less important than in systems where PAFC must compete with diesel engines.

\subsection{ROBOTIC SUBMERSIBLE}

The robotic submersible was chosen for evaluation because it was expected to offer an opportunity for the fuel cell to compete directly with a battery system to provide steady power levels throughout extended missions. Offering a far superior capability to perform such a job, it could serve to make robotic submersible operation feasible for mission lengths which otherwise might not be possible. Thereby it could greatly broaden the applicability of the robotic submersible.

The robotic submersible is a developing system not in commercial use at this timc. Based on power systems used in current generation manned free-swimming submersibles, it is expected that the conventional power system would be a lead acid battery. Data on efficiency, weight, volume, and cost of this conventional system is provided in Table 5.16. Designed for a 48-hour mission length and capability to change battery packs, the battery system consists of two battery packs each of which will store 40 full power-hour equivalents of energy. Again, these figures reflect weight, volume, and cost of long lived, stationary systems and should not be considered to reflect the absolute values appropriate to the submersible. The differentials between these figures and the analogous figures estimated for PAFC systems should be valid, however.

Two possible candidate phosphoric acid fuel cell systems are considered for this application. Both would use hydrogen as fuel, carried on board stored as a hydride. Both would use fuel cell power sections operated at $500 \mathrm{kPa}$, with one designed for low power density and the other for high power density operation. Both would use compressed oxygen carried on board for the oxidant. Since the PAFC system displaces a battery, only fuel storage and the power section need be evaluated in comparison to the battery. All submersible systems would carry 48 full power-hour equivalents of energy on board. Operating hours per year might range up to 4800 ; this figure is highly speculative, however, since no such system is in commercial operation today. 
$20 \mathrm{KW}$ ROBOT SUBMERSIBLE POWER SYSTEM CHARACTERISTIC

\section{Conventiona1 Power System}

Lead Acid Battery

Proposed PAFC Power Systems

(1) $500 \mathrm{kPa}$ Low Power Density Fuel Cell, Hydrogen Fuel from Hydride Storage, Oxygen from Compressed Storage

(2) $500 \mathrm{kPa}$ High Power Density Fuel Cell, Hydrogen Fuel from Hydride Storage, Oxygen from Compressed Storage

Operating Hours/Year (Exclusive of Time or Hot Standby): 400-4000

On board fuel storage: 48 Full Power-Hours Equivalent.

Power System/

Characteristic ${ }^{*}+$

Conventiona1

PAFC (1)

PAFC (2)

\section{Efficiency, \%}

100

- 61

56

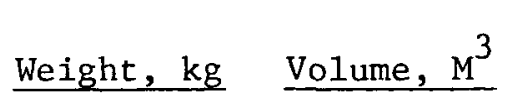

10.1

0.7

0.6
Capital

Cost, $\$ 1000$

357

216

200

*Characteristics reflect properties of long-1ived stationary systems. Absolute values quoted to not describe other sorts of power systems (especially those for vehicular use) accurately. Arithmetic differences between values quoted for different systems should be valid.

tEstimates of efficiency, weight, and volume are for components on the submersible. Cost estimates include the following equipment on board the mother ship: complete diesel generator, recharging system and spare battery pack in the conventional case; Hydrogen generator and shipboard Hydrogen and Oxygen storage for the PAFC. 
Table 5.16 also presents data on efficiency, weight, volume, and cost of the two PAFC systems. As with fuel cell/battery cumparisons discussed above, efficiencies are not directly comparable as stated here. It is noteworthy, however, that the fuel cell enjoys an advantage in all other categories listed, including prototype basis capital costs. Of these, the weight advantage may be of particular importance, since submersible operation is dependent upon capability to lift the submersible out of the water onto the mother ship for periodic servicing. This capability is a key factor in determining the rental rate on a mother ship. Given all the advantages offered by PAFC, this application clearly merits further analysis.

Significant incremental development work remains to be done. A sma11 hydrogen/oxygennfueled PAPC power section is required designed for operation at elevated pressure. Such a system would need to condense its water exhaust for discharge to the environment as 1iquid and use cell stack waste heat to release hydrogen from hydride storage. No fundamental research would be required to establish the technical viability of PAFC in this application, however. 


\subsection{ECONOMIC EVALUATION}

\subsection{SELECTION OF APPLICATIONS FOR ECONOMIC EVALUATION}

Review of the case-by-case analysis reported in Chapter 5 for the first five applications considered indicates that PAFC appear to offer no significant advantages, while suffering substantial disadvantages vis-a-vis the conventional systems. These applications are:

- Cellulose to ethanol plant power systems;

- Long haul truck;

- Urban transit coach;

- Urban taxi;

- Mobile refrigeration.

For ethanol plant power, it was determined that the most resource efficient (and almost certainly the most economical) means of generating the needed power was via steam-electric power generation based on a wood-fired boiler. In the other four systems, it was determined that substitution of a PAFC system for the conventionally used diesel engine would add so much weight that the effect on overall vehicle fuel efficiency would more than offset PAFC's efficiency advantage in providing shaft power; effectively making the diesel systems more efficient than the PAFC systems.

PAFC does appear to offer significant advantages worthy of further investigation in six applications:

- Arctic village power;

- Railroad locomotives;

- Towboats;

- Mine locomotives;

- Forklift trucks;

- Robotic submersibles.

Re-examination of these applications indicates that two, Arctic village power and robotic submersible power, are wholly unique and should be given separate consideration. The other four can be paired based on close similarity, i.e.: 
- Railroad locomotive and towboat;

- Mine locomotive and forklift truck.

Investigation of these latter applications, as discussed below, indicates that one in each pair offers a clearly superior opportunity for the PAFC to displace the conventional system. This more favorable application was chosen for further analysis.

PAFC offer the same basic advantages over the conventional system in both the railroad locomotive and the towboat: superior fuel efficiency. Comparison of efficiency figures shown in Tables 5.12 and 5.13 indicates that this efficiency advantage is substantially greater in the railroad locomotive case, where both the PAFC and the conventional diesel engine with generator are required to generate electricity to run a motor. This contrasts with the towboat, in which the conventional diesel engine is used to provide shaft power to the propellers, and competes against a fuel cell with $\mathrm{AC} / \mathrm{DC}$ converter plus electric motor. By choosing the unit train application of the railroad locomotive, it is possible to select a locomotive duty pattern which calls for operation for more than 5000 hours per year exclusive of idling, much of that at or near full load; a duty pattern comparable to that displayed by the busiest towboat. Therefore, the railroad locomotive applied to unit train duty was chosen in preference to the towboat, since it offers PAFC the opportunity to exploit a much larger fuel efficiency advantage and attendant fuel cost savings.

Consideration of the duty patterns of forklift trucks and mine locomotives indicate that the mine locomotive is much better suited to use of a fuel cell alone. Its duty pattern calls for long periods of sustained operation at or near maximum load. The forklift truck, by contrast, requires relatively large amounts of power during short periods of time, such as when lifting a load, and smaller amounts of power while carrying a load. It is unlikely that a forklift truck could effectively be designed to operate on a fuel cell only. Rather, a hybrid system would have to be developed which would include a large amount of battery capacity.

The need to use a fuel cell to recharge a periodically depleted battery bank would reduce the fuel cell's advantages over the simple battery because of the energy inefficiency of battery charge/discharge. The fuel cell/battery hybrid would consume more fuel per kilowatt hour and require more capital per average rate of power delivery than a simple fuel cell. By contrast, variability in load barely affects battery efficiency and battery cost per average rate of power delivery. Therefore, the comparable advantage of PAFC over battery power is greatest for the simple fuel cell application. 


\subsection{ANALYSIS BASIS}

The four applications selected for economic analysis are quite diverse. Therefore, each application was considered based on the application characterization premises, financial parameters, fuel costs, etc. appropriate to it. The broad outline for each application analysis, however, included the following common criteria:

- Application characterization;

- Estimation of size of the U.S. market:

- Capital cost analysis;

- Energy cost/savings analysis;

- Life-cycle cost comparison;

- Quantification of the export market;

- Discussion of conditions which most favor fuel cell viability, based on appropriate sensitivity analysis.

Application characterization begins with a general discussion of the conventional equipment (for example, all road locomotives). As appropriate to an application, it may be necessary to define in detail a particular class of duty in which the fuel cell would offer the greatest competitive advantage (i.e., unit train locomotives). Selection of such a favorable duty application is based on overall consideration of the added advantage the fuel cell offers in this class of duty and of the limitations which exclusive consideration of this class of duty places on market size.

For the selected application, an estimate is made of the gross size of the U.S. market. Included in the estimate is a projection of how that market might be expected to develop over time, and the rate of sales of replacement fuel cell stack for use in units previously sold.

Capital costs are evaluated based on information developed in the Hardware Data Base (Chapter 3 and Appendix A). Capital cost analysis for phosphoric acid fuel cell systems takes into consideration the decline in fuel cell system and replacement stack costs as a result of learning curve effects. These costs can be expected to decline as production experience accumulates and are calculated based on response to an $86 \%$ learning curve effect. To simplify the analysis, the same learning curve is attributed to the entire system. 
The basis of production which is considered to have brought fuel cell cechnology to the level reflected in the date base is $10 \mathrm{MW}$ of cumulative capacity. Thus, after $10 \mathrm{MW}$ of additional capacity has been produced and deployed (new systems and/or replacement stack), fuel cell system costs are expected to have declined by $14 \%$. After another $20 \mathrm{MW}$ of capacity have been built and deployed, another $14 \%$ decline is expected, and so on. Learning curve effects will be accounted for in the analysis of each application based on assumed capture by fuel cells of $100 \%$ of the U.S. market as defined previously; no learning curve effects will be credited for concurrent production of fuel cells for other applications for export.

Thus in an application which accounts for purchase of X MW of capacity (new and/or replacement stack) annually over a period of $Y$ years, capital cost of a system purchased at the end of year $Y$ would be reduced from those predicted in the Hardware Date Base by a factor of:

$$
\frac{\mathrm{CCy}}{\mathrm{CCP}}=\frac{\log \frac{10+\mathrm{XY}}{10}}{\log 2}=\left(\frac{10+\mathrm{XY}}{10}\right)^{-0.2176}
$$

From this equation it is possible to calculate the average unit cost of production during a period of $Y$ years subsequent to production of the first $10 \mathrm{MW}$. By integrating this equation over a period of $\mathrm{Y}$ years, these results:

$$
\frac{C C y}{C C p}=\frac{1}{X Y} \quad\left[1.278\left(\frac{10+X Y}{10}\right) 0.7824-1.278\right]
$$

In this equation, the first of the twosummed terms represents average capital costs from the time of first PAFC construction (i.e. preprototype) to the present.
The second term represents average capital costs for the first 10 megawatts of PAFC capacity.

By subtracting the second from the first, we calculate average postprototype costs (Reference $A$ and $B$ ). With fuel cell capital costs declining, especially during the initial years of production, it would be inappropriate to base comparative analysis of PAFC and conventional systems solely on costs to be paid by those who would buy during the first year of commercial production. Analysis will also be conducted based on the average capital cost paid by buyers purchasing PAFC systems over an initial production period of five years. This is based on the assumption that delaying of profitability on the part of the producer and ability of the consumer to place multi-year orders make an arithmetic average the appropriate capital cost in some cases. 
Energy costs are evaluated based on comparative efficiencies of the PAFC and conventional systems as calculated from the Hardware Data Base and on energy prices appropriate to the application. Thus, energy prices used in the evaluation of locomotives will be based on those projected in Chapter 3 for commerce in industrialized areas of the world. On the other hand, energy prices used in the evaluation of Arctic village power will reflect the much higher delivered cost of fuel at remote sites.

Life-cycle costs will be evaluated based on capital costs, operation and maintenance costs, and fuel savings. For simplicity of presentation, absolute capital costs are used as projected. It must be emphasized, however, that capital cost differentials are the key here, since the Hardware Data Base is expected to project these more accurately than absolute costs. Evaluation will be based on the difference between total annual costs, which include annual charges proportional to capital cost to cover return on investment, taxes, etc; thus the analysis can be said to be based on capital cost differentials rather than on absolute figures.

Operation and maintenance costs have two components:

- General expenditures for operation and maintenance of each system,

- Cost of replacement stack(s), if any, amortized over. system life.

The former are estimated, based on figures available in the literature, adapted judgmenta1ly to specific applications. They generally reflect the expectation that PAFC will require less general maintenance than conventional systems.

Two applications, the Arctic village power system and the railroad locomotive, will require replacement of the cell stack during system life. This is accounted as a maintenance cost, amortized over the system's 1ife. In the case of the Arctic village power system brought on line $X$ years after initial commercial use of PAFC in this application ( 3 replacement stacks required over the 20 year 1 ife), the following equation is used:

Annualized Cell Stack Replacement Cost:
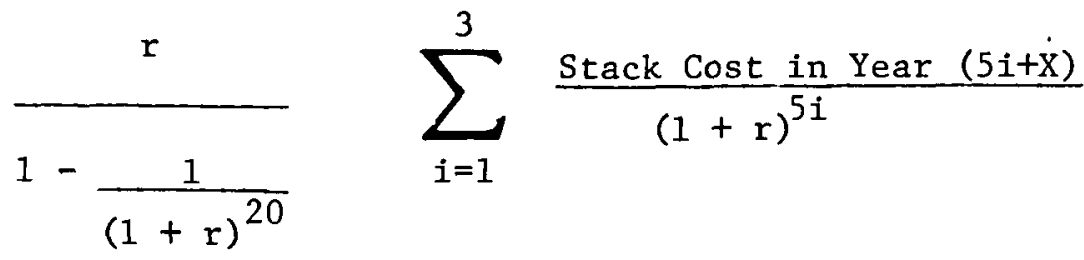

where $r$ is the cost of capital to the fuel cell system owner. Note that the equation accounts stack costs as a function of year of purchase, since they will continue to decline as a result of learning curve effects. 
The formulation is somewhat more complex in the railroad locomotive case, owing principally to the accounting of corporate income tax benefits of accelerated depreciation. Note that replacement stack costs must be accounted based on actual cost in year of replacement: this cost will decline over time, subject to the same learning effects as apply to new power systems.

It should be noted that, except in the case of the submersible, costs are for the power system only; the overall costs of railroad and mine locomotives and their operators are not included, neither is the salary paid to the Arctic village power system operator. For the submersible, the greater utility offered by PAFC allows it to do more work during a year of operation, which translates into less total cost per unit of useful work performed (analogous advantages of PAFC may exist in the case of the mine locomotive, but they could not be quantified in this study).

Estimates of the export market potential for fuel cell systems are probably less accurate than those made for the U.S. markets where U.S. vendor estimates are used. When sales figures are not available market size is inferred indirectly from data, such as Arctic population.

Finally, a general discussion is offered in the following sections on each application and the overall efficacy of using fuel cells. Necessary conditions for fuel cell economic viability and the sensitivity of those conditions to the key parameters considered in the analysis are also discussed.

\subsection{ARCTIC VILLAGE POWER}

\subsubsection{Application Characteristics}

Arctic villages vary in size from a few hundred inhabitants to perhaps 10,000. Their electricity demand and consumption vary more widely than this, owing principally to differences among settlements in industrial electricity use. For purposes of economic evaluation, a typical moderate size village with no significant industrial electricity use was chosen for analysis. This village uses $600,000 \mathrm{kWh}$ of electricity and a minimum summer demand of $50 \mathrm{~kW}$. Both demand and energy use are assumed to grow at a rate of $3.6 \%$ per year typical of the Alaskan Bush.

Currently, the village is served by a generating plant consisting of three high-speed diesel electric generators, each with a capacity of $150 \mathrm{~kW}$. Operating philosophy calls for having one or two units operating at all times, one unit on standby at all times and not more than one unit undergoing maintenance at any given time. Since peak demand is $200 \mathrm{~kW}$, operation of two units is often required during significant periods of the year. With one unit required on standby, this implies that no unit maintenance can occur during the peak winter demand months. Under these circumstances, it is common to add another generating unit to accomodate growing power requirements. 
It is proposed in this hypothetical case to add generating capacity in the form of a $100 \mathrm{~kW}$ PAFC power plant instead of adding another diesel unit. The intent would be to load the fuel cell, whenever it is physically operable, as follows:

- When demand is less than $100 \mathrm{~kW}$, use the fuel cell to supply all required electric power.

- When demand is greater than $100 \mathrm{~kW}$, use it in conjunction with a diesel generator, splitting the load between the two so as to minimize total fuel consumption.

For purposes of this analysis, it is assumed that the fuel cell is operated for 8000 hours per year, the balance of the year being required for planned and emergency maintenance. It is assumed that it achieves a load factor of $50 \%$, consistent with village load patterns and the need to share load with a diesel unit during high demand periods.

Economic evaluation is based on fuel cell purchase and ownership by a government agency, using $100 \%$ conventional debt financing. For base case evaluation, it is assumed that operating costs (principally payment of a part time attendant in the village) are essentially identical for the two systems. Since it is probably that the fuel cell will have lesser maintenance requirements than a diesel (exclusive of periodic stack replacement), and since maintenance in Arctic villages is very expensive (typically conducted by flying trained mechanics to the site), it is assumed that total PAFC maintenance costs are $\$ 10,000$ per year, less than the $\$ 15,000$ per year typical of diesel units.

Base case fuel prices considered in this analysis are twice the values developed in Chapter 3 , which are based on projected future world oil prices. Such costs are in fact typical of delivered fuel costs in the Alaskan Bush today. Possible impact on fuel cell economics of further increases in fuel costs will be considered in sensitivity analysis.

Opportunities exist in numerous Arctic villages to utilize much of the waste heat produced in power generation. No detailed analys is was made of this possibility, however, since diesel generators offer at least as much potential for waste heat utilization as phosphoric acid fuel cells.

\section{3 .2 U.S. Market}

Today, there is approximately 235 MW of diesel electric generating capacity installed in remote villages and towns in Alaska. Installed capacity can be expected to grow at an average rate of approximately $3.6 \%$ per year for the balance of this century, to keep pace with electricity demands and consumption growth in these communities. Furthermore, there is a substantial replacement market for these diesel generators, with annual replacements equivalent to approximately $5 \%$ of installed capacity. Thus, annual sales of new generating capacity amount to $8.6 \%$ of $235 \mathrm{MW}$, or approximately $20 \mathrm{MW}$. 
Fuel cells are technically suited to displace only a portion of this diesel generator capacity. Since fuel cells are not suitable for standby duty, it is likely that a village power system would need to include at least two diesel units based on reliability considerations. This suggests use of only one PAFC generating unit in each village, sized to constitute no more than $20 \%$ of village generating capacity or $50 \%$ of peak demand.

Presented with the opportunity to buy a fuel efficient PAFC generator system to add to existing diesel systems, many towns, village cooperatives, etc. might be expected to purchase such systems in the early years of their commercial availability. The situation would, however, quickly reach a point at which the market for such capacity was saturated, and future sales would consist primarily of replacement fuel cell stacks. Saturation could be expected to occur when installed fuel cell capacity equals between 15 and $20 \%$ of total installed generating capacity.

Consistent with this constraint, it is estimated, for a period of five years beginning with the first commercial offering of PAFC power systems, that half of this market, or $10 \mathrm{MW}$ per year, is captured by PAFC systems. Deployment of $50 \mathrm{MW}$ of capacity would essentially fill the fuel cell-compatible generating capacity needs in these communities.

As noted above, it is assumed that these PAFC systems will be operated whenever they are physically capable. If PAFC reliability expectations are met, this could readily lead to logging an average of 8,000 operating hours per year. Oh this basis, a stack could be expected to last five years. Thus, beginning in the sixth year of fuel cell commercial use, approximately $10 \mathrm{MW}$ per year of replacement stack would be required.

Thus, it is estimated that the U.S. market will amount to $10 \mathrm{MW}$ of new PAFC power system capacity in each of the first five years of commercial PAFC systems availability. No significant additional sales of new PAFC systems will be made until these have reached the end of their projected 20 year lives. Operated 8,000 hours per year, the stacks in these PAFC systems will last five years, then must be replaced. Thus, beginning with year six and continuing through year 20 of the 20-year cycle, $10 \mathrm{MW}$ of replacement stack will be sold each year.

It should be noted that this analysis is meant to serve as a basis for estimating national energy savings and the impact on capital costs of production learning curve effects; several finer points of market development were therefore not treated, for example:

- The market for PAFC power systems will not develop over night to the $10 \mathrm{MW}$ per year level. Sales in the first year of commercial fuel cell system availability will almost certainly be less than this; sales in some future years may be greater than $10 \mathrm{MW}$, and some new PAFC system sales will occur beyond the end of the fifth year in order to achieve the market saturation described above. 
- Occasional new PAFC power systems sales will be made after the fifth year of commercial system availability to serve a growing electric power load. They will be made primarily to power systems in larger settlements, which can use more than one PAFC power system as a complement to their diesels.

\subsubsection{Capital Costs}

Table 6.1 displays capital costs of power systems being considered for Arctic village application. The three columns of the table display initial capital cost on a prototype basis, averaged over the first year of production, and averaged over the first five years of production. Four candidate PAFC systems are considered, two using methanol and two using diesel fuel. For each fuel, one system concept uses a high power density cell stack and one uses a low power density cell stack. All use DC/AC inverters, and all have power sections operated at $500 \mathrm{kPa}$.

\section{$\underline{6.3 .4 \quad \text { Fue1 Consumption }}$}

Table 6.2 displays annual fuel consumption by competing Arctic village power systems, subject to varying numbers of operating hours and load factors. Fuel cell system energy consumption is projected based on an assumed constant system heat rate over the range of loads which the system will be expected to carry, equal to the heat rate exhibited at full load. Diesel engine generator heat rates are projected based on a linear rate of increase in hourly fuel consumption from $17.5 \%$ to $100 \%$ of full load fuel consumption at idle and full load respectively, believed to be appropriate for diesels used in this application.

Simplistically, fuel use in the various systems and therefore fuel savings with PAFC is accounted as if the comparison is to be made among $100 \mathrm{~kW}$ stand alone machines, all operated 8000 hours per year and all achieving load factors of $50 \%$ during operation. This introduces two contravening errors which are believed essentially to cancel one another.

- Without the fuel cell, these variable and mostly lower power demands would probably be met by a diesel larger than $100 \mathrm{~kW}$, generally operating at lower load factors, therefore lower efficiency than the $100 \mathrm{~kW}$ machine modeled here.

- Fuel cell efficiency, including turbo compressor, probably declines with declining load to an extent which will affect annual fuel consumption in a machine where load factor is $50 \%$.

As with capital costs, the differences among expected annual fuel consumption rates are more accurate than any one absolute fuel consumption projection. 
TABLE 6.1

ARCTIC VILIAGE POWER SYSTEM CAPITAL COSTS, \$1000'S

\begin{tabular}{|c|c|c|c|}
\hline Power System & $\begin{array}{c}\text { Capital Costs, } \\
\text { Prototype } \\
\text { Basis } \\
\end{array}$ & $\begin{array}{l}\text { Average } \\
\text { Capital Costs, } \\
\text { One Year of } \\
\text { Production } \\
\end{array}$ & $\begin{array}{l}\text { Average } \\
\text { Capital Costs } \\
\text { Five Years of } \\
\text { Production } \\
\end{array}$ \\
\hline $\begin{array}{l}\text { High Speed } \\
\text { Diesel Engine } \\
\text { with Generator }\end{array}$ & 47 & 47 & 47 \\
\hline $\begin{array}{l}500 \mathrm{kPa} \text { Low Power } \\
\text { Density Fue1 Cel1, } \\
\text { Methanol Fuel }\end{array}$ & 396 & 364 & 310 \\
\hline $\begin{array}{l}500 \mathrm{kPa} \text { High Power } \\
\text { Density Fuel Ce11, } \\
\text { Methanol Fuel }\end{array}$ & 274 & $\begin{array}{r}252 \\
-\quad\end{array}$ & 215 \\
\hline $\begin{array}{l}500 \mathrm{kPa} \text { Low Power } \\
\text { Density Fuel Cell, } \\
\text { Diesel Fuel }\end{array}$ & 463 & 426 & 363 \\
\hline $\begin{array}{l}500 \mathrm{kPa} \text { High Power } \\
\text { Density Fuel Cell, } \\
\text { Diesel Fuel }\end{array}$ & 346 & 318 & 271 \\
\hline
\end{tabular}


TABLE 6.2

BASE LOADED 100kW POWER SYSTEM FUEL CONSUMPTION, GJ/YR.

8,000 OPERATING HOURS PER YEAR, $50 \%$ LOAD FACTOR

Power

\author{
System \\ High Speed \\ Diese1 Engine \\ with Generator \\ $500 \mathrm{kPa}$ Low Power \\ Density Fuel Ce11, \\ Methanol Fuel \\ $500 \mathrm{kPa}$ High Power \\ Density Fuel Ce11, \\ Methanol Fuel \\ $500 \mathrm{kPa}$ Low Power \\ Density Fuel Cell, \\ Diesel Fue1 \\ $500 \mathrm{kPa}$ High Power \\ Density Fuel Cell, \\ Diesel Fuel
}

Full Load

Efficiency, $\%$

33.0

5127

40.3

3571

36.8

3912

37.4

3854

34.1

4222
Fue1

Consumption

GJ/Yr. 
Table 6.3 displays, using three different bases, energy savings attributable to use of the fuel cell. End-use energy savings are quite significant for the fuel cell systems, as is primary resource energy savings in a future economy in which both methanol and diesel might be based on coal. Primary resource savings appear to be minimized or even negative in the case of comparing use of petroleum derived diesel fuel in a diesel generator with natural gas-derived methanol in a fuel cell. It should be noted, however, that this small primary resource energy savings corresponds to a 100\% savings in petroleumbased energy. This foregone petroleum consumption, petroleum that would have been required to produce the diesel fuel to run a $100 \mathrm{~kW}$ diesel generator at $80 \%$ of rated load for 8000 hours per year, amounts to $5573 \mathrm{GJ}$ of petroleum.

6.3.5 Life-Cycle Cost.

Comparative evaluation of annualized life-cycle costs involves consideration of three separate components:

- Capital costs;

- Fuel costs;

- General operation and maintenance costs.

Annual charges to cover amortization of capital investment are assessed at $7.04 \%$ of the initial capital costs displayed in Table 6.2 , appropriate to constant dollar analysis of an investment to be financed entirely by sale of low risk government bonds (real interest rate $=3.5 \%$ ).

Fuel savings are accounted based on annual fuel consumption rates as projected in Table 6.2. Delivered fuel costs are accounted at $\$ 16 / G J$, typical of delivered costs in many Arctic villages today.

It is anticipated that, apart from periodic stack replacement, the diesel generator will have significantly greater maintenance requirements and costs than the fuel cell system. While such a cost differential might be quite modest in an application which enjoyed ready access to skilled maintenance capability, replacement parts, etc., it could be quite substantial in Arctic villages. Here maintenance is performed by personnel flown to the village from a major population center. If maintenance is being performed to repair an inoperable unit (i.e., unplanned maintenance), multiple round-trip flights may be necessary to deliver the required parts and skills to the village site. Based on recent Arthur D. Little work evaluating diesel power systems in such villages, it is projected that annual maintenance costs for a $100 \mathrm{~kW}$ diesel generator could approach $\$ 15,000$. It is not unreasonable to expect that the maintenance requirements for a fuel cell system would be significantly less expensive than for a diesel. For purposes of this analysis, maintenance cost figures of $\$ 10,000$ per year are projected for the fuel cell system and $\$ 15,000$ per year for the diesel system. 
TABLE 6.3

ARCTIC VILLAGE POWER ANNUAL ENERGY SAVINGS

BASED ON USE OF A $100 \mathrm{KW}$ FUEL CELL SYSTEM 8,000 HR/YR WITH A 50\% LOAD FACTOR

Fuel Cell System

$500 \mathrm{kPa}$ Low Power Density Fuel Cell, Methano1 Fue1

$500 \mathrm{kPa}$ High Power Density Fue1 Ce11, Methano1 Fue1

$500 \mathrm{kPa}$ Fuel Cell, Diesel Fuel

$500 \mathrm{kPa}$ High Power Density Fuel Ce1l, Diesel Fuel
Current

End Use Energy

Savings, Gj

1556

79

2829

2209

1273

1384

2315

905

984
Primary Resource*

Energy Savings Gj
Future

Primary Resource**

Energy Savings Gj

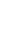


General operating costs, consisting primarily of salary paid a part-time attendant in the village, are assumed to be equal for the two systems and are not accounted here.

Annualized cost of replacement cell stacks are estimated according to the formula presented in Section 6.2, based on the assumption that the net installed cost of a replacement cell stack is equal to $90 \%$ of the cost of the complete PAFC power section (as defined in the Hardware Data Base). As noted previously, this cost must include the learning curve experience up to the time of replacement. Resulting costs are displayed separately from other operation and maintenance costs in Table 6.4.

Table 6.4 displays the resulting annualized comparative life-cycle costs for $100 \mathrm{~kW}$ generators placed in existing Arctic village power systems for 8,000 operating hours per year and a $50 \%$ load factor, broken down by cost account. The figures are based on average capital costs of PAFC systems purchased in the first year of commercial production. Table 6.5 displays analogous estimates of annualized costs, based on average PAFC capital costs for the first five years of production. Taking account of fuel and maintenance cost savings and of capital cost reduction due to learning curve effects, the fuel cell systems still cost more to own and operate than the diesel generator systems. Sensitivity analysis indicates that this holds true for all operating hours and load factors which are considered to be feasible.

\subsubsection{National Energy/Petroleum Savings}

Table 6.6 displays projected national energy savings and national petroleum savings based on installation $50 \mathrm{MW}$ of phosphoric acid fuel cell generating capacity in Arctic villages and operation of that generating capacity at an average load factor of $50 \%$ for an average of 8,000 hours per year. This is considered to be approximately the maximum level of fuel cell use in Alaska, accounting for approximately $60 \%$ projected power generation in the villages in the year 1990, the earliest possible date for achievement of such extensive fuel cell deployment.

\subsubsection{Export Market}

Three characteristics distinguish the Arctic village power application, making it a unique and small market:

- The villages are small and isolated from one another and from major population centers, making steam-based central power generation inappropriate. 


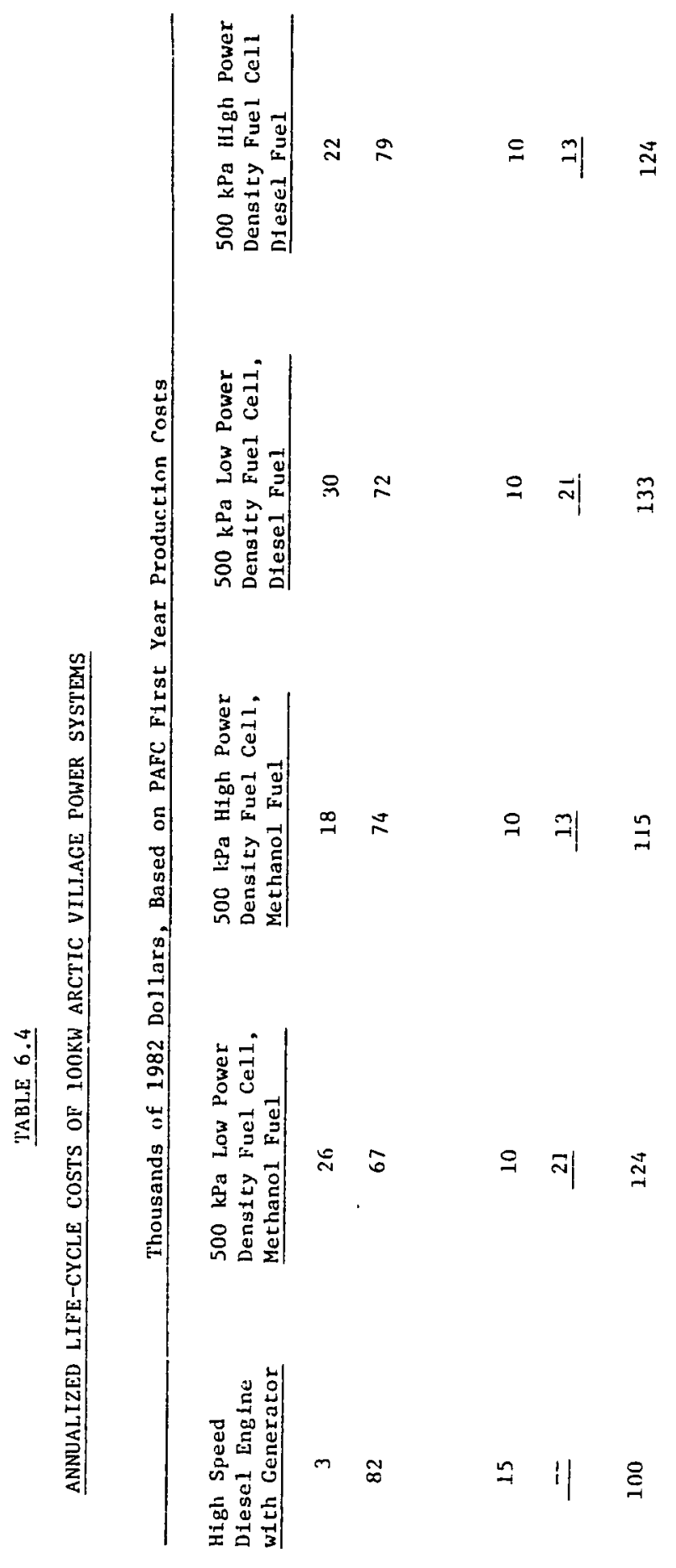

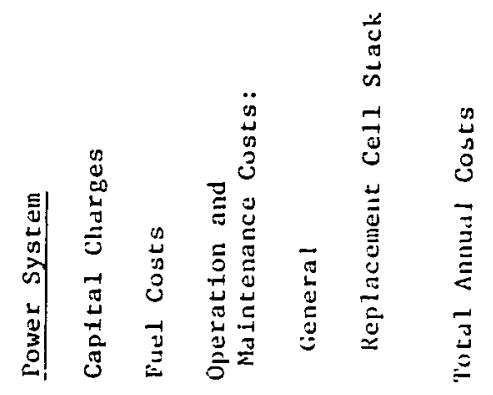$$
\text { 6-15 }
$$ 

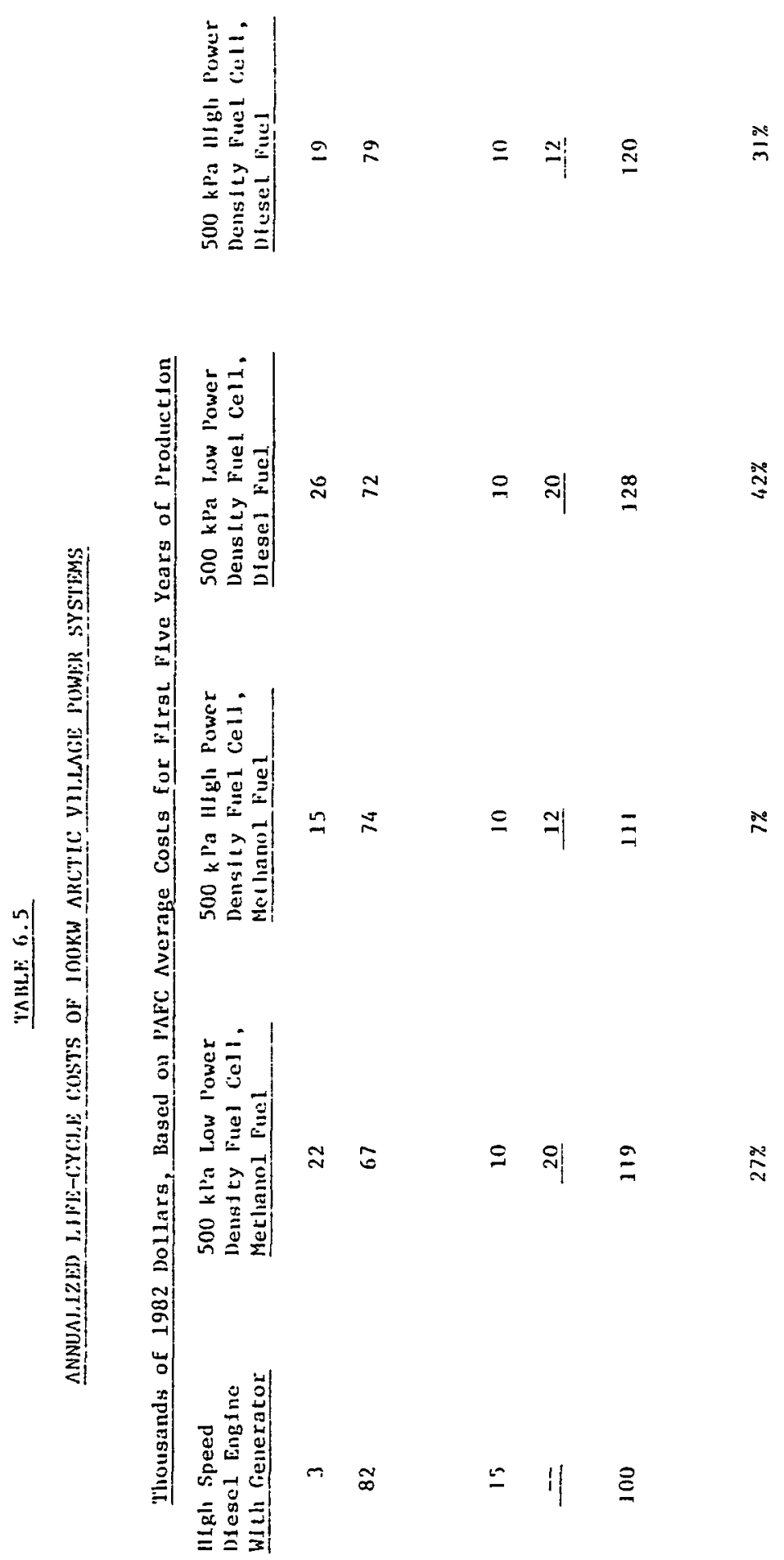

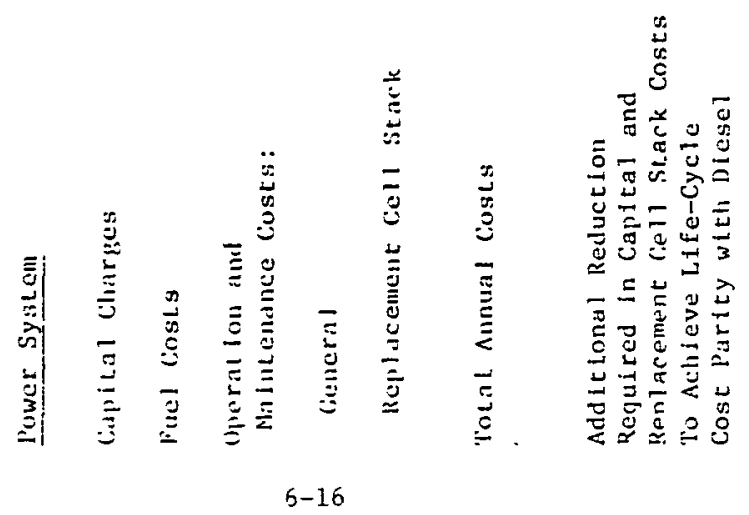


TABLE 6.6

NATIONAL ENERGY/PETROLEUM SAVINGS - ARCTIC VILLAGE POWER ANNUAL SAVINGS USING PAFC COMPARED TO DIESEL GENERATORS, TJ.

\begin{tabular}{|c|c|c|c|c|}
\hline $\begin{array}{l}\text { Fuel Cell } \\
\text { Svstem } \\
\end{array}$ & $\begin{array}{l}\text { End Use } \\
\text { Energy } \\
\text { Savings } \\
\end{array}$ & $\begin{array}{l}\text { Near Term* } \\
\text { Primary } \\
\text { Resource } \\
\text { Savings } \\
\end{array}$ & $\begin{array}{l}\text { Near Term* } \\
\text { Petroleum } \\
\text { Savings } \\
\end{array}$ & $\begin{array}{l}\text { Long Term*: } \\
\text { Primary } \\
\text { Resource } \\
\text { Savings } \\
\end{array}$ \\
\hline $\begin{array}{l}500 \mathrm{kPa} \text { Low } \\
\text { Power Density Fuel } \\
\text { Cell, Methanol Fuel }\end{array}$ & 778 & 40 & 2787 & 1415 \\
\hline $\begin{array}{l}500 \mathrm{kPa} \text { High } \\
\text { Power Density Fuel } \\
\text { Cell, Methanol Fuel }\end{array}$ & 608 & -223 & 2787 & 1105 \\
\hline $\begin{array}{l}500 \mathrm{kPa} \text { Low } \\
\text { Power Density Fuel } \\
\text { Cell, Diesel Fuel }\end{array}$ & 637 & 692 & 692 & 1158 \\
\hline $\begin{array}{l}500 \mathrm{kPa} \text { High } \\
\text { Power Density Fuel } \\
\text { Cell, Diesel Fuel }\end{array}$ & 453 & 492 & 492 & 823 \\
\hline
\end{tabular}

* Near term basis for methanol production is natural gas. Near term basis for diesel fuel production is petroleum.

$* *$ Long term basis for production of methanol and diesel fuel is coal. 
- The villages are located in political units which are part of or controlled by technologically advanced. countries; villagers have an expectation of having electricity as members of such a society.

- The villages are much too far from the equator to allow practical application of photovoltaic power generation, particularly since peak demand occurs in winter.

In the non-Communist world, the export market is limited to Canada, Greenland, a few isolated portions of Iceland and Scandanavia, the southern-most parts of Argentina and Chile and a few remote islands. An estimation was made of the size of the principal markets, Canada, and Greenland, based on the premise that the market for fuel cells in such areas is proportional to the population living in isolated communities with fewer than 10,000 inhabitants. The estimate was developed as follows:

- Take the 1980 population of Alaska (400,481). Subtract populations of all municipalities larger than 10,000 to yield a "rural population" of 160,009 . A portion of this rural population lives in villages which might be served by fuel cells.

- Take the 1981 populations of Greenland, the Yukon Territory, and the Northwest Territory and subtraci populations of ali municipalities larger than 10,000 to yield a rural population of 119,894 .

- Total the 1981 populations of British Columbia, Alberta, Saskatchewan, Manitoba, and Newfoundland and assume that $2 \%$, or 150,889 , live in rural isolated communities analogous to the rural populations estimated for Alaska, Greenland, etc.

- Total the 1981 populations of Ontario and Quebec and assume that $10 \%$, or 150,635 , live in such rural communities.

- Total the identified isolated rural populations of Canada and Greenland, yielding 421,418 people, 2.63 times the rural population of Alaska,

Then a preliminary estimate would show the Canadian and Greenland markets together to be approximately 2.6 times the size of the U.S. (Alaska) market. Performance of sensitivity analysis on estimate of the provincial Canadian market and inclusion of other possible market leads to an estimated total export market which is two to four times the size of the U.S. market, Probably developing in a slower, fragmented fashion, it might take the form of sales of 5-10 MW of new capacity 
each year, indefinitely, without saturating in five years as the Alaskan market is projected to do. Eventual rates of sales of replacement stack would total 15-30 MW per year.

Although excluded from the scope of this study, it should be noted that a substantial market probably also exists for Arctic power systems in military applications which are similar to village power. This market would include Alaska and all areas considered in the civilian export market.

\subsubsection{Circumstances for PAFC Viability}

Developments which favor economics. As the foregoing analysis indicates, PAFC is not competitive with diesel generators for application in Arctic villages. The barrier to PAFC viability is capital costs of the initial system and very high costs of replacement stacks. Prototype PAFC costs are much higher than diesel costs, and in this relatively small market, simple learning curve cost reduction effects are not expected to be sufficient to make PAFC viable, even on a life-cycle cost basis.

These very high capital and replacement stack costs result in annualized life-cycle costs which are significantly higher than those for diesel systems, despite some maintenance cost savings and quite substantial fuel cost savings already credited to the fuel cell. In addition, the much higher initial capital costs may themselves serve to deter deployment aside from their impact on life-cycle costs: "sticker shock."

Technical developments which would be most likely to lead to PAFC life-cycle cost parity with diesel generators would be those which would reduce initial system and replacement stack costs oyer and above reductions attributed to learning curve effects as accounted above. Such reductions might result from:

- Improvements in cell performance;

- Major cost reductions resulting from transition from prototype to initial commercial production;

- Accelerated learning curve cost reduction effects resulting from concurrent production of Arctic village PAFC systems for export and/or of PAFC systems designed for other uses.

Fundamental improvements in cell performance would allow new cells to operate at the same current density as the current model while achieving higher cell voltage, with proportionately higher efficiency and power density, or it could operate at the same voltage and efficiency as the current model, but at much higher current and power densities. of greatest importance for reducing capital costs is the increase in power density, which is inversely proportional to required cell area and therefore approximately inversely proportional to capital costs. 
Opinions vary on applicability of a simple learning curve to predict cost reductions from the prototype cost level. Some investigators suggest that learning curve effects are only valid from the time that initial commercial production has begun. The step from prototype to commercial production may itself yield capital cost reductions which substantially exceed those accounted simply by a learning curve. Thus, it is possible that the development of any market which supports construction of a fuel cell assembly line may result directly in large reductions in initial system and replacement stack costs over and above those projected in Table 6.1.

of course, learning curve-based cost reduction may occur in response to concurrent PAFC production for other markets. As noted previously, such effects are not accounted in this economic analysis; the intent here is to identify individual applications which may be economically viable on their own.

Conceptually, a fourth mode of cost reduction presents itself: lengthening of stack life. As can be seen in Tables 6.4 and 6.5 replacement stack costs account for approximately the same portion of annualized life-cycle costs of a PAFC village power system as to initial capital costs, based on a stack life of 40,000 operating hours. Doubling stack life would reduce the equivalent discounted cash flow capital cost quite substantially; enough to make a PAFC system competitive in an Arctic village application even at prototype costs. Consideration of the technical issues involved, however, leads to the conclusion that such a substantial increase in stack life is quite unlikely; if anything, 40,000 hours may be too long. It is far more likely that the necessary cost reduction can be accomplished via improved cell performance and/or as a result of transition from prototype to commercial production.

The possibility of cost reduction by any of these effects raises the question of how large a reduction would be required in order to achieve life-cycle costs equal to those exhibited by the diesel engine with generator. Such percent reductions are shown at the bottom of Table 6.5 , and range from $7 \%$ to $42 \%$ of the capital costs shown in the third column of Table 6.1.

While the $7 \%$ figure may seem 1 ike a very modest cost reduction, it would simply achieve life-sycle cost equality with diesels. Fuel cell deployment almost certainly will not occur unless it offers significant life-cycle cost savings. Such incentive is required: 
However, higher future delivered prices of diesel fuel conceivably could improve the viability of the diese1-based PAFC system. With no improvement in PAFC system capital costs, fuel costs would have to increase to approximately $\$ 28 / G J$ in order for increased fuel costs alone to make the diesel-based PAFC system competitive with the conventional diesel engine generator.

All foregoing analysis of PAFC viability in Arctic village applications is contingent on the solution of two sets of design problems peculiar to this application:

- Adaptation for long-term operation by unsophisticated personnel, with little and infrequent access to sophisticated maintenance capability.

- Adaptation of a design which involves substantial internal handling, treatment, storage, and use of water or operation in an Arctic climate.

In addition to solving these problems peculiar to this application, PAFC system viability will require full development of hardware such as the high power density cell stacks. Most development to date has focused on low power density/high efficiency systems, but high power density systems appear to be much more attractive for use here, given the high cost of cells in the initial years of use. Also requiring additional development are the low temperature steam reformer and, in the diesel fuel case, the two-stage reformer processor system.

\subsection{RAILROAD LOCOMOTIVE}

\subsubsection{Application Characteristics}

Technical analysis of the railroad locomotive application indicated that the fuel cell offers one key advantage: superior fuel efficiency. This advantage over the diesel is amplified in this case compared to other vehicular applications because both systems must produce electricity to run motors; the diesel's shaft power cannot be used directly. It also appears that the fuel cell's added weight and volume are not expected to be a problem here in contrast with most other vehicular diesel applications. Taken together, these two effects lead to the preliminary conclusion that the railroad locomotive is the most promising vehicular application for fuel cells to displace diesels.

In order to maximize cost savings resulting from the fuel efficiency advantage of the fuel cell, the fuel cell locomotive should be used in those applications which involve large numbers of annual operating hours and high load factors throughout the year. A large annual cost savings on fuel is required to compensate for the substantially higher capital cost of the fuel cell system. Railroad locomotives exhibit a wide range of duty patterns, ranging from 
switchyard to unit train applications. It is this latter class that was chosen for consideration both because of its high duty and because it is a major use of locomotives in the United States.

A unit train, by definition, is an assembly of locomotives and cars which are seldom uncoupled from one another, but simply haul one commodity from one point to another on a dedicated basis. By far the most common application of unit trains is for hauling coal to electric power plants and to seaports. Also hauled by unit trains are phosphate rock, grain, and various ores.

Table 6.7 displays the patterns of duty for general freight road locomotives (that is, an industry average of the duty exhibited by freight locomotives used for hauling freight on the road, as opposed to moving freight about the railroad yard) and for unit train locomotives. The two load patterns are quite similar except that the unit train locomotive spends 1,300 more hours per year at ful1 load than does the general freight road locomotive, and 1,300 hours per year less at idle. This unit train locomotive duty pattern is used in the economic and fuel savings analysis for fuel cell powered vehicles.

Economic evaluation of the PAFC locomotive is based on locomotive purchase with funds raised via sale of securities in an 80/20 debtequity ratio, typical of locomotive finance. Cost of labor to operate a fuel cell-based or a diesel-based locomotive are expected to be the same and are not considered further. Cost to maintain the diesel locomotive is estimated to be $\$ 75,000$ per year, compared to $\$ 65,000$ for the fuel cell locomotive, exclusive of stack replacement, which is accounted separately.

Base case fuel prices considered in this analysis are identical to the values developed in Chapter 3, which are based on projected future world oil prices.

\section{4 .2 U.S. Market}

Approximately 1,400 large, heavy duty railroad locomotives are sold for use in the United States each year. These locomotives, intended for road duty at least in the early years of their lives, are mostly rated at or near 3,000 horsepower of drawing power, and require a DC power generation capability of $2,237 \mathrm{~kW}$. The population of road locomotives is nearly constant; the market is essentially a replacement market. Locomotive life varies from 15 years for unit trains to 20 years for general freight duty. It is not uncommon for locomotives to be demoted from unit train to general freight road duty to yard duty over their lives.

Consideration of total locomotive sales per year, probable total unit train locomotive population and the attendant unit train locomotive fuel consumption lead to an estimate of possible PAFC locomotive sales for unit train duty equal to 280 units per year, or $20 \%$ of the total road locomotive market. It is expected that this rate of sales could 
TABLE 6.7

RAILROAD LOCOMOTIVE DUTY PATTERN

Power Setting/ Duty Class

Idle (Zero Power)

$15 \%$ of Fu11 Load*

$50 \%$ of Full Load

Ful1 Load

Shop Time
General Freight Road Locomotive

3,889 Hours/Year

1,555 Hours/Year

889 Hours/Year

1,556 Hours/Year

877 Hours/Year
Unit Train Locomotive

2,556 Hours/Year

1,600 Hours/Year

889 Hours/Year

2,844 Hours/Year

877 Hours/Year

*Includes dynamic braking. 
- to overcome "sticker shock" at the higher capital cost;

- to make delivery and use of two power generation fuels worthwhile (the methanol fueled PAFC systems are significantly more attractive than the diesel fueled systems);

- to compensate for technical risks taken in use of a less mature system;

- to compensate for risk of deploying an expensive, relatively sophisticated system in a setting characterized by harsh operating conditions and poor maintenance.

For all these reasons, substantial additional capital and replacement stack cost reductions would be required if such cost reductions alone are to establish the economic viability of PAFC Arctic village power.

Capital cost reduction is the key; further improvements in the other principal cost component, fuel cost, is unlikely to make the PAFC system viable. Fuel cost savings are already projected to be quite substantial, with fuel consumption of the low and high power density methanol-fueled PAFC systems being $70 \%$ and $76 \%$ that of the diesel generator, respectively, and that of low and high power density diesel fuel systems being approximately $75 \%$ and $82 \%$ that of a diesel engine generator, respectively. Furthermore, these fuel savings are based on projected efficiencies of fuel processor and power processor subsystems which approach thermodynamic limits and cannot be expected to improve significantly beyond that projected in the Hardware Data Base (if in fact those levels can be achieved). Any improvements in cell performance which might be manifested in increased cell voltage at a given current density almost certainly could be utilized more economically to increase current and power density, maintaining approximately the efficiency levels projected in the Hardware Data Base while reducing required cell stack area, therefore reducing capital costs.

It is also unlikely that competition between a methanol based PAFC system and a diesel generator would change in favor of the PAFC system as a result of further increases in delivered fuel prices in the Arctic villages. The $\$ 16 / G J$ diesel fuel cost projected here includes an allowance for delivery to the village of $\$ 8$ per gigajoule or $\$ 0.30$ per liter. To be competitive in terms of delivered cost in the village, methanol must enjoy a significantly lower production cost per gigajoule and significantly lower delivery costs per liter than diesel fuel, because the heating vilue of methanol per liter is approximately half chat of diesel fuel, requiring delivery of twice as much methanol as diesel fiel. Circumstances which might result in higher costs for delivery of diesel fuel to the village could also be expected to drive up the delivered cost of methanol, possibly by more per gig joule since delivery of mechanol to the village aldires movemint of twice as mary liters as diesel fuel. 
be sustained for only 7.5 years. During this time, fuel cell locomotives would replace retired unit train locomotives, and cause displacement of newer diesel unit train locomotives to lower load factor duty. After sales at this rate for 7.5 years, these PAFC locomotives would approach $10 \%$ of the locomotive population. Sales of unit train locomotives which could be expected to exhibit the high load factors projected in Table 6.7 would be saturated at this point. No further sales of new PAFC locomotives would then occur until these units began reaching the end of their useful lives, 15 years after the beginning of PAFC locomotive sales.

A locomotive performing the unit train duty shown in Table 6.7 would exhibit a stack life of 7.5 years. On this basis, it is projected that stack replacement would be required for 280 locomotives per year, beginning after PAFC locomotives had been offered commercially for 7.5 years. Such replacement stack sales could be expected to continue until the end of the fifteenth year following intial commercial offerings, at which point complete replacement of these first PAFC locomotives would begin. Thus, a steady state market for PAFC stacks either in new units or for replacement in existing units is envisioned. This would be equivalent to 280 locomotives, or $626 \mathrm{MW}$ per year indefinitely.

These simplified projected sale patterns are used for evaluation of learning curve effects on capital costs and of national energy savings potential. It is recognized that the actual PAFC locomotive market will not develop overnight as is projected here, but will grow gradually over a period of years. It is estimated, however, that sales in some future years might be greater than $626 \mathrm{MW}$, as railroads, confronted with the opportunity to buy a very fuel-efficient locomotive would do so, demoting diesel locomotives from unit train duty to lighter duty applications.

\subsubsection{Capital Costs}

Table 6.8 displays capital costs of alternate power systems for locomotive application. Capital costs are displayed on three bases:

- prototype costs, shown as examples only.

- average cost for the first year of production, to be used in one life-cycle cost analysis case.

- average cost for the first five years of production, to be used in a second life-cycle cost analysis case.

Two fuel cell systems are considered: one using a highly efficient, low power density cell stack, the other a less efficient but less expensive high power density cell stack. Both use methanol as fuel; the fuel processor for using diesel fuel would substantially exceed weight and volume allowances. Both produce regulated DC power. 
TABLE 6.8

$2237 \mathrm{KW}$ UNIT TRAIN LOCOMOTIVE

POWER SYSTEM CAPITAL COSTS, \$1000's

\section{Power System}

Medium Speed

Diese1 Engine

with Generator

$500 \mathrm{kPa}$ Low Power

Density Fuel Cell,

Methanol Fuel

$500 \mathrm{kPa} H i g h$ Power

Density Fuel Cell,

Methanol Fuel
Average Capital

Costs, One Year

Capital Costs,

Prototype Basis

1,480

1,480

3,360

2,410

4,270

2,160

$$
1,480
$$

6,640$$
2,410
$$

1,550
Average Capital

Costs, Five Years of Production 


\subsubsection{Fue1 Consumption}

Table 6.9 displays comparative unit train. iocomotive fuel consumption, broken out by levels of locomotive duty. Variations in diesel electric generator efficiency with load are based on published fuel consumption data on power generation at eight standard throttle "notch points." As can be seen, this locomotive diesel operates much more efficiently at low loads than does the stationary diesel characterized for use in Arctic village power generation. Such low load and idle efficiency are absolutely necessary in a locomotive application, where much time is spent idling.

Annual PAFC fuel consumption rates are based on data available in the literature for $100 \%$ and $50 \%$ of rated 1 oad, augmented by two important assumptions at lower loads. First, it is assumed that a power system of this size designed explicitly for locomotive application, would allow for very high efficiency operation at $15 \% 1$ oad. The efficiency could be as high as that exhibited at higher loads, achieved possibly by compartmentalizing the fuel cell system and allowing sections to fall back to an idling status, while leaving smaller portions to carry the small loads at output rates near their rated capacity. Second, the accounting of fuel consumption assumes that a phosphoric acid fuel cell power system can be developed which will have extremely low rates of fuel consumption when in a condition of hot standby. While this is of some significance for system economics, and while the economic analysis conducted here is based on the unrealistically optimistic assumption that hot standby can be maintained with zero fuel consumption, the exact rate of hot standby fuel consumption is not critical to the analysis of this application. If PAFC idle fuel consumption were equal to that of the diesel system, such fuel consumption would reduce the annual fuel consumption advantage of the fuel cell by only $6.7 \%$ for the low power density system or $8.3 \%$ for the high power density system.

Table 6.10 displays annual energy savings from use of either low or high power density PAFC locomotives in place of a diesel locomotive. In both cases, end use savings are quite substantial, as are long-term resource savings. Near-term primary resource savings are very small for the more efficient PAFC and actually negative for the less efficient high power density system; however, they correspond to very large nearterm petroleum savings of 100 terajoules per year per locomotive.

Similar calculations, based on the general freight locomotive duty pattern reported previously show annual energy savings which are approximately $75 \%$ of those displayed for the unit train application. Once again, these energy savings are based on the unrealistically optimistic assumption of a PAFC system maintained in a hot standby condition with zero fuel consumption. Fuel savings and overall economics of the general freight locomotive application of PAFC are significantly more sensitive to actual achievable PAFC idle fuel consumption rates, since this locomotive duty pattern involves far more hours per year spent at idle than does unit train duty. 


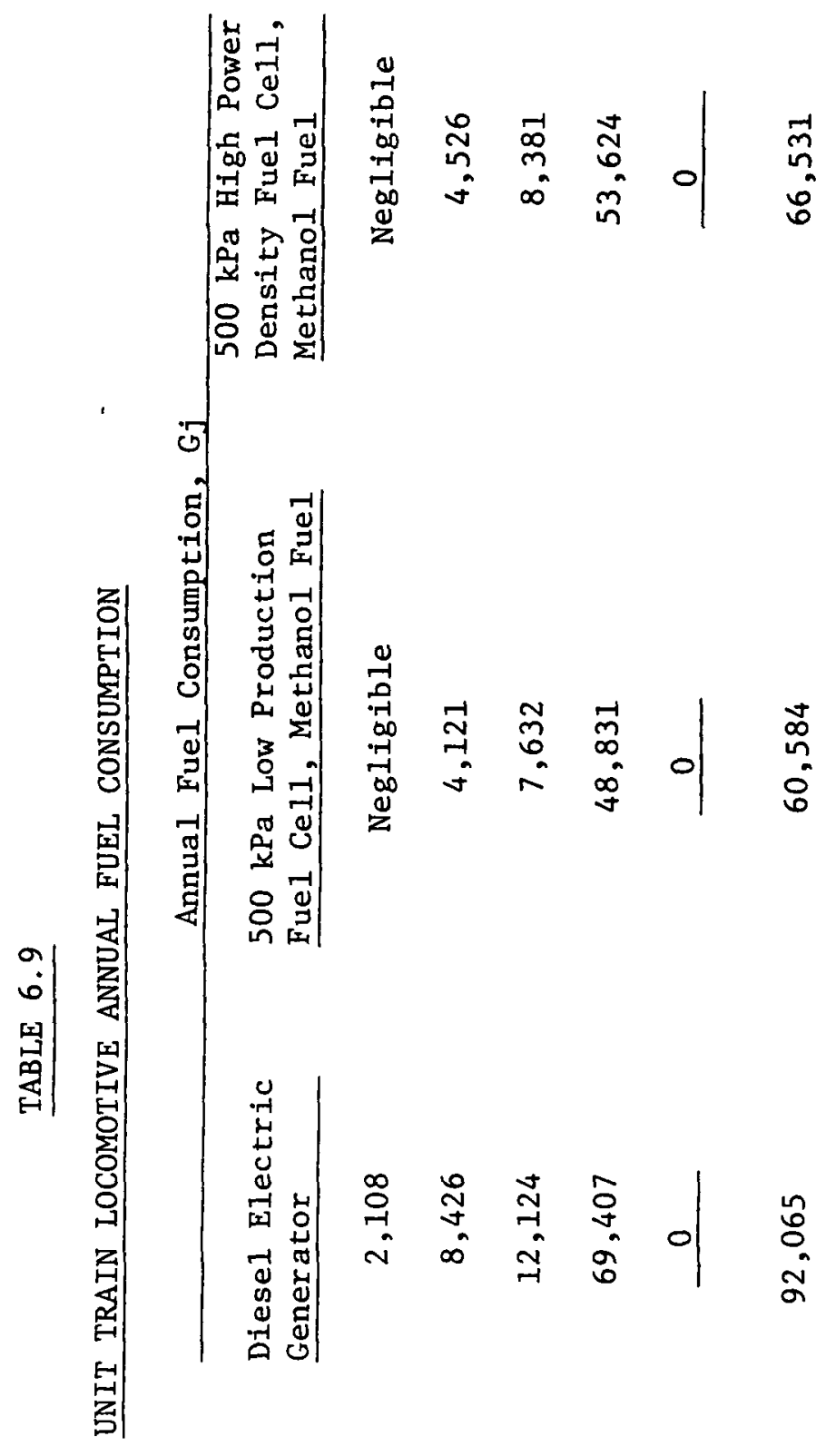

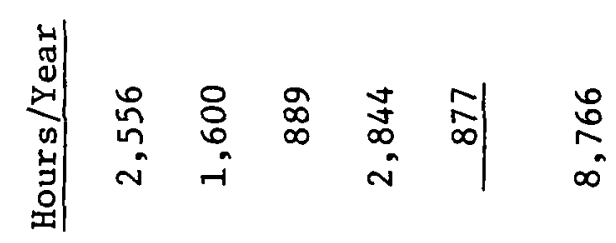

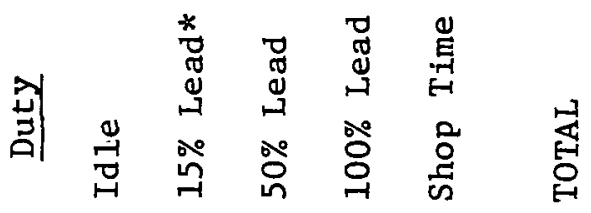


TABLE 6.10

$\frac{\text { ENERGY/PETROLEUM SAVINGS }-}{\text { USING PAFC COMPARED TO DIESEL GENERATORS }}$

Low Power

Density

Fuel Cell

High Power

Density

Fuel Ce11

End Use Energy Savings

31

25

Near Term Primary Resource Savings*

7

$-2$

Near Tern Petroleum Savings*

100

100

Long Term Primary Resource Savings**

57

46

\footnotetext{
*Near term basis of methanol production is natural gas. Near term basis of diesel fuel production is petroleum.

**Long term basis of methanol and diesel fuel production is coal. Since both are based on coal, PAFC offers no comparative petroleum savings.
} 


\subsubsection{Life-Cycle Costs}

Comparative evaluation of annualized life-cycle costs involve consideration of three separate cost accounts:

- Capital costs;

- Fuel costs;

- General operation and maintenance

Annual charges to cover amortization of capital investments are assessed at $90 \%$ of the initial capital costs displayed in the last two columns of Table 6.8.

Fuel savings are accounted based on annual fuel consumption rates.as projected in Table 6.9. Fuel costs to the railroad are assumed to be $\$ 8$ per gigajoule.

The cost of operating labor is estimated to be essentially identical for the two locomotive systems. Since this analysis is based on the assumption that the two locomotives will be exactly the same tasks over the course of the year, and incur exactly the same expenditure for operating labor in doing those tasks, there is no need to account for that operating labor in the comparison of the two.

Apart from periodic stack replacement, it is expected that the fuel cell will exhibit significantly lower maintenance requirements than will the diesel engine generator. Conservatively a maintenance cost differential of $\$ 10,000$ per year is estimated, based on work by the Jet Propulsion Laboratory (Reference $C$ ). This estimated differential may in fact be significantly smaller than would actually be exhibited by the competing systems.

One complete replacement ce11 stack is required for each PAFC locomotive after 7.5 years of operation. Its cost, accounted as an annualized maintenance cost, is based on procurement and installation of equipment at a total cost equal to $90 \%$ of the cost of a complete new power section. As with other PAFC equipment, its cost is reduced from prototype levels by $86 \%$ learning curve effects.

Table 6.11 presents the resulting annualized life-cycle costs of competing PAFC and diesel engine systems, with PAFC capital costs based on average production costs in the first year of PAFC locomotive production. Analogous figures are presented in Table 6.12, with PAFC capital costs based on average production costs during the first five years of production. PAFC appears to offer significant life-cycle cost savings, particularly the less expensive, high power density systems. Cost savings are apparent even for locomotives bought at costs equal to ayerage production costs in the first year of locomotive production. 
TABLE 6.11

ANNUALIZED LIFE-CYCLE COSTS FOR $2237 \mathrm{KW}$ RAILROAD LOCOMOTIVE

POWER SYSTEMS

Thousands of 1982 Dollars, Based on PAFC Average Cost for the First Year of Production

\begin{tabular}{|c|c|c|c|}
\hline Power System & $\begin{array}{c}\text { Medium Speed } \\
\text { Diesel Engine } \\
\text { with } \\
\text { Generator } \\
\end{array}$ & $\begin{array}{l}500 \mathrm{kPa} \text { Low } \\
\text { Power Density } \\
\text { Fuel Cell, } \\
\text { Methanol Fuel }\end{array}$ & $\begin{array}{l}500 \mathrm{kPa} H i g h \\
\text { Power Density } \\
\text { Fuel Cell, } \\
\text { Methanol Fue1 }\end{array}$ \\
\hline Capital Charges & 133 & 302 & 194 \\
\hline Fuel Costs & 737 & 485 & 532 \\
\hline \multicolumn{4}{|l|}{$\begin{array}{l}\text { Operation and } \\
\text { Maintenance Costs: }\end{array}$} \\
\hline General & 75 & 65 & 65 \\
\hline Replacement $\mathrm{Cell}$ & Stack & 65 & 39 \\
\hline Total Annual Costs & 945 & 917 & 830 \\
\hline
\end{tabular}


TABLE 6.12

ANNUALIZED LIFE-CYCLE COSTS FOR 2.2.37 KW! DAILROAD LOCOMOTIVE

POWER SYSTEMS

Thousands of 1982 Dollars, Based on PAFC Average Cost for the First Five Years of Production

\begin{tabular}{|c|c|c|c|}
\hline Power System & $\begin{array}{c}\text { Medium Speed } \\
\text { Diese1 Engine } \\
\text { with } \\
\text { Generator } \\
\end{array}$ & $\begin{array}{l}500 \mathrm{kPa} \text { Low } \\
\text { Power Density } \\
\text { Fuel Cell, } \\
\text { Methanol Fuel }\end{array}$ & $\begin{array}{l}500 \mathrm{kPa} \text { High } \\
\text { Power Density } \\
\text { Fuel Cell, } \\
\text { Methanol Fuel }\end{array}$ \\
\hline Capital Charges & 133 & 217 & 140 \\
\hline Fuel Costs & 737 & 485 & 532 \\
\hline \multicolumn{4}{|l|}{$\begin{array}{l}\text { Operation and } \\
\text { Maintenance Costs: }\end{array}$} \\
\hline General & 75 & 65 & 65 \\
\hline \multicolumn{4}{|l|}{ Replacement } \\
\hline Vent slacks & - & 02 & 3 \\
\hline Total Annual Costs & 945 & 829 & 774 \\
\hline
\end{tabular}




\subsubsection{Nationa1 Energy/Petroleum Savings}

Table 6.13 displays potential national energy savings. Perhaps of greatest significance is the opportunity to displace 210,000 terajoules of petroleum per year with natural gas-based methanol. This corresponds to approximately 12,700 tons of petroleum per day, or approximately $0.6 \%$ of current petroleum use in the United States.

\subsubsection{Export Market}

Sales of large diesel locomotives in the non-Communist world outside of the United States are estimated to total approximately 4,000 units per year. Simplistically, this would imply fuel cell locomotive sales of approximately 800 units per year. Far greater uncertainty must be attached to this estimate than to the estimate for the United States, however, because:

- Overall market figures are inaccurate, due to the fragmented nature of this market. Many industrialized nations which individually constitute significant markets are served exclusively by one or more domestic manufacturers, protected by "local content" and similar laws. Such markets might be especially difficult to penetrate, even with a superior product.

- The importance of high-duty operation of locomotives in rail systems of other countries is not known. Specifically, the fraction of total locomotive sales accounted to unit trains is not known.

Given the basis of unit train use in the United States--moderate to long-distance coal hauls--and the lesser importance of such coal haulage to rail systems elsewhere in the world, we estimate that the actual export market would be significantly less than 800 units per year. Therefore, 400 units per year was chosen, corresponding to 895 MW of fuel cell capacity per year.

\subsubsection{Conditions for PAFC Viability}

\subsubsection{Developments Which Favor Economics}

Based on the analysis presented above, it appears that PAFC is economically competitive with a diesel generator as a power system for a unit train locomotive. This conclusion is sensitive to assumptions concerning fuel cost savings resulting from use of PAFC, but most of a11 to assumptions concerning prototype costs of both the low and high power density fuel cell systems and future learning curve related reductions in capital costs. The high power density system appears to be substantially more attractive economically, owing to the $40 \%$ smaller cell area requirement and the associated reduction in power section capital costs. Whether such a system could be built, achieve these capital 
TABLE 6.13

\section{NATIONAL ENERGY/PETROLEUM SAVINGS - UNIT TRAIN LOCOMOTIVES SAVINGS USING PAFC COMPARED TO DIESEL GENERATOR, $\underline{T J} / Y \mathbf{r}$}

\section{Low Power Density Fuel Cel1}

End Use Energy Savings

Near Term Primary Resource Savings*

Near Term Petroleum Savings*

Long Term Primary Resource Savings**

$$
66,000
$$$$
14,000
$$$$
210,000
$$$$
120,000
$$

High Power Density Fuel Cell

$$
53,000
$$$$
-2,000
$$

210,000

97,000

\footnotetext{
* Near term basis of methanol production is natural gas. Near term basis of diesel fuel production is petroleum.

**Long term basis of methanol and diesel fuel production is coal. Since both are based on coal, PAFC offers no comparative petroleum savings.
} 
cost savings, and suffer no greater performance penalties than projected here is less certain than the data projected for the low power density case because essentially all large scale hardware development done to date has been based on cell performance regimes typical of those used in the low power density system. Successful commercial development of a high power density system would contribute substantially to establishing the economic viability of PAFC as a locomotive power system.

The capital cost reductions projected from the levels calculated from the Hardware Data Base (a $49 \%$ cost reduction for first production year basis and $64 \%$ for first five production year basis) are quite large. Achievement of such a capital cost reduction is dependent upon:

- Rapid, successful development and exploitation of market which is enormous in comparison with past and present fuel cell commerce.

- Achievement of manufacturing cost reductions consistent with an $86 \%$ learning curve.

The first requirement for achieving the projected learning curve cost productions is to develop and exploit a market that size. It is equivalent to $20 \%$ of road locomotive sales to the railroads, traditionally considered to be a very conservative industry. More important, it would require manufacture of fuel cell generating capacity in each year beginning with the very first year of sales equivalent to approximately 60 times all phosphoric acid fuel cell generating capacity fabricated through the end of 1982. How effectively such a market could be developed and then serviced by manufacturers is far less certain in this application than any other application considered here.

The analysis done here simplistically projects cost reduction based on an $86 \%$ learning curve effect. Problems associated with the immense production scale-up required for this application may limit cost reduction in initial years of production to levels lower than implied by this learning curve. On the other hand, greater manufacturing economies of scale may serve to increase cost reductions beyond the $86 \%$ learning curve level. In any case, life-cycle cost of PAFC locomotives is far more sensitive to the learning curve rate actually achieved than are other applications due to the much larger cumulative PAFC production.

Despite the projected capital cost reductions expected to result from learning curve effects during the initial year of production, the fuel cell is still $\$ 300$ (high power density) to $\$ 840$ (low power density) per $\mathrm{kW}$ more expensive than the diesel engine generator conventionally used in locomotives. Capital charges assessed annually on this differential must be offset by very substantial savings in fuel costs. As noted in Table 6.12 , the fuel cell does save very substantial quantities of fuel on an end-use basis. Assuming that methanol and diesel fuel cost the same ( $\$ 8$ per GJ), these savings translate directly into large 
annual financial savings, perhaps as much as $\$ 250,000$ per locomotive per year. The projected financial savings are dependent upon the assumed price parity of methanol and diesel fuel; if fuel markets do not evolve in the future to produce this parity, the attractiveness of the fuel cell will be seriously impaired.

The estimation of a $\$ 10,000$ per year savings in maintenance costs with the use of a fuel cell compared to a diesel is probably conservative. However, it should be noted that this $\$ 10,000$ differential is only approximately $1 \%$ of annual cost of owning and operating either locomotive. Variations in these maintenance cost savings are not likely to have a significant impact on the viability of the fuel cell locomotive.

Even if the projected life-cycle cost advantages are realized, there will still be resistance to use of PAFC as a locomotive power system because of its higher capital cost. Exactly what level of lifecycle cost savings will be required to induce railroads to use this more capital-intensive technology cannot be predicted.

\subsubsection{Requirements for Technical Viability}

Two essentially developmental technical problems must be resolved in order for the PAFC to be a viable candidate for use as a locomotive power system:

- Achievement of the volume projected by the Hardware Data Base; and

- Development of an acceptable approach to idle/low load operation.

As pointed out in the preceding chapter, the PAFC system weight (both high and low power density) is projected to be such that it could be substituted for the diesel generator and a portion of the ballast typically used in a unit train locomotive. Unless the data base seriously underestimates the difference between PAFC and diesel generator weights, PAFC system weight will not pose problems in locomotive applications.

The Hardware Data Base projects a volume differential between the low power density PAFC and diesel generator systems which appears to be accommodatable on the locomotive, albeit with some minor difficulties. If the Hardware Data Base significantly underestimates this volume differential, it is unlikely that a PAFC system can be accomodated within the traditional locomotive envelope which will achieve the same power rating as the standard diesel generator.

As noted previously, all road locomotives spend substantial amounts of time in a state of idle including unit train locomotives. This results from the need to perform some duties which require very substantial power variations over short times and to be prepared to provide motive. 
power on very short notice. Given the time required to start up a phosphoric acid fuel cell from a cold condition, it must be expected that a PAFC system will have to be capable of sustaining a condition of hot standby for long periods of time (generally not exceeding 12 hours) and for a substantial fraction of system calendar life. It is essential for system economic viability that time spent in this hot standby condition not contribute in any significant way to the aging of the fuel cell. It is also desirable that maintaining the fuel cell in this condition of hot standby consumes as little fuel as possible. Development of design concept and operating procedures to meet these requirements is essential to design and fabrication of a practical locomotive power system.

\subsection{MINE LOCOMOTIVE}

\subsubsection{Application Characteristics}

Mine locomotives are used to pull cargo carrying trailers through mines and tunnels. Their specific uses, duty patterns, expected life and overall economics vary among application classes, most significantly from coal mines to hard rock mines to tunneling operations.

Locomotives are used in coal mines primarily to provide tractor power for hauling workers and supplies. They see substantial use at the beginning and end of each shift. Since practically all underground coal mines haul coal out of the mine on belt conveyors, they see no duty during the middle of any given shift. Operation in such underground coal mines will typically be ten shifts per week. Thus, a locomotive here may expend as little as 30 full power-hour equivalents of energy per week or approximately 1600 fuel power hours per year. Life expectancy of a locomotive operating in the demanding conditions of an underground coal mine will typically be approximately three years.

Locomotives are used in hardrock mines to provide tractor power for hauling workers, supplies, and, in some mines, ore. In mines in which ore is hauled, the locomotive will see heavy duty throughout the work shift. If ore is hauled by conveyor, the duty pattern will be similar to that experienced in a coal mine. Hardrock mines will run up to 18 shifts per week, offering significantly better utilization of capital than coal mines. The environment in which the locomotive must operate in the hardrock mine is generally much less hostile than that seen in the coal mine; a typical lifetime for such a locomotive will be six to ten years.

Boring of tunnels for transportation facilities, aqueducts, and/or related to process construction such as power plants offers still better utilization of locomotives. They are typically used for providing tractive power to haul workers, supplies, and the rock removed from the tunneling surface. Contract tunneling operations may run up to 21 shifts per week. Equipment used in such operations tends to exhibit lifetimes comparable to those observed in hardrock mines. 
Two classes of systems are conventionally used for powering such locomotives:

- Lead acid batteries for locomotives with overall power requirements up to approximately $100 \mathrm{~kW}$; and

- Trolley wire systems for powering locomotives which require between 50 and $500 \mathrm{~kW}$ of electricity.

In addition, hybrid systems are marketed which include both battery and trolley wire power systems.

Most locomotives sold are battery powered. Trolley wire locomotives do account for a significant fraction of the locomotive power capacity sold, however, due to their higher individual ratings.

Neither battery nor trolley wire systems offer wholly attractive locomotive power. Disadvantages of the battery system include:

- The need to change the battery pack frequently. Such frequent changes require locomotives periodically to return to a recharging shed, thereby losing valuable work time.

- Battery cost. Standard practice calls for a mining company to buy two spare battery packs in addition to the basic battery pack included with the locomotive in order to minimize time lost due to lack of available charged batteries.

- Dead batteries. If this occurs during locomotive operation, it may result in individualized locomotives blocking tunnels.

Disadvantages of trolley wire systems include:

- Fires. Trolley wires are a major source of mine fires.

- Wire failure. General mining activities periodically result in severing of the trolley wires, with result in loss of power to the locomotives.

- Cost to install and maintain trolley wires. This is particularly important in a case such as tunneling where the principal point to be served by the trolley system is continuously moving at a fairly rapid pace.

In the size range of 50 to approximately $100 \mathrm{~kW}$, the choice between the battery locomotive and the trolley wire locomotive is primarily subjective, based on the judgment of the mining engineers involved. Since there appear not to be compelling economic arguments to drive this decision, the analysis of PAFC applications is based on comparison with the battery driven locomotive. 
For purposes of economic analysis, a locomotive will be considered which requires a power supply equivalent to $100 \mathrm{~kW}$ of unregulated DC. This corresponds to the most popular locomotive size, and provides a conservative scenario for evaluation of fuel cell systems for use in larger locomotives as well.

The application chosen for initial fuel cell locomotive evaluation is for tractive power in tunneling operations and the hardrock mines in which locomotives are used to haul ore to the surface. These applications were chosen because they offer high degrees of utilization. Locomotives are used many more hours per year, and at a higher load factor than in mines which use them solely to haul workers and supplies. They log annual energy expenditures of perhaps 2500 full power hour equivalents per year. Also in these applications the locomotive enjoys significantly greater life expectancy than it would in an underground coal mine.

An additional reason for choosing these applications over coal mining concerns energy economics. Tunneling operations and hardrock mining operations can occur anywhere in the United States. Electricity available in such mines will range from inexpensive coal or hydroelectric generated power to power generated in oil-fired power plants to power generated in small diesel generators at the job site. By contrast, at any location where a large underground coal mine is in operation, it can be expected that the supply of electricity will consist almost exclusively of inexpensive coal-based power.

It is expected that the fuel cell system will be required to carry ten full power hours equivalent of fuel on board. The battery driven locomotive will require use of a battery pack which will deliver five full power equivalent hours. As noted previously, two additional battery packs would be purchased with the locomotive. In this application, the locomotive could be expected to operate for approximately 5,000 hours per year, achieving a load factor averaging approximately $50 \%$ during operational periods.

Annual capital charges to be assessed to cover the cost of owning the locomotive power system will be calculated based on an assumed debt/ equity ratio of $30 / 70$. The real rate of interest on debt is assumed to be $3.5 \%$, while the real rate of return on equity is assumed to be $10 \%$. The locomotive is to be evaluated based on a book lifetime of eight years, corresponding to its expected useful physical life.

\section{5 .2 U.S. Market}

It is estimated that approximately 350 mine locomotives are sold each year with power requirements greater than or equal to approximately $100 \mathrm{~kW}$. Approximately $20 \%$ of these are sold to tunnel contractors; a small fraction are sold for use in hardrock mines where they will be used for hauling ore as well as personnel and supplies. For purposes of the analysis conducted here, it is assumed that the fraction of total sales which would find application where load factors and annual operating 
hours per year would approach the figures quoted in the preceding section would have an aggregate power requirement of $10 \mathrm{MW}$. This would be equivalent to 100 locomotive units with power requirements of $100 \mathrm{~kW}$ each to be sold per year. This market could be expected to persist through a locomotive useful life of eight years, during which time PAFC locomotives would displace battery locomotives. Subsequently, additional sales of new locomotives would be made to replace retired fuel cell locomotives. Thus, the constant PAFC locomotive population would be 800 units, each having $100 \mathrm{~kW}$ of generating capacity.

Operating 5,000 hours per year for eight years, a fuel cell powered locomotive would see 40,000 hours of operation during its lifetime. At the end of this time, the entire locomotive would be ready to be scrapped. This corresponds to expected useful life of the power section; no replacement power sections would be required.

\section{$\underline{6.5 .3 \quad \text { Capital Costs }}$}

Table 6.14 displays power system capital costs for the lead acid battery and for two competing fuel cell plant concepts: a $500 \mathrm{kPa}$ low power density fuel cell system based on methanol fuel, and a $500 \mathrm{kPa}$ high power density duel cell system based on methanol fuel. Note that the high power density fuel cell appears to offer lower capital costs than the battery system, even if accounted on a prototype basis. Both fuel cell systems offer lower capital costs if such costs are accounted based on an average for the first five years of production. Thus, it would appear that the PAFC mine locomotive power system is very nearly competitive with its conventional competition based on capital costs alone. As can be seen below, it offers additional economic advantages.

\subsubsection{Fuel/Energy Consumption}

Table 6.15 displays expected annual energy consumption of battery and fuel cell powered locomotives used in applications such as those described above. Due to the nature of the energy forms involved, this table is not directly comparable to those developed for other applications.

In the case of the battery system, the energy form used at the mine or tunnel es electricity. For this analysis, electricity is assumed to be purchased from the grid. Demand would be throughout the day, without regard for the timing of utility peak demand. It could be expected to contribute to the operations demand charge as well as to its energy charge. Accordingly, the electric power use must be based on energy plus demand.

Occurring throughout the day, this electric power requirement could be expected to increase energy use by the utility in the form of a time weighted average mix of its marginal fuel fired power generation modes throughout the day. This marginal generation form varies throughout 
TABLE 6.14

100KW MINE LOCOMOTIVE POWER SYSTEM CAPITAL COSTS, THOUSANDS OF 1982 DOLLARS

10 Fuel Power Hours Energy Storage*

Power System

Lead Acid Battery

$500 \mathrm{kPa}$ Low Power Density Fuel Cell Methanol Fue1

500 kPA High Power Density Fue1 Ce11 Methanol Fuel
Average Capital

Costs, One Year

of Production

297

323

275

234

Average Capital
Costs, Five Years
of Production

297

351

215

* Battery system consists of three 5-hour battery packs; one is recharged and another held on standby at a maintenance shed while the third powers the locomotive. 
TABLE 6.15

ANNUAL ENERGY/PETROLEUM CONSUMPTION PER MINE LOCOMOTIVE $\mathrm{G} J / Y R$

\begin{tabular}{|c|c|c|c|}
\hline Power System & $\begin{array}{l}\text { Lead Acid } \\
\text { Battery }\end{array}$ & $\begin{array}{l}\text { Low Power Density } \\
\text { Fuel Cel1, } \\
\text { Methanol Fuel } \\
\end{array}$ & $\begin{array}{l}\text { High Power Density } \\
\text { Fuel Cell, } \\
\text { Methanol Fuel }\end{array}$ \\
\hline $\begin{array}{l}\text { Energy Use at } \\
\text { Mine, Gj/Yr. } \\
\text { (Energy Form) }\end{array}$ & $\begin{array}{l}1200 \\
\text { (Electricity) }\end{array}$ & $\begin{array}{c}2140 \\
\text { (Methano1) }\end{array}$ & $\begin{array}{c}2350 \\
\text { (Methano1) }\end{array}$ \\
\hline $\begin{array}{l}\text { Near Term } \\
\text { Primary Energy } \\
\text { Use, Gj/Yr. } \\
\text { (Resource) }\end{array}$ & $\begin{array}{l}3690 \\
(50 \% \text { Coal, } \\
50 \% \text { Petroleum })\end{array}$ & $\begin{array}{c}3300 \\
\text { (Natural Gas) }\end{array}$ & $\begin{array}{r}3610 \\
\text { (Natural Gas) }\end{array}$ \\
\hline $\begin{array}{l}\text { Long Term } \\
\text { Primary Energy } \\
\text { Use, Gj/Yr. }\end{array}$ & 3640 & 3890 & 4270 \\
\hline
\end{tabular}


the country, but in most locations could be attributed in part to petroleum. Accordingly, for near-term analysis it is assumed that half of the electricity supplied for battery recharging is based on petroleum (that is, residual fuel oil by the steam plants) and $50 \%$ on coal. In the long run, it is assumed that all of this petroleum based generation is displaced by coal-fired generation.

The methanol-based fuel cell systems, of course, use more energy at the mine than the electricity-based battery system. A direct comparison of methanol use and electricity use is not appropriate; a more proper comparison can be made in terms of near-term and longterm primary energy use. In the near term, with methanol based on natural gas, it can be seen that primary energy use will be greater with the battery system than with the fuel cell system. This situation will reverse in the long run, when production of methanol from natural gas will be displaced by production of methanol from coal. Under these circumstances, coal-based electricity feeding a battery system will offer greater energy efficiency than coal-based methanol production to feed a fuel cell system.

\subsubsection{Life-Cycle Costs}

Tables 6.16 and 6.17 display annualized life-cycle costs of competing $100 \mathrm{~kW}$ mine locomotive power systems. The former compares with lead acid battery system with candidate fuel cell systems, based on average fuel cell capital costs from the first year of production. Capital charges are highest for the low power density fuel cell, followed by the battery, with the high power density fuel cell system being the lowest cost.

Fuel and energy costs are accounted based on methanol at $\$ 8 / G J$ as discussed in Chapter 3 , and electric power at $7 \mathrm{c} / \mathrm{kWh}$, based on an average of coal and oil fired power generation. Based on these energy prices, the fuel cell offers modest savings in energy costs. Comparative analysis of the same systems using parameters appropriate to a part of the United States where practically all power generation is based on coal (typical of many parts of the country where underground coal mining is conducted) would show fuel cost savings with the lead acid battery system compared to the fuel cell system. On the other hand, for operation at a remote site where electric power is generated using a diesel generator set, fuel cost savings would increase by an additional $\$ 23,000$ per year.

Operation and maintenance cost estimates include allowance for lower maintenance requirements for the fuel cell system and lesser labor and auxiliary equipment requirements for daily re-energizing of these systems. 
TABLE 6.16

COMPARATIVE ANNUALIZED LIFETCYCLE COST OF 1OOKW MINE LOCOMOTIVE POWER SYSTEMS

Thousands of 1982 Dollars, Based on PAFC Average Costs for the First Year of Production

\begin{tabular}{|c|c|c|c|}
\hline Power System & $\begin{array}{l}\text { Lead Acid } \\
\text { Battery }\end{array}$ & $\begin{array}{l}\text { 50C. kPa Low Power } \\
\text { Density Fue1 Ce11, } \\
\text { Methanol Fue1 }\end{array}$ & $\begin{array}{l}500 \mathrm{kPa} \text { High Power } \\
\text { Density Fuel Cel1, } \\
\text { Methanol Fuel }\end{array}$ \\
\hline Capital Charges & 54 & 59 & 39 \\
\hline $\begin{array}{l}\text { Fue1/Energy } \\
\text { Costs* }\end{array}$ & 23 & 17 & 19 \\
\hline $\begin{array}{l}\text { Operation and } \\
\text { Maintenance Costs }\end{array}$ & 35 & 25 & 25 \\
\hline Total Annual Costs & 112 & 101 & 83 \\
\hline
\end{tabular}


TABLE 6.17

COMPARATIVE ANNUALIZED LIFE-CYCLE COSTS OF

100KW MINE LOCOMOTIVE POWER SYSTEMS

Thousands of 1982 Dollars, Based on PAFC Average Costs for the First Five Years of Production

\begin{tabular}{|c|c|c|c|}
\hline Power System & $\begin{array}{l}\text { Lead Acid } \\
\text { Battery }\end{array}$ & $\begin{array}{l}500 \mathrm{kPa} \text { Low Power } \\
\text { Density Fuel Cel1, } \\
\text { Methanol Fuel }\end{array}$ & $\begin{array}{l}500 \mathrm{kPa} \text { High Power } \\
\text { Density Fuel Cel1, } \\
\text { Methanol Fuel }\end{array}$ \\
\hline Capital Charges & 54 & 50 & 33 \\
\hline \multicolumn{4}{|l|}{ Fuel/Energy } \\
\hline Costs* & 23 & 17 & 19 \\
\hline \multicolumn{4}{|l|}{ Operation and } \\
\hline Maintenance Costs & 35 & 25 & 25 \\
\hline Total Annual Costs & 112 & 92 & 77 \\
\hline
\end{tabular}


These effects taken together result in total annual cost savings of $\$ 11,000-29,000$ for the fuel cell system. Such cost savings are quite substantial, particularly for a system accounted based on a national average marginal electric power cost for battery recharge and average fuel cell system capital costs for the first year of production. Table 6.20 displays still greater potential savings using the fuel cell if its capital costs are accounted based on average figures for the first five years of production.

\subsubsection{National Energy/Petroleum Savings}

As noted previously, the fuel cell offers savings over the batterybased mine locomotive power system only under certain circumstances. Based on a national fuel cell locomotive population of 800 units (the steady state population predicted in Section 6.5 .2 above), national energy and petroleum savings predictions are shown in Table 6.18.

of course, more energy is used at the mine with the fuel cell system than with the battery system, since the battery uses electricity purchased from the grid, while the fuel cell starts with a portable liquid fuel. Evaluation in terms of use of primary resources, a more appropriate comparative evaluation, shows some savings attributable to the fuel cell in the near term. More importantly, significant savings in petroleum may be afforded in the near term. In the long term, with all electricity and methanol allowed produced from coa1, PAFC offers less energy efficiency than the battery system. This is not surprising, given the substantial energy loss involved in producing the methanol from coal. This 1 oss of $45 \%$ of the coal's energy value cannot be offset with the efficiency with which the fuel cell uses the resulting methanol.

\section{5 .7 Export Market}

It is estimated that the export market for high duty mine locomotives such as might be served with fuel cell based locomotives is approximately six times the size of the U.S. market. The size of this market is due in part to the comparatively greater use of locomotives and lesser use of belt conveyors for hauling product out of mines elsewhere in the world.

\subsubsection{Circumstances for PAFC Viability}

\subsubsection{Developments Which Favor Economics}

Two unrelated developments contribute significantly to the economic attractiveness of the fuel cell power system for the locomotive. The first is availability of methanol as a fuel at prices roughly equivalent to those of petroleum based fuels. It is this availability of methanol at competitive prices which will afford modest fuel cost savings for the fuel cell systems in the near term. 
TABLE 6.18

NATIONAL ENERGY/PETROLELI SAVINGS-MINE LOCOMOTIVES

SAVINGS USING PAFC COMPARED TO LEAD ACID BATTERY

$\mathrm{TJ} / \mathrm{YR}$

\section{Power System}

Energy Savings at the Mine

Near Term Primary

Resource Savings*

Near Term Petroleum

Savings*

Long Term Primary

Resource Savings:*
Low Power Density

Fuel Cell

( 750)

310

1480

$(200)$
High Power Density Fuel Cell

(920)

60

1480

$(500)$

* Near term basis of methanol production is natural gas. Near term basis of marginal electric power production is $50 \%$ coal, $50 \%$ residual fuel oil.

**Long term basis of production of methanol and of marginal electricity is coal. Since both are based on coal, PAFC offers no comparative petroieum savings. 
The second development is capital cost reduction for fuel cell systems as a result of learning curve effects. This is important for establishing the magnitude of cost savings associated with the fuel cell. However, it is expected that significant numbers of locomotives could be sold for very high duty uses and/or for use at sites which must generate their own power at current fuel cell prototype costs.

Review of Tables 6.16 and 6.17 indicates that the fuel cells appear to offer savings compared to battery systems in nearly every cost category. This is in sharp contrast, for example, to the railroad locomotive application, in which the fuel cell suffers significant disadvantages in capital cost and operation and maintenance costs, which it has to make up in fuel savings. This pattern of modest savings in each cost account renders the conclusion that the fuel cell is the preferred mine locomotive system far more credible, since it is much less sensitive to assumptions concerning the relative importance of the various basic cost accounts. For example, operation and maintenance costs of the battery system will be significantly greater than those of the fuel cell system. Exactly how much greater cannot be predicted at this time. However, since this differential is not required to offset directly a cost advantage enjoyed by the battery in another cost category, exact prediction is not required. Similarly, if a significant capital cost advantage were enjoyed by the battery, variations in the expected rate of return on equity and the associated capital charge rates (rates which legitimately vary among mining companies) could change the basic conclusions.

Finally, it should be noted that the fuel cell probably enjoys additional advantages in allowing higher utilization of the locomotive. These advantages are not quantified here. Inclusion of capital investment for three battery packs in the battery locomotive and an operation and maintenance cost differential at $\$ 10,000$ per year between the two systems is believed to account for the direct cost of owning and operating a battery driver system which will have most of the utility of the fuel cell system. This would include operation with minimum practical loss of useful locomotive work time to return to the maintenance shed for battery changes, and minimization of locomotive failures in operation due to dead batteries. Nevertheless, it must be expected that some loss of work time and/or dead battery events will result in lost effective locomotive operation, and possibly lost production. The proper way to account this might be to consider the relative number of useful working hours offered by each locomotive system, analogous to the useful bottom hours accounted to the various submersible systems considered in the following section. Data is not available, however, so the analysis must end with the conclusion that the fuel cell appears to be economically preferable to the battery based on a simplified analysis, and that investigation of the application in detail could be expected to increase the savings associated with the fuel cell system. 


\subsubsection{Requirements for Technical Viability}

Two developments must occur in order to establish the technical viability of the fuel cell powered mine locomotive. The first is that an approach must be developed toward fuel cell power system idling which can be sustained for thousands of hours per year and which will not result in aging of the stack. This problem is analogous to that discussed with the railroad locomotive.

The second development required is of a regulatory nature. For the PAFC to be viable, it must be permitted to use methanol in mines and tunnels. Whether or not this volatile, combustible, and toxic material will be acceptable in such an environment cannot be predicted.

\subsection{ROBOTIC SUBMERSIBLE POWER}

\subsubsection{Application Characteristics}

It is proposed here to use a phosphoric acid fuel cell to power a small robotic submersible. Such a submersible would be used for gathering date (in particular, for videotaping underwater structures) and possibly to perform simple tasks under water.

Such a robotic submersible is not in commercial use today. Rather, it is considered to be the next logical development in submersible technology. Today, the dominant system being deployed is an unmanned submersible which is tethered to a mother ship. The mother ship provides electricity to the submersible and controls its operation via the tethering cable. In this way, submersible operation is actually directed by a mother ship crew member, who sits at a control panel on the ship monitoring submersible operation via closedcircuit television.

This tethered submersible has developed from older, manned submersibles, which cruised more or less independently of their mother ships. They performed both data gathering and working tasks under water. Their limitation was mission length, being limited to approximately eight hours under water by power system and crew performance considerations. By contrast, the tethered submersibles are frequently put in the water for 48 hours at a time.

A wholly robotic submersible might also be built for operation for 48 hour periods in the water. It would be capable of directing its own movement as it videotaped underwater structures, by cruising along a pipeline, moving up and down the supports of an off-shore production platform, etc. It would be designed to operate in the water for continuous periods up to 48 hours, as is now common with tethered submersibles. It would have the fundamental advantage over tethered submersibles that the mother ship need not be continually present. It would have other advantages, such as decreasing the crew requirements for directing the submersible, decreased capital cost for the tether 
system, etc. The only disadvantage foreseen vis-a-vis a tethered submersible would be that it would likely be relatively limited in the types of tasks which it could perform, limited by its own onboard artificial intelligence.

Any of these submersible systems might be expected to be at sea, either working or waiting for favorable weather for approximately 200 days per year. This figure is considered to be limited by logistics of deployment and use, but not by the demand for the services of the submersible.

If the technology existed today to build the robotic submersible, the power supply of choice almost certain1y would be conventional lead acid batteries. For purposes of this analysis, it is expected that such a submersible would require 864 kilowatt hours of battery storage capacity, or the equivalent of an average $18 \mathrm{~kW}$ of electric power over a period of 48 hours.

It is proposed to substitute a hybrid phosphoric acid fuel cell plus battery system for this all-battery system. A $20 \mathrm{~kW}$ PAFC

system would be used, together with a very limited amount of shortterm battery storage capability, to serve submersible peak demands. The PAFC system would operate at $500 \mathrm{kPa}$, using hydrogen as fuel and oxygen as oxidant. Hydrogen would be carried on board the submersible stored as a metal hydride. Oxygen would be carried on board stored as compressed gas.

Submersibles typically are bought and used by small firms engaging in underwater work for the major oil companies on a contracted basis. As such, their financing is a very complex undertaking. It is based primarily on a loan from a financial institution, which uses the projected cash flow from underwater work based on terms of existing contracts for such work as the basis for determining credit-worthiness. Furthermore, this institution would require that a costly insurance policy be taken out on the submersible, naming the financial institution as beneficiary. As a proxy for this very complex financing, economics of the submersible are evaluated here as they might appear if the system were to be owned and operated by a large, financially strong company. It is evaluated based on 100 percent equity financing, with a 10 percent real rate of return on equity. Payback periods for investments in submersibles range from one to five years. This range was chosen because:

- A payback period of one year may be required in some contracted underwater work, to coincide with the period of the contract.

- A lifetime of five years is approximately equivalent to the physical life expectancy of a submersible. It may also be longer than the system's economically useful life, as further development renders existing models obsolete. 


\subsubsection{U.S. and Export Markets}

Available data shows no difference between a U.S. market and an export market. Submersibles tend to be used off-shore throughout the world by the same small set of companies, mostly owned by or doing contracted work for large multi-national corporations. For this reason, the entire analysis conducted here will be based on sale of submersibles on the world market.

It is estimated that approximately 25 robotic submersibles might be built and sold per year. This is based on the estimate that approximately 50 tethered submersibles are being built and sold per year today, and the expectation that a robotic submersible could do many tasks more effectively than a tethered submersible, but would be unable to do some things that a tethered submersible can do. Thus, it could be expected to capture only a fraction of the market held today by tethered submersibles.

\subsubsection{Capital Costs} systems :

Capital costs are projected for three alternate submersible power

- A system based entirely on lead acid batteries;

- A system based on a $500 \mathrm{kPa}$ low power density fuel cell;

- A system based on a $500 \mathrm{kPa}$ high power density fuel cell.

Capital costs for these systems are shown for mission lengths of eight hours and 48 hours in Table 6.19. These capital costs are quoted on a prototype basis only; this market is so small that no significant learning curve effects could be expected to be associated with it. If no other commercial applications develop to bring about such learning curve related cost reductions, then fuel cells for use in submersibles would have to compete at prototype costs.

The figures quoted in Table 6.19 include the total capital investment associated with the submersible power system. They do not include the cost of the balance of the submersible or the cost of the mother ship. As will be seen below, the fuel cell offers solid economic advantage, but based on its overall better utility rather than on lower capital costs. In order to evaluate this advantage, it is necessary to include allowance for all factors in the evaluation of life-cycle costs, ultimately comparing costs incurred per hour of useful work time. In this respect, analysis of fuel cell use in the submersible (and in the mine locomotive) is fundamentally different from the analysis of Arctic village power and railroad locomotive system. In the submersible, the fuel cell can be credited with the cost savings effected elsewhere in the overall system; in village power and railroad locomotives, the fuel cell substitutes for a system which offers essentially the same utility. 
TABLE 6.19

20KW EQUIVALENT SUBMERSIBLE POWER SYSTEM CAPITAL COSTS

Thousands of 1982 Dollars

Mission Length,

Full Power Equivalent Hours

8

Power Systems

I. Fuel Ce11, $500 \mathrm{kPa}$ Low Power

Density in Service Cell

87

139

Hydride $\mathrm{H}_{2}$ on Mother

Ship, Storage, Liquid $\mathrm{O}_{2}$

Storage

$\underline{24}$

$\underline{76}$

Total

111

215

II. Fuel Cell, $500 \mathrm{kPa}$ High Power

Density in Service Cell

Hydride $\mathrm{H}_{2}$ on Mother

Ship, Storage, Liquid $\mathrm{O}_{2}$

Storage

26

83

Tota1

84

199

III. Lead Acid Battery,

In Service

On Mother Ship

47

$\underline{186}$

Total

79

357 


\subsubsection{Fuel Consumption}

Estimation of annual fuel consumption requires consideration of the makeup of a "typical" mission. A typical mission is considered to have a total length equal to the time from the beginning of the submersible's dive to the beginning of the submersible's next dive, assuming that the submersible returns to the mother ship for service but is sent out again as soon as possible. The return of the submersible from the work point to the ship, its servicing, and its return to its work point collectively are estimated to require a period of $1-1 / 2$ hours for a fuel cell based system, and 2 hours for a battery based system. In both cases, this assumes that dive and cruise to the work point require approximately $1 / 2$ hour, and surfacing and rendezvous with the mother ship require approximately $1 / 2$ hour. Refueling a fuel cell based system requires $1 / 2$ hour, while replacement of the battery pack for a battery based system requires one full hour. This difference results because the fuel cell can be refueled while the submersible is in the water, while battery pack substitution must be accomplished aboard the mother ship. Thus, in a given eight hour mission, a battery-based submersible could be expected to spend six useful hours working on the bottom. A fuel cell power system designed for an eight hour mission would be able to spend $6-1 / 2$ hours usefully working on the bottom per mission. A fuel cell system designed for a 48 hour mission (not possible with batteries) length would be able to spend 46-1/2 hours working on the bottom per mission. Put another way, in a 24 hour day, the battery-based, eighthour mission submersible could do 18 hours of useful bottom work, the comparable fuel cell-powered submersible could do 19-1/2 useful bottom hours of work, and the 48 hour mission length fuel cell powered submersible could do $23-1 / 4$ useful bottom hours of work.

Table 6.20 presents annual energy consumption for such submersibles. It is accounted on the basis of energy use on the mother ship to generate electricity to charge batteries or hydrogen to fuel the fuel ce11. Also accounted are the attendant near-term and long-term primary energy usages of the competing submersible systems. These figures are based on diving 200 days per year, maximum credible number. If logistics and/or weather limit driving to fewer days per year, energy use will decrease accordingly. As will be seen, such lower utilization would not seriously reduce PAFC's basic economic advantage.

Not accounted here is energy used by the mother ship. It is expected that this will dwarf energy use by the submersible itself and will significanlty increase savings accountable to the submersible when considered in terms of energy expenditure per useful working bottom hour of submersible time. 


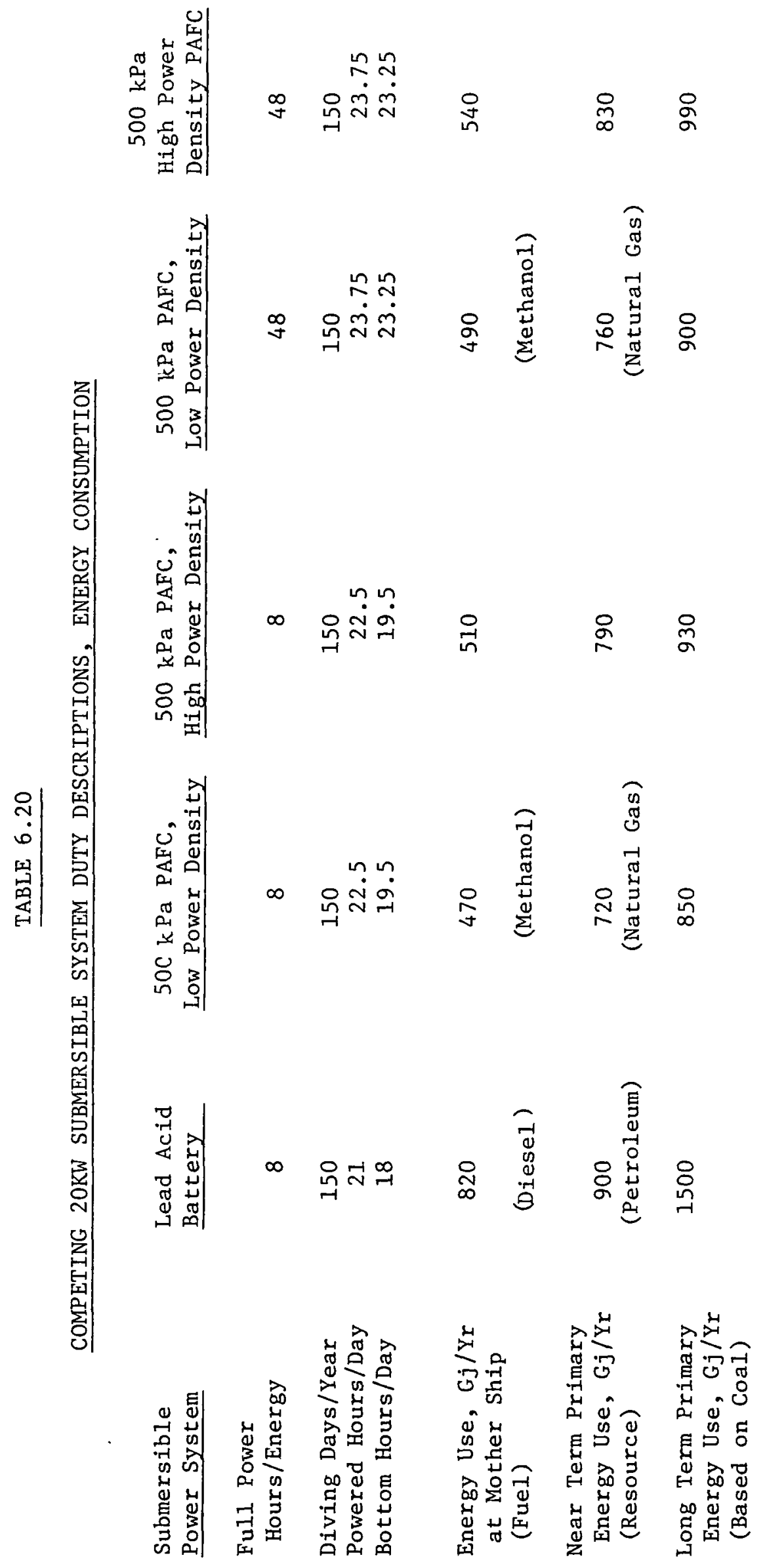




\subsubsection{Life-Cycle Costs}

Table 6.21 presents an estimate of the total cost to own and operate a submersible for 200 working days during the year. This table accounts full capital costs of systems whose omission was previously noted: spare batteries, shipboard hydride hydrogen storage, etc. It also accounts operation and maintenance costs and allows computation of the total cost of deploying and operating a submersible per useful bottom hour of work accomplished by that submersible.

The competing systems considered here are the eight hour mission length battery system, the eight hour mission length low and high power density fuel cell systems, and the 48 hour mission length low and high power density fuel cell systems. A 48 hour mission length battery system was not considered because of its prohibitively high capital cost (much higher than the fuel cell system when consideration is given to the need for a second battery pack to be recharged during submersible operation) and because such a system would be impractically heavy, exceeding that of PAFC by approximately 9 tons (compared to a submersible weight without power system of approximately 10 tons). Weight is a key consideration in choosing a power system because the greater the lift capability required, the greater the rental rate for the mother ship.

A spare battery pack must be available on the ship and recharged while the submersible is in operation. A submersible will rendezvous with the mother ship, have its largely spent battery pack removed and a fresh fully charged battery pack placed on board. During the submersible's next eight hour mission, the depleted battery pack will be recharged. Mother ships servicing fuel cell based submersibles must have on board the capability to store hydrogen generated from methanol. An on board hydride/hydrogen storage system and equipment for storing compressed oxygen are included, both for 8 hour and 48 hour mission length fuel cell systems. The balance of the cost of the submersible is estimated at $\$ 218,000$ based on the figure of $\$ 250,000$ for submersible with one battery pack. This is fairly common for equipment to be placed in the water today. The magnitude of this number would, of course, vary with the cost of the robotic control system and the variety of tasks which the submersible has to be built to perform.

Annual costs include an operation and maintenance allowance which are conservatively estimated to be the same for all submersible systems considered here. In reality, it is likely that it would be higher for the battery based system.

The cost of energy for the submersible is simply the cost of direct fuel used on the mother ship to generate electricity to charge batteries for the battery system (using a diesel engine generator) or methanol used to generate hydrogen for the PAFC system. It is the 


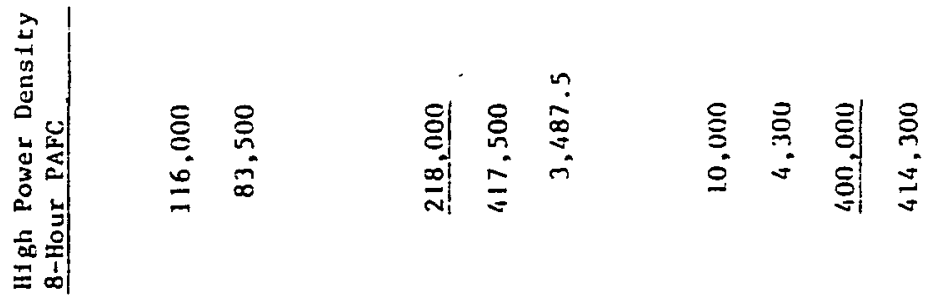

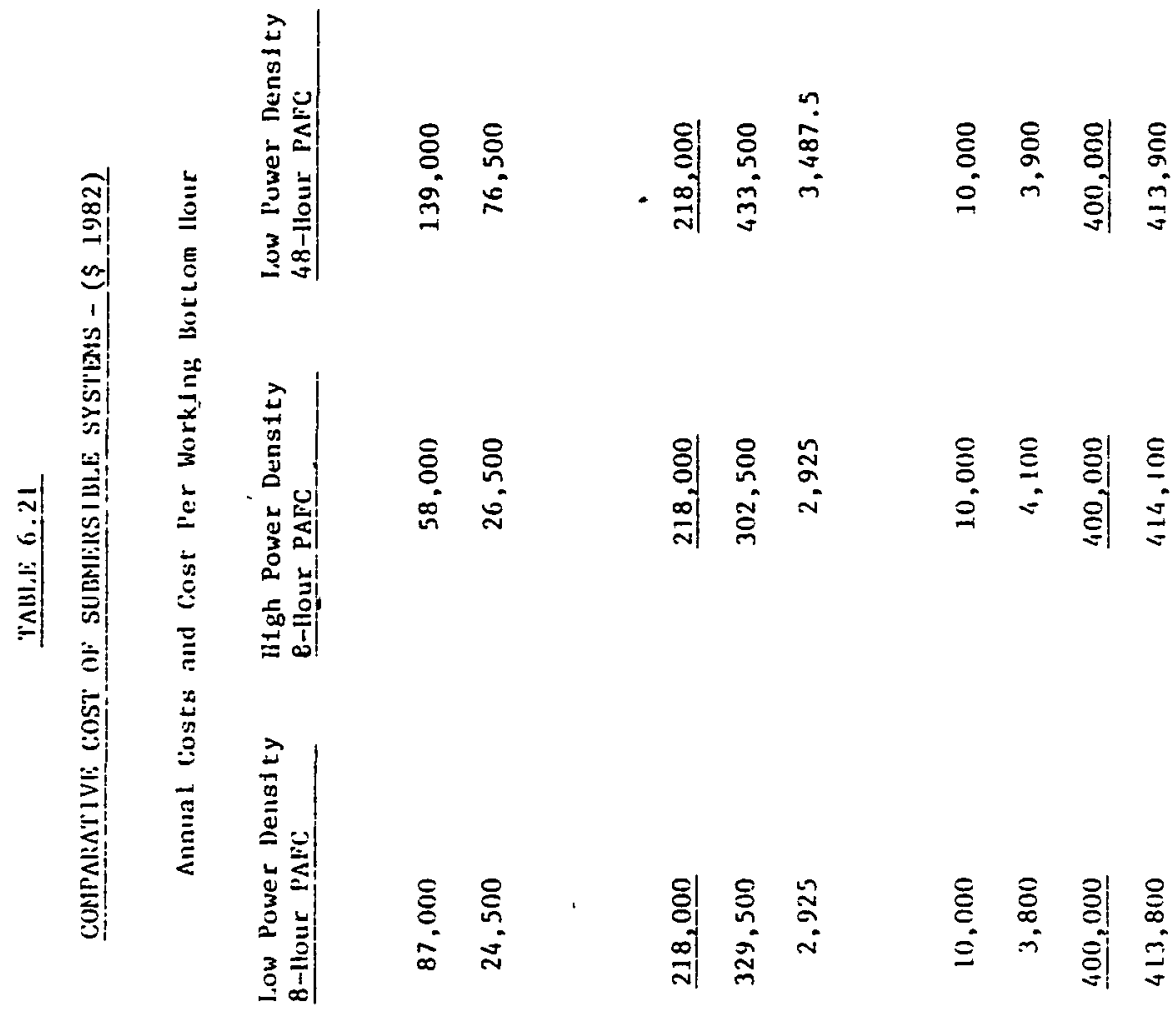

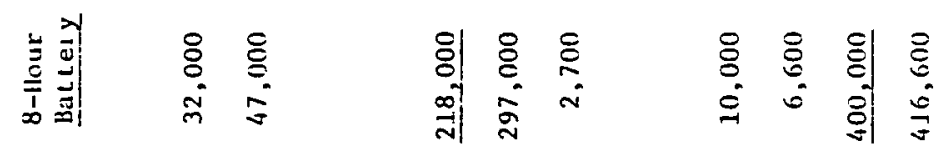

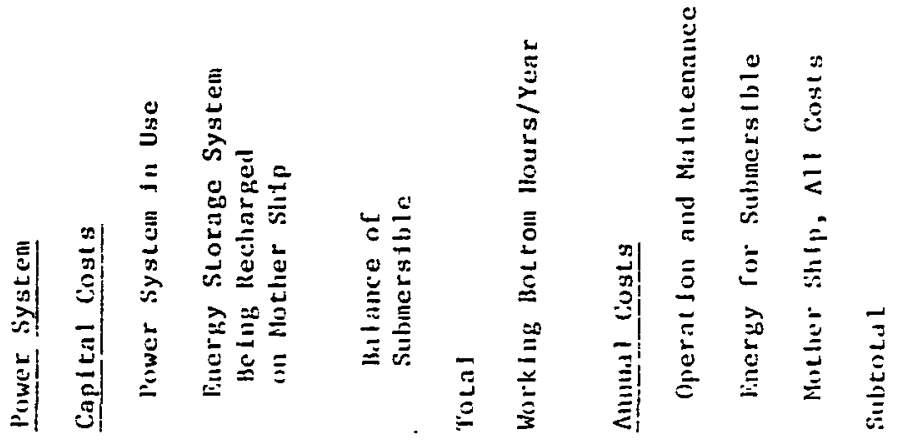




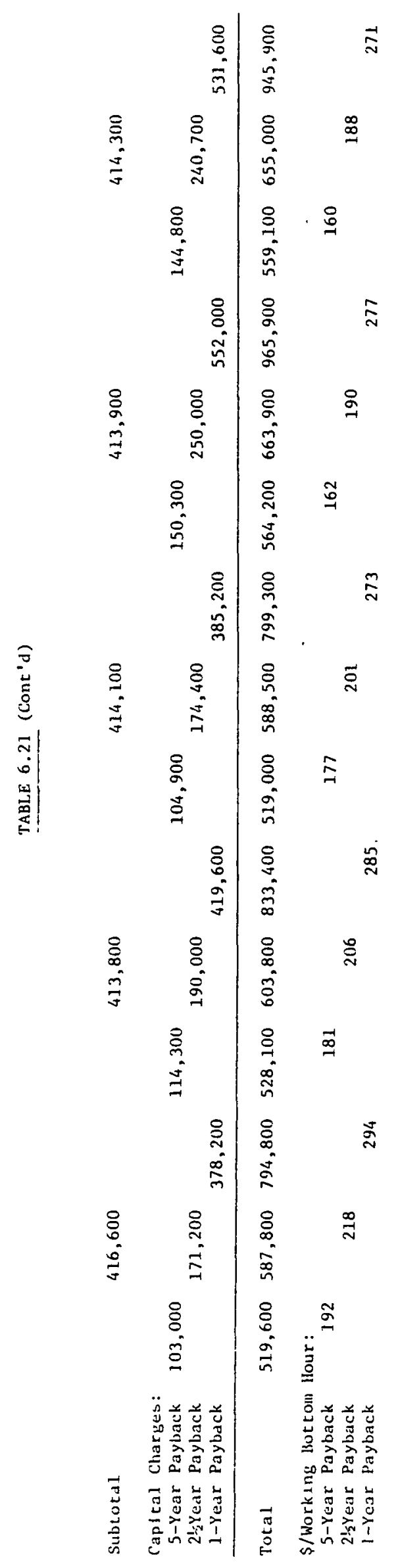


only cost listed which is directly related to submersible diving hours. A reduction in submersible utilization due to poor weather or logistical problems posed by operation far from port would directly reduce this expenditure. As can be seen, these costs are very small, and charges in submersible energy consumption cannot be expected to impact total annual costs significantly.

The charge for the mother ship is based on a typical figure for renting such a ship of $\$ 2,000$ per day, including crew, fuel, etc. for 200 days per year. This daily rate is somewhat variable, depending upon the full capabilities of the ship hired. As noted previously the gross tonnage life capability of the mother ship is of particular importance. This suggests use of the lighter fuel cell based systems in preference to the battery based systems. Thus, accounting of one rental rate for all mother ships is probably conservative, a higher rent may be required for the mother ship which will service the battery powered submersible.

Total annual costs are accounted for each submersible system based on three different payback periods. As noted previously, these range from one year (typical of underwater work contract terms) to five years (an approximate expected life of such a submersible).

Useful working bottom hours are estimated based on diving 150 days per year. This number is smaller than the number of days per year for which the mother ship is rented for reasons:

- Logistics of operation, especially if far from port, will require that significant time be spent taking on supplies and cruising to and from job sites.

- Bad weather at the job site will prevent submersible operation some of the time.

This number is of little significance for the economic comparison, since only the submersible energy consumption is directly related to it. The operating time estimate of critical importance in the economic evaluation, 200 days per year of mother ship rental required, is considered to be a moderate figure for submersible support operations.

For each case, it is possible to compute a cost per working bottom hour by dividing total annual cost by the expected annual working bottom hours. As can be seen, for each payback period, each fuel cell system appears to be more economical than the eight hour battery system. The 48 hour mission length fuel cell systems appear to be more economical than the eight hour mission length fuel cell systems, and the high power density fuel cell systems appear to be more economical than the low power density fuel cell systems. 


\subsubsection{Nationa1 Energy/Petroleum Savings}

No estimate is offered for these savings for two reasons:

- True energy savings will be dominated by savings on use of fuel by the mother ship, particularly as use of long mission length robotic submersibles allows one mother ship to perform a variety of tasks while at sea, possibly, including tending other submersibles.

- Operations utilizing these submersibles are conducted off-shore; it may, therefore, be difficult to distinguish between energy savings attributable in the U.S. and those attributable elsewhere.

In any case, such energy savings will be very minor on the scale of energy use in the United States. This market is simply too sma11 and accounts for systems which use too little energy to be of any consequence whatsoever for overall energy use in the United States.

\subsubsection{Circumstances for PAFC Viability}

\subsubsection{Developments Which Favor Economics}

Based on the foregoing analysis, it would appear as if the phosphoric acid fuel cell would be an economical approach for powering a robotic submersible, even at prototype cost. No further capital cost reduction appears to be required in order to make PAFC economically attractive. To be sure, reductions in capital cost would enhance the attractiveness of PAFC, but the savings resulting from the improved utility of operation will be of paramount importance.

\subsubsection{Requirements for Technical Viability}

The single most important development required to establish the viability of the fuel cell power submersible concept envisioned here will be full development of the balance of the robotic submersible exclusive of the power system. The phosphoric acid fuel cell makes possible mission length which could utilize such a robotic submersible much more thoroughly than would be possible with batteries. In this respect, the existence of the fuel cell encourages the development of the rest of the submersible technology.

Incremental $R \& D$ would be required to develop a phosphoric acid fuel system to operate at high pressures on hydrogen and oxygen received from hydride and pressurized gas storage. This would almost certainly require minor effort, focusing on patterns of waste heat evolution unique to such a system, on integration with the hydride/ hydrogen energy storage system, on condensation and exhaust of liquid water, and on general construction of the PAFC system to operate in a forgiving fashion in a relatively hostile environment. 


\section{REFERENCES}

A. F. J. Andress, "The Learning Curve as a Production Tool", Harvard Business Review, Volume 32, January-February, 1954, pp. 87-97.

B. W. B. Hirschman, "Profits from the Learning Curve", Harvard Business Review, Volume 42, January-February, 1964, pp. 125-39.

C. FUTURE FUELS AND ENGINES FOR RAILROAD LOCOMOTIVES, VOlume II. Stallkamp, J. A. (Jet Propulsion Lab., Pasadena, Ca. (USA)). November 1981. 413p. 


\section{APPENDIX A}

PHOSPHORIC ACID FUEL CELL AND CONVENTIONAL SYSTEM DATA BASE

\section{A.1 ENERGY SYSTEM MODULE DATA}

Table A.1 presents data describing the weight, volume, cost, and efficiency of all energy system modules which were modeled for general consideration in this study. Additional information on characteristics of these modules may be found in Chapter 3 .

Two classes of modules are shown in Table A.1:

- Energy storage systems

- Energy conversion systems.

The weight, volume, and cost of energy storage systems is calculated as a function of the energy stored, expressed in gigajoules in the form:

$$
a(\text { gigajoules })^{b}
$$

The weight, volume, and cost of energy conversion systems is calculated based on the energy output capability of the individual module, expressed in kilowatts, in the form:

$$
a(\text { kilowatts })^{b}
$$

Each module's efficiency is calculated based on system output, in the form:

$$
x+y(k i l o w a t t s)
$$

Note that al1 storage systems are $100 \%$ efficient. Exact definitions of module scope, energy input, energy output, and efficiency are often complex; see Chapter 3 for details.

\section{A.2 CHARACTERIZATION OF A COMPLETE POWER SYSTEM}

The data shown in Table A.1 is used to calculate weight, volume, cost and efficiency of complete power systems. This data should be used according to the following procedure:

- Specify the modules which will constitute the power system. Based on information contained in Table A.1 concerning which modules can receive feed from and provide feed to which other modules, determine whether the contemplated system configuration is physically feasible.

- Specify system power output and required equivalent full power hours of energy storage capability. 


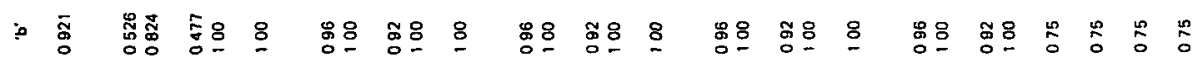

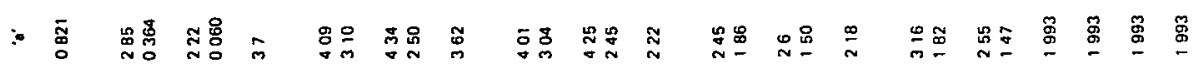

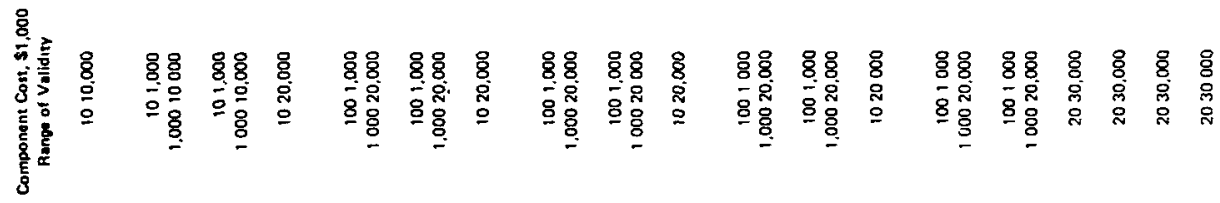

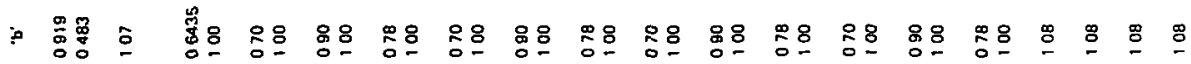

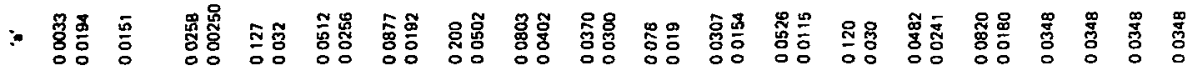

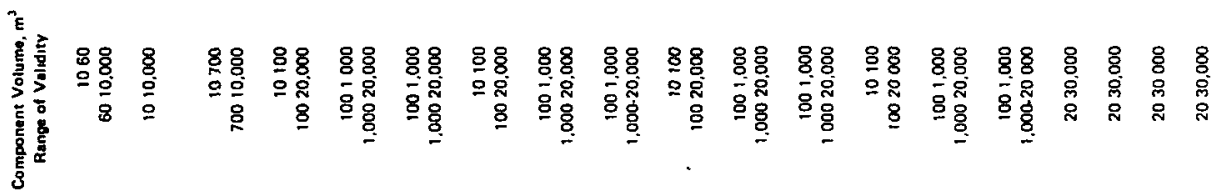

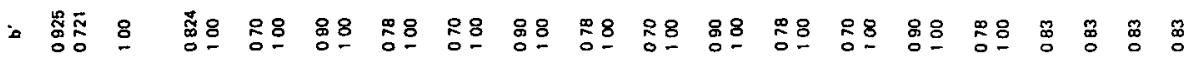

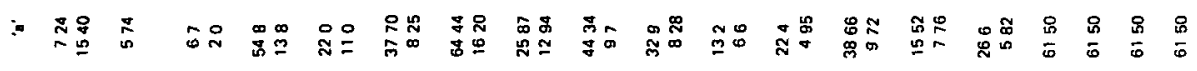

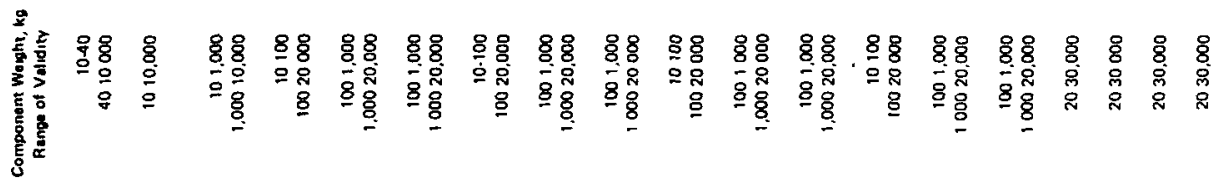

安|

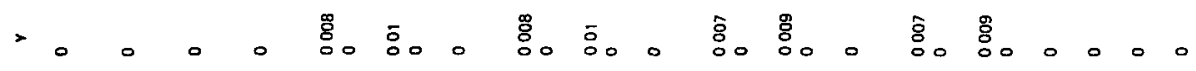

× ๙

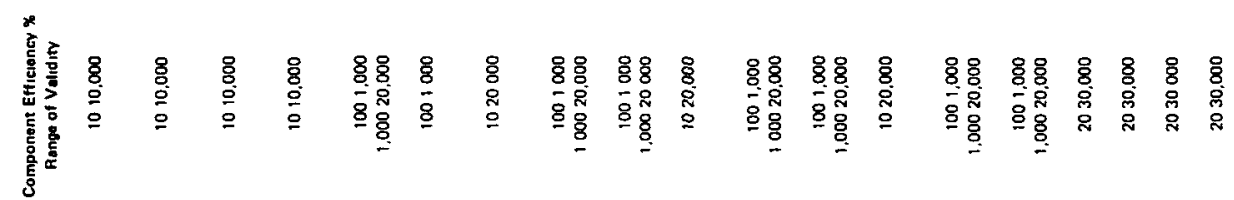

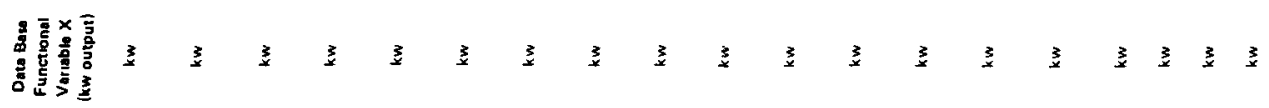

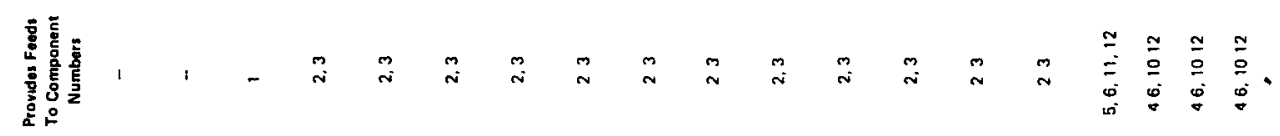

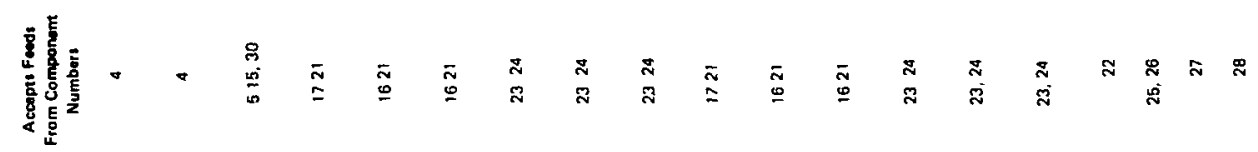

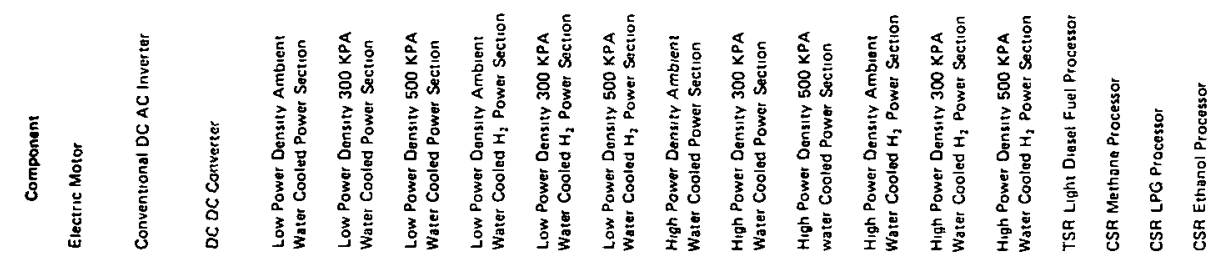
旁旁旁 A-2 
$\therefore$ 응

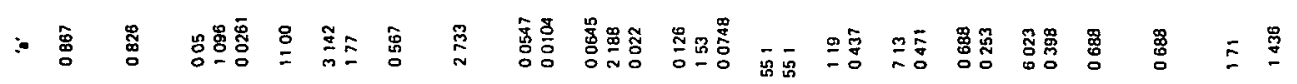

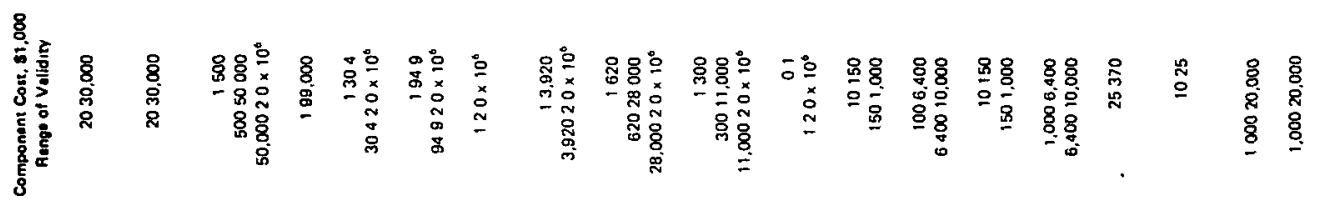

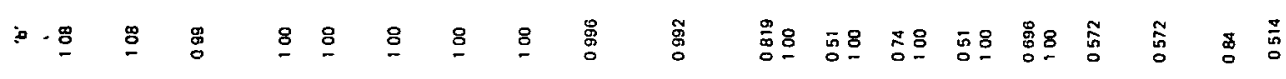

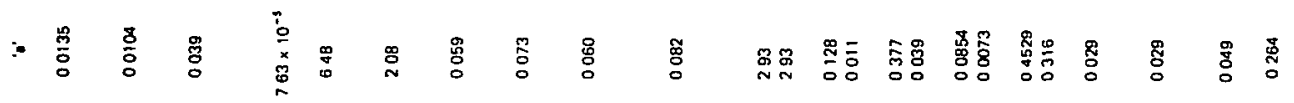

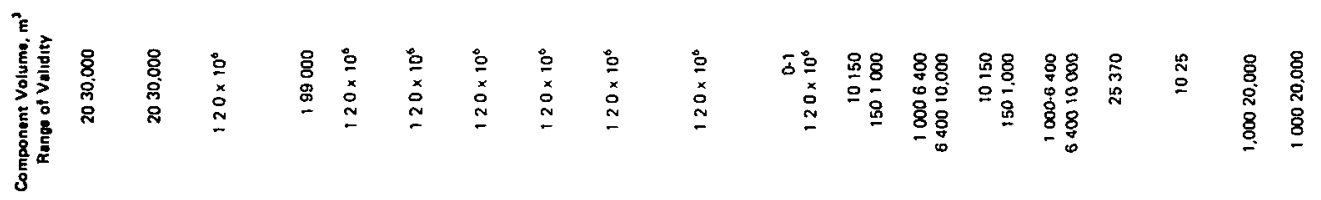

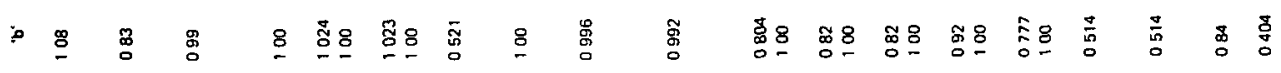

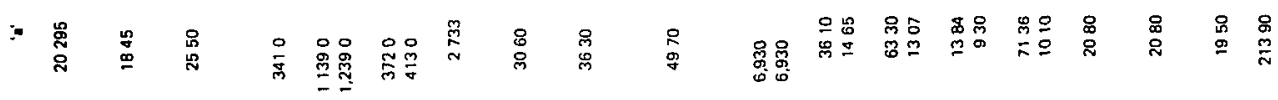

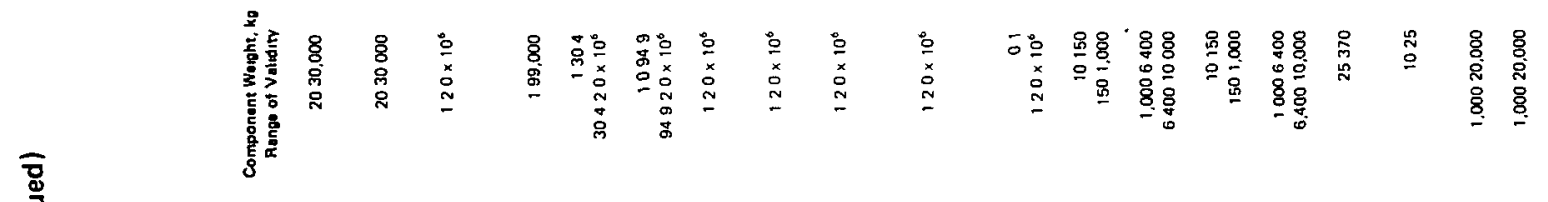

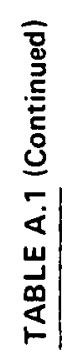

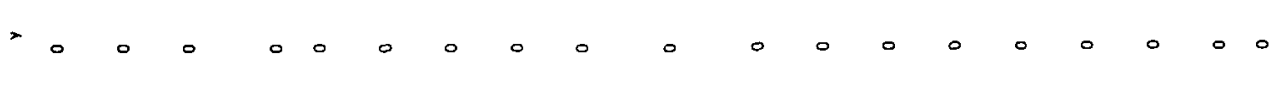

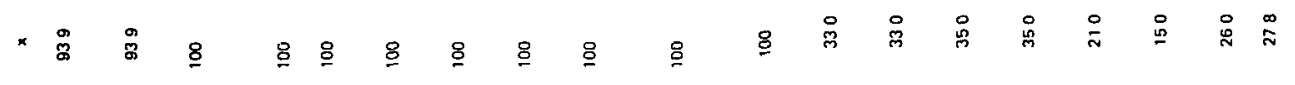

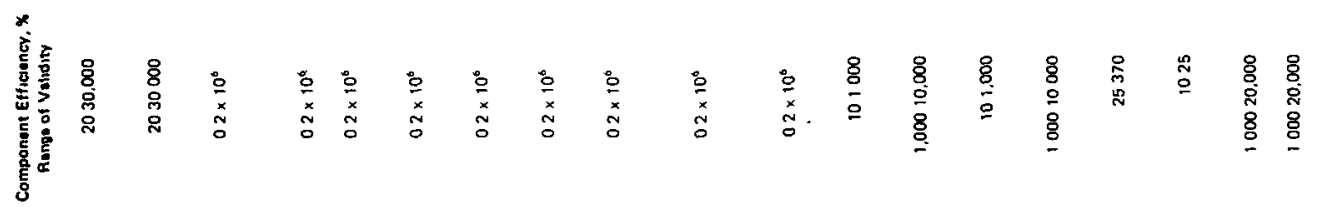

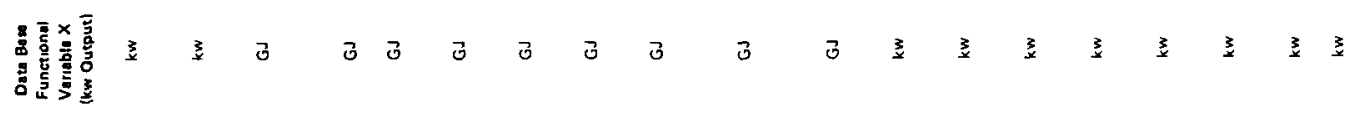

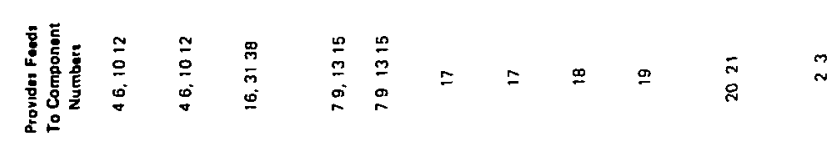

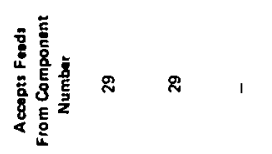

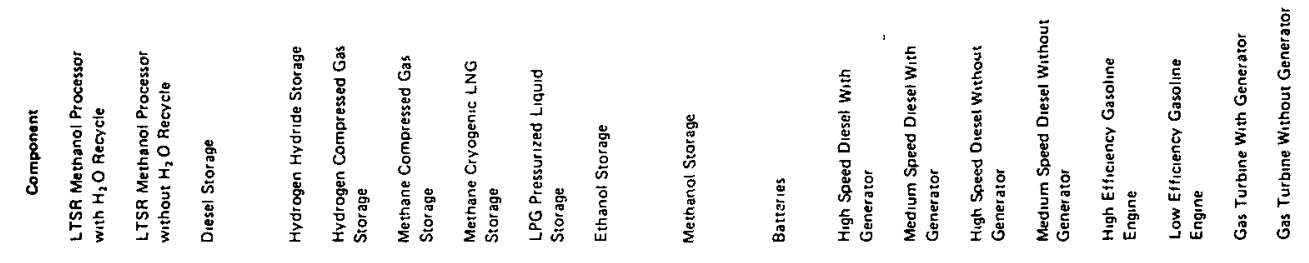

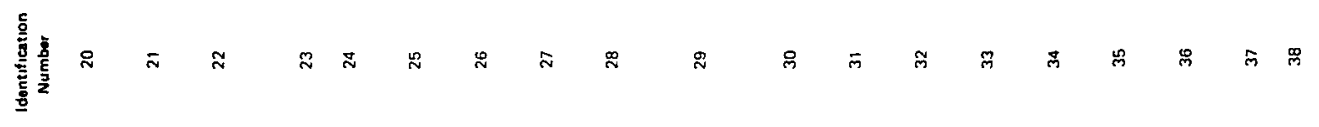


- Begin with the power-output module. Based on its rate of power output expressed in kilowatts, calculate the weight, volume, and cost of this component.

- Divide the power-output of the output module by the output module's efficiency to yield the rate of energy input required to this module. This rate of energy input will equal the energy output of the module which feeds the system output module.

- Take this energy output rate for the module which feeds the system output module to calculate its weight, volume, and cost.

- In this way, work backward through the system, calculating each module's weight, volume, and cost based on its rate of energy output, then calculate its rate of energy input which will serve as the basis for characterizing the next upstream module. Continue with this procedure until reaching the fule storage module.

- The above-described evaluation of the power system will specify an energy output rate required from the energy storage system, in kilowatts, as needed to feed the fuel processor of hydrocarbon- or alcohol-based systems, or to feed the power section in hydrogen-fuel systems. This together with required full power hours equivalent of energy storage capability will allow estimation of total energy storage capability, in gigajoules. Using this information, the weight, volume, and cost of the energy storage system is calculated, for addition to the weight, volume, and cost of all heretofore characterized modules in the system. This will provide total system weight, volume, and cost.

- Multiply efficiencies of all modules in the system together to yield a total system efficiency. Note that efficiencies of some power section modules are themselves functions of module output. As with other power section characteristics, they must be calculated based on that module output, not on system output.

As an example, consider the system characterized in Table A.2. Each module's weight, volume, and cost is calculated based on its output, using data given in Table A.l. Output of each module is calculated based on the output of the preceding module and the efficiency of the preceding module. In this fashion, calculation is conducted backward through the system from the power processor to fuel storage. System weights, volumes, and costs are then totaled for the individual figures determined for individual modules. Likewise, the overall system efficiency is the product of the individual module efficiencies. 
TABLE A. 2

EXAMPLE SYSTEM CALCULATION

\section{1,000 KW AC Methanol Fueled Power Plant Eight Hours Fueled Storage}

\begin{tabular}{|c|c|c|c|c|c|c|}
\hline Module & $\begin{array}{l}\text { Module } \\
\text { Number }\end{array}$ & $\begin{array}{c}\text { Module } \\
\text { Output } \\
\mathrm{KW} \\
\end{array}$ & $\begin{array}{l}\text { Weight } \\
\text { KG } \\
\end{array}$ & $\begin{array}{c}\text { Volume } \\
\mathrm{M}^{3} \\
\end{array}$ & $\begin{array}{c}\text { Cost } \\
\$ 1000^{\prime} s \\
\end{array}$ & $\begin{array}{c}\text { Efficiency } \\
\%\end{array}$ \\
\hline Power Processor & 2 & 1,000 & 5,740 & 24.5 & 108 & 96 \\
\hline Power Section & 6 & 1,042 & 8,594 & 20.0 & 2,604 & 53.7 \\
\hline Fuel Processor & 20 & 1,940 & 10,870 & 48.0 & 392 & 93.9 \\
\hline Fuel Storage & 29 & $\underline{2,066}$ & 2,862 & 4.7 & 3 & 100 \\
\hline Complete System & & 1,000 & 28,066 & 97.2 & 3,107 & 48.4 \\
\hline
\end{tabular}




\section{APPENDIX B}

\section{LAND VEHICLE APPLICATIONS}

1981

Transportation Innovations That Would Banish America's Energy Crisis. Dallaire, Eugene. ASCE, New York, NY, USA. Civ. Eng (New York) v 51 n November 11,1981 , pp. 47-50.

Despite the current oil glut, the energy crisis is still very much with us. Within the next few decades, the U.S. will nearly exhaust economically recoverable petroleum. The key to solving the energy crisis is to revolutionize the transportation sector, which now guzzles $55 \%$ of all petroleum used in the U.S. Technologies that could revolutionize transportation include the hybrid (gasoline-fired internal combustion engine plus batteries) car, vehicles powered by compressed natural gas, electrified highways, and fuel-cell-powered vehicles. The hybrid car is most promising as it could cut liquid fuel use in the transportation sector 50 to $80 \%$ in a decade. Also, the vehicles could be charged at night, without need to build a single new electric power plant in the country.

Status of New Electrochemical Storage and Conversion Technologies for Vehicle Applications. Landgrebe, A.R., Ruby, S., Kirk, R., Weinstock, I.B., Donley, S.W., Chudacek, R.C. U.S. DOE, Washington, DC, USA. Proc Intersoc Energy Convers Eng Conf 16th, v 1, Atlanta, GA, USA, August 9-14, 1981. Published by ASME, New York, NY, USA, 1981, pp. 738-743.

The use of battery- or fuel-cell-driven vehicles as a means of conserving petroleum fuel is addressed. Historical, current, and future aspects of electric vehicles are discussed, and brief summaries of most of the battery and fuel cell propulsion system candidate technologies are presented. 9 refs.

Design Considerations for Vehicular Fuel Cell Power Plants. Lynn, D.K., McCormick, J.B., Bobbett, R.E., Srinivasan, S., Huff, J.R. Los Alamos National Lab, NM, USA. Proc Intersoc Energy Convers Eng Conf $16 \mathrm{th}, \mathrm{v} 1$, Atlanta, GA, USA, August 9-14, 1981. Published by ASME, New York, NY, USA, 1981.

Fuel cells are presented as an efficient, nonpolluting vehicular power source that can operate on nonpetroleum fuel. As with other power sources, design tradeoffs can be made that either improve vehicle performance or reduce the size and cost of the fuel cell power system. To evaluate some of these tradeoffs, a number of phosphoric acid fuel cell power plant designs have been studied. 14 refs. 
Characteristics of an NH//3-Air Fuel Ce1l System for Vehicular Applications. Ross, Philip N, Jr. University of California, Berkeley, USA. Proc Intersoc Energy Convers Eng Conf 16 th $v 1$, Atlanta, GA, USA, August 9-14, 1981. Published by ASME, New York, NY, USA, 1981, pp. 726-733.

The use of hydrogen air alkaline fuel cell in a consumer vehicle application is examined. Liquid anhydrous ammonia was found to be an excellent storage medium for hydrogen, even though the endothermicity of the $\mathrm{NH} / 3$ cracking reaction results in some efficiency penalty. 14 refs.

Fuel-Cell-Powered Golf Cart. Bobbett, R.E., McCormick, J.B., Lynn, D.K., Derouin, C.R., Salazar, P.H., Kerwin, W.J. Los Alamos Sci Lab, NM, USA. EVC Expo 80 Conf Proc, St. Louis, MO, USA, May 20-22, 1980. Published by Electr Veh Counc., Washington, DC, USA, 1980 EVC n 8021, 7 pages.

This paper describes the implementation of a battery/fuel-cell-powered golf cart test bed designed to verify computer simulations and to gain operational experience with a fuel cell in a vehicular environment. A technically untrained driver can easily operate the golf cart because the motor and fuel cell controllers automatically sense and execute the appropriate on/off sequencing. A voltage imbalance circuit and a throttle compress circuit were developed that are directly applicable to electric vehicles in general.

Metal Hydride Fuel Cells: A Feasibility Study and Perspectives for Vehicular Applications. Folonari, C., Iemmi, G., Manfredi, F., Rolle, A. Fabrica Ital Automob Torino, Italy. J Less Common Met $v 74 \mathrm{n} 2$ October 15, 1980. Proc of the Int Symp on the Prop and App1 of Met Hydrides, Colorado Springs, Colorado, April 7-11, 1980, pp. 371-378.

Several alloys of the LaNi/5 family were tested in order to evaluate their thermochemical and electrochemical properties using repeated hydrogen absorption-desorption cycling. The alloys show good electrochemical properties, fast discharging and recharging kinetics, and high hydrogen absorption. On the basis of experimental results and theoretical evaluations, it is believed that the design of new types of fuel cells characterized by hydride electrodes and a solid electrolyte is technically feasible. 5 refs.

Alternate Power Plants and Fuels for Automobiles of the Future. Gupta, R.K., Ahluwalia, J.S. Indian 0il Corp., Faribadad, India. Energy Manage v 4 n 1 January-March, 1980, pp. 93-108.

A review of the status of development of alternate power plants and fuels for automobiles as well as current commercial and political outlook, suggests that internal combustion (IC) engines will continue to provide motive power to the automobiles for 
quite a few decades to come. The engines will move in the direction of greater adaptability to a variety of fuels. The external combustion engines have a headstart on this, but clever design of the combustion process in IC engines may prove to be the deciding factor for IC engine on this score. Battery systems are likely to appear in increased numbers in the mid-1980s in big urban areas for short trips and as delivery vans, because of emissions and noise limitations in those areas. Fuel cars may appear in early 1990s. Production will rise fairly rapidly, because of superior fuel economy and inherently low emissions. It is quite possible that the fuel cell may completely supplant other power systems by 2020. Regarding alternate fuels, synthetic fuels will appear in the market sooner than expected. These are going to become commercially viable soon. The automotive transportation fuels for use during this century will still be gasolines and distillates. By the mid-1980s fuels from biomass may play a bigger role. Increasing attention will be paid to producing fuels from municipal wastes. Ethanol, Methanol and Oxygenated compounds such as TBA and MTBE may be produced in such limited quantities that they will remain gasoline components rather than separate in most parts of the world. These fuels may constitute almost 20 per cent of the total gasoline pool by the year 2000. In the next century, as coal, oil shale and tar sand resources are depleted and coal derived synthetic fuels become more expensive, the most favored nonfossil fuel for transportation is hydrogen, with a nuclear reactor as the primary energy source. 44 refs.

Fuel Cell Systems for Vehicular Applications. Lynn, D.K., McCormick, J.B., Bobbett, R.E., Derouin, C., Kerwin, W.J. Los Alamos Sci Lab, NM. SAE Prepr n 800059 for Meet February 25-29, 1980, 12 pages.

Fuel cells show promise as a highly efficient, nonpolluting power source for vehicles; a power source capable of using nonpetroleum fuels. This report describes a number of design considerations and the projected performance of a fuel-cell-powered highway passenger vehicle. In addition, a fuel-cell-powered golf cart, which is currently being used as an engineering test bed, is described. 2 refs.

Energy Storage for Transportation. Mayo, James, W., Lendgrebe, Albert, R., Klunder, Kurt W., Nelson, Pau1, Cooper, John, Srinivasan, S., McBreen, J., McCormick, Brian. US DOE, USA. Energy Technol Proc Energy Technol Conf 7th, $v$, Expanding Supplies and Conserv, Washington, DC, USA, March 24-26, 1980. Pub by Gov Inst Inv., Washington, DC, USA, 1980, pp. 627-640.

The Energy Storage program of the U.S. Department of Energy proposes the development of secondary storage batteries, mechanically rechargeable batteries hydrogen storage, flywheels and fuel cells for automotive propulsion applications. The successful development of energy storage for this purpose 
proposes significant savings of oil resources and beneficial environmental effects. 3 refs.

Improved Alakaline Hydrogen/Air Fuel Cells for Transportation Applications. McBreen, J., Kissel, G., Kordesch, K.V., Kulesa, F., Taylor, E.J., Gannon, E., Srinivasan, S. Brookhaven National Lab, Upton, NY, Proc Intersoc Energy Convers Eng Conf 15th, Energy to the 2 lst Century, v 2, Seattle, Washington, August 18-22, 1980. Pub by AIAA, New York, NY, 1980, Pap 809174, pp. 886-891.

Considerable progress has been made in the last few years on improvement of alkaline air electrodes for air depolarized chlor-alkali cells. The cells were units in a 16-cell $0.5 \mathrm{~kW}$ module. This module yielded similar power densities, and its power/weight and power/volume are sufficiently attractive for it to be considered as a building block for a fuel cell power plant in a fuel cell/battery hybrid vehicle. 12 refs.

Case for Fue1-Ce11-Powered Vehicles. McCormick, J., Byron, Huff, James, R, Los Alamos Sci Lab, NM. Technol Rev v 82 n 8 August-September 1980, pp. 54-65.

The development of the fuel cell is briefly reviewed. Experimental applications of fuel cells in city buses, highway buses and trucks, delivery vans, consumer vehicles, and golf carts are described. For the most part these are hybrid powered vehicles in which storage batteries supply energy during warm-up and acceleration while the fuel cells supply energy at cruising speed and for battery recharge during vehicle stopping times. The economic viability of these configurations is emphasized. 17 refs.

Fuel Ce11s for Transportation. McCormick, J. Byron. Los Alamos Sci Lab, NM. Ind Res Dev v $22 \mathrm{n} 4$ Apri1 1980, pp. 88, 90, 92.

Results of an evaluation of fuel cell applications in city buses, highway buses, consumer vehicles, and delivery vans are briefly reviewed. Results of an economic analysis of the four target vehicles strongly suggest the feasibility of the fuel cell vehicle in the future.

Fuel Cells Show Promise as Vehicle Power Source. Anonymous. Automot Eng (Warrendale, PA) v 88 n 4 April 1980, pp. 78-84.

Fuel-cell-powered vehicles appear to offer great promise for energy-saving, high-efficiency transportation. Fuel cells are both highly efficient $(50 \%$ thermal efficiency has been demonstrated by some) and nonpolluting (water being the main by-product). Dramatic improvements in performance have occurred recently due to aerospace and utility R\&D efforts. The primary vehicle considered at workshops of laboratory and industrial investigators was a fuel cell/battery hybrid, in which fuel cells 
are paralleled by batteries. Fuel cells are used for cruising power and battery recharge, while batteries supply transient power for acceleration and starting.

Aluminum Air Unit Cell for Electric Vehicles Successfully Tested. Anonymous. Light Met Age v 38 n 11-12, December, 1980, p. 30.

A power cell which uses aluminum, air, and tap water as fuels has been tested at Lawrence Livermore National Laboratory in California.

Technico-Economic Study of Distributing Hydrogen for Automotive Vehicles. Breelle, Y., Gelin, P., Meyer, C., Petit, G. CEA, Saclay, Fr. Int J Hydrogen Energy v 4 n 4 1979, pp. 297-314.

This study attempts to estimate the technical and economic feasibilities of using hydrogen for automotive traction. The problems of bulk storage and transportation of hydrogen, capillary distribution, storage aboard vehicles, and problems concerning hydrogen thermal engines and hydrogen fuel cells are investigated. Different ways of using hydrogen, either compressed or liquefied or combined in hydrides, are considered. Energy and economic balance sheets lead to the conclusion that hydrogen internal combustion engines cannot compete with gasoline engines in terms of primary energy consumption and fuel cost. 21 refs.

Electric and Hybrid Vehicles. Collie, M. J. (Ed.). Energy Technol Rev $\mathrm{n} \mathrm{44,} \mathrm{Electr} \mathrm{and} \mathrm{Hybrid} \mathrm{Veh.} \mathrm{Publ} \mathrm{by} \mathrm{Noyes} \mathrm{Data} \mathrm{Corp,} \mathrm{Park} \mathrm{Ridge,}$ NJ, 1979,633 pages.

This assessment of electric vehicles summarizes data on characteristics, costs, maintenance and energy consumption gleaned from actual tests and from the literature and trade. It includes a survey of electric bus operations in 19 foreign and domestic locations and a survey of 11 different types of cars and delivery vans in the United States. Energy storage devices and power systems were analyzed as alternatives to current automobile propulsion systems, with the following batteries covered: $\mathrm{Pb} / \mathrm{acid}, \mathrm{Ni} / \mathrm{Zn}, \mathrm{Ni} / \mathrm{Fe}, \mathrm{Li} / \mathrm{FeS} / 2, \mathrm{Na} / \mathrm{S}, \mathrm{Zn} / \mathrm{Cl}, \mathrm{Ni} / \mathrm{H}, \mathrm{Zn} / \mathrm{Br}$, $\mathrm{Fe} / a i r, \mathrm{Li} / \mathrm{metal}$ sulfide, and others. The material presented in this book was selected from various research projects and investigations conducted by or for U.S. government agencies. U.S. Public law 94-413 distinguishes the subject vehicle types as follows: Sleft double quote\$ 'Electric vehicle' means a vehicle which is powered by an electric motor drawing current from rechargeable storage batteries, fuel cells or other portable sources of electrical current, and which may include a nonelectrical source of power designed to charge batteries and components thereof; 'Hybrid vehicle' means a vehicle propelled by a combination of electric motor and an internal combustion 
engine or other power source and components thereof. \$right double quotes Refs.

Applications of Fuel Ce11s in Transportation. McCormick, Byron, Bobbett, Ronald, Lynn, David, Srinivasan, S., McBreen, J., Huff, Jim, Nelson, Sam. Los Alamos Sci Lab, NM. Proc Intersoc Energy Convers Eng Conf 14th, v l, Boston, MA, August 5-10, 1979. Pub by Am Chem Soc., Washington, DC., 1979. Also available from IEEE (Cat $n$ 79CH1477-9 ENERGY), Piscataway, NJ, Pp. 613-616.

This report contains a detailed technical and economic evaluation of potential applications for fuel cells in transportation. Four vehicle types are evaluated: city bus, highway bus, delivery van, and consumer car, using fuel cell and reformer data supplied by Energy Research Corporation. Various fuel options and performance vs. economic tradeoffs are considered and final recommendations are presented.

Electric Automobiles: Citations from the Engineering Index Data Base. Hundemann, Audrey, S. (Ed.). NTIS, Springfield, VA. NTISearch NTIS/PS-76/0561/1EES. Search period covered 1970-June, 1976. Available from Eng Index, New York, NY or NTIS, 284 pages.

Citations from worldwide research cover the design of electric automobiles, vans, buses, and hybrid vehicles. Included are studies on lead-acid, zinc-air, lithium-sulfur, and nickel-cadmium batteries; fuel cells; drive trains; and chassis construction. Contains 284 abstracts.

Energy Analysis and the Electric Car. Williams, K.R. Shell Int Pet Co. SAE Prepr n 760120 for Meet February 23-27, 1976, 5 pages.

The energy which is necessary for both the construction and operation of a variety of cars is calculated and compared. It is concluded that the energy used in vehicle operation outweighs that used for construction. Battery-powered cars while showing no significant advantage in overall energy requirement over gasoline vehicles offer the possibility of substituting coal or nuclear energy for hydrocarbon fuels in vehicle propulsion. The only possibility for really widespread adoption of electric cars would come about if a successful and economic fuel cell were to be produced. Such as development could at least halve the hydrocarbon demands of the vehicle propulsion for a given mileage. Bearing in mind the fact that up to $50 \%$ of oil may be used in the transport sector, a practical fuel cell still seems a worthwhile, if elusive, target for research.

Power Plants and Future Fuels. Anonymous. Inst of Mech Eng, Combust Engines Group, London, England. Power Plants and Future Fuels, Conf. London, England, January 21-22, 1975. Published for Inst of Mech Eng, London, Engl by Mech Eng Pub1 Ltd (CP1-1975), London, Engl, 1976. Available in US from Mech Eng Pub1, New York, NY, 229 pages. 
Seventeen papers by various authors are presented. The topics discussed include: fuel consumption in passenger cars, the future of the automotive gas turbine; Stirling engines; fuel cells; high speed diesel engines; the operation of diesel engines on coal or its derivatives; the performance and emissions of spark ignition engines operating with alcohol-gasoline mixtures; methanol as a motor fuel; and the sodium/sulfur battery as a power source.

Economic and Technical Aspects of the C.G.E. Zn-Air Vehicle Battery. Appleby, A.J., Pompon, J.P., Jacquier, M. Cie Gen d'Electr, Cent de Rech, Marcoussis, Fr. Intersoc Energy Convers Eng Conf, 10th Rec, Univ of Del. Newark, August 18-22, 1975, Pap 759121, pp. 811-816. Pub by IEEE (Cat n 75CHO 983-7 TAB), New York, NY, 1975.

Electric vehicles are discussed in terms of power source requirements. It is shown that a refuelable fuel-cell type power source has certain advantage in terms of flexibility for the user. The zinc powder fuel cell, which may be recharged electrically either in our outside the vehicle, offers the advantages of both the fuel cell and the secondary battery. It is a system that requires no technical breakthrough, and will be economically attractive. It is capable of $110 \mathrm{wh} / \mathrm{kg}, 80 \mathrm{w} / \mathrm{kg}$. 7 refs.

Power Sources for Electric Vehicles. Kordesch, Kar1 V. Union Carbide Corp, Cleveland, OH. Mod Aspects Electrochem n 10, 1975, pp. 339-443.

This article contains a detailed discussion of automotive battery systems. It includes a number of tables that give electric-vehicle specifications, energy- and power-density requirements, criteria for electric car power sources, a comparison of battery systems, in particular the lead-acid battery (materials, methods of charging, and future improvements). Fuel cells (and hybrids) are also discussed extensively. 98 refs.

Improvements in Guided Land Passenger Transport Systems. Smith, S.F., Fairbrother, A.L. World Energy Conf, 9th, Trans. Pap and Discuss. Detroit, MI, September 23-27, 1974 v 7 pp. 23-39. Publ by US National Comm of the World Energy Conf. New York, NY, 1975.

Energy requirements of passenger transport systems and details of the energy usage of London Transport's fleet of 500 rapid transit trains and 6,000 buses are discussed. The development of the sodium-sulphur cell offers the possibility of a battery bus with a range of up to 200 kilometers. Data are presented in tabular and graphical form.

Electrical and Propulsion Systems for Road Vehicles. State of the Art and Present-Day Problems. Bader, Ch. Dtsch Automobiles, Res Lab, Esslingen, Germany. Int Electr Veh Symp and Expo. 3rd, Proc. 
Washington, DC, February 19-21, 1974, Pap 7478, 30 pages. Sponsored by Electr Veh Counc, New York, NY, 1974.

An analysis of various all-electric and electro-hybrid drive versions has revealed that at the moment the only possible source of energy for an electro-powered vehicle is the lead-acid battery, but that in the future alkaline and high-temperature accumulators might gain increasing importance since using these units might mean a reduction in operating cost of the vehicles thus equipped. As a result, optimization of electrical propulsion systems for road vehicles at the moment means to minimize the weight of the energy storage unit that is necessary to meet the specified transport requirements and to make the fullest possible use of the limited amount of energy available. Future developments in the field of electrical drive units should aim at cutting down the considerable cost of operation in the starting range due to the power electronic system in accordance within the comparatively short periods of operation within this range. A listing is shown (in German) of some experimental electric vehicles from various countries, some of which use internal combustion engines in a hybrid system, and others which use developmental alkaline or metal-air batteries, or fuel cells, or flywheel propulsion. 25 refs.

Battery Power for Electric Vehicles \$EM Dash\$ 2. Novel High Energy Power Sources. Barak, M. Elec Veh v 60 n 1 March 1974, pp. 12-18.

A review is presented of development work on some of the more unusual types of rechargeable batteries which have been considered as energy sources for electric vehicles. Among the types discussed are: silver oxide-zinc cells, fuel cells zinc-oxygen (or air) cells iron-air cells, sodium-sulfur cells, lithium-chlorine cells; zinc-chlorine batteries. The costs and technical problems of each of these systems are reported: for the present, none of these offers practical competition to the lead-acid storage battery for vehicle traction. A chart is given which shows the best estimates of the power-energy relationships of most of the power sources described, and based on these estimates, their capabilities (regardless of cost) of meeting the requirements of an electric automobile. of the systems described, the author concludes that the sodium-sulfur battery shows the greatest promise, but that much work is still needed to prove its commercial viability.

Using Hydrogen Fuel Cells for Urban Transportation. Breele, Y. Inst Fr du Pet, Paris. SAE Prepr n 740168 for Meet February 25-March 1, 1974,12 pages.

Considerable advances have been made in recent years in the field of hydrogen-air fuel cells, and plans are already being made to use such power generators for urban transportation. This is shown by a study of the possibility of equipping a vehicle of the 
Renault 4L type with a hydrogen-air cell. This paper describes a detailed study of such an installation. The weight of the power source is acceptable, as are the rates of acceleration. A speed of $80 \mathrm{~km} / \mathrm{h} \quad(50 \mathrm{mph})$ can be sustained continuously, and an

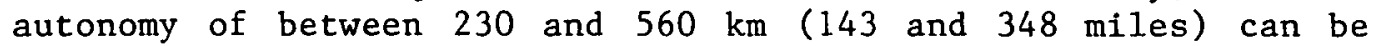
attained depending upon the speed of the vehicle, with an effective load of $340 \mathrm{~kg}(750 \mathrm{lb})$. Two important obstacles (power source and use of hydrogen) are inthe process of being solved by using inexpensive materials and by storing hydrogen by means of hydrides. Thus, the hydrogen-air fuel cell should be a decisive contribution to the use of electric vehicles, and its influence could become even greater if, on a long-term basis, the trend to make intensive use of hydrogen as an energy extension is confirmed. 13 refs.

Case for Electric and Fuel-Cell Powered Vehicles. Bockris, John O'M. Ambio v 3 n 1 1974, Pp. 15-23.

Potentially, the most feasible, intermediate-stage prime mover for vehicles, is a hybrid power plant. A composite system could utilize a conventional internal combustion engine at high speed, and an electric motor at low speed. At present, the primary barrier to developing practical lithium-chlorine or sodium-sulfur fuel cells is high temperature corrosion. Progress with commercial electric vehicles is also evaluated. 7 refs.

Feasibility of an Electrically-Propelled Vehicle Powered by Fuel Cells. Michel, Alfred, Frie, Wolfgang. Siemens, Erlangen, Ger. Int Electr Veh Sump and Expo, 3rd, Proc, Washington, dC, February 19-21, 1974 Pap 7452, 20 pages. Sponsored by Electr Veh Counc, New York, NY 1974.

Taking a minibus as an example, the standard driving cycle is used to show that at the present state of development it is technically feasible to build an electrically-propelled vehicle with satisfactory operating characteristics, fed by $\mathrm{H} / / 2 / 0 / / 2$ fuel cells and a conventional battery connected in parallel and, in the foreseeable future, by a fuel cell battery alone. Expressions are derived for the payload as a function of the operating range and for the specific operating costs. The author predicts that the fuel costs, if the hydrogen and oxygen are to be distributed by pipeline network, will be comparable to gasoline costs (present prices) for a comparable vehicle. The operating life of fuel cells, based on laboratory experience, is also expected to equal or exceed that of an internal combustion engine. 5 refs.

Air Pollution from Motor Vehicles and Its Control. Stern, A.C. Univ of NC, Chapel Hill. Iran Congr of Chem eng, 1st, Proc, Shiraz, Iran, May $14-17,1973$ v 2 pp. 449-472. Publ by Elsevier Sci Pub1 Co, New York, NY 1974. 
One way to decrease motor vehicle emissions is by controlling vehicular utilization. This can be accomplished by urban and traffic planning, by substitution of mass transit for individually operated vehicles, and by other means. Another way is by decreasing the emissions from individual internal combustion engine powered vehicles by changes in engine design. A third way is to substitute an alternate source of motive power for the conventional reciprocating internal combustion spark ignition or diesel engine. Among the possible alternate sources are rotary and stratified charge internal combustion engines, turbines, and electric or hybrid powered vehicles driven wholly or in part by storage batteries or fuel cells. These control means are all associated with time and cost factors required for their implementation as well as technological limitations on the feasibility of their accomplishment. 19 refs.

Auxiliary Services for a Fuel-Cell Hybrid Electric Car. Andrew, $\mathrm{Mr}$, Gressler, W.J., Johnson, J.K., Short, R.T., Williams, K.R. SAE Pap 720192 for meeting January 10-14, 1972, 14 pages.

This paper describes the development of the pumps, blowers, and electronic control systems for a fuel-cell/lead-acid-battery hybrid electric car. Wherever possible, commercially available equipment was used in order to reduce costs and expedite the completion of the vehicle. Considerable reductions in cost and complexity could be achieved if the pumps and motors were designed specifically for the car. The duplication of components could be avoided by using one set of batteries, each cell having twice the electrode area of the present one. The auxiliary pumps could then be reduced to a single electrolyte pump, the air blower and the nitrogen pump. All three pumps could be driven from the same motor.

Fuel- Cell/Lead- Acid- Battery Hybrid Car. Andrew, Mr, Gressler, W.J., Johnson, J.K., Short R.T., Williams, K.R. SAE Pap 720191 for meeting January $10-14,1972,7$ pages.

A prototype hybrid car has been made using as a power source two 12-cell hydrazine/air fuel batteries in conjunction with six conventional six-cell lead-acid accumulators. The performance of the car, in its present form, falls between that of today's internal-combustion-engined vehicles and that of secondary-battery-powered ones. However, unlike more conventional electric cars, its ranges under town driving conditions and at its steady cruising speed are not limited by the quantity of stored electricity. 10 refs.

Alternative Power Plants for Automotive Purposes. Estes, E.M. GM, New York, NY. Inst Mech Eng (Loridon), Proc v 186 PAP $11 / 71$ for Meet March 13, 1972, 18 pages. 
General Motors' latest progress with alternative power plants and their relative feasibility in both the near and more distant future is discussed. From viewpoint of the new legislation requiring exhaust emission control, the discussion deals with modified spark-ignition and diesel engines, gas turbines, battery and fuel cell electric drive, hybrid engine-electric drive, Stirling engines and Rankine cycle steam engines.

Candidate Batteries for Electric Vehicles. Gross, Sidney. Boeing Company, Seattle, Washington. Proc of Symp on Batteries for Traction and Propulsion, Columbus, $\mathrm{OH}$, March 7-8, 1972, Electrochem Soc. pp. $9-25$.

The purpose of this paper is to gather in one place brief summaries of most of the battery systems that can be considered for electric vehicles. Many little known systems are included, some with little or no experimental background; these are worthy of serious consideration and are suggested as possible avenues for future research. Conversely, well-known systems are discussed sparingly, for commentary on these is abundant. 100 refs.

Batteries for Ground Transportation Systems. Salomon, Mark. U.S. Department of Transportation, Cambridge, MA. Proc of Symp on Batteries for Traction and Propulsion, Columbus, $\mathrm{OH}$, March 7-8, 1972, Electrochem Soc, pp. 26-41.

An examination is made of lead-acid batteries, $\mathrm{Ni} / \mathrm{Zn}$ batteries, fuel cells, organic electrolyte batteries and high temperature batteries to determine their potential usefulness as portable power sources for use in electric vehicles. 18 refs.

Present Status of Electric Automobiles. Gottlieb, J.J. Nat Res Counc Can, Div Mech Eng, Quart Bull, Rep DME/NAE 4 October 1-December 31, 1970, pp. 3-72.

This study of the present state-of-the-art of electric vehicles was undertaken in order to present, in one document, the current status of research and development in this field. The scope of the study includes developments in batteries, fuel cells and hybrid systems, controllers, chargers, electric motors, and body design features. In addition, problems due to thermal conditioning and corrosion are discussed. 
Advanced Concepts in Chemical Propulsion Systems for a 500-Ton Submersible. Urbach, Herman B., Knauss, Donald T, Quandt, Earl R. David W. Taylor Nav Ship Res \& Dev Cent., MD. Nav Eng J v 93 n 1 February 1981, pp. 63-75.

This paper examines alternative advanced power systems designed to operate a 500-ton submersible with respect to overall weight and volume fractions. Candidate air-breathing, primary-power systems studied included Diesel, Closed-Brayton Cycle (CBC), and fuel cells. A number of options for underwater operation were based upon high-energy reactants replenishable from Base supplies. Another set of options was considered based upon using JP-5 fuel with \$left double quote\$ at sea \$right double quote\$ rechargeable secondary power systems, including thermal-energy storage, advanced lithium-sulfur batteries, or flywheels. 11 refs.

50 W Methanol-Air Fuel Cell with Hydrophobic Air Electrodes. Sylwan, Christopher. R Inst of Technol., Stockholm, Sweden. Energy Convers Manage v 20 n 1 1980, pp. 1-7.

A methanol-air fuel cell battery for light tractionary purposes has been built. The cell stack features platinum on carbon methanol electrodes, hydrophobic air electrodes and a new stack building technique based on metal 0-rings. 11 refs.

New Power Sources for a 14-Ton Submersible. Criddle, Ernest, E, Gardner, Christopher, L., Wake, Sylvia, J. Def Res Establ ottawa, Ontario. Proc Intersoc Energy Convers eng conf 13th, San Diego, CA, August 20-25, 1978. Publ by SAE (Cat n P-75), Warrendale, PA, i978. Also available from IEEE (Cat $n$ 78-CH1372-2 ENERGY), New York, NY, v 2, pp. 1208-1214.

A survey was made of batteries, engines and fuel cells to identify systems capable of providing the power required by a 14-ton submersible for propulsion, heating and emergency life support. Volume and weight limitations make it necessary that any new system have an energy density about three times greater than that of the lead-acid battery which is presently used in submersibles. Options of either a $20 \mathrm{~kW}$ electrical system or a $10 \mathrm{~kW}$ electrical plus $10 \mathrm{~kW}$ thermal system that makes use of waste heat for diver heating were studied. The silver-zinc battery and several converters operating on hydrogen and oxygen are acceptable: recycle Wankel engines, Stirling engines, alkaline fuel cells and Solid Polymer Electrolyte fuel cells, Their problems are discussed. 14 refs. 
Comparative Assessment of Power Sources for the Propulsion of Submarines. Wake, Sylvia, J., Criddle, Ernest, E., Gardner, Christopher, L. Def Res Establ Ottawa, Ontario. Proc Intersoc Energy Convers Eng Conf 13th, San Diego, CA, August 20-25, 1978. Publ by SAE (Cat n P-75), Warrendale, PA 1978. Also available from IEEE (Cat $n$ 78-CH1372-2 ENERGY), New York, NY v 2, pp. 1215-1221.

A comparative assessment has been made of nuclear, fuel cell and thermal engine power sources to propel a 2000 to 3500 ton submarine for under-ice surveillance, repairing deep sea oil rigs and for mineral exploration. For missions greater than 1000 hours, an intermediate enriched pressurized water reactor is identified as the most suitable power source, but the potential user must assess total system costs, enriched fuel supply and the potential acceptability of a nuclear system. In many cases a nuclear system is not desired, then with certain restrictions on vessel power and size, both Stirling engines and closed Brayton Cycle engines consuming diesel fuel and liquid oxygen are suitable. Furthermore, alkaline and solid polymer electrolyte fuel cells consuming liquid hydrogen and oxygen can also be used.

Marine Propulsion. Sladky, J. Jr., (Ed.) U.S. Naval Academy, Annapolis, MD. Mar Propul. Presented at the Winter Annual Meeting of the ASME, New York, NY, December 5-10, 1976. Published by ASME (DED v 2), New York, NY, 1976, 229 pages.

Nine papers by various authors are presented. The toxics discussed include: high performance ship propulsion systems; thrust augmenters; high performance marine propellers; waterjet propulsion; gas-augmented waterjet propulsion; intermittent propulsors; electric propulsion; marine batteries; and high energy density marine fuel cell systems. Individual papers are indexed separately.

High Energy Density Marine Fuel Cell Systems. Urbach, H.B., Woerner, J.A., David W. Taylor Nav Ship Research \& Development Center, Annapolis, MD. Mar Propul. Presented at the Winter Annual Meeting of the ASME, New York, NY, December 5-10, 1976. Published by ASME (DED v 2). New York, NY, 1976, pp. 217-222.

Although the power-weight ratio of the DSRV power plant is attractive when compared with batteries and diesel engines, it is the energy-weight ratio which motivates fuel-cell application. Examination of the energy subsystem of the DSRV vehicle shows that the plant is capable of providing only $0.22 \mathrm{kWg} / \mathrm{kg}$ of energy system weight because $35 \mathrm{~kg}$ of pressurized hydrogen are stored in $2180 \mathrm{~kg}$ of pressure vessel. Analysis reveals that fuel-cell energy systems utilizing light metal hydrides and peroxide yield significant increases in energy-weight ratios and, therefore, endurance. One hydride system comprised of $\mathrm{LiH}$ and $\mathrm{H} / / 20 / / 2$ is almost neutrally buoyant so that when the energy package is located outside the pressure hull, $0.83 \mathrm{kWh} / \mathrm{kg}$ is 
yielded. A conceptual design of an advanced work vehicle of 50 metric tons fitted with an advanced DSRV fuel cell and $\mathrm{LiH}-\mathrm{H} / / 20 / / 2$ energy package appears to be capable of a top speed of $14 \mathrm{~km} / \mathrm{h}$ ( 8 knots) or an uninterrupted deep submersible operation of 135 hours. 17 refs.

Hydrogen Production Storage, and Conversion for Electric Utility and Transportation Applications. Srinivasan, S., Wiswall, R.H. Brookhaven National Lab, Upton, NY. Proc of the Symp on Energy Storage, 148th Meet of the Electrochem Society, Dallas, TX, October 5-9, 1975. Published by Electrochemical Society, Inc., Princeton, NJ, 1976, pp. 82-108.

At the present time, the energy efficiency for hydrogen production by water electrolysis is about $75 \%$. With improved catalysts, higher operating temperatures and better separator materials in advanced systems (Teledyne, Lurgi, and General Electric water electrolyzers), it should be possible to carry out water electrolysis at close to $100 \%$ efficiencies. The storage of hydrogen as a metal hydride shows significant advantages over the cryogenic or compressed gas procedures. For electric utility applications, its feasibility has been demonstrated using an iron-titanium alloy. Though this alloy may also be suitable for hydrogen storage in buses and trains, it will be necessary to consider the lighter hydrides for automobiles. With fuel cells or combined cycle gas turbines, it should be possible to attain energy conversion efficiencies of about $60 \%$. The present status and potential for improvements in acid, alkaline, molten carbonate, and solid oxide fuel cell systems are briefly summarized. 18 refs.

High Power Fuel Cells for Undersea Applications. Heath, C.E., Verger, B., Hespel, C., Fauve1, P. Alsthom/Exxon, Massey, Fr. Intersoc Energy Convers Eng Conf., 9th, Proc., San Francisco, CA, August 26-30, 1974, Pap 749069, pp. 646-653. Available from ASME, New York, 1974.

This paper reviews the basic cell and system concepts and describes fuel cell modules currently in production based on these concepts, including the performance presently achieved. These modules have been incorporated into systems yielding 100 $\mathrm{kW}$, which are described. Undersea applications for hydrazine hydrogen peroxide fuel cells are discussed and the fuel cells are compared with alternate electrical generators. 3 refs.

Fuel Cell Powerplant for Deep-Submergence Vehicles. Sanderson, R.A., Landau, M.B., Spadone, D.M. SAE Pap 710826 for meeting October 26-29, 1971 , 5 pages.

A 20-kW-fuel-cell-powered plant is being developed to power undersea vehicles for deep submergence. The power plant consists of alkaline fuel cells and auxiliary components for heat and product water management located in a containment vessel. A 
multiplex-control system minimizes electrical penetration of containment vessels. This power plant, designated powercel 15A, when supplied with gaseous hydrogen and oxygen stored at high pressure, will deliver 93 whr/lb for its designed 36 hour $250 \mathrm{k}$ whr mission, which is three times the energy density of the best batteries in service today. 


\section{REMOTE STATIONARY POWER}

Fuel Cells Show Promise for Pipeline-Station Power.

Ragsdale, Harold E., Rice, Robert C., Hartley, George R.

Bechtel Pet Inc., Houston, Texas, USA

Oil Gas J v 79 n 45 November 9, 1981, 5 p between p. 226 and 231.

Fuel cells, which produce electricity directly from hydrocarbon fuels such as natural gas, naphtha, or even coal, can now be purchased which, when combined with electronic speed control, will operate at higher efficiencies and produce less pollution than conventional engines. This study traces the development of the fuel cell and explains how it can be used for pipeline pumping and compression.

Fuel Cells for Telecommunications.

Eguchi, Norio, Ogasawara, Masanori

Nippon Telegr + Teleph Public Corp., Japan

Japan Tellecommun Rev v 22 n 1 January 1980 p 75-79

A fuel cell system as a power supply for telecommunications at remote areas has been developed. Two fuel cell systems, hydrazineoxygen fuel cells and hydrazine-air fuel cells, were manufactured and have been under field tests for the purpose of determining characteristics in intermittent operational mode. They are expected to be introduced early as a hybrid power source or standby power source for telecommunications.

Early Prospects for Fuel Cells

Blurton, Keith F.

Inst of Gas Technology, Chicago, I1linois

Symp Pap - New Fuels and Adv in Combust Technol, New Orleans, Louisiana, March 26-30, 1979, Publ by Inst of Gas Technology, Chicago, Illinois, 1979, p 657-667.

Considerable interest is being shown in the fuel cell by gas and electric utilities and by industry because of its high efficiency, environmental compatibility, fuel flexibility, modularity, waste heat recovery capability, instant load response, and unattended operation. The gas industry is interested in onsite fuel cells that recover byproduct heat and provide the thermal energy at the location in addition to the electrical requirements.

Power Supplies for Telecommunications in Remote Areas.

Haboeck, Adolf, Schmalzl, Franz

Siemens, Germany

INTELEC It Telecommun Energy Conf Proc Washington, DC, November 26-29, 1979. Publ by IEEE (Cat n 79CH1502-4), Piscataway, NJ, p 30-37 
Repeater stations in telecommunication networks are often located in unpopulated areas without a developed infrastructure or a public power supply. DC power must be supplied by electric power generating equipment at each station. In addition to the well established means of generation, new methods are.finding increasing application. Photovoltaic, wind energy, and fuel cell systems are described, and their suitability for use for telecommunications applications is discussed.

Fuel Cell Plant for Autonomous Power Supply.

Cnobloch, H., Kohlmueller, H., Kueh1, D.

Siemens Res Lab, Erlanger, Germany

Energy Convers v 14 n 3-4 July 1975, p 75-79

The construction and testing of an operating model of a $7 \mathrm{~kW}$ hydrazine/oxygen fuel cell plant is described. The oxygen is obtained by catalytic decomposition of hydrogen peroxide immediately prior to use. The maximum output of the plant is $11.2 \mathrm{~kW}$ $(100 \mathrm{~A}, 112 \mathrm{~V})$. An electronic system controls starting, automatic operation and shutdown. Starting takes 1-2 min. The overall efficiency of the entire plant \$EM DASHS referred to the hydrazine \$EM DASHS is 0.51 .12 refs.

Selection of Power Sources for Remote Ocean Oriented Applications. McCartney, J.F., Cates, M.A.

Nav Undersea Cent, California

IEEE Conf on Eng in the Ocean Environ and Mar Technol Soc, 11 th Annu Meet, Proc, San Diego, California, September 22-25, 1975, p 741-750, Pub1 by IEEE ( 75 CHO 995-1 OEC), New York, NY, 1975

Overview of electric power supplies suitable for remote applications is given for missions requiring low average power and long life. Included are radioisotope power generators, sealed chemical batteries, seawater batteries, transmission cables, fuel cells, gas-fired thermoelectric generators, solar batteries and wind generators. Diagrams and tables show data.

Selection of Power Sources for Remote Ocean Oriented Applications. McCartney, J.F., Cates, M.A.

Nav Undersea Cent, San Diego, California

Intersoc Energy Convers Eng Conf, 10 th, Rec, Univ of Del, Newark, August 18-22, 1975, Pap 759193, p 1318-1327. Publ by IEEE (Cat n 75CHO 983-7 TAB), New York, NY, 1975.

The purpose of this paper is to aid mission planners and design engineers in choosing the best available power system to satisfy the power requirements for a particular mission. It provides an overview of electric power supplies suitable for remote applications. Particularly, emphasis is placed on power supplies for missions requiring low average power and long life. Included are radioisotope power generators, sealed chemical batteries, sea water batteries, transmission cables, fuel cells, gas-fired thermoelectric generators, solar batteries, and wind generators. 
Electricity for Developing Areas Via Fuel Cell Powerplants.

King, Joseph M., Folstad, Sigurd H.

Pratt + Whitney Aircr, East Hartford, Connecticut

Intersoc Energy Convers Eng Conf, 8th, Proc. pap, Univ of Pa, Philade1phia, August 13-17, 1973, p 111-115. Publ by AIAA, New York, 1973.

Fuel cells are examined as potential means of meeting the needs of developing countries by providing new power supply options. The general characteristics of underdeveloped countries are outlined, and the conventional techniques used to provide power within the framework of these characteristics are discussed. Following this, the characteristics of fuel cells, their potential impact on the economics of power supply in developing countries, and the present status of fuel cell powerplants are described. 3 refs.

Comparative Evaluation of Power-System Types.

Wimmer, R.E.

Isotop Radiat Technol, v 9 n 2, Winter 1971-72, p 235-7.

Comparison of possible energy sources for underseas missions indicates that as the mission time duration increases, batteries give place to fuel cells and they, in turn, to nuclear systems. Isotopic systems are preferable to nuclear reactor systems only at low power levels. 
REMOTE PORTABLE POWER

Assessment of the Solid Polymer Electrolyte Fuel Cell for Mobile Power Plants.

McElroy, J.F.

GE, Wilmington, Massachusetts

Proc of the Power Sources Symp, 28th, Atlantic City, NJ, June 12-15, 1978. Publ by Electrochem Soc, Princeton, NJ, 1978, p 32-34.

The long demonstrated 1 ife of both the hydrogen/oxygen and hydrogen/air solid polymer electrolyte fuel cell combined with its compatibility with the $\mathrm{CO}_{2}$ in both reactants makes the SPE fuel cell concept an attractive terrestrial powerplant. Future cost projections as low as $\$ 100 / \mathrm{kW}$ see possible with the demonstration of performance at or above 1 . $0 \mathrm{~A} / \mathrm{cm} * * 2$ and selection of a slightly larger system rating (e.g., $25 \mathrm{~kW}$ ) would also drive costs toward the $\$ 100 \mathrm{~kW}$.

EPA-Van. A Clean Energy System for the Home.

Bunas, Stanley J., Collins, Martin F., Terry, Peter L.

EPA, Control Syst Lab, Res Triangle Park, North Carolina

Intersoc Energy Convers Eng Conf, 10 th, Rec, Univ of Del, Newark, August 18-22, 1975, Pap 759039, p 241-246. Pub1 by IEEE (Cat n 75CHO 983-7 TAB), New York, NY, 1975.

The EPA-Van, a research unit designed as part of EPA's research program to control air pollution, is an energy supply system for the home which contains environmentally clean and energy-conserving components. The EPA-Van is designed to be mobile for experimental testing in various parts of the United States. The EPA-Van's energy supply system includes fuel cells, a solar energy collector, a heat pump, and catalytic appliances. This essentially nonpolluting equipment is integrated so as to optimize the energy-conserving features which characterize each of its components. The integrated system provides all the energy needed by the EPA-Van for space heating, cooling, and ventilating, cooking, lighting, food refrigeration, water heating, and for appliances. 5 refs.

Fuel Cells - A Means of Energy Conversion with Minimum Wastage.

Van den Berghe, P., Tannenberger, H.

Battelle, Geneva Res Cent, Switzerland

IEE Conf Publ (Lond) n 112, 1974, for Meet, London, England, May 6-9, $1974, \mathrm{p} 178-183$

The efficiency and economic aspects of fuel cells are evaluated. Factors influencing the use of various materials are discussed. Two main applications of FC with a major impact on the energy consumption pattern are considered: stationary, medium-power $\$$ left double quote\$ total energy $\$ r i g h t$ double quote\$ systems and mobile applications. 
ENERGY STORAGE

Electric Properties of Refractory Oxides in Relation to the Conversion, Storage and Conservation of Energy.

Anthony, Anne Marie

Cent de Rech sur la Phys des Hautes Temp, Orleans, France

High Temp High Pressures v 13 n 11981 p 1-7

The electronic and ionic contributions to the electric properties of refractory oxides - particularly zironia - are briefly reviewed. Applications of these materials in the field of energy technology, which depends on these properties, are summarized and briefly discussed. These applications are divided into three basic areas: (i) energy conversion, as in magnetohydrodynamic and fuel cell systems; ( $i i)$ energy storage, especially methods for production of hydrogen by use of solar energy, suchn as thermodynamic cycles, electrolysis, photolysis, and thermolysis; (iii) energy conversion, as in oxygen sensors and high temperature insulating materials. Refs.

Energy Storage Technology - Environmental Implications of Large-Scale Utilization.

Krupka, M.C., Moore, J.E., Keller, W.E., Baca, G.A., Brasier, R.I., Bennett, W.S.

Los Alamos Sci Lab, NM, USA

Alternative Energy Sources 2, Proc of the Miami Int Conf, 2nd, v 1, Sol Energy 1, Miami Beach, Fla, USA, Dec 10-13, 1979. Pub1 by Hemisphere Publ Corp., Washington, DC, USA, 1981. Distrib outside USA by McGrawHill Int Book Co, p 265-284.

The energy storage technologies under study included: advanced lead-acid battery, compressed air, underground pumped hydroelectric, flywheel, superconducting magnet and various thermal systems (sensible, latent heat and reversible chemical reaction). In addition, a preliminary study was conducted on fuel cell technology. Detailed discussions of a number of environmental impacts from the latest LASL study as they related to primarily operational situations are emphasized. 33 Refs.

Materials for Energy Conservation and Storage.

Tofield, B.C.

AERE, Harwell, Oxfs, England

Appl Energy v 8 n 2 Jun 1981 p 89-142.

Some areas of energy use where improved materials could lead to energy savings are surveyed. Current energy use patterns and their likely evolution to the end of the century are al so reviewed. Areas such as improved engine-management of internal combustion engined vehicles and improved batteries for electric vehicles, where 
progress depends very much on materials developments, are surveyed in more detail. Energy storage procedures are surveyed, together with a discussion of electricity generating methods and future electricity use. Attention is given to current fuel cell programs, which offer the potential of increased conversion efficiency of fossil fuel to electricity compared with conventional power stations but where materials problems are critical in determining commercial success, to heat storage materials, and to water electrolysis and hydrogen production as a means of energy storage. The utilization of electrochemical processes in solids or at surfaces or interfaces is a general theme underlying many of the technologies discussed. 108 refs. 
Properties of the Polyol Fuel Cell.

Gillet, I., Linard, R.

Univ of Liege, Belgium

IEE Conf Publ n 192, Int Conf on Future Energy Concepts, 3rd, London, Eng1, Jan 27-30, 1981. Publ by IEE, London, Engl and New York, NY, USA, 1981 p $85-86$

Biomass can provide large quantities of renewable electrochemical fuels which can be used in fuel cells. Some of these fuels, the polyols, have definite advantages, but before they can be put to practical use, much experimental investigation is still needed. It is a matter of long term fundamental research. The general formula of polyols and their properties are presented. The stoichiometric equation for the electrochemical combustion of the polyols in a fuel cell is given.

Utility Fuel Cells for Biomass Fuel.

Lindstrom, 0., Nilsson, T., Burse11, M., Hornell, C., Karlsson, G., Sylwan, C., Ahgren, B.

$\mathrm{R}$ Inst of Technol, Stockholm, Sweden

Proc Intersoc Energy Convers Eng Conf 13 th, San Diego, Calif, August 2025, 1978. Publ by SAE (Cat n P-75), Warrendale, Pa 1978. Also available from IEEE (Cat n 78-CH1372-2 ENERGY), New York, NY v 2 p 1178-1184.

The fuel cell system comprises a fuel processor for conversion of biomass and peat to hydrogen, and alkaline fuel cells. The fuel processor uses a modified steam iron process. A conceptual $100 \mathrm{MW}$ plant is using so-called FC-041. 5 MW generator units. Fuel cell cathodes consist of nickel screens emedded in PTFE bonded silver catalysts and give $1 \mathrm{kA}$. mm** $\$$ minus $\$ * 2$ in the ange $\$$ minus $\$ 0.11$ to \$minus\$ 0. $21 \mathrm{~V}$ vs. $\mathrm{Hg} / \mathrm{HgO}$. Anodes with skeleton-nickel from AlNiTiMo alloys \$minus\$ $0.87 \mathrm{~V}$. The pseudoresistivity of the cathodes is inversely proportional to the 0.7 th power of the oxygen partial pressure. 15 refs.

Hybrid Power Source for Material Handling Equipment.

O'Sullivan, J.B., Dowgiallo, E.J., Snellings, I.R.

U.S. Army Mobil Equip R+D Cent, Ft. Belvoir, Virginia

Intersoc Energy Convers Eng Cnf, 10 th, Rec, Univ of De1, Newark, Aug 1822, 1975 Pap 759037 p 229-236. Publ by IEEE (Cat n 75CHO 983-7 TAB), New York, NY, 1975.

A hybrid power source is composed of differing power sources which operate in parallel, i.e., load share, into a common demand. These hybrid power sources are designed to optimize some set of characteristics (size, weight, performance, efficiency, etc.) which 
are not met with either component power source. Material handling equipment (MHE) applications have load profiles which indicate that hybrid power sources may be advantageous for improved performance and efficiency. The profiles of some MHE applications have been analyzed and used for design of a hybrid power source composed of a fuel cell and a battery. 6 refs. 


\section{MISCELLANEOUS APPLICATIONS}

Fuel Cell System Without Noble Metals on the Anode; Realization, Application and Economics.

Fleischmann, R., Boehm, H.

AEG-Telefunken, Frankfurt, Germany

Proc Intersoc Energy Convers Eng Conf 16th, v i, Atlauta, Ga, USA, Aug

9-14, 1981. Pub1 by ASME, New York, NY, USA, 1981 p 734-737.

A review of the current phosphoric acid fuel cell development without noble metal on the anode is presented. Application and economic calculations help to find the right level for market introduction and may influence further development. 4 refs.

State of Research and Prospects for Direct Conversion of Various Forms of Energy into Electric Energy.

Lidorenko, N.S.

Sov Electr Eng v 48 n 111977 p 24-29

A brief survey of the research carried out by the All-Union Scientific Research Institute for Current Sources on various electric generating devices is presented. In particular, various photoconverters, solar cells, thermogenerators, chemical cells and batteries are briefly described. Utilization of direct conversion systems in data processing elements is surveyed.

In-flight Oxygen Generation for Aircraft Breathing Systems. Boscola, Edward J.

Nav Air Dev Cent, Warminster, $\mathrm{Pa}$

J Aircr v 11 n 8 Aug 1974 p 444-448

Operational and logistics problems associated with liquid oxygen (LOX) breathing supply systems have shown the need for developing methods of generating oxygen directly on board the aircraft for aircrew breathing. Concepts presently being developed are based upon fluomine chemical sorbent and electrochemical concentrator processes. The fluomine process is a temperature cycled chemical system using the fluomine for reversibly sorbing oxygen from a combination fuel cell and electrolysis cell reaction to generate oxygen. Oxygen from an air stream is reduced on the cathode to form water, the water is then electrolyzed at the anode to evolve pure gaseous oxygen. With the aid of necessary aircraft resources (electrical power, air, heating, and cooling), these techniques extract oxygen directly from the engine bleed air during all flight operations. 5 refs. 
Framework for Evaluating the Socioeconomic Impacts of Commercializing New Energy Technologies with an Application to the Onsite Fuel Cell Energy System.

Sangahvi, A.P., Ciliano, R., Johnson, R.

ICF Inc, Washington, DC

Energy (Oxford) v 5 n 12 Dec 1980 p 1231-1244

Such impacts can be broadly classified as economic development impacts, environmental impacts, and "other" societal impacts. The steps involved in a public sector cost-benefit analysis are discussed, starting with impact identification and then proceeding to impact analysis, impact valuation, and benefits of the energy technology under study. This process is illustrated by applying it to the assessment of the dollar value of net potential benefits likely to accrue to the public sector from commercialization of the onsite fuel energy system. This analysis indicates that the potential benefits from dispersed deployment of the fuel cell make it a desirable source of energy, given the national energy priorities. Commercialization will result in substantial savings to consumers, in more efficient utilization of the nation's energy and nonenergy resources, and in an ameliorative effect on the environment. 6 refs.

Energy Research and Development Program of the United States. Myers, Dale D.

DOE, Washington, DC

Energy and Aerosp, Proc, An anglo Am Conf Organ by R Aeronaut Soc and the AIAA, London, Engl, Dec 5-7 1978. Publ by R Aeronaut Soc, London, Engl, $197811 \mathrm{p}$.

Energy situation in USA is outlined and some programs discussed where aerospace technology can be used to develop energy production from alternative sources, including central solar technology, photovoltaics, wind turbines, fuel cells, breeder reactors, thermonuclear fusion, and solar power satellites.

Possibilities for Integration of Electric, Gas, and Hydrogen Energy Systems.

Casazza; J.A., Huse, R.A., Sulzberger, V.T., Salzano, F.J.

Public Serv Electr and Gas Co, Newark, NJ

Int Conf on Large High-Voltage Electr Syst, 25 th Sess, Bull n 1, Paris, Fr, Aug 21-29 1974 Pap 31-07, 12 p. Publ by CIGRE, Parish, Fr, 1974.

Parametric analyses are presented showing relationships between the use of hydrogen as fuel and the development of electric systems, including consideration of coordination between electric and gas systems. The potential role of the fuel cell is stressed. Economic 


\begin{abstract}
"breakeven" capital cost differentials are given for fuel cells supplied with fossil fuels vs. fuel cells supplied with hydrogen made at off-peak times by electrolysis, for a hydrogen made at offpeak times by electrolysis, for a hydrogen-fuel cell energy storage system vs. electrochemical energy storage, and for an "energy transformer" which would make possible the two-way transfer of energy between electric and gas networks. Also included is information on the present and future methods for producing, storing, and transmitting hydrogen.
\end{abstract}

Prospects and Scientific Problems of the Utilization of Methods of Direct Electric Power Generation from Chemical Fuels (Fuel Cells). Lidorenko, N.S.

Muchnik, G.F.

Heat Transfer Sov Res v 6 n 3 May-June 1974 p 12-24.

The principal prospects are examined of the utilization of fue 1 cells for converting chemical energy of fuels into electric power. The optimal fields of fuel cell utilization as compared with other energy sources are established. The comparison is carried out on the basis of a number of criteria, including economic considerations. 11 refs.

Fuel Cells: Past, Present and Future.

Tantram, A.D.S.

City Univ, London, Engl

Energy Policy v 2 n 1 Mar 1974 p 55-66.

The author charts the development of fuel cells from early laboratory experiments to the highly efficient, but expensive cells used in the Apollo space program and assesses their future commercial prospects. 8 refs.

Unified Framework for Energy System Planning.

Hoffman, Kenneth C.

Brookhaven Nat1 Lab, Upton, NY

Energy Model, Semin, Work Pap, Washington, DC, Jan 25-26 1973 p 108-143. Publ by Resour for the Future, Inc (Work Pap En-1), Washington, DC, 1973.

A linear programming model of the U.S. energy system is developed to provide a framework for planning and technology assessment. The model encompasses the entire energy system and reflects the full feasible range of interfuel substitutability. It includes both electric and non-electric energy forms and focuses on the technical, economic, and environmental characteristics of the energy conversion, delivery, and utilization devices that make up the energy system. The model, in its current form, has 13 supply categories and 15 demand categories and the impact of several new technologies has been evaluated using a set of supply and demand constraints estimated for the year 2000. The technologies that were evaluated ae a high-performance nonelectric air conditioner, and electric automobile, and fuel cells. 9 refs. 
Design Considerations for Vehicular Fuel Cell Power Plant; D. K. Lynn et al, Los Alamos, N. M.

\section{RESULTS}

A number of fuel cell power plant designs were studied to determine the performance level they could provide for a compact passenger car and a 40-ft. city bus. The fuel cell considered as a baseline was the phosphoric acid fuel cell (PAFC) operating on steam reformed methanol. Two advanced fuel cells were also considered. The first has a voltagecurrent curve increased by $75 \mathrm{mV}$ over the baseline; the second is increased by $150 \mathrm{mV}$. Two baseline designs were considered: one for maximum performance and the other for minimum cost. Data provided include total weight, fuel cell weight, miles per gallon, 0-50 mph time, top speed, fuel cell efficiency and other.

\section{CONCLUSIONS}

The study concluded that fuel cells show great promise for both the consumer vehicle and the city bus.

\section{LIMITATIONS}

Costs were not considered.

Metal Hydride Fuel Cells: A Feasibility Study and Perspectives for Vehicular Applications; C. Folonari et al, Fiat Research Centre.

\section{$\underline{\text { RESULTS }}$}

The technical feasibility of metal hydride fuel cells for vehicular applications are examined. First a $1 \mathrm{~kW}$ fuel cell was constructed and operated for evaluation purposes and then an $18 \mathrm{~kW}$ prototype fuel cell was compared to conventional lead-acid batteries.

\section{CONCLUSIONS}

The utilization of the fuel cell instead of lead-acid batteries in the electric vehicle nearly triples the density of stored energy at cruising speeds and allows a much longer range for a smaller volume and weight, leaving more room available for payload.

\section{LIMITATIONS}

Costs were not considered. 
Improved Alkaline Hydrogen/Air Fuel Cells for Transportation Applications; J. McBreen et al.

\section{RESULTS}

Some of the electrodes developed by Union Carbide were evaluated at Brookhaven National Laboratory in alkaline hydrogen/air fuel cells. Performance curves and descriptions of the various electrodes are included. A comparison of a reformed methanol/phosphoric acid fuel cell to a hydrogen/alkaline cell including major advantages and disadvantages of each is shown below.

\section{Advantages and Disadvantages of Fuel/Fuel Cell Options}

\section{Reformed Methanol/Phosphoric Acid}

Methanol

- Advantages

- Storage and distribution similar to gasoline

- Disadvantages

- $\mathrm{CO}_{2}$ emissions

- Economics uncertain

Phosphoric acid fuel cell

- Advantages

- Not affected by $\mathrm{CO}_{2}$ ingress

- Long life has been demonstrated

- Technically most advanced

- Engineering aspects such as water management are simple

\section{- Disadvantages}

- Requires Pt electrocatalysts

- Operates at $\sim 200^{\circ} \mathrm{C}$, i.e., slow startup ( $15 \mathrm{~min}$ )

- Design of shock and vibration resistant structures is difficult

\section{Hydrogen/Alkaline}

Hydrogen

- Advantages

- High energy content

- No $\mathrm{CO}_{2}$ emissions at end-use site

- Disadvantages

- Distribution and storage very different from present infrastructure

- Economics uncertain

Alkaline fuel cell

- Advantages

- Does not require Pt electrocatalysts

- Yields up to $50 \%$ of rated power ambient temperature, i.e., fast startup ( $2 \mathrm{~min}$ )

- Rugged metallic structures can be built

- High efficiency

- Dișadvantages.

- Not tolerant to $\mathrm{CO}_{2}$ ingress

- Engineering aspects such as water management more difficult

- Lifetime still uncertain 


\section{CONCLUSIONS}

Many of the technical obstacles of fuel cells have been overcome. However, economic viability is still uncertain.

\section{LIMITATIONS}

Fuel cells were evaluated in general with little emphasis on specific applications. Costs were not considered.

The Case for Fuel Cell Powered Vehicles; J. B. McCormick, J. R. Huff.

\section{RESULTS}

Various potential vehicular applications are examined for fuel cell and compared to diesel options. Examples are shown below.

\section{CONCLUSIONS}

When operating costs are considered (e.g., for highway buses savings of $1.56 \mathrm{c} / \mathrm{mile}$ are expected from the fuel cell option resulting in total savings of $\$ 15,600$ for 1 MM miles $\& \$ 13,400-\$ 33,400$ savings due to reduced maintenance costs), the fuel cell option seems rather reasonable.

\section{LIMITATIONS}

The economics seem rather optimistic and are based on large production rates.

Advanced Concepts in Chemical Propulsion Systems for a 500-Ton Submersible: H. B. Urbach, D. T. Knauss, E. R. Quandt. 


\section{RESULTS}

Various models of Non-Nuclear Underwater Transportation are examined. They include Diesel, Closed-Brayton Cycle, Alkaline fuel cells, LithiumSeawater fuel cells, and Lithium Peroxide cells. Information regarding the power requirements for underwater travel, characteristics of each fuel cell type and related problems (e.g., Lithium-Seawater fuel cells produce hydrogen whose escaping bubbles would disclose the location of the submersible) are provided. Some information on auxiliary systems such as $\mathrm{H}_{2} \& \mathrm{O}_{2}$ generation, heat exchangers, and tank is included. A number of options for underwater operation were based upon high-energy reactiants replenishable from Base supplies. Another set of options was considered based upon using JP-5 fuel with "at-sea" rechargeable secondary power systems.

\section{CONCLUSIONS}

Replenishable high-energy reactant systems were on average lower in weight and volume than the rechargeable systems for the same submerged mission profile. Moreover, the replenishable systems permitted and extended tactical encounter with a maximum duration of 8 to 17 hours at speeds of 30 knots without the need to resurface and recharge a secondary energy storage device.

\section{LIMITATIONS}

The study is applicable to a very specific type of submersible (military use only) presently using a nuclear power system. Since nuclear power systems were not considered in this study, it is difficult to evaluate the actual feasibility of fuel cells. No cost information was available.

Marine Propulsion; L, Sladky, Jr.

RESULTS

A conceptual design of an advanced work vehicle of $50 \mathrm{~T}$ fitted with a $\mathrm{LiH}-\mathrm{H}_{2} \mathrm{O}_{2}$ fuel cell energy package is described. The characteristics of the power system including weight, storage and flow diagrams are provided. Hydrazine fuel cells are also described. The expected performance of a $50 \mathrm{~T}$ fuel cell powered submarine vehicle with extended mission time is given below. 


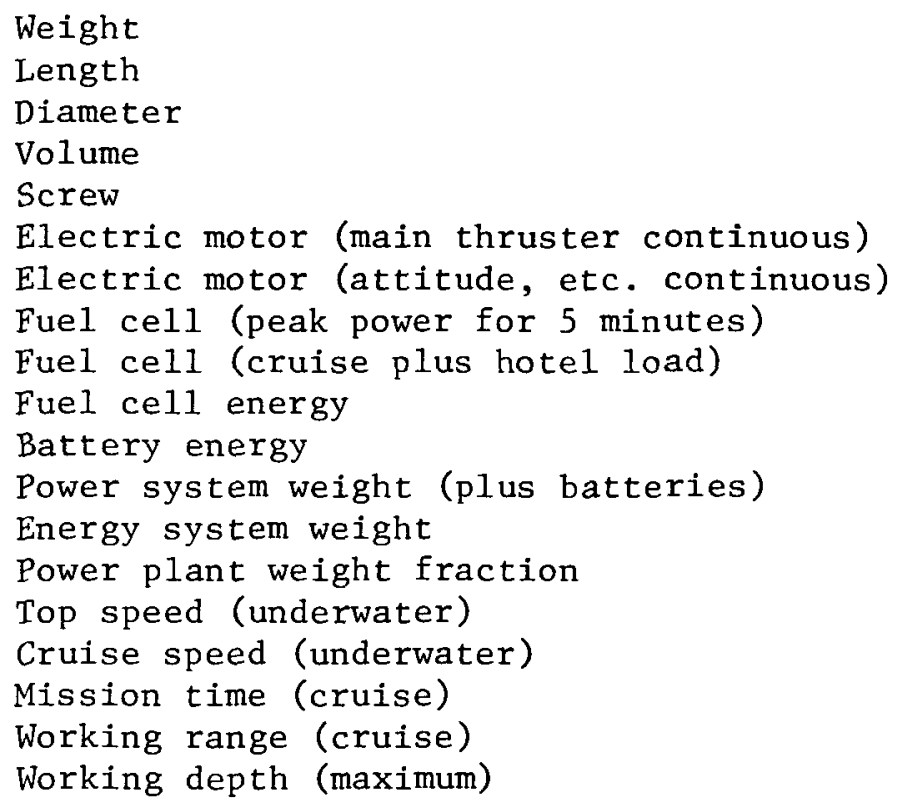

$50,000 \mathrm{~kg}$

$16.0 \mathrm{~m}$

$2.2 \mathrm{~m}$

$48.8 \mathrm{~m}^{3}$

Single

$30 \mathrm{~kW}$ (35 kW peak)

$30 \mathrm{~kW}$ (35 kW peak)

$140 \mathrm{~kW}$

$30 \mathrm{~kW}$

$4065 \mathrm{kWh}$

$58 \mathrm{kWh}$

$5120 \mathrm{~kg}$

$4880 \mathrm{~kg}$

.2

$14.8 \mathrm{~km} / \mathrm{h}$ (8 knots)

$11.1 \mathrm{~km} / \mathrm{h}$ (6 knots)

$135 \mathrm{~h}$

$750 \mathrm{~km}$ (405 n.m.)

$1060 \mathrm{~m}(3500 \mathrm{ft})$

\section{LIMITATIONS}

The treatment included little basis for comparison with other systems.

High Power Fuel Cells for Undersea Applications; C. E. Heath, et al.

\section{RESULTS}

A description of advanced, low weight, low volume fuel cells developed jointly by Alsthom and Exxon was provided. Their performance was evaluated for undersea applications requiring 0.5 to $100 \mathrm{~kW}$ power.

\section{CONCLUSIONS}

Based on their demonstrated high specific power and energy densities, Alsthom/Exxon hydrazine hydrogen peroxide generators appear to have a strong advantage over alternate systems for moderate and high power missions, $0.5-100 \mathrm{~kW}$, when the power demand, without recharge, is greater than ten mns. These systems maintain their advantage up to 500 hrs of continuous drain.

\section{LIMITATIONS}

No cost information; applications are described in general but no specific information is provided. 
Fuel Cell Power Plant for Deep Submergence Vehicles; R. A. Sanderson, et al.

RESULTS

A power system (PL 15A) consisting of a fuel cell power plant in its containment vessel, gas-storage tanks for $\mathrm{H}_{2}, \mathrm{O}_{2} \& \mathrm{H}_{2} \mathrm{O}$, and a control system were installed in a deep submergence vehicle. The design of the system and its operating characteristics are described.

DC Voltage $\quad 100 \mathrm{~V}$ @ $38 \mathrm{~kW}$

$114 \mathrm{~V} @ 20 \mathrm{~kW}$

$136 \mathrm{~V} @ 0 \mathrm{~kW}$

The power plant delivers $250 \mathrm{kWh}$ total energy for a 36-hour mission (93 W/hr/1b).

\section{CONCLUSIONS}

Undersea vehicles for research and recovery operations at extreme depth have established the need for a propulsion power source with higher energy storage/unit weight. This power plant, designated Powercel ISA, when supplied with gaseous hydrogen and oxygen stored at high pressure, will deliver three times the energy density of the best batteries in service today.

\section{LIMITATIONS}

Costs were not considered. The improvement in the energy/unit weight ratio offered by a fuel cell power system may be accompanied by a decrease in the energy/unit volume ratio.

Power Supplies for Telecommunications in Remote Areas; A. Haböck, F. Schmalzl.

\section{RESULTS}

Fuel cells are compared to other power sources for remote telecommunication applications. Some of the characteristics and advantages of fuel cells are described. A modular $7 \mathrm{~kW}$ fuel cell generating system was tested. Its output voltage was $53.8 \mathrm{X}$ its output current $140.5 \mathrm{~A}$ and its efficiency 51.2 percent.

\section{CONCLUSIONS}

The falling cost of fuel cells which is to be expected as a result of intensive development activities in many countries, and the ever increasing cost of supplying conventional generators with fuel will make fuel cells competitive for most installations in the near future. 


\section{LIMITATIONS}

The conclusion is based on expected future developments that may not be accomplished. Costs were not considered.

Assessment of Phosphoric Acid Fuel Cells for Vehicular Power Systems (United Technology Power Systems).

\section{RESULTS}

The potential application of fuel cells in vehicles is described. Goals are established and present fuel cell performance as well as advanced (future design) cell's performance are compared to these goals.

The fuel cell systems are described in some detail including cost, weight and volume breakdown by individual components. The steps required to achieve the advanced fuel cell system are outlined.

\section{CONCLUSIONS}

The fuel cell is a promising option for development of electric vehicles. Near-term technology can be used for heavier, lower performance vehicles such as buses and vans. Advanced designs will be suitable for passenger vehicles.

\section{LIMITATIONS}

Costs are based on large $(100,000$ units/year) production rates.

Feasibility Study of SPE Fuel Cell Power Plants for Automotive Applications; General Electric.

\section{RESULTS}

A study of the technicầ1 and economic viability of a vehicular power plant based on indirect methanol solid Polymer Electrolyte fuel cell stack was made. The power system is described in good detail, including weight, dimensions, and material of construction for each component. Cost of construction for the power plant is estimated based on various annual production rates.

\begin{tabular}{lrrr} 
& \multicolumn{3}{c}{ Systems Per Year } \\
\cline { 2 - 4 } & 1,000 & 10,000 & 100,000 \\
Reactor Stack Cost (1981 \$) & 4,758 & 3,289 & 2,817 \\
Balance of Power Plant & $\frac{695}{5,453}$ & $\frac{516}{3,805}$ & $\frac{457}{3,274}$ \\
Total System & 5,453
\end{tabular}




\section{CONCLUSIONS}

The SPE fuel cell power plant can meet all of the performance requirements for a compact passenger car. The cost of the system becomes feasible at high production rates.

Fuel Cells for Electric Vehicles; K. W. Kordesch, Union Carbide Corp.

\section{RESULTS}

The potential application of a fuel cell in vehicles is examined and compared to electric vehicles using rechargeable batteries. Requirements are listed for several important applications.

The fuel cell types that can potentially be used are described with reference to advantages. and disadvantages of each type for specific applications. Some experimental vehicles with hydrogen fuel cells are described. The idea of using secondary, batteries for peak power output thus reducing the size and cost of the fuel cell unit is mentioned.

\section{CONCLUSIONS}

The outlook for the utilization of fuel cells in vehicular applications is good if cost of electrodes can be reduced.

Prospects and Scientific Problems of the Utilization of Methods of Direct Electric Power Generation from Chemical Fuels (Fuel Cells); N. S. Lidorenko \& G. F. Muchnik.

\section{RESULTS}

A general examination of the prospects of utilizing fuel cells in various applications. These applications include most vehicular power systems and stationary power generating systems. Some of the general advantages of fuel cells are described. Power requirements for all potential applications are described (in general), e.g.

\section{A. Vehicular}

1. Powering private cars

2. Power for mass trans. facilities

$6-300 \mathrm{~kW}$

3. Long-range sea-going cargo ships

$40-740 \mathrm{~kW}$

4. Ferries, tankers, barges, etc. $<75,000 \mathrm{~kW}$

for inland routes

5. Carts, loaders, tractors

6. Electricity for trans. facilities

7. Portable devices 


\section{B. Stationary}
8. Energy Systems (Emergency)
hundreds of watts to hundreds of $\mathrm{kW}$
9. Smal1 power supplied for buoys, probes, etc.
10. Household applicances power supply

$\operatorname{cosTS}$

Capital

Operating
$\$ 10,000-20,000 / \mathrm{kW}$ (10-100 times that of diese1)
0.5 times that of diese 1

\section{CONCLUSIONS}

Fuel cell applications may become feasible if capital cost can be substantially reduced.

\section{LIMITATIONS}

Very general paper, mostly qualitative descriptions are provided.

Materials for Energy Conversion and Storage; B. C. Tofield.

\section{RESULTS}

Various options are described for the utilization of fuel cells in power generating facilities. Some of the problems in the development of fuel cells are described. The schematic diagrams for two potential fuel cell applications in power plants are included. The cost of fuel cel1s $(1981)$ is about $\$ 10,000 / \mathrm{kW}$. Cost required for the first production unit is about $\$ 1,500 / \mathrm{kW}$ and the cost required for mass production is about $\$ 350 / \mathrm{kW}$. The required lifetime for a commercial unit is about 40,000 hours. The estimated lifetime for the fuel cell unit studied in this paper ( 4.8 MWFGG1) is 6,700 hours.

\section{CONCLUSIONS}

The cost of fuel cells is very high and their lifetime shorter than required for commercialization. 
Future Fuels and Engines for Railroad Locomotives Volume II: Technical Document; S. G. Liddle et al.

\section{RESULTS}

The potential application of various engines, including fuel ce11s, to railroad locomotives is examined. The performance requirements of a locomotive engine are described, the characteristics of a fuel cell engine are estimated and the feasibility of such application assessed. An economic analysis is also included.

\section{CONCLUSIONS}

This life-cycle cost analysis has shown that locomotives with costs substantially lower than the present diesel-electric units are economically possible. The coal-fired locomotives are the most attractive with lifecycle costs about half that of the present locomotives. The adiabatic diesel using synthetic hydrocarbons is also an attractive candidate engine with life-cycle costs about 30\% less than the present engines.

The cost of developing these new locomotives is not known since the cost could and should be shared with other programs using the same technology. However, the magnitude of the savings possible as compared to the present engines is great enough to justify the development of at least one new engine.

Ocean Engineering Power Systems - M.I.T. Feb. 19\%4; A. D. Carmichael.

\section{RESULTS}

Very theoretical. Includes theory of thermodynamics and describes various energy sources including fuel cells. The final chapter of the thesis is of most interest. It describes the requirements of the applications of power in the ocean and relates them to the characteristics of the power plants and the energy sources. The power requirements of submersibles, underwater habitats, buoys, offshore drilling rigs, offshore oil production rigs, ocean mining and desalination are outlined for each system component and related to operating conditions.

\section{CONCLUSIONS}

None. The text is to be used as teaching material for undergraduates. Can be used as source document. 
Fuel Cel1s for Transportation Applications - Jan 1 - Dec 31. 1981;

J. R. Huff, Los Alamos, N.M.

\section{RESULTS}

Consumer vehicle requirements are described based on the body and chassis of the General Motors X car. Each vehicle is designed to cruise at $60 \mathrm{mph}$ and have top speed of $70 \mathrm{mph}$.

\section{Target Fuel Cell System Characteristics} $(20 \mathrm{~kW}, 96 \mathrm{~V}$ Nomina1)

\begin{tabular}{lcc} 
& $\begin{array}{c}\text { Low-Power } \\
\text { Density }\end{array}$ & $\begin{array}{c}\text { High-Power } \\
\text { Density }\end{array}$ \\
\cline { 2 - 3 } Weight (1b) & 680 & 366 \\
Volume (ft3) & 12 & 9.3 \\
Start-up time (min) & 15 & 15 \\
Operating point (V/cell) & 6 & 0.5 \\
Power Density (W/ft 2 ) & 90 & 219 \\
Peak Power (kW) & 66 & 27 \\
Battery weight (1b) & 264 & 264
\end{tabular}

The performance of phosphoric acid electrolyte fuel cells, solid polymer electrolyte fuel cells, and super acid electrolyte fuel cells is also described. The projected cost for commercially produced fuel cells is $\$ 150-250 / \mathrm{kW}$.

\section{CONCLUSIONS}

The preliminary designs of PAFC and SPE fuel cell systems that are unique to vehicular applications strongly support the fechnical feasibility of using fuel cells for transport applications. Projected production costs for 100,000 units/year fall in the range of $\$ 150-250 / \mathrm{kW}$ (1981 dollars) for both systems.

\section{LIMITATIONS}

High production rates are assumed and the cost seems to be lower than cost estimates from other sources. 
Fuel Cel1 Propulsion for Small Manned Submersibles; J. M. Haddock. RESULTS

Examines the applicability of fuel cell systems to small manned submersibles. Most of the document deals with the history of submerisbles and fuel cells. Three modern fuel cell systems for submarine use are examined in some detail, and the impact of replacing the leadacid battery system of a 24-ton submersible with a hydrogen-oxygen fuel cell is assessed.

The $15 \mathrm{~kW}, 100 \mathrm{kWh}$ system considered in this study provides more than twice the energy of present lead-acid battery systems, has much less weight and negative buoyancy impact, and can be replenished in much less time.

\section{CONCLUSIONS}

Although the fuel cell system would be more expensive in both capital and operating cost than lead-acid batteries, it does not seem unreasonable that the payback in terms of overall system availability would more than compensate for the expense.

\section{LIMITATIONS}

The cost analysis is very general and not very useful.

\section{A Closed Brayton Cycle Power Plant for Underwater Applications and} Comparison with a Fuel Ce11; H. Balukjian.

\section{RESULTS}

The applicability of a fuel cell is compared with a closed Brayton cycle power plant. Advantages offered by the fuel cell include:

A. has a high overall cycle efficiency and therefore less reactants are required for long missions;

B. has a direct supply for DC power when needed;

C. does not use fuel when under no-load standby conditions;

D. has high overload capability for short periods of time;

E. efficiency is higher at lower loads.

Disadvantages are:

A. life of only 1,000 to 2,000 hours; 
B. If $\mathrm{AC}$ power is needed an inverter is required which has low efficiency.

C. higher efficiency is achieved at expense of lower current density:

D. high initial development cost:

E. high specific weight (1bs/kW);

F. hazards of working with $\mathrm{H}_{2}$ and $\mathrm{O}_{2}$.

\section{CONCLUSIONS}

The $50 \mathrm{~kW}$ closed Brayton plant has definite advantages in applications for undersea missions in the medium power, medium endurance range. These advantages become even more outstanding for missions requiring higher power leve1 ( $200 \mathrm{~kW}$ and up) in the medium endurance range. The fuel cell, however, has outstanding advantages for applications in the medium power level, long endurance region.

\section{LIMITATIONS}

Costs were not considered. 


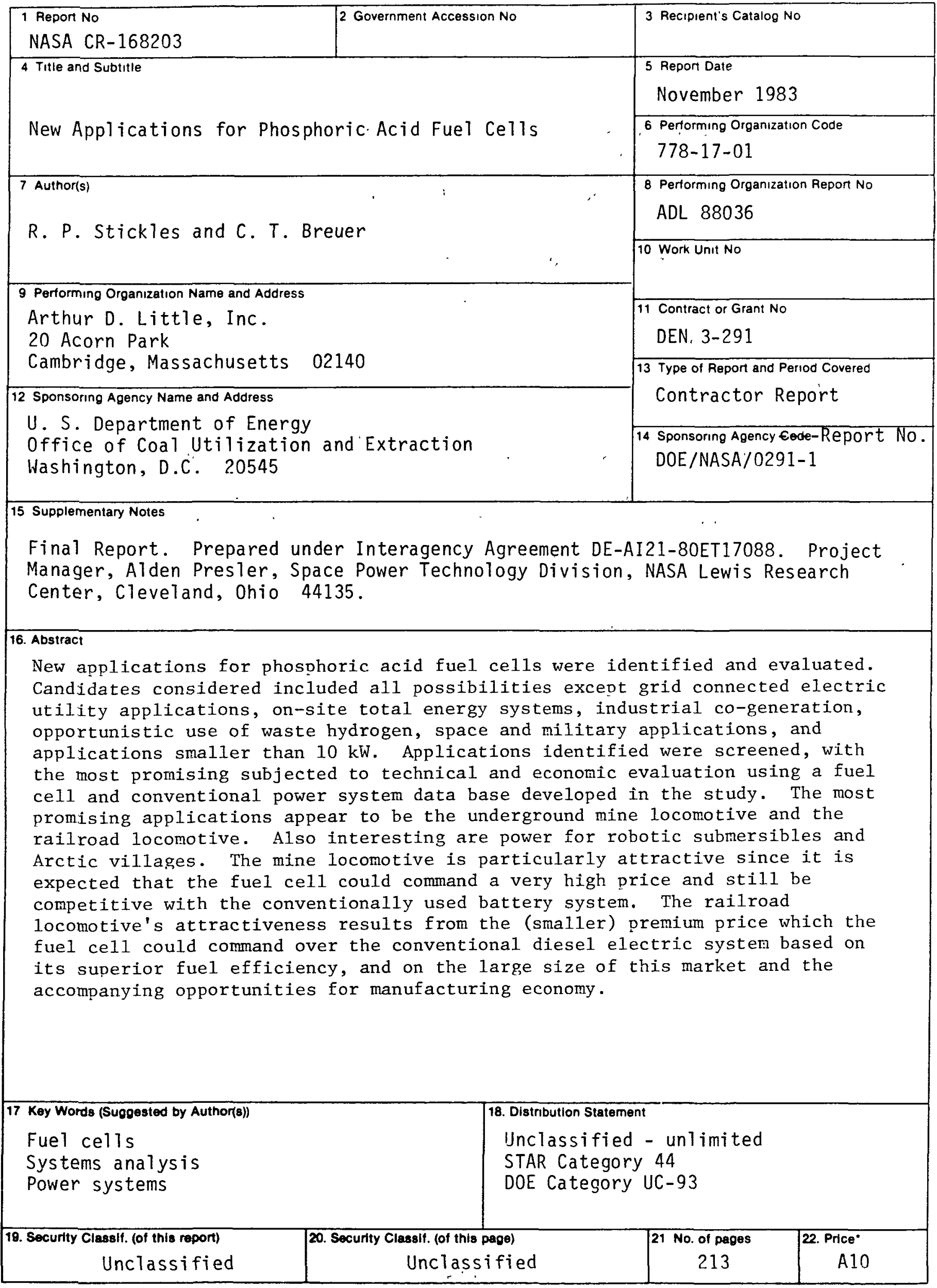

"For sale by the National Technical Information Service, Springfield, Virgina 22161 